Prepared in cooperation with the Water Replenishment District of Southern California

\title{
Estimating Spatially and Temporally Varying Recharge and Runoff from Precipitation and Urban Irrigation in the Los Angeles Basin, California
}

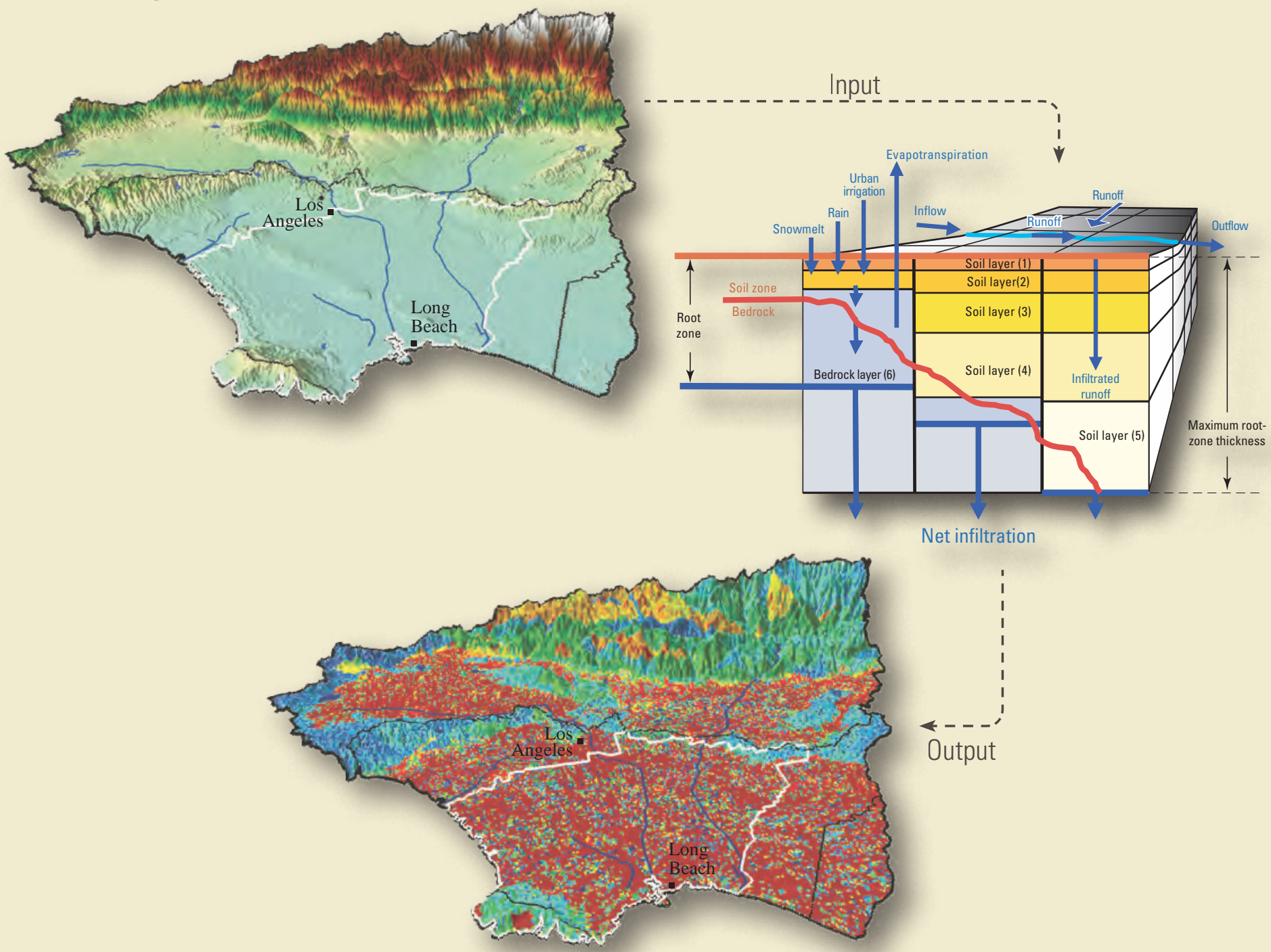

Scientific Investigations Report 2016-5068 

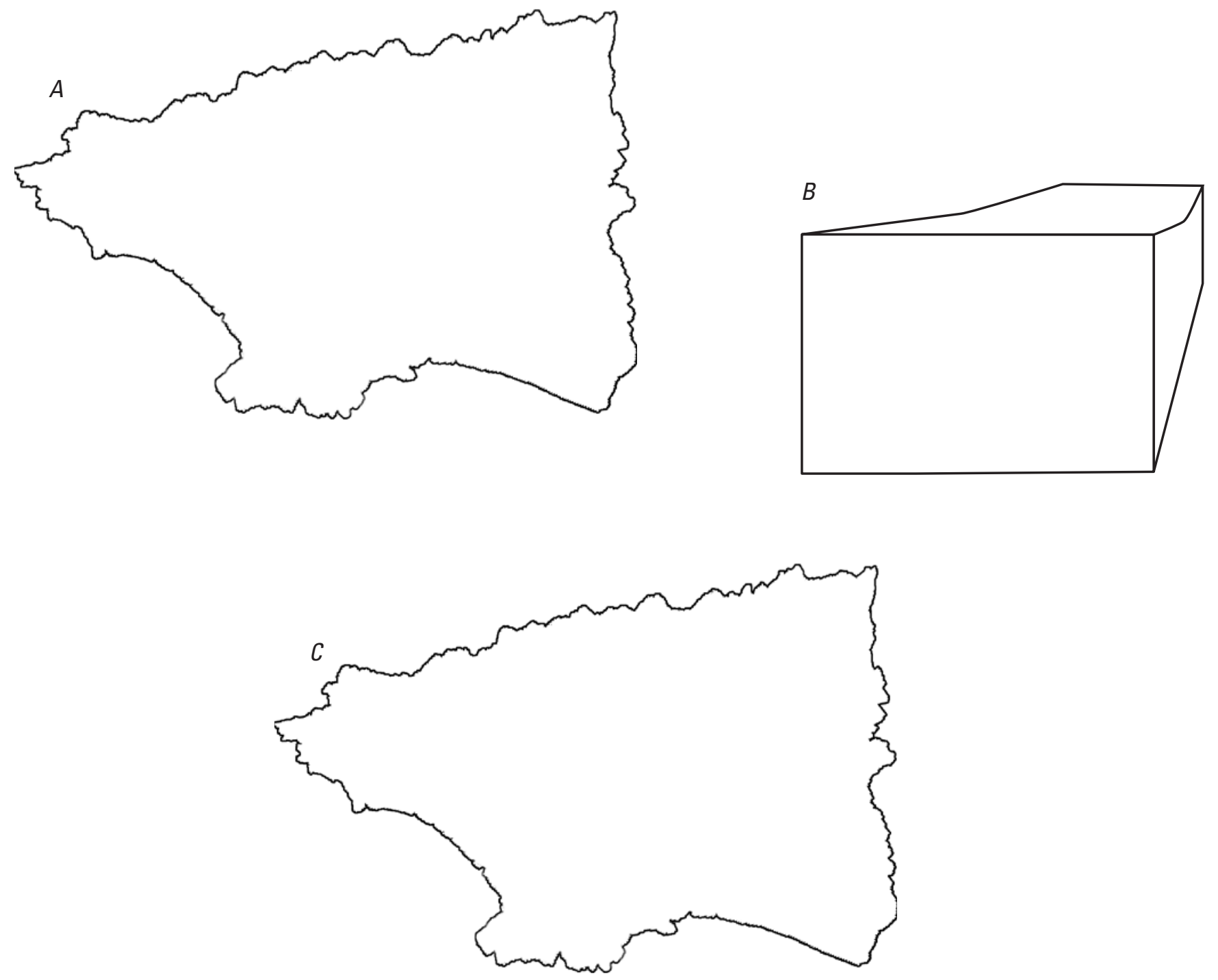

Cover. A, Los Angeles Basin watershed model (LABWM) elevation; $B$, Schematic showing the grid, water storage components, and flow processes used by the INFILv3 code to simulate the spatial distribution of flows by the Los Angeles Basin watershed model, California of the multi-layered root zone; $C$, Spatially distributed average annual recharge using the Los Angeles Basin watershed model, California. 


\section{Estimating Spatially and Temporally Varying Recharge and Runoff from Precipitation and Urban Irrigation in the Los Angeles Basin, California}

By Joseph A. Hevesi and Tyler D. Johnson

Prepared in cooperation with the Water Replenishment District of Southern California

Scientific Investigations Report 2016-5068 


\title{
U.S. Department of the Interior \\ SALLY JEWELL, Secretary
}

\author{
U.S. Geological Survey \\ Suzette M. Kimball, Director
}

U.S. Geological Survey, Reston, Virginia: 2016

For more information on the USGS - the Federal source for science about the Earth, its natural and living resources, natural hazards, and the environment-visit http://www.usgs.gov or call 1-888-ASK-USGS.

For an overview of USGS information products, including maps, imagery, and publications, visit http://www.usgs.gov/pubprod/.

Any use of trade, firm, or product names is for descriptive purposes only and does not imply endorsement by the U.S. Government.

Although this information product, for the most part, is in the public domain, it also may contain copyrighted materials as noted in the text. Permission to reproduce copyrighted items must be secured from the copyright owner.

Suggested citation:

Hevesi, J.A., and Johnson, T.D., 2016, Estimating spatially and temporally varying recharge and runoff from precipitation and urban irrigation in the Los Angeles Basin, California: U.S. Geological Survey Scientific Investigations Report 2016-5068, 192 p., http://dx.doi.org/10.3133/sir20165068.

ISSN 2328-0328 (online) 


\section{Acknowledgments}

The authors would like to acknowledge the support of the Water Replenishment District of Southern California who cooperatively funded this study.

The authors would like to also acknowledge several individuals who contributed to the technical content of this study, including technical reviewers John C. Risely (U.S. Geological Survey, Oregon Water Science Center) and Allen H. Christensen (California Water Science Center, CAWSC), surface-water specialist reviewer Kara M. Watson (New Jersey Water Science Center), and program chief reviewers Claudia Faunt and Debra S. Curry (CAWSC). 


\section{Contents}

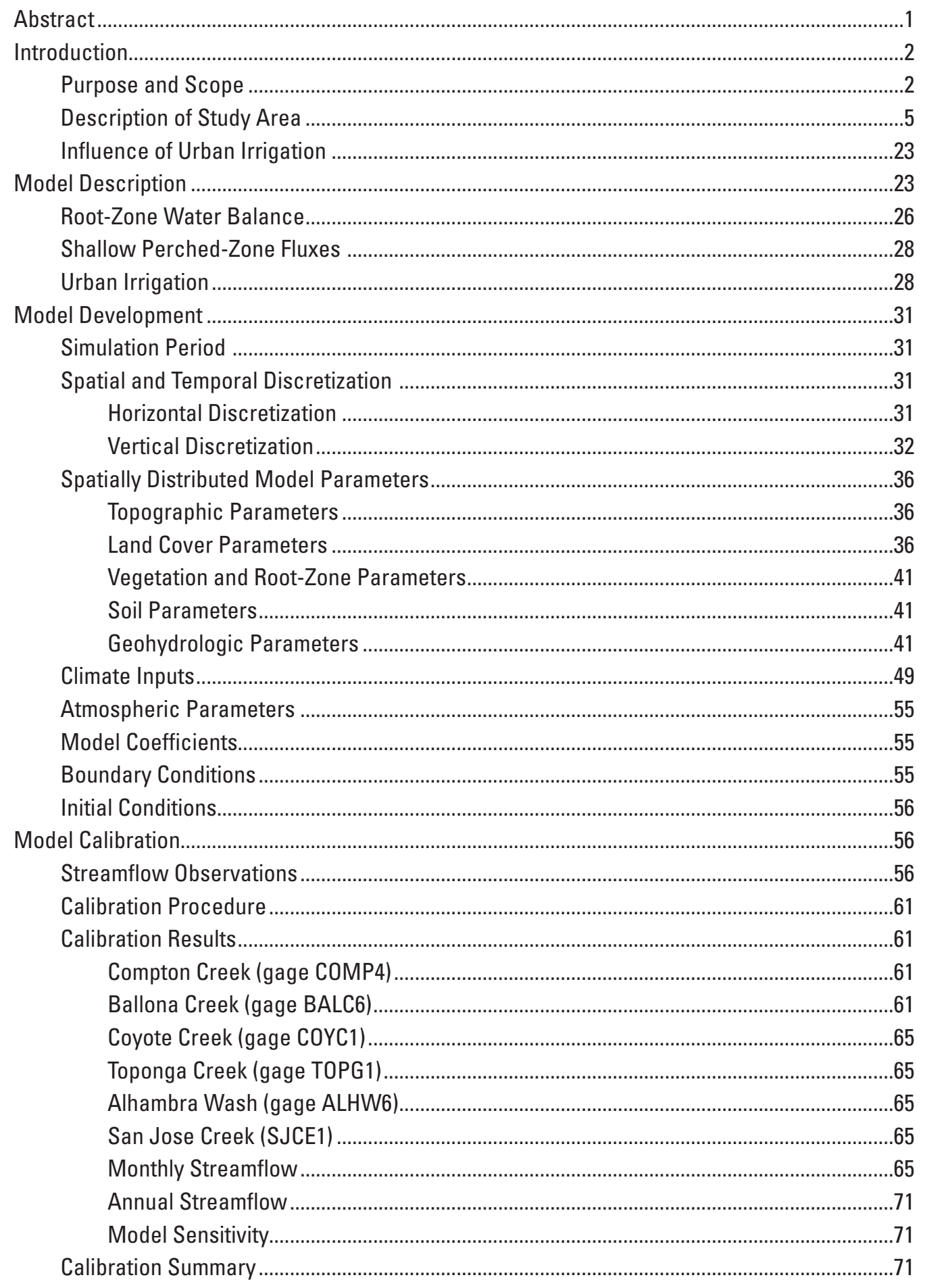




\section{Contents-Continued}

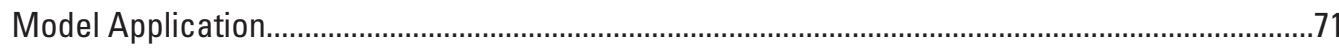

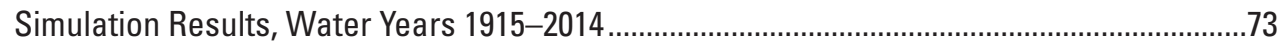

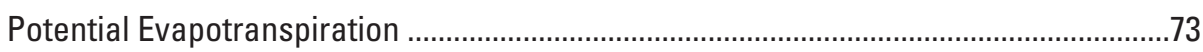

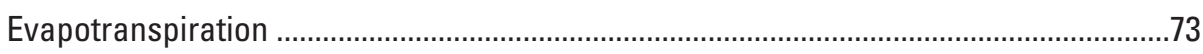

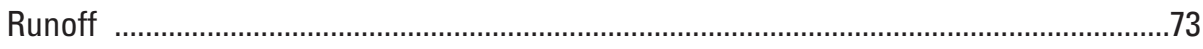

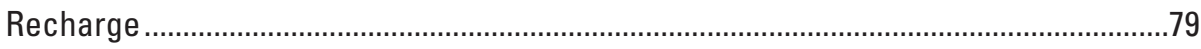

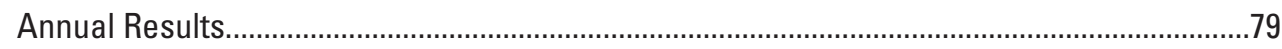

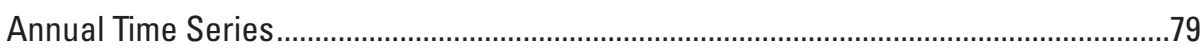

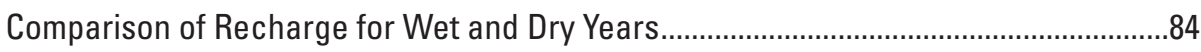

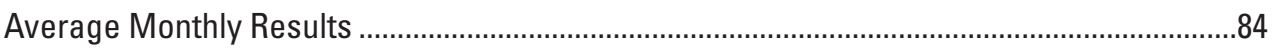

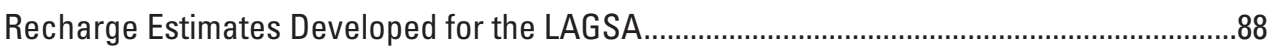

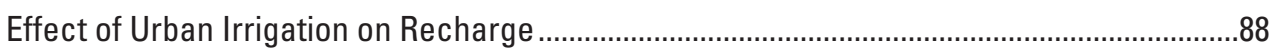

Comparison with Previous Recharge Estimates ..................................................................101

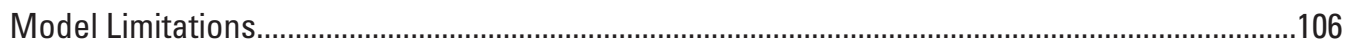

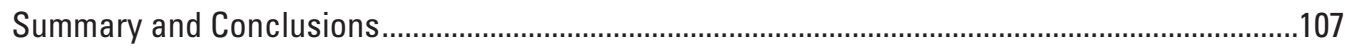

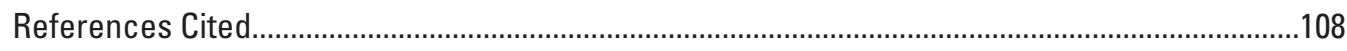

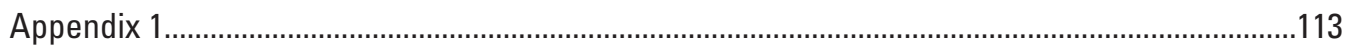

Appendix 2

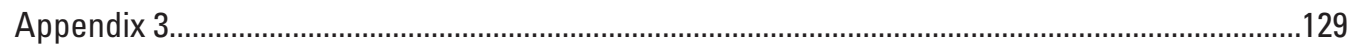

\section{Figures}

1. Maps showing the Los Angeles Basin watershed model area, southern California: $A$, Los Angeles groundwater basins and related study areas; $B$, major surfacewater drainages.....

2. Map showing land cover and land use for the Los Angeles Basin watershed model area, southern California region, California

3. Graphs showing average monthly values estimated for water years 1915-2014 for the Los Angeles Basin watershed model area, California, for $A$, precipitation; and $B$, maximum and minimum daily air temperature

4. Map showing average annual precipitation estimated for water years 1915-2014 for the Los Angeles Basin watershed model, California.

5. Map showing average air temperature estimated for water years 1915-2014 for the Los Angeles Basin watershed model, California

6. Schematics showing the grid, water storage components, and flow processes used by the INFILv3 code to simulate the spatial distribution of flows by the Los Angeles Basin watershed model, California: $A$, the multi-layered root zone; $B$, the perched zone

7. Time-series plot of the average water delivery to 1,795 single-family residential homes in the San Fernando Valley, Los Angeles Basin watershed model, California 


\section{Figures-Continued}

8. Maps showing the grid-cell flow-routing network, Los Angeles Basin watershed model, California: $A$, National Hydrography Data streams and Los Angeles County storm drains used to define the $D-8$ grid cell routing network; $B$, modeled streamlines as indicated by the number of upstream cells.

9. Map showing the twelve INFILv3 subdomains included in the Los Angeles Basin watershed model, California

10. Map showing average land-surface slope, Los Angeles Basin watershed model, California

11. Map showing average land-surface aspect, Los Angeles Basin watershed model, California

12. Map showing the percentage of impervious area, Los Angeles Basin watershed model, California .....

13. Map showing percentage of forest-canopy cover, Los Angeles Basin watershed model, California

14. Map showing vegetation type, Los Angeles Basin watershed model, California ...........42

15. Map showing soil type, Los Angeles Basin watershed model, California ........................44

16. Map showing rock types used as input for the Los Angeles Basin watershed model, California ..

17. Map showing estimated soil thickness, Los Angeles Basin watershed model, California

18. Map showing estimated thickness of bedrock-layer 6, Los Angeles Basin watershed model, California

19. Map showing estimated root-zone storage capacity, Los Angeles Basin watershed model, California.

20. Map showing spatially distributed average January precipitation and climate stations with daily precipitation records used in the Los Angeles Basin watershed model, California.

21. Map showing spatially distributed average January minimum daily air temperature and climate stations with daily air-temperature records used in the Los Angeles Basin watershed model, California.

22. Map showing average snowfall estimated for water years 1915-2014 by using the Los Angeles Basin watershed model, California...

23. Map showing average annual estimated urban irrigation, Los Angeles Basin watershed model, California.

24. Graph showing average quarterly irrigation for 11 subdomains, Los Angeles Basin watershed model, California.

25. Map showing six streamflow-gaging stations used for model calibration, Los Angeles Basin watershed model, California. 


\section{Figures-Continued}

26. Graphs showing comparison of simulated and measured streamflow at gage COMP4, Los Angeles Basin watershed model, California: $A$, daily; $B$, monthly; $C$, annual.

27. Graphs showing comparison of simulated and measured streamflow at gage BALC6, Los Angeles Basin watershed model, California: $A$, daily; $B$, monthly; $C$, annual

28. Graphs showing comparison of simulated and measured streamflow at gage COYC1, Los Angeles Basin watershed model, California: $A$, daily; $B$, monthly; $C$, annual

29. Graphs showing comparison of simulated and measured streamflow at gage TOPG1, Los Angeles Basin watershed model, California: $A$, daily; $B$, monthly; $C$, annual.

30. Graphs showing comparison of simulated and measured streamflow at gage ALHW6, Los Angeles Basin watershed model, California: $A$, daily; $B$, monthly; $C$, annual.

31. Graphs showing comparison of simulated and measured streamflow at gage SJCE1, Los Angeles Basin watershed model, California: $A$, daily; $B$, monthly; $C$, annual.

32. Scatterplots of simulated against measured monthly streamflow, Los Angeles Basin watershed model, California, at gage $A$, BALC6; $B$, COMP4; $C$, COYC1; $D$, TOPG1; E, ALHW6; F, SJCE1

33. Scatterplots of simulated against measured annual streamflow at six gages used for model calibration, Los Angeles Basin watershed model, California: $A$, normal scale; $B$, log-scale

34. Map showing average annual potential evapotranspiration simulated for water years 1915-2014 by using the Los Angeles Basin watershed model, California.

35. Map showing spatially distributed average annual evapotranspiration simulated for water years 1915-2014 by using the Los Angeles Basin watershed model, California

36. Map showing simulated average streamflow for water years 1915-2014 by using the Los Angeles Basin watershed model, California.

37. Map showing spatially distributed average annual recharge simulated for water years 1915-2014 using the Los Angeles Basin watershed model, California. .80

38. Graphs showing annual simulation results for water years 1915-2014, Los Angeles Basin watershed model (LABWM), California: $A$, LABWM water-budget components; $B$, LABWM water-budget components as inflows and outflows; $C$, Los Angeles recharge-study area water-budget components; $D$, Los Angeles recharge-study area water-budget components as inflows and outflows; $E$, annual recharge for the LABWM domains; $F$, cumulative departure from mean annual recharge for the LABWM domains 


\section{Figures-Continued}

39. Maps showing simulated annual recharge, Los Angeles basin watershed model, California, for $A$, water year 2005; and $B$, water year 2007 ..

40. Graphs showing average basin-wide monthly simulation results for water years 1915-2014, Los Angeles Basin watershed model, California: $A$, water-budget components; $B$, urban irrigation and recharge; $C$, inflows and outflows.

41. Map showing recharge areas for the Los Angeles groundwater study area, Los Angeles Basin watershed model, California.

42. Graphs showing annual and average monthly recharge simulated for the Los Angeles groundwater study area, Los Angeles Basin watershed model, California: $A$, direct and mountain-front recharge components; $B, 5$-year average annual direct recharge for groundwater basins; $C, 5$-year average annual recharge for mountain-front areas; $D$, average monthly recharge rate.

43. Map showing difference in simulation results, irrigated minus non-irrigated evapotranspiration for the Los Angeles recharge-study area, water years 1915-2014, Los Angeles Basin watershed model, California

44. Map showing difference in simulation results, irrigated minus non-irrigated change in root-zone storage for the Los Angeles recharge-study area, water years 1915-2014, Los Angeles Basin watershed model, California .....

45. Map showing the percentage difference for irrigated minus non-irrigated simulation simulated runoff for the Los Angeles recharge-study area, water years 1915-2014, Los Angeles Basin watershed model, California ..

46. Map showing difference in results, irrigated minus non-irrigated simulated recharge for the Los Angeles recharge-study area, water years 1914-2015, Los Angeles Basin watershed model, California.

47. Graphs showing comparison of average monthly simulated recharge, Los Angeles Basin watershed model, California: $A$, average monthly recharge without irrigation; $B$, average monthly difference in recharge with and without urban irrigation; $C$, average monthly percentage increase in recharge with irrigation.

48. Graphs showing comparison of simulation results for subdomains by using a range of urban irrigation estimates, Los Angeles Basin watershed model, California: $A$, average 1915-2014 recharge; $B$, average 1915-2014 evapotranspiration

49. Graphs showing comparison of simulation results for subdomains by using a range of urban irrigation estimates, Los Angeles Basin watershed model, California: $A$, percentage of contribution of urban irrigation to recharge; $B$, percentage of contribution of urban irrigation estimates to evapotranspiration

50. Map showing internal and contributing recharge areas used for previous recharge estimates, Los Angeles Basin watershed model, California.

51. Graphs showing comparison of annual results from a previous study and results from using the Los Angeles Basin watershed model, California, for $A$, precipitation; and $B$, recharge

52. Graph showing comparison of recoverable water with effective precipitation obtained with previous studies and with the Los Angeles Basin watershed model, California 


\section{Tables}

1. Land-cover and land-use distributions for the Los Angeles Basin watershed model, California

2. Climate stations and records used for estimating daily precipitation and maximum and minimum air temperature, Los Angeles Basin watershed model, California..............8

3. Average irrigation rates, in millimeters, estimated for 1,795 high-density singlefamily residential homes by using the minimum-month method, Los Angeles Basin watershed model, California.

4. Top 10 land-use classes (by area) of the San Fernando Valley, Los Angeles Basin watershed model, California.

5. Table of vegetation parameters (layers 1-6), Los Angeles Basin watershed model, California .

6. Table of soil parameters, model layers 1-5, Los Angeles Basin watershed model, California

7. Geologic parameters (layers 6-7), Los Angeles Basin watershed model, California ....47

8. Atmospheric parameters, Los Angeles basin watershed model, California ....................56

9. Streamflow-gaging stations and streamflow records used for model calibration, Los Angeles Basin watershed model, California..............................................................60

10. Summary of model calibration results, Los Angeles Basin watershed model, California

11. Summary of average inflows, outflows, and changes in storage for total model area and model subdomains, water years 1915-2014, Los Angeles Basin watershed model, California

12. Summary of average inflows, outflows, and changes in storage for the Los Angeles groundwater basins and Los Angeles groundwater study area, water years 1915-2014, Los Angeles Basin watershed model, California

13. Comparison of evapotranspiration and change in root-zone water-storage simulation results with and without urban irrigation, water years 1915-2014, Los Angeles Basin watershed model, California.

14. Comparison of recharge and streamflow simulation results with and without urban irrigation for water years 1915-2014, Los Angeles Basin watershed model, California .

1-1. Los Angeles Basin watershed model..........................................................................114

2-1. Los Angeles recharge study area.......................................................................122

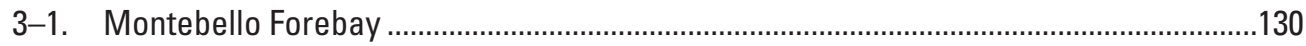

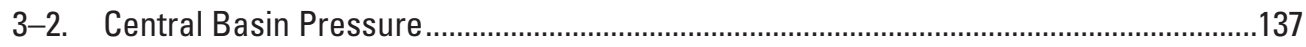

3-3. West Coast Basin ......................................................................................................... 144

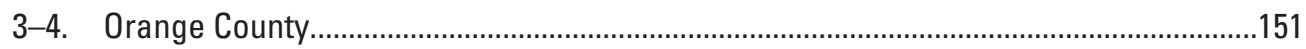

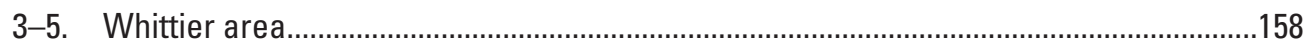

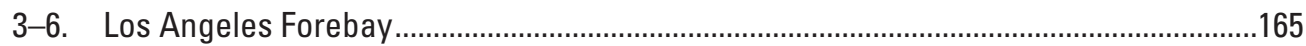

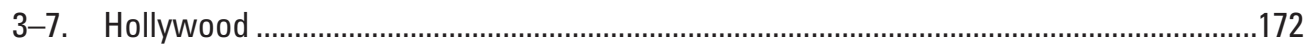

3-8. Santa Monica ................................................................................................................ 179

3-9. Los Angeles groundwater study area ........................................................................186 


\section{Conversion Factors}

International System of Units to U.S. customary units

\begin{tabular}{|c|c|c|}
\hline Multiply & By & To obtain \\
\hline \multicolumn{3}{|c|}{ Length } \\
\hline millimeter (mm) & 0.03937 & inch (in.) \\
\hline meter (m) & 3.281 & foot (ft) \\
\hline \multicolumn{3}{|c|}{ Area } \\
\hline square kilometer $\left(\mathrm{km}^{2}\right)$ & 247.1 & acre \\
\hline hectare (ha) & 0.003861 & square mile $\left(\mathrm{mi}^{2}\right)$ \\
\hline square kilometer $\left(\mathrm{km}^{2}\right)$ & 0.3861 & square mile $\left(\mathrm{mi}^{2}\right)$ \\
\hline \multicolumn{3}{|c|}{ Volume } \\
\hline cubic kilometer $\left(\mathrm{km}^{3}\right)$ & 0.2399 & cubic mile $\left(\mathrm{mi}^{3}\right)$ \\
\hline cubic meter $\left(\mathrm{m}^{3}\right)$ & 0.0008107 & acre-foot (acre-ft) \\
\hline hectare meter (ha-m) & 8.107 & acre-foot (acre-ft) \\
\hline \multicolumn{3}{|c|}{ Flow rate } \\
\hline cubic meter per second $\left(\mathrm{m}^{3} / \mathrm{s}\right)$ & 35.31 & cubic foot per second ( $\left.\mathrm{ft}^{3} / \mathrm{s}\right)$ \\
\hline hectare meter per year (ha-m/yr) & 8.1103 & acre-foot per year (acre-ft/yr) \\
\hline millimeter per year (mm/yr) & 0.03937 & inch per year (in/yr) \\
\hline
\end{tabular}

Temperature in degrees Celsius $\left({ }^{\circ} \mathrm{C}\right)$ may be converted to degrees Fahrenheit $\left({ }^{\circ} \mathrm{F}\right)$ as ${ }^{\circ} \mathrm{F}=\left(1.8 \times{ }^{\circ} \mathrm{C}\right)+32$.

\section{Datum}

Vertical coordinate information is referenced to North American Vertical Datum of 1988 (NAVD 88).

Horizontal coordinate information is referenced to the North American Datum of 1983 (NAD 83).

Elevation, as used in this report, refers to distance above the vertical datum. 


\section{Abbreviations}

$\begin{array}{ll}\text { BCM } & \text { Basin Characterization Model } \\ \text { DOD } & \text { U.S. Department of Defense } \\ \text { EPA } & \text { U.S. Environmental Protection Agency } \\ \text { ET } & \text { Evapotranspiration } \\ \text { GIS } & \text { Geographic Information System } \\ \text { LABWM } & \text { Los Angeles Basin watershed model } \\ \text { LACDWP } & \text { Los Angeles County Department of Power and Water } \\ \text { LAGSA } & \text { Los Angeles groundwater study area } \\ \text { NED } & \text { National Elevation Data } \\ \text { NSME } & \text { Nash-Sutcliffe model efficiency } \\ \text { PAEE } & \text { percent average estimation error } \\ \text { PET } & \text { potential evapotranspiration } \\ \text { PRISM } & \text { Parameter-elevation Regressions on Independent Slopes Model } \\ \text { PRMS } & \text { Precipitation Runoff Modeling System } \\ \text { STATSGO } & \text { State Soil Geographic Database } \\ \text { SWB } & \text { Soil Water Balance Model } \\ \text { USGS } & \text { U.S. Geological Survey } \\ \text { WRD } & \text { Water Replenishment District } \\ & \end{array}$


This page intentionally left blank 


\title{
Estimating Spatially and Temporally Varying Recharge and Runoff from Precipitation and Urban Irrigation in the Los Angeles Basin, California
}

\author{
By Joseph A. Hevesi and Tyler D. Johnson
}

\section{Abstract}

A daily precipitation-runoff model, referred to as the Los Angeles Basin watershed model (LABWM), was used to estimate recharge and runoff for a 5,047 square kilometer study area that included the greater Los Angeles area and all surface-water drainages potentially contributing recharge to a 1,450 square kilometer groundwater-study area underlying the greater Los Angeles area, referred to as the Los Angeles groundwater-study area. The recharge estimates for the Los Angeles groundwater-study area included spatially distributed recharge in response to the infiltration of precipitation, runoff, and urban irrigation, as well as mountain-front recharge from surface-water drainages bordering the groundwater-study area. The recharge and runoff estimates incorporated a new method for estimating urban irrigation, consisting of residential and commercial landscape watering, based on land use and the percentage of pervious land area.

The LABWM used a 201.17-meter gridded discretization of the study area to represent spatially distributed climate and watershed characteristics affecting the surface and shallow sub-surface hydrology for the Los Angeles groundwater study area. Climate data from a local network of 201 monitoring sites and published maps of 30-year-average monthly precipitation and maximum and minimum air temperature were used to develop the climate inputs for the LABWM. Published maps of land use, land cover, soils, vegetation, and surficial geology were used to represent the physical characteristics of the LABWM area. The LABWM was calibrated to available streamflow records at six streamflowgaging stations.

Model results for a 100-year target-simulation period, from water years 1915 through 2014, were used to quantify and evaluate the spatial and temporal variability of waterbudget components, including evapotranspiration (ET), recharge, and runoff. The largest outflow of water from the LABWM was ET; the 100-year average ET rate of 362 millimeters per year $(\mathrm{mm} / \mathrm{yr})$ accounted for 66 percent of the combined water inflow of $551 \mathrm{~mm} / \mathrm{yr}$, including
$488 \mathrm{~mm} / \mathrm{yr}$ from precipitation and $63 \mathrm{~mm} / \mathrm{yr}$ from urban irrigation. The simulated ET rate varied from a minimum of $0 \mathrm{~mm} / \mathrm{yr}$ for impervious areas to high values of more than $1,000 \mathrm{~mm} / \mathrm{yr}$ for many areas, including the south-facing slopes of the San Gabriel Mountains, stream channels underlain by permeable soils and thick root zones, and pervious locations receiving inflows both from urban irrigation and surface water. Runoff was the next largest outflow, averaging $145 \mathrm{~mm} / \mathrm{yr}$ for the 100-year period, or 26 percent of the combined precipitation and urban-irrigation inflow. Recharge averaged $45 \mathrm{~mm} / \mathrm{yr}$, or about 8 percent of the combined inflow from precipitation and urban irrigation.

Simulation results indicated that recharge in response to urban irrigation was an important component of spatially distributed recharge, contributing an average of 56 percent of the total recharge to the eight LABWM subdomains containing the Los Angeles groundwater study area. The 100 -year average recharge rate for the eight subdomains was $41 \mathrm{~mm} / \mathrm{yr}$, or 8,473 hectare-meters per year (ha-m/yr), with urban irrigation included in the simulation compared to a recharge rate of $18 \mathrm{~mm} / \mathrm{yr}$, or 3,741 ha-m/yr, with urban irrigation excluded. In contrast to recharge, the effect of urban irrigation on runoff was slight; runoff was 72,667 ha-m/yr with urban irrigation included compared to 72,618 ha-m/yr with urban irrigation excluded, an increase of only $48 \mathrm{ha}-\mathrm{m} / \mathrm{yr}$ (about 0.1 percent).

Simulation results also indicated that potential recharge from hilly drainages outside of, but bordering and tributary to, the lower-lying area of the Los Angeles groundwater study area, in this study referred to as mountain-front recharge, could provide an important contribution to the total recharge for the groundwater basins. The time-averaged recharge rate was similar to the combined direct and mountain-front recharge components estimated in a previous study and used as input for a calibrated groundwater model. The annual (water year) recharge estimates simulated in this study, however, indicated much greater year-to-year variability, which was dependent on year-to-year variability in the magnitude and distribution of daily precipitation, compared to the previous estimates. 


\section{Introduction}

The Water Replenishment District (WRD) of Southern California is the groundwater-management agency responsible for the availability of a safe and reliable supply of groundwater for a 109,773 hectare (ha) management area in southern coastal Los Angeles County (Water Replenishment District of Southern California, 2013; fig. 1). Through the 20th century, historical development of groundwater basins in the greater Los Angeles area, including the WRD management area, caused large water-level declines and induced seawater intrusion (Reichard and others, 2003). To mitigate water-level declines and seawater intrusion, numerous groundwatermanagement activities were implemented in the latter part of the 20th century, including increased surface-water spreading for induced recharge, construction of groundwater-injection barriers, increased delivery of imported water, and increased use of reclaimed water (Reichard and others, 2003).

In order to improve the scientific basis for the watermanagement activities of the WRD, the U.S. Geological Survey (USGS), in cooperation with the WRD, developed a groundwater-flow and optimization model for a 167,316-ha study area in southern Los Angeles County, including most of the WRD management area (Reichard and others, 2003; fig. 1A). As part of the development of the groundwater model, the land area in the groundwater-study area was partitioned into seven groundwater basins on the basis of hydrogeologic studies and well data: (1) Central Basin Pressure, (2) Hollywood, (3) Los Angeles (LA) Forebay, (4) Montebello Forebay, (5) Santa Monica, (6) West Coast Basin, and (7) Whittier Area (Reichard and others, 2003). The boundaries of the seven groundwater basins were modified during subsequent groundwater studies by the USGS, done in cooperation with the WRD (Claudia Faunt and Scott Paulinski, U.S. Geological Survey, written commun., June 2015). In addition to these modifications an area referred to as the Orange County groundwater basin was added to the groundwater study area because the area of interest for groundwater studies was extended southeastward into northwestern Orange County (Claudia Faunt and Scott Paulinski, U.S. Geological Survey, written commun., June 2015). The 149,968-ha area defined by these eight groundwater basins is referred to as the Los Angeles groundwater study area (LAGSA; fig. 1A).

Recharge is an important component of the hydrologic system of the LAGSA that needs to be defined as part of the development of groundwater-flow models and to quantify the water budget. Recharge to the LAGSA includes natural and anthropogenic (artificially induced) components. Natural recharge includes recharge from infiltration of precipitation (rainfall and snowmelt) and surface-water runoff. Recharge from infiltration of streamflow in the larger channels is limited because most of the larger stream channels were lined with concrete (Reichard and others, 2003). The Los Angeles River was lined along its entire extent in the LAGSA, except just upstream from where it enters San Pedro Bay. The San Gabriel
River was lined, except in the upper parts of the Montebello Forebay and near the Alamitos Gap, and the Rio Hondo was lined its entire extent in the LAGSA.

For the 100-year period considered in this study, from water year 1915 through water year 2014, much of the recharge was anthropogenic. Anthropogenic recharge includes two types: (1) artificially induced or enhanced recharge from spreading grounds, retention basins, and injection wells, and (2) return flows from irrigation and leakage from water and sewer lines. A major source of anthropogenic, artificially induced recharge to the LAGSA is the diversion of storm runoff and imported water from the Rio Hondo and San Gabriel River stream channels to the spreading ponds next to the stream channels in the Whittier Narrows area along the northeastern boundary of the LAGSA, upstream from the Montebello Forebay (Reichard and others, 2003). A second important source of anthropogenic, artificially induced recharge is from injection wells in the western and southwestern parts of the LAGSA.

The LAGSA is hydraulically linked to three adjacent basins: the San Fernando Valley to the north, the San Gabriel Valley to the northeast, and the Orange County Basin to the southeast. In addition to these three adjacent basins, recharge from streams with unlined channels in smaller drainages along the periphery of the LAGSA could contribute to mountainfront recharge. In this study, mountain-front recharge to a groundwater basin refers to lateral inflows of groundwater that originates as recharge in surface-water drainages upstream from the groundwater basin and peripheral to the boundary of the groundwater basin. Peripheral drainages potentially contributing to recharge to the LAGSA are along the northern, northeastern, and southwestern boundary of the LAGSA (Reichard and others, 2003). For this study, the total area contributing recharge to the LAGSA, including the LAGSA and peripheral drainages bordering the LAGSA, is referred to as the Los Angeles recharge-study area (fig. 1).

\section{Purpose and Scope}

The purpose of this report is to document the development, calibration, and application of the Los Angeles Basin watershed model (LABWM). The primary purpose of the LABWM was to estimate spatially and temporally distributed recharge to the LAGSA in response to precipitation and runoff, as well as recharge in response to urban irrigation, by using a distributed-parameter, daily precipitation-runoff model called the LABWM. The LABWM was also used to quantify components of the water budget, including spatially and temporally distributed runoff in response to daily precipitation and urban irrigation. The LABWM was developed by using the INFILv3 watershed-modeling code (U.S. Geological Survey, 2008) with a modification to include quarterly estimates of urban-area landscape irrigation, added to the daily precipitation input as a spatially distributed daily urban irrigation rate. Application of the modified precipitationrunoff model allowed for the simulation of the natural 
$\boldsymbol{A}$

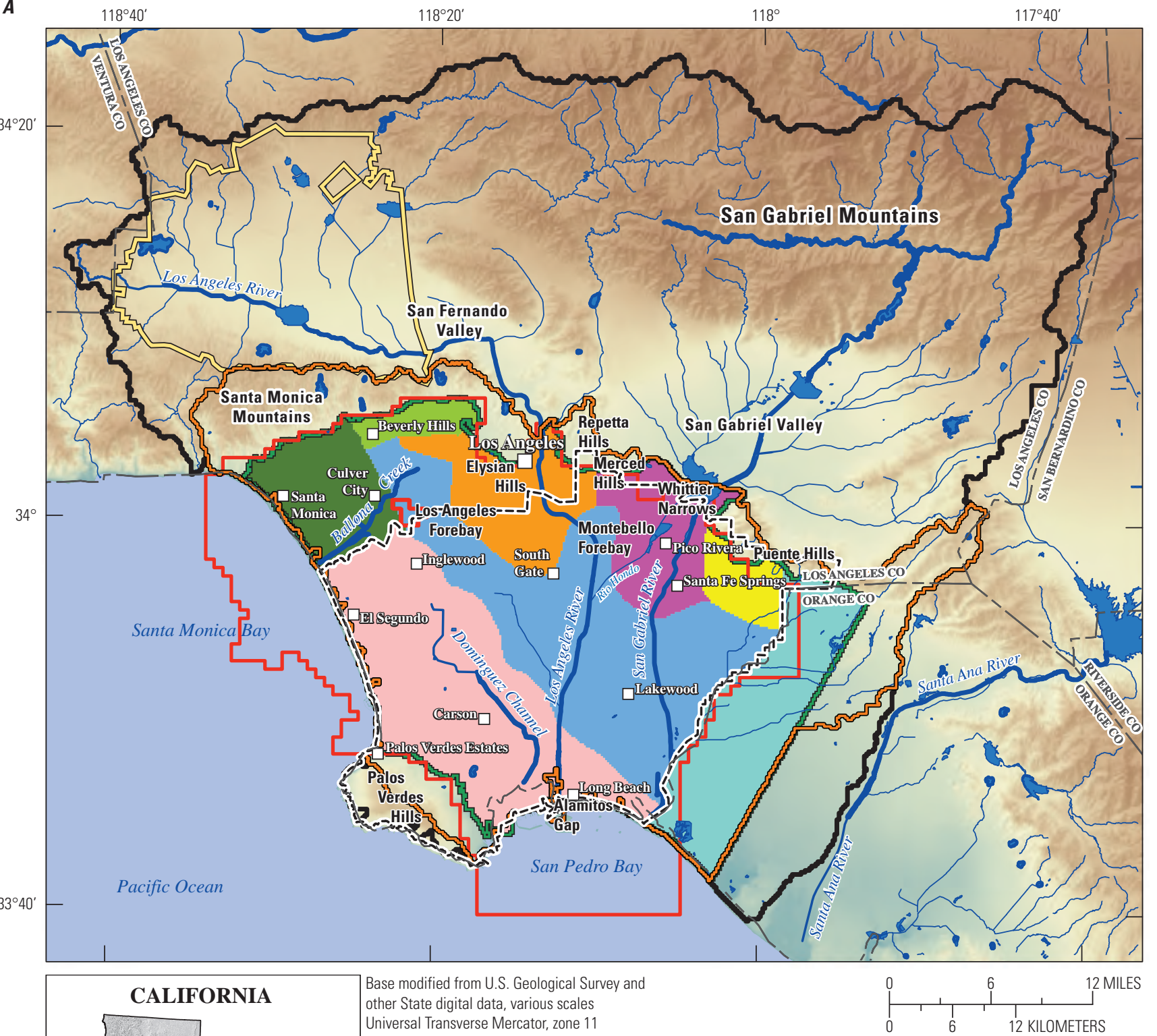

EXPLANATION

Los Angeles groundwater basins

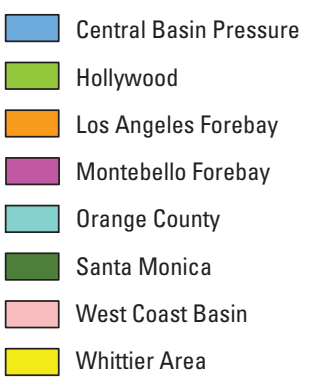

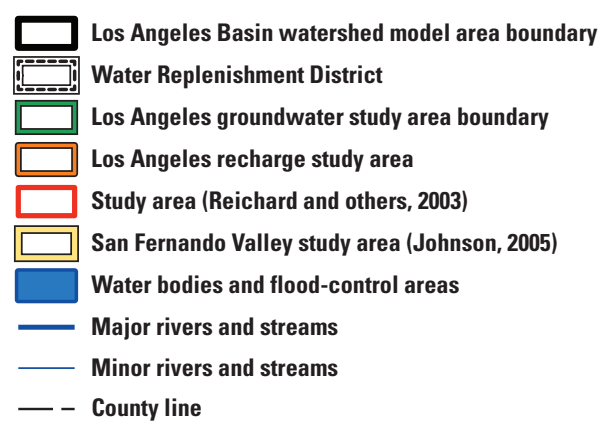

Figure 1. Los Angeles Basin watershed model (LABWM) area, southern California: $A$, Los Angeles groundwater basins and related study areas; $B$, major surface-water drainages. 
$B$

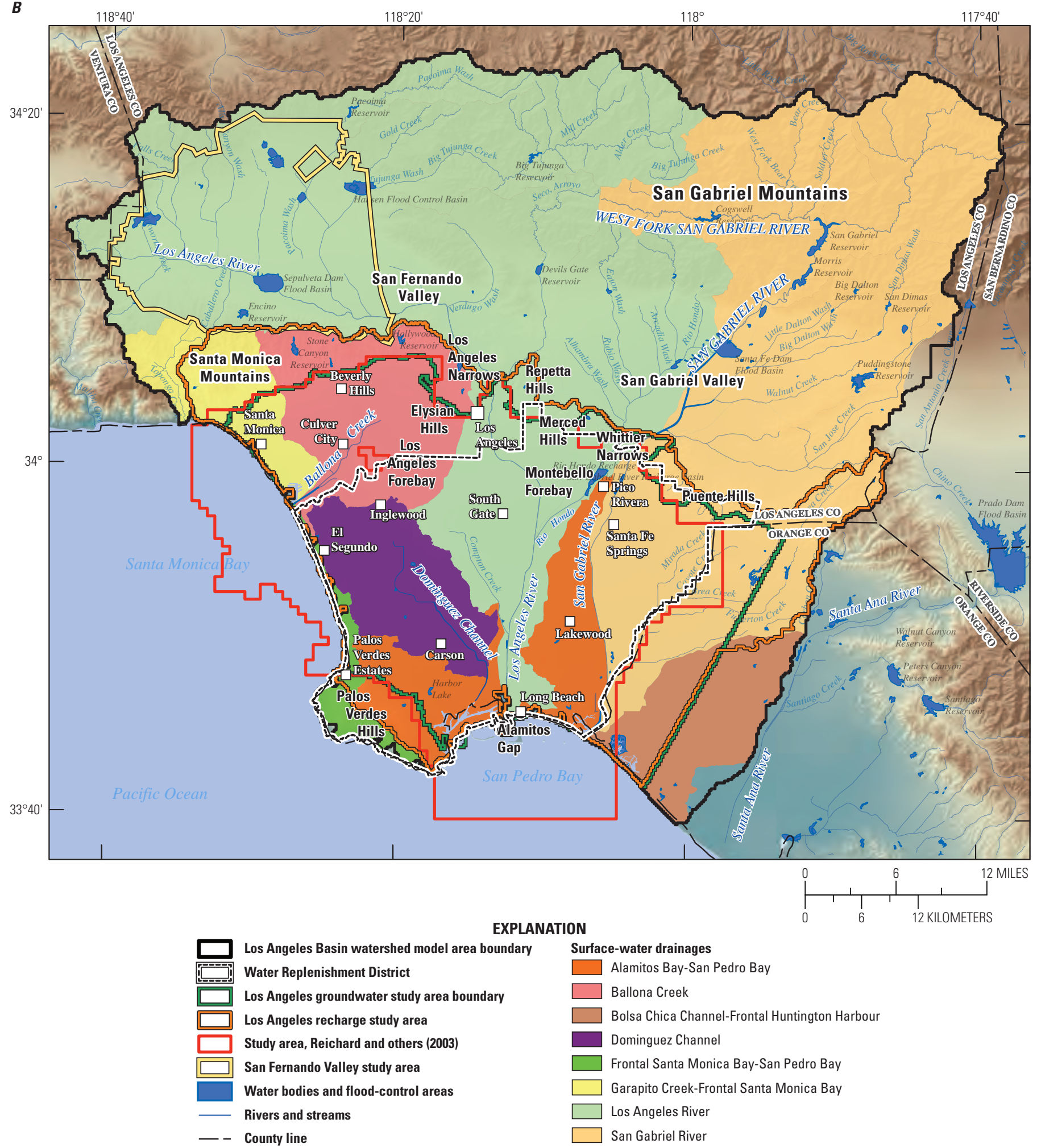

Figure 1. - Continued 
recharge component and the urban return flow component of anthropogenic recharge resulting from urban irrigation. A distributed-parameter model was used to improve the representation of spatial variability in natural recharge and recharge in response to urban irrigation. The precipitationrunoff model was applied by using the available climate data for a 110-year simulation period starting with water year 1905 and ending with water year 2014. The simulation period included a 10-year model-initialization period (water years 1905-14) and a 100-year target-simulation period (water years 1915-2014). The 100-year simulation period was used to evaluate the temporal variability of recharge and runoff in response to temporal variability in climate and to develop estimates of the long-term water budget.

This study accounts only for natural recharge in response to precipitation and runoff and anthropogenic recharge in response to urban landscape irrigation. Although induced recharge from retention basins, spreading grounds, and injection wells are significant sources of recharge for the LAGSA, these recharge sources are documented and quantified by the WRD of Southern California, and, therefore, did not require estimation or simulation as part of the ongoing groundwater flow modeling studies.

\section{Description of Study Area}

The study area for this report is defined by the boundary of the LABWM area (fig. 1). The LABWM area is 5,047 square kilometers $\left(\mathrm{km}^{2}\right)$, which includes most of southern Los Angeles County, the northwestern part of Orange County, a small area of westernmost San Bernardino County, and a small area of easternmost Ventura County. The LABWM area was defined on the basis of the need to include all surface-water drainages that have potential to contribute to natural recharge and runoff in response to climate as well as urban-irrigation induced recharge and runoff for the LAGSA.

The LABWM area is drained by three main rivers: (1) the Los Angeles River, with a drainage area of 2,142 $\mathrm{km}^{2}$; (2) the San Gabriel River, with a drainage area of $1,850 \mathrm{~km}^{2}$; and (3) Ballona Creek, with a drainage area of $340 \mathrm{~km}^{2}$ (fig. 1B). Additional drainages and hydrographic areas in the LABWM area include the Dominguez Channel drainage $\left(214 \mathrm{~km}^{2}\right)$, the Garapito Creek-frontal Santa Monica Bay hydrographic area $\left(334 \mathrm{~km}^{2}\right)$, the frontal Santa Monica Bay-San Pedro Bay hydrographic area $\left(301 \mathrm{~km}^{2}\right)$, the Alamitos Bay-San Pedro Bay hydrographic area $\left(428 \mathrm{~km}^{2}\right)$, and the Bolsa Chica Channel-Huntington Harbor hydrographic area $\left(330 \mathrm{~km}^{2}\right.$; fig. 1B). The upper Los Angeles River, which drains the San Fernando Valley to the north, enters the LAGSA through the Los Angeles Narrows. The San Gabriel River and Rio Hondo (a major tributary of the Los Angeles River), which drain the San Gabriel Mountains and the San Gabriel Valley to the northeast, both enter the LAGSA through the Whittier Narrows. The Santa Ana River, the largest drainage in the southern California region, runs along the southeastern boundary of the LABWM area. Most of the larger rivers in the
LABWM area are managed by flow diversions, reservoirs, and spreading grounds (Reichard and others, 2003). Natural stream channels exist primarily in the mountainous areas, whereas in the developed areas, most of the streamflow is routed through a system of engineered channels and storm drains.

Although the upper parts of the Los Angeles, San Gabriel River and Rio Hondo watersheds probably do not contribute much recharge to the LAGSA, these areas were included in LABWM area for completeness in terms of simulating the surface-water drainages potentially affecting the LAGSA. The larger model area allowed for a more comprehensive representation of the watershed areas potentially contributing recharge to the LAGSA, including areas outside of the area of the peripheral drainages included in the Los Angeles rechargestudy area (fig. 1). The inclusion of the complete watersheds for the Los Angeles River, the San Gabriel River, and the Rio Hondo, also incorporated the complete drainage areas upstream from some of the streamflow-gaging stations used for model calibration.

The LABWM area is bounded by the crest of the San Gabriel Mountains to the north, the Pacific Ocean to the west and south, Orange County to the southeast, and San Bernardino County to the east (fig. 1). The northeastern part of the LABWM area includes the more rugged terrain of the San Gabriel Mountains, with elevations ranging from 1,000 to 3,505 meters (m), and land cover consisting mostly of natural vegetation (fig. 2). The northwestern part of the LABWM area includes the rugged terrain of the Santa Monica Mountains, with elevations from 200 to $1,000 \mathrm{~m}$, and also includes land cover consisting primarily of natural vegetation. In contrast to the mountainous areas, low-lying areas in the LABWM area, including the Los Angeles coastal plain in the southern part (with elevations for most areas varying from sea level to $100 \mathrm{~m}$ ), the San Fernando Valley in the northwestern part (with elevations varying from 200 to $500 \mathrm{~m}$ ), and the San Gabriel Valley in the east-central part (with elevations varying from 70 to $350 \mathrm{~m}$ ), are generally highly urbanized areas (figs. 1, 2). Although agricultural land uses composed a large percentage of the developed-land areas within the LABWM area in the earlier 1900s, developed-land areas from the mid-1900s onward consist primarily of medium-tohigh density residential, commercial, and industrial land uses (Reichard and others, 2003). In more recent times (calendar year 2001), developed-land areas (including open space and low-, medium-, and high-density developed areas) covered $3,225 \mathrm{~km}^{2}$ in the LABWM area, or about 64 percent of the total land area (table 1). Compared to the LABWM area in 2001, the Los Angeles recharge-study area and the LAGSA had much greater percentages of land cover consisting of developed areas in 2001; developed-land areas covered 90 percent $\left(1,694 \mathrm{~km}^{2}\right)$ of the Los Angeles recharge-study area and 97 percent $\left(1,453 \mathrm{~km}^{2}\right)$ of the LAGSA (table 1). For all areas, the developed areas consisted mostly of medium-density developed land. Forested lands covered 7 percent $\left(344 \mathrm{~km}^{2}\right)$ of the LABWM area, compared to 1 percent $\left(17 \mathrm{~km}^{2}\right)$ for the Los Angeles recharge-study area and about 0 percent $\left(2 \mathrm{~km}^{2}\right)$ 


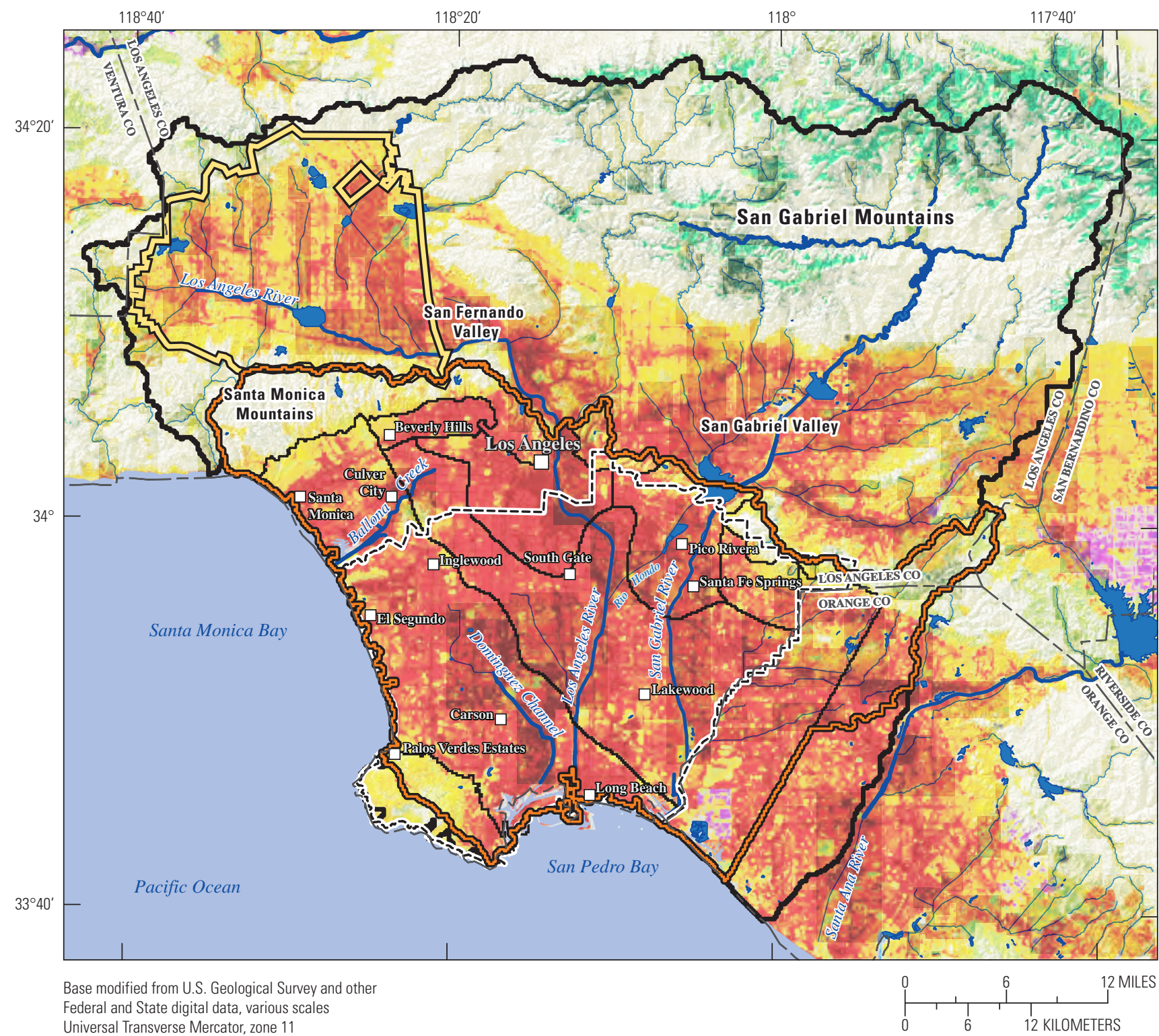

Universal Transverse Mercator, zone 11

North American Datum 1983

\section{EXPLANATION}

\begin{tabular}{l}
\multicolumn{1}{l}{ Dominant land-cover types (2001) } \\
\hline Ocean \\
Barren land \\
Cultivated crops \\
Deciduous forest \\
Developed, high intensity \\
\hline Developed, medium intensity \\
$\square$ Developed, low intensity \\
$\square$ Developed, open space
\end{tabular}

$\square$ Emergent herbaceous wetlands
Evergreen forest
$\square$ Grassland and herbaceous
$\square$ Mixed forest
$\square$ Open water
$\square$ Paster and hay
$\square$ Shrub and scrub
$\square$ Woody wetlands

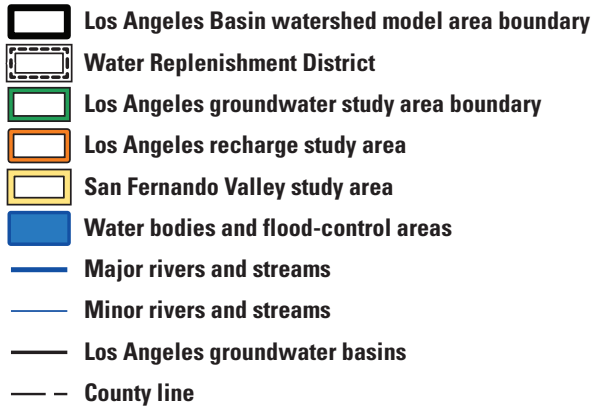

Figure 2. Land cover and land use for the Los Angeles Basin watershed model (LABWM) area, southern California region, California. 
Table 1. Land-cover and land-use distributions for the Los Angeles Basin watershed model (LABWM), California.

$\left[\mathrm{km}^{2}\right.$, square kilometer $]$

\begin{tabular}{|c|c|c|c|c|c|c|}
\hline \multirow{2}{*}{$\begin{array}{l}2001 \text { land cover } \\
\text { and land use }\end{array}$} & \multicolumn{2}{|c|}{$\begin{array}{c}\text { Los Angeles Basin } \\
\text { watershed model area }\end{array}$} & \multicolumn{2}{|c|}{$\begin{array}{c}\text { Los Angeles recharge } \\
\text { study area }\end{array}$} & \multicolumn{2}{|c|}{$\begin{array}{c}\text { Los Angeles groundwater } \\
\text { study area }\end{array}$} \\
\hline & $\begin{array}{l}\text { Area } \\
\left(\mathbf{k m}^{2}\right)\end{array}$ & $\begin{array}{l}\text { Total area } \\
\text { (percent) }\end{array}$ & $\begin{array}{l}\text { Area } \\
\left(\mathbf{k m}^{2}\right)\end{array}$ & $\begin{array}{c}\text { Total area } \\
\text { (percent) }\end{array}$ & $\begin{array}{l}\text { Area } \\
\left(\mathrm{km}^{2}\right)\end{array}$ & $\begin{array}{l}\text { Total area } \\
\text { (percent) }\end{array}$ \\
\hline Open water & 20 & 0 & 13 & 1 & 9 & 1 \\
\hline Developed, open space & 482 & 10 & 157 & 8 & 79 & 5 \\
\hline Developed, low intensity & 725 & 14 & 250 & 13 & 187 & 12 \\
\hline Developed, high intensity & 522 & 10 & 415 & 22 & 393 & 26 \\
\hline Barren land (rock/sand/clay) & 14 & 0 & 3 & 0 & 3 & 0 \\
\hline Deciduous forest & 0 & 0 & 0 & 0 & 0 & 0 \\
\hline Evergreen forest & 281 & 6 & 6 & 0 & 1 & 0 \\
\hline Pasture/hay & 2 & 0 & 0 & 0 & 0 & 0 \\
\hline Cultivated crops & 7 & 0 & 6 & 0 & 6 & 0 \\
\hline Woody wetlands & 5 & 0 & 1 & 0 & 1 & 0 \\
\hline Emergent herbaceous wetlands & 5 & 0 & 2 & 0 & 2 & 0 \\
\hline Total land cover & 5,048 & 100 & 1,887 & 100 & 1,500 & 100 \\
\hline Total developed land cover & 3,225 & 64 & 1,694 & 90 & 1,453 & 97 \\
\hline Total natural vegetation cover & 1,780 & 35 & 171 & 9 & 29 & 2 \\
\hline Natural forest cover & 344 & 7 & 17 & 1 & 2 & 0 \\
\hline
\end{tabular}

for the LAGSA. For the LABWM area and the Los Angeles recharge-study area, shrubland was the dominant natural vegetation cover in 2001, whereas grassland was the dominant natural vegetation for the LAGSA. For all areas, open water covered 1 percent or less of the land area in 2001.

Variations in the timing, frequency, amount, and spatial distribution of precipitation are important factors affecting the natural hydrologic system. Spatial and temporal variations in air temperature, as well as diurnal variations between maximum and minimum daily temperature, are also critical factors because air temperature affects the available energy for evapotranspiration and the type of precipitation (rain or snow). Higher elevations are generally colder and wetter compared to the low-lying coastal plane and interior valleys. Inland locations are generally hotter during the summer and colder during the winter compared to locations along the coastline.

Average monthly precipitation for the LABWM area was estimated for water years 1915-2014 by using a modified inverse-distance-squared spatial-interpolation method (Hevesi and Christensen, 2015; Flint and Martin, 2012) that incorporates the Parameter-elevation Regressions on Independent Slopes Model (PRISM) 30-year (1971-2000) normal precipitation map (Daly and others, 2004) and daily precipitation records from a network of 201 climate stations distributed throughout the LABWM area (table 2). PRISM accounts for various factors affecting the spatial distribution of precipitation, including topography, average storm track, and distance from moisture sources (Daly and others, 2004). The PRISM results are commonly used to develop climate inputs for watershed models (Hevesi and others, 2011; Flint and Martin, 2012; Woolfenden and Nishikawa, 2014; Hevesi and Christensen, 2015). The modified inverse-distancesquared spatial-interpolation method uses the PRISM estimates, available as 800-meter gridded national maps, and the 201 daily precipitation records to develop estimates of spatially distributed daily precipitation for the entire LABWM area (Hevesi and others, 2011; Woolfenden and Nishikawa, 2014; Hevesi and Christensen, 2015). The results indicated that precipitation falls primarily during the cooler months of October through May (fig. 3A). For most of the LABWM area, February was the wettest month, averaging 123 millimeters $(\mathrm{mm})$ for the entire LABWM area and varying from $287 \mathrm{~mm}$ for the wettest location, in the San Gabriel Mountains, to $70 \mathrm{~mm}$ for the driest, in the southern coastal part of the LABWM area. January and March were the second and third wettest months, respectively, with both months averaging more than $100 \mathrm{~mm}$ precipitation in the LABWM area. July was the driest month, averaging $0.6 \mathrm{~mm}$ for the entire LABWM area and ranging from $7.6 \mathrm{~mm}$ to $0 \mathrm{~mm}$ in the LABWM area. 


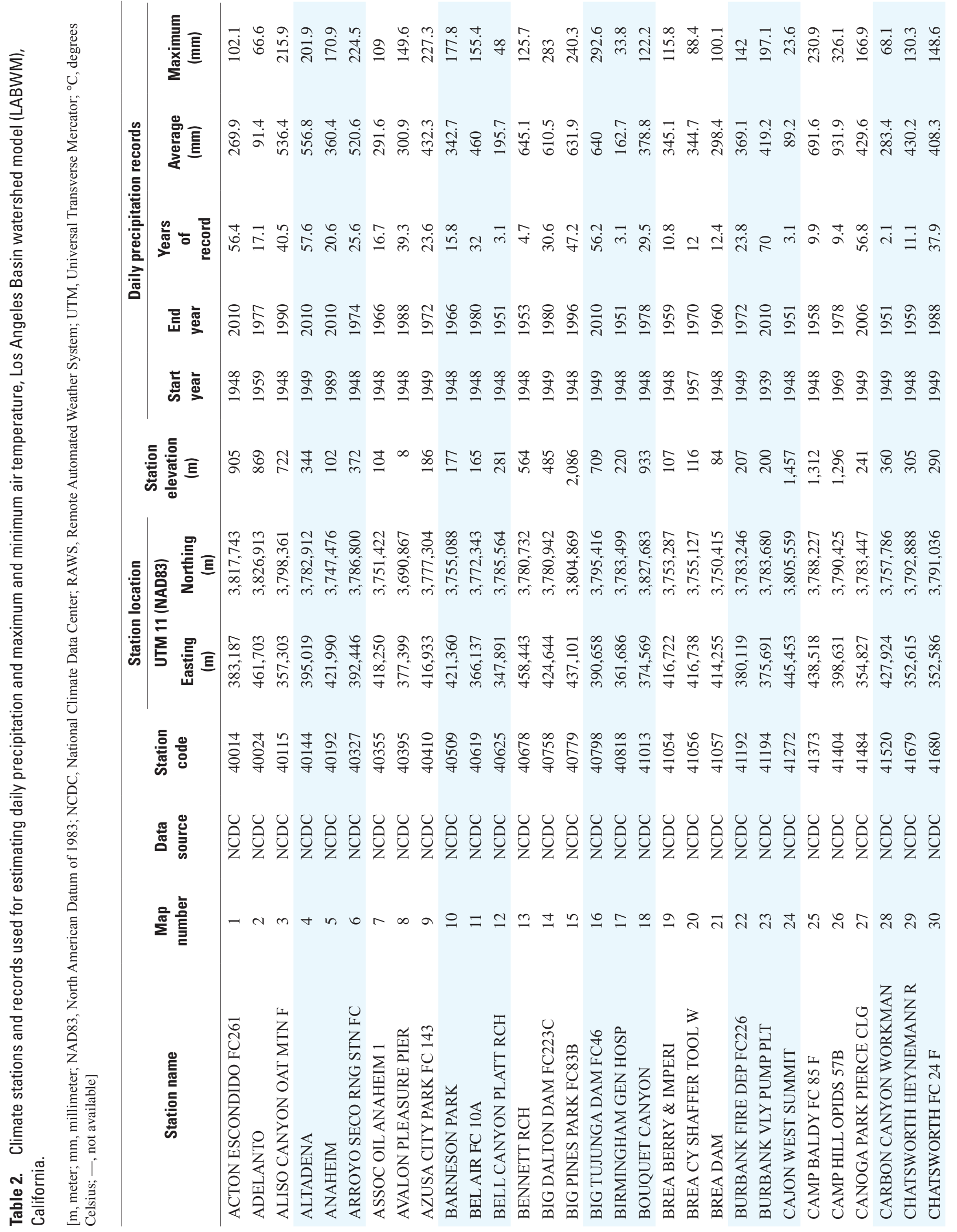




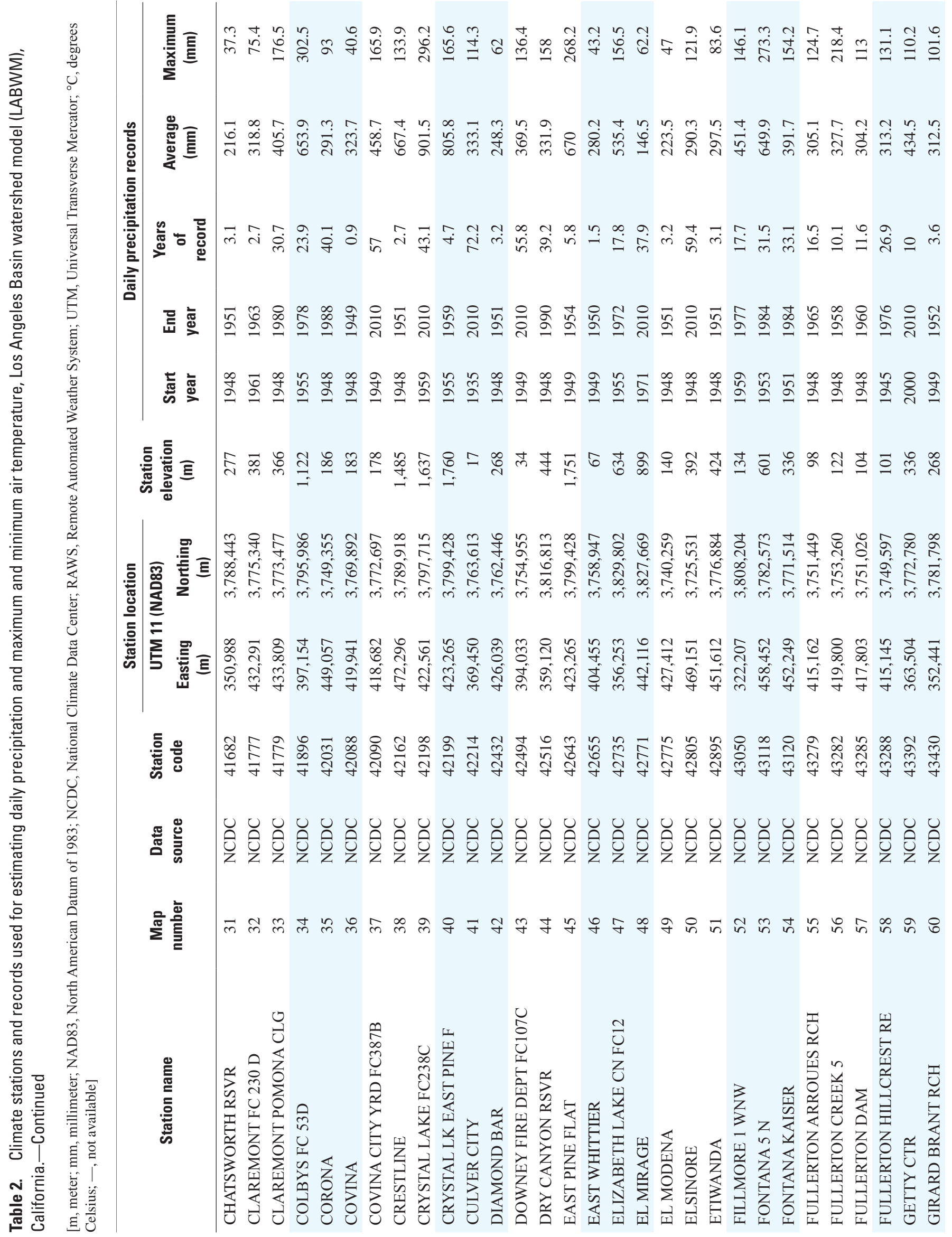




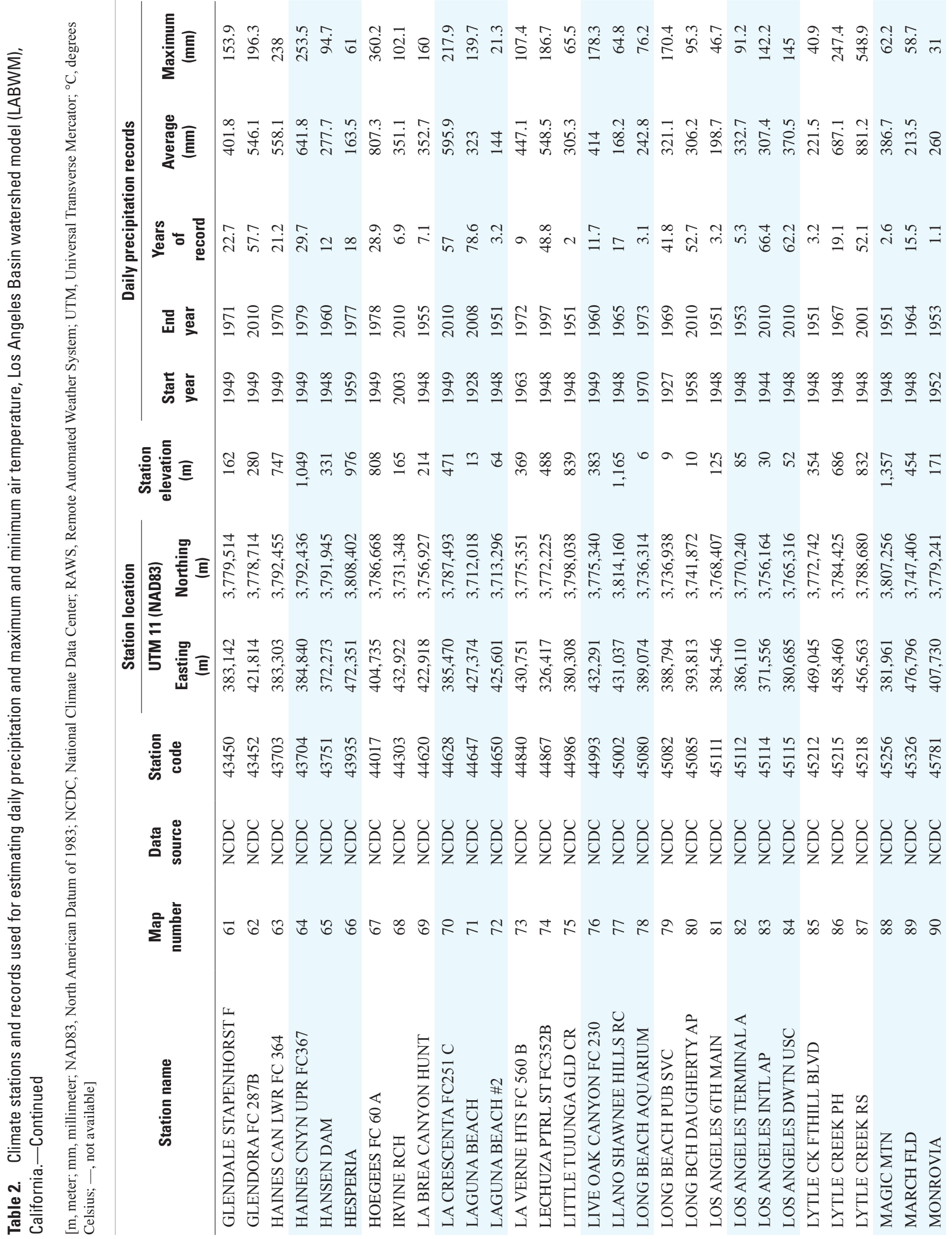




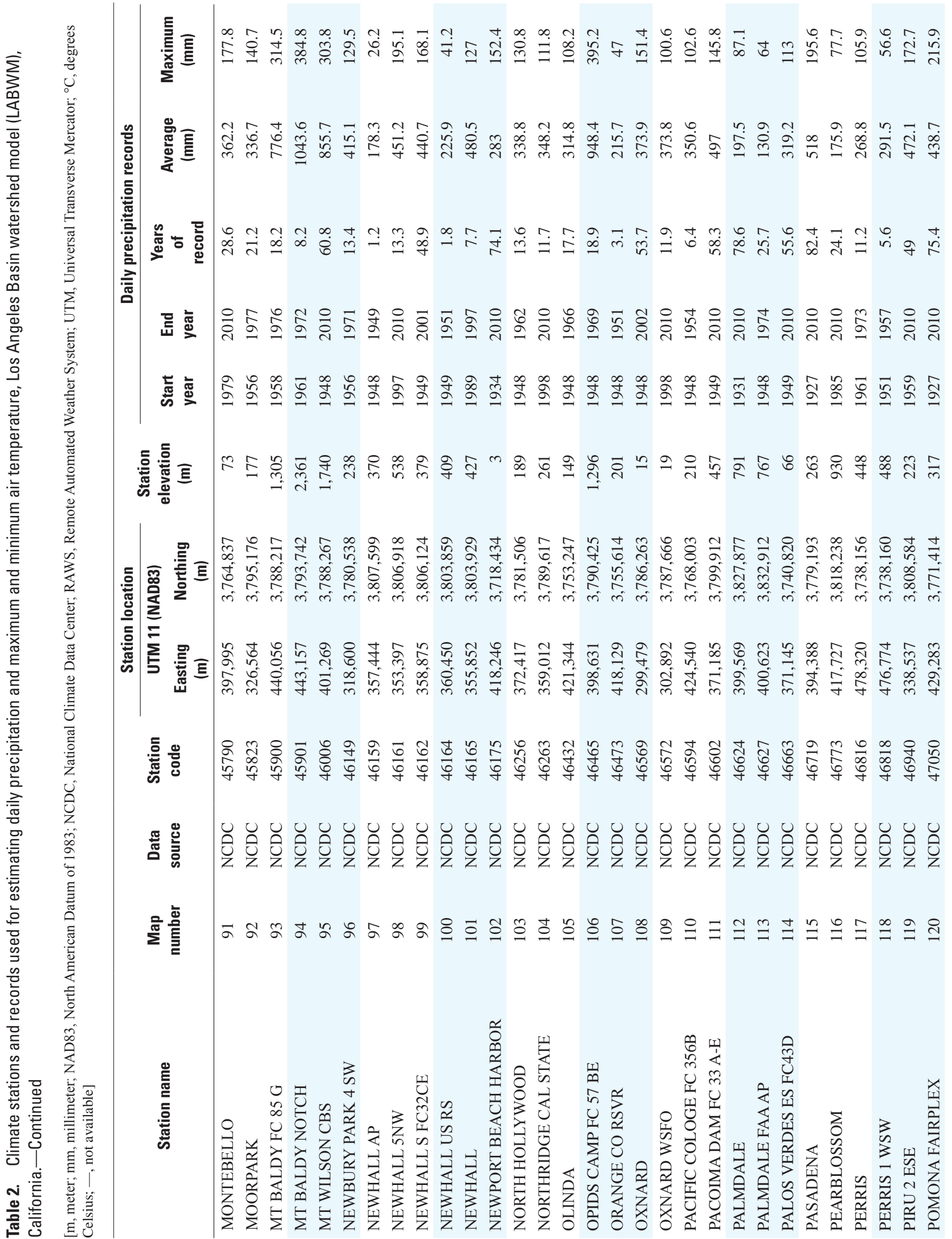




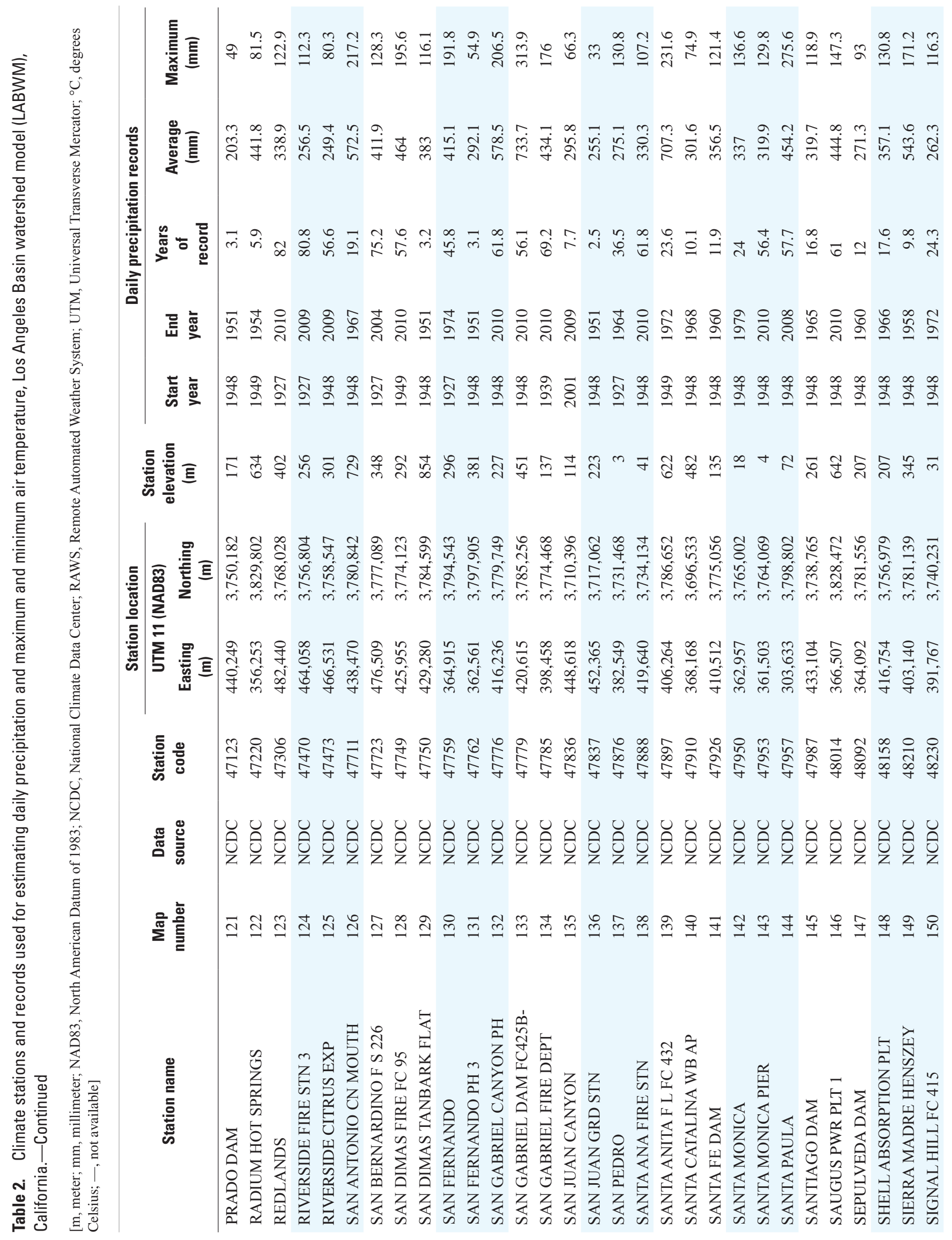




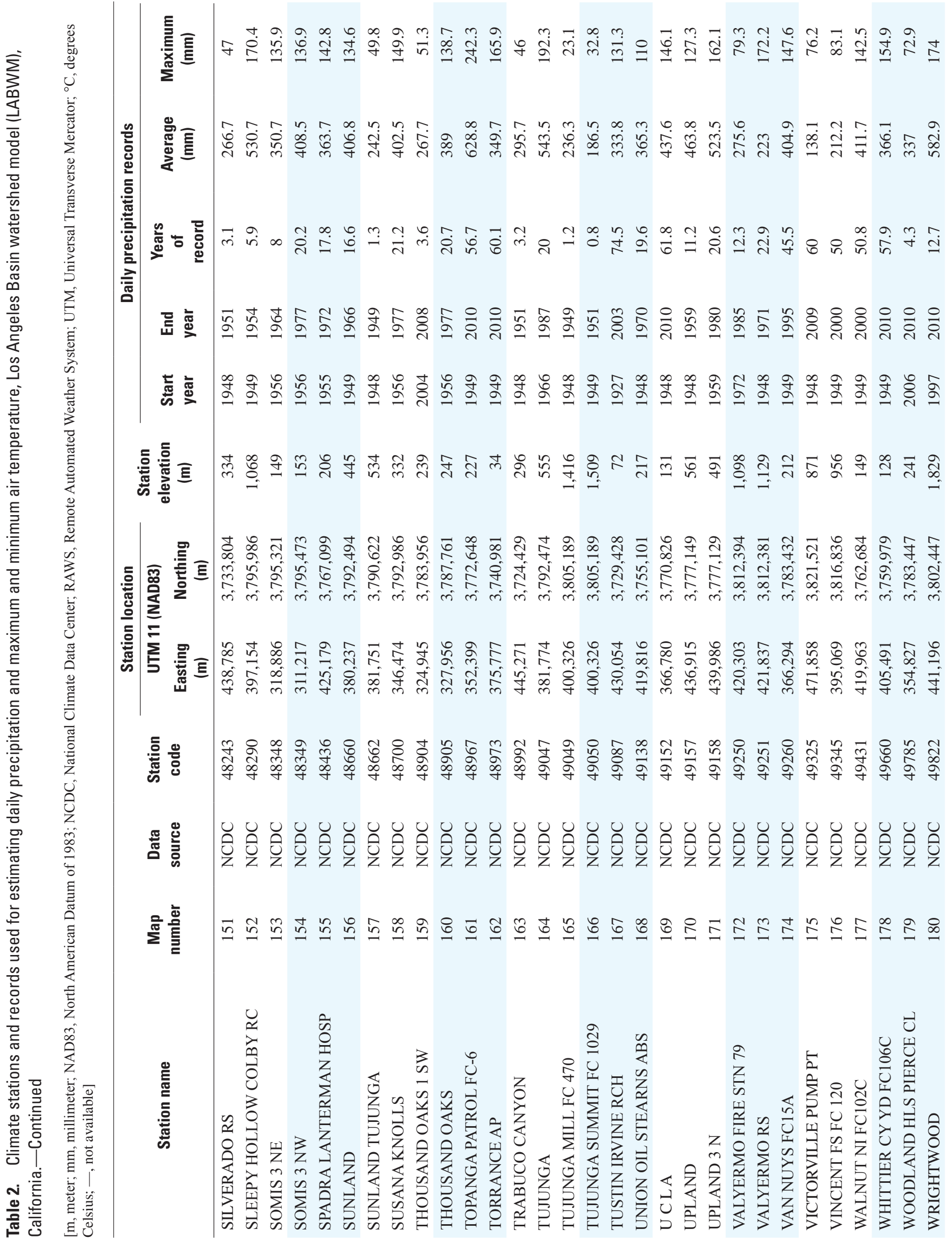




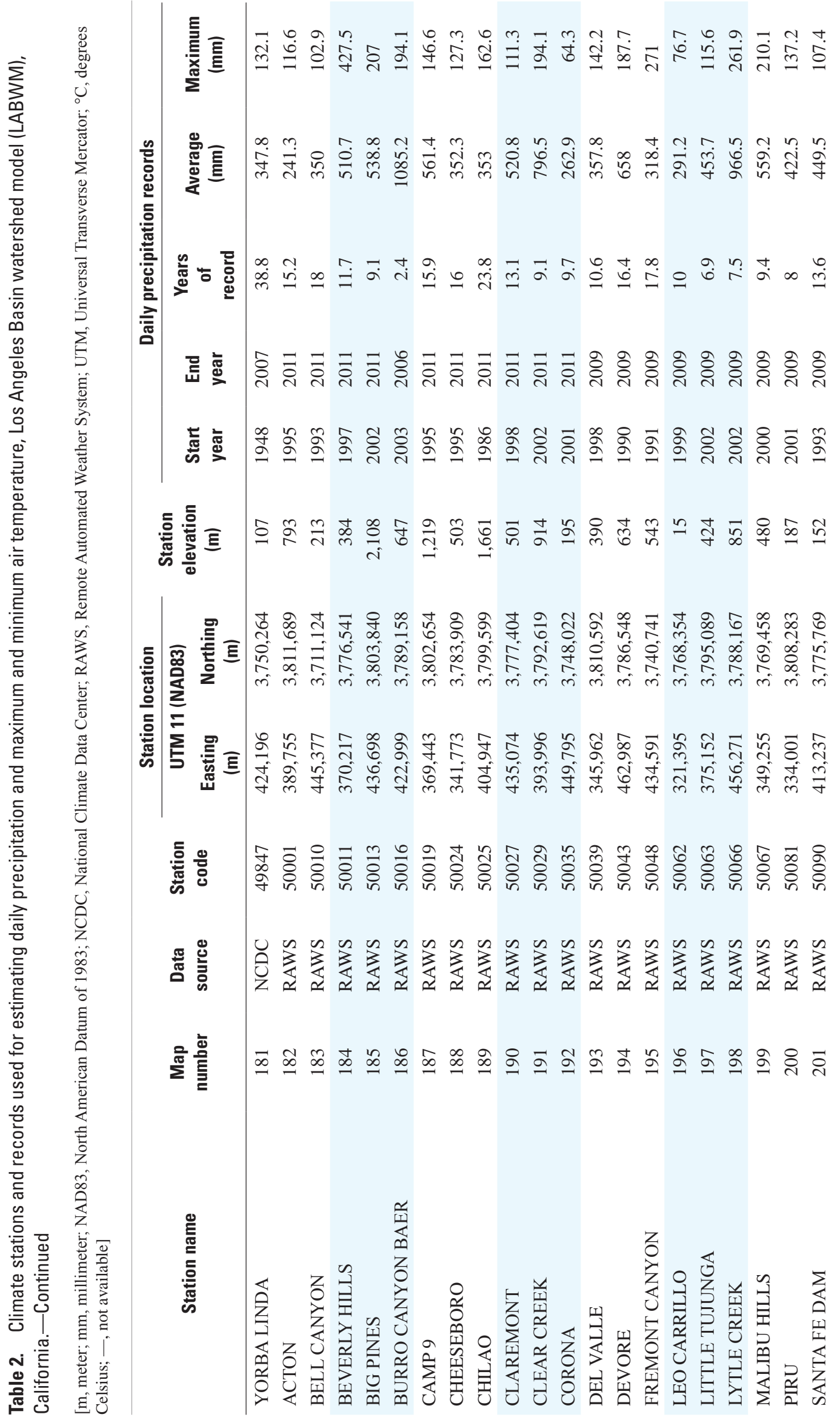




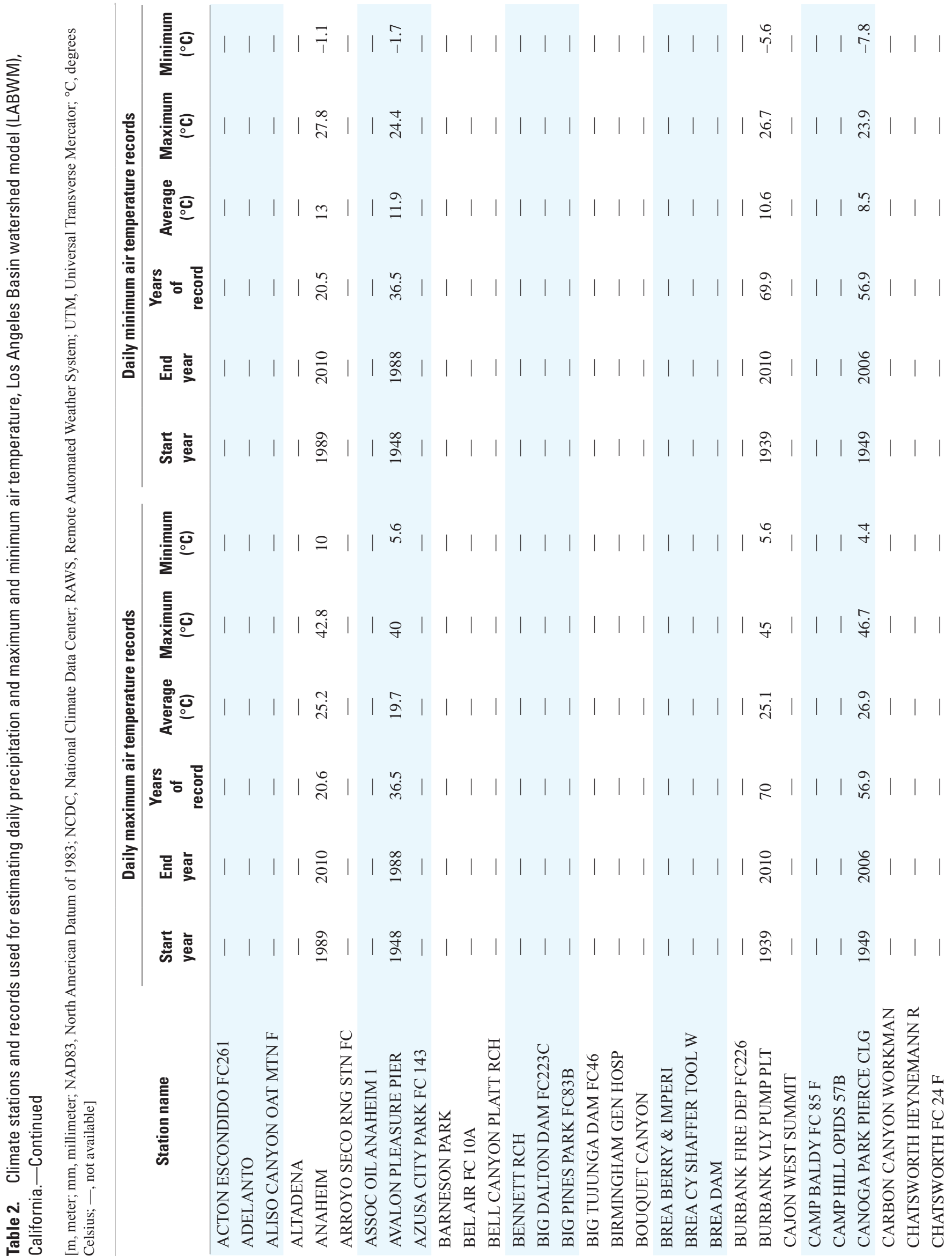




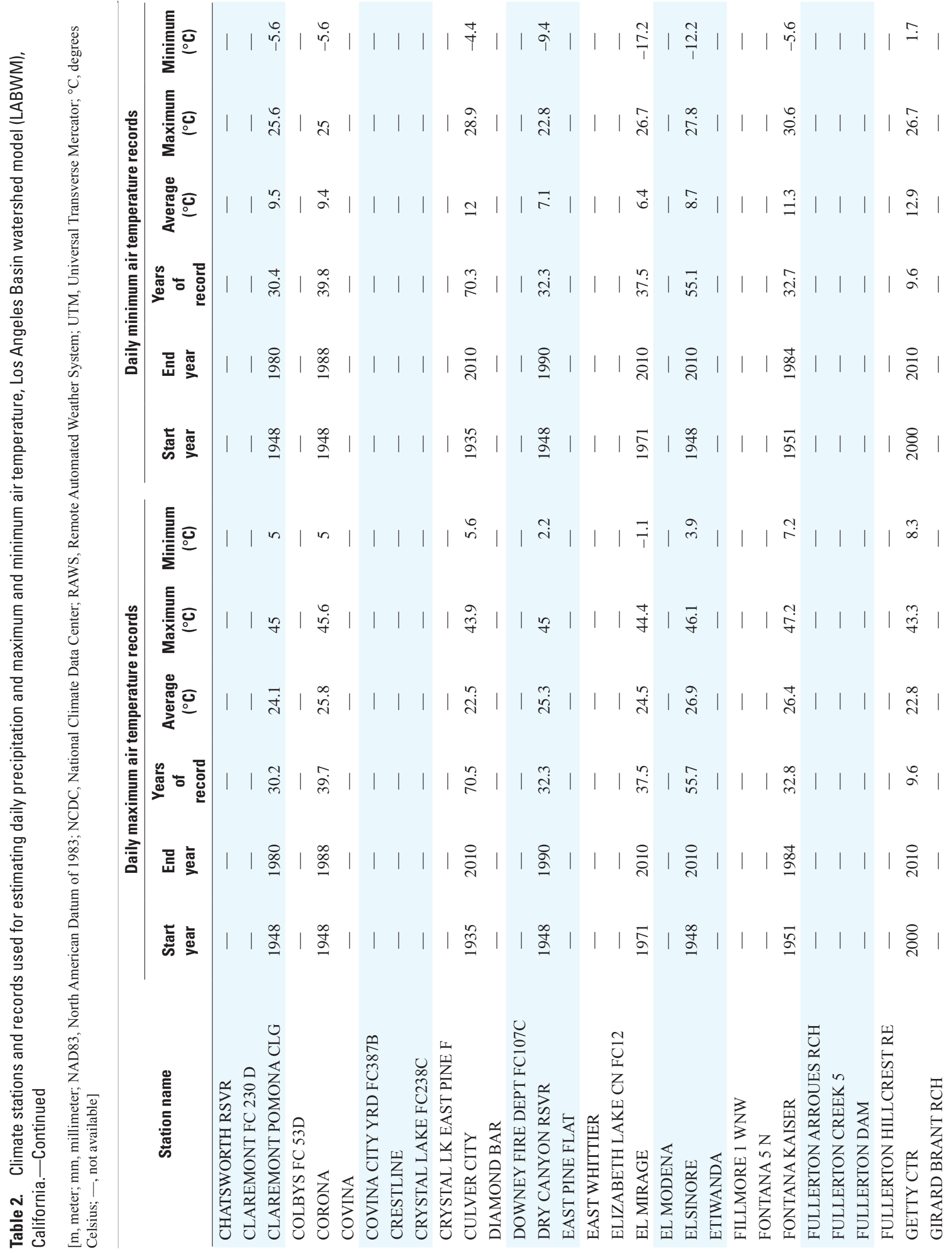




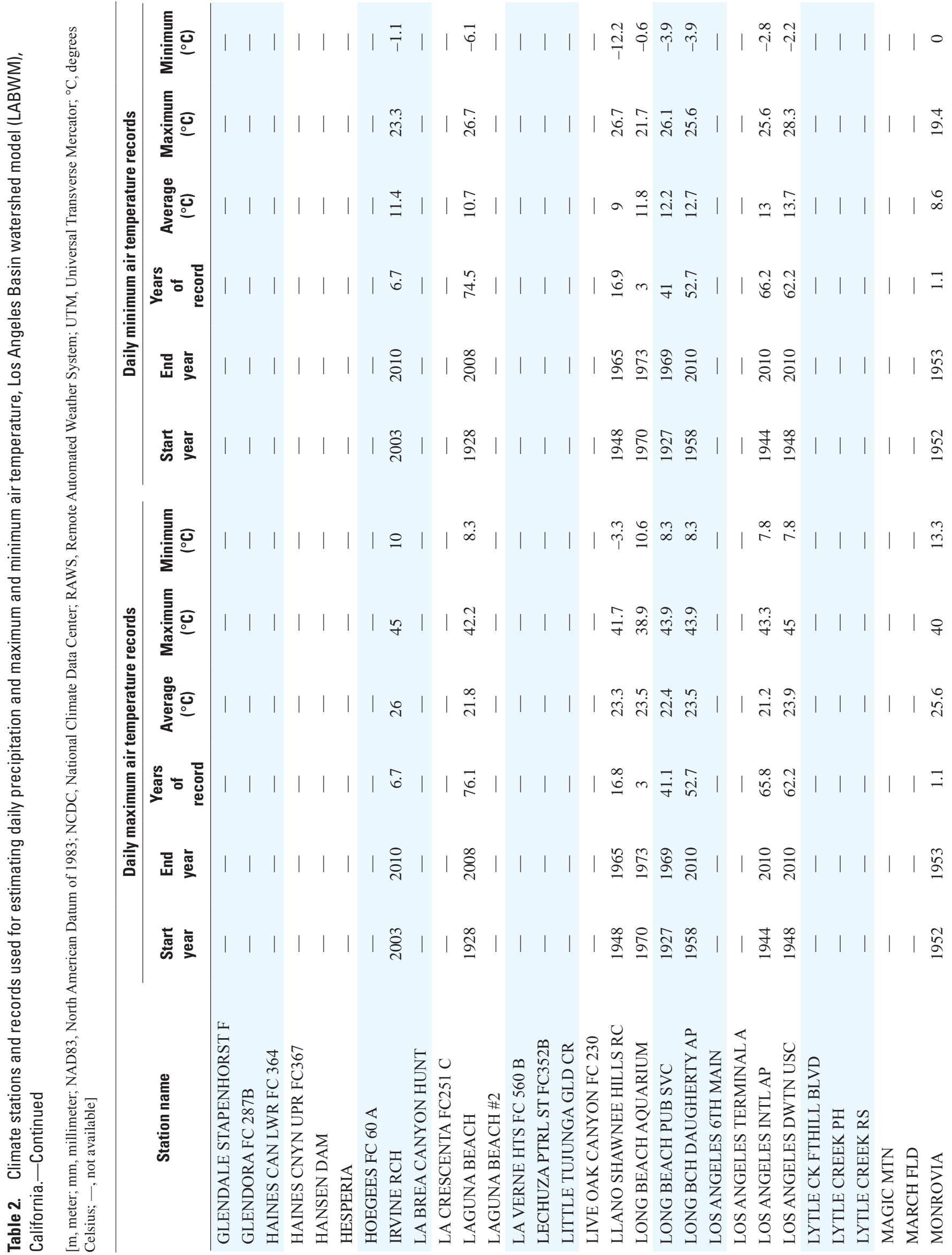




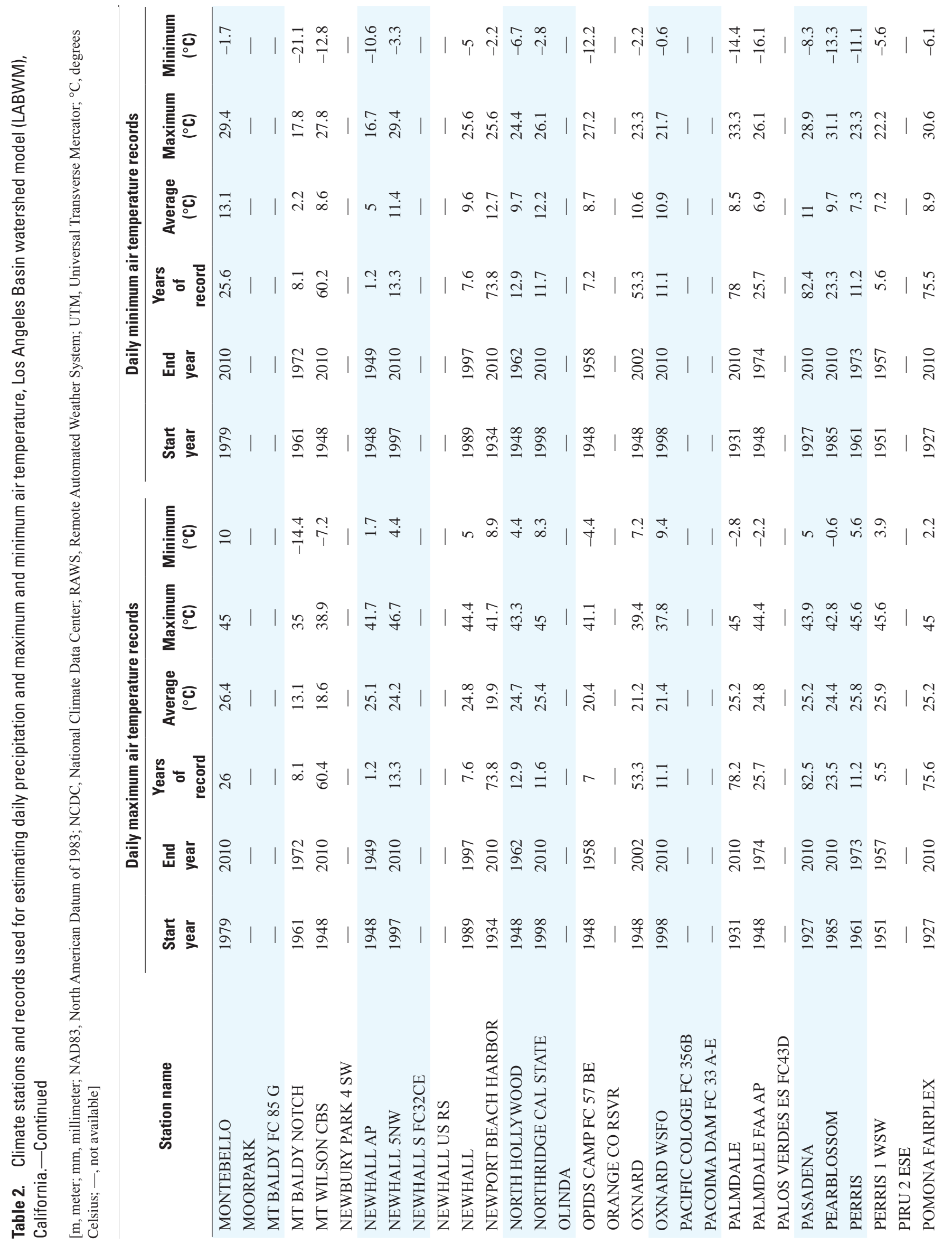


重

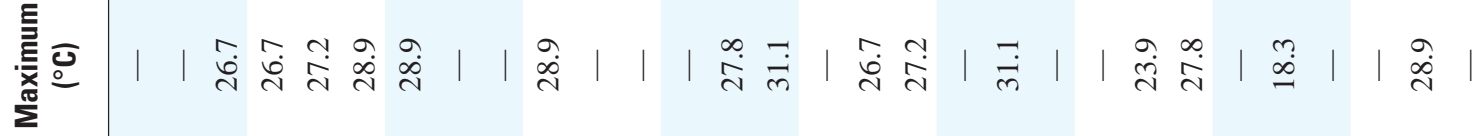

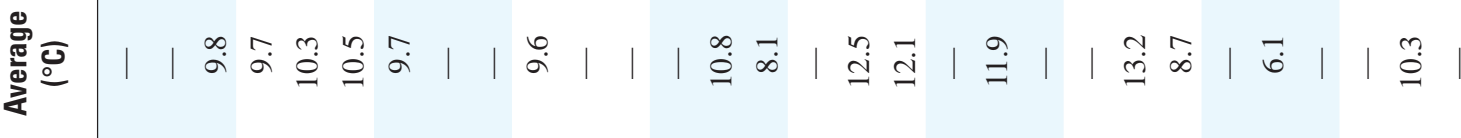
产离

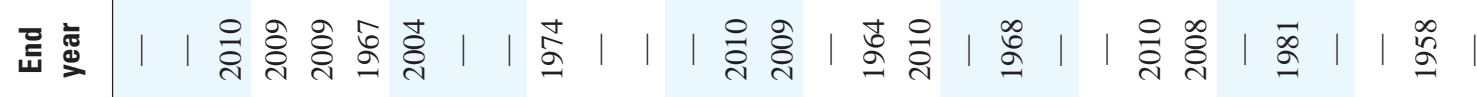

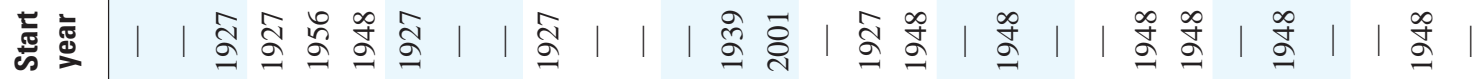

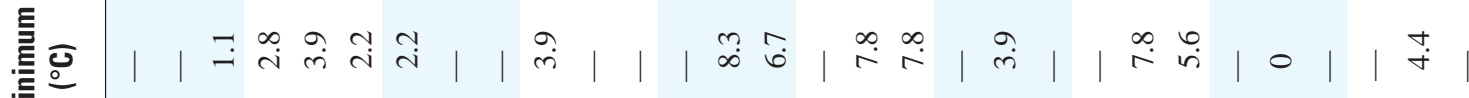

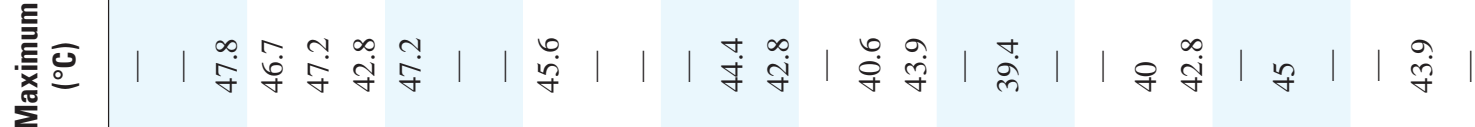

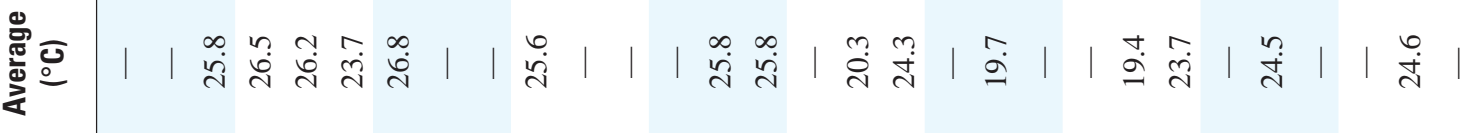

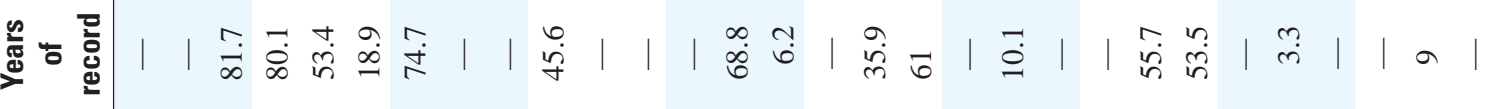

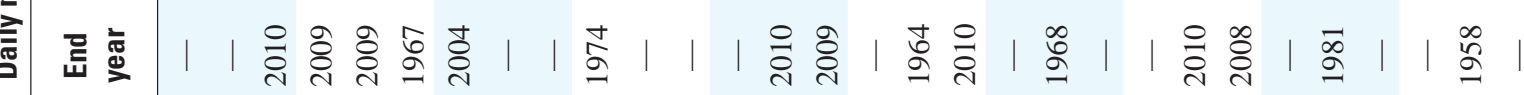

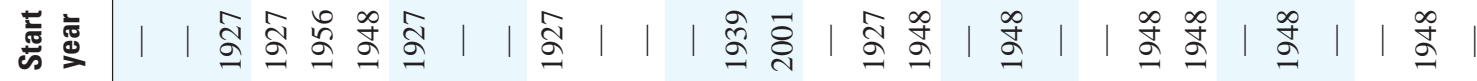

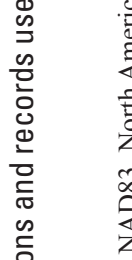




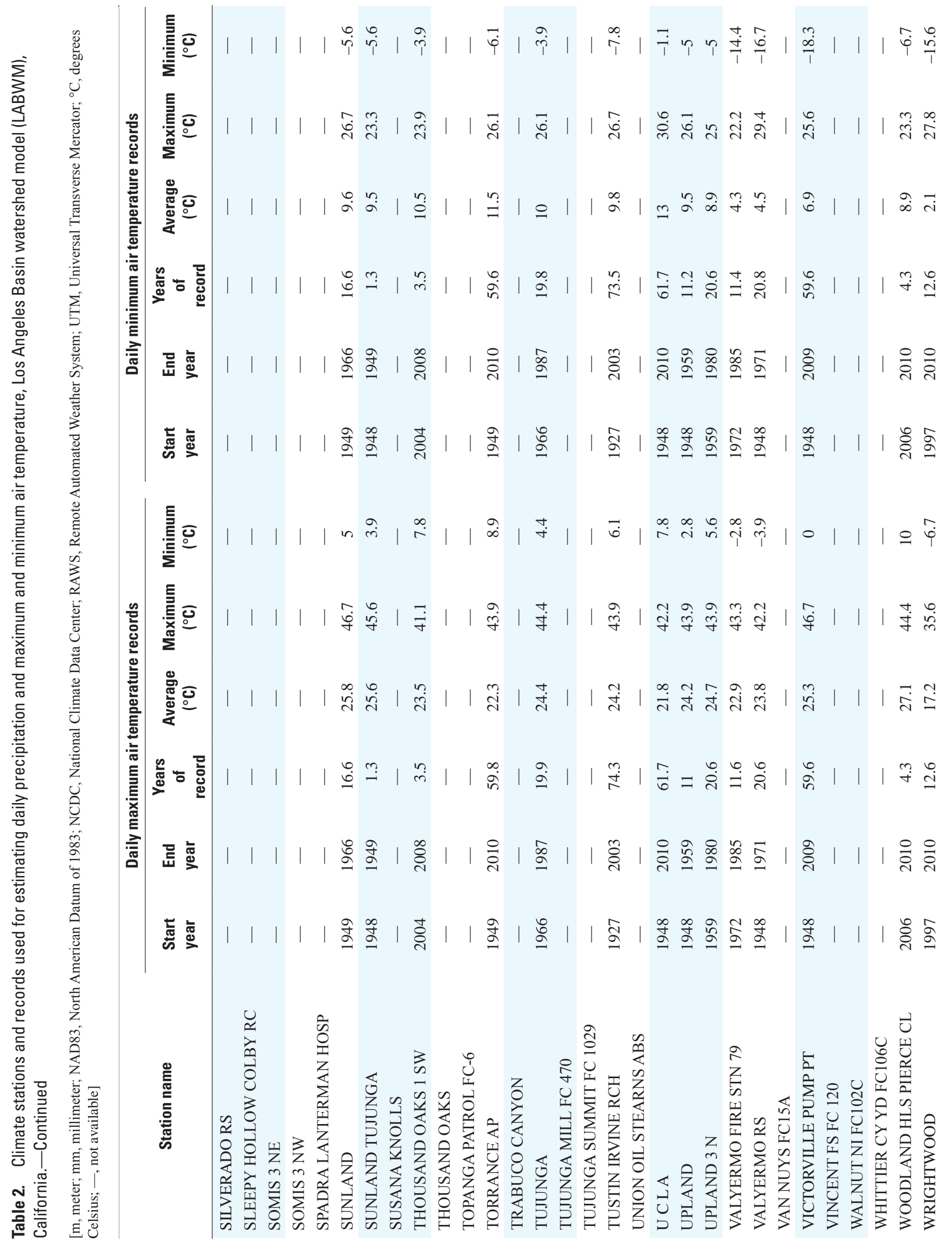




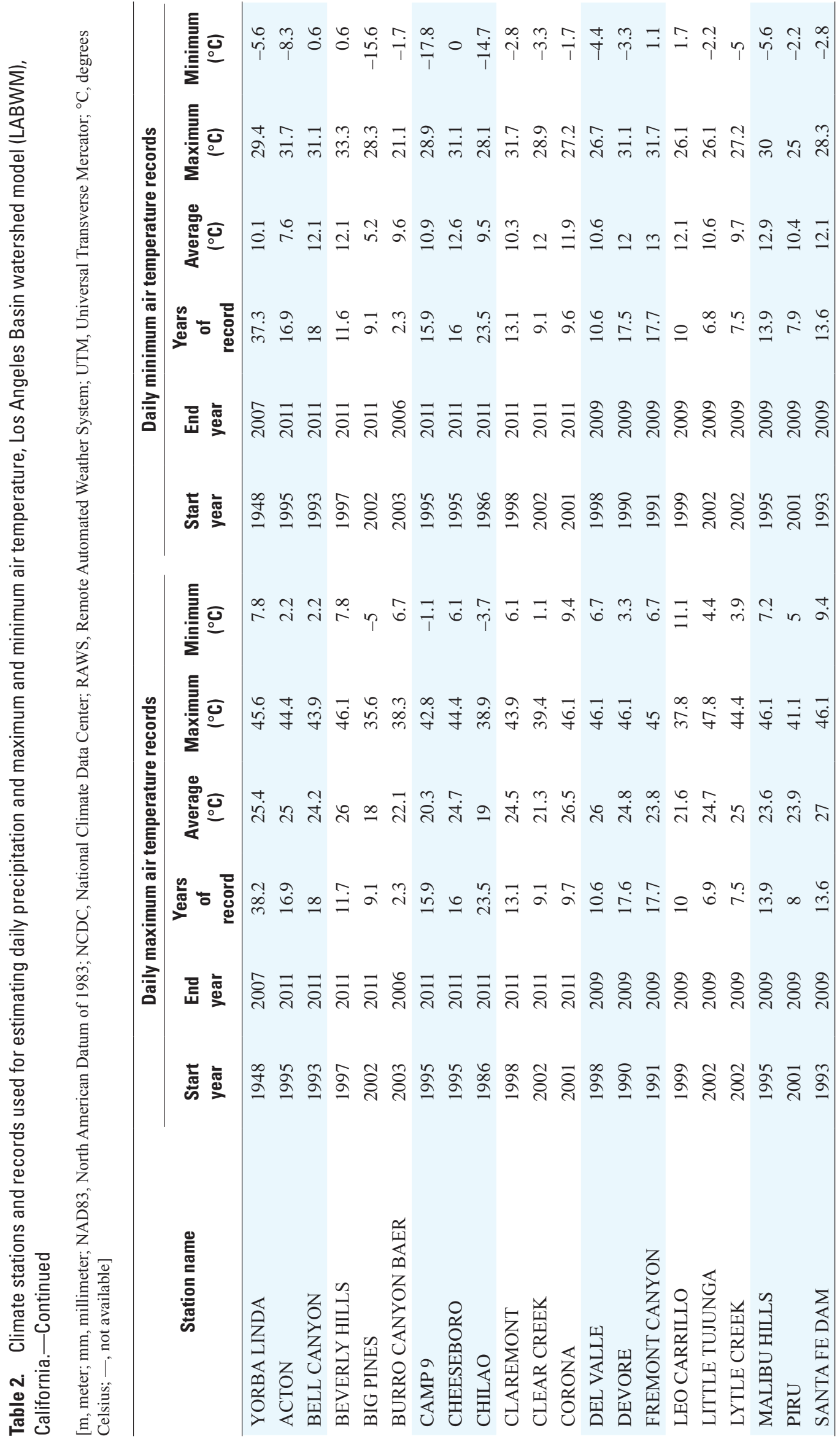


$\boldsymbol{A}$

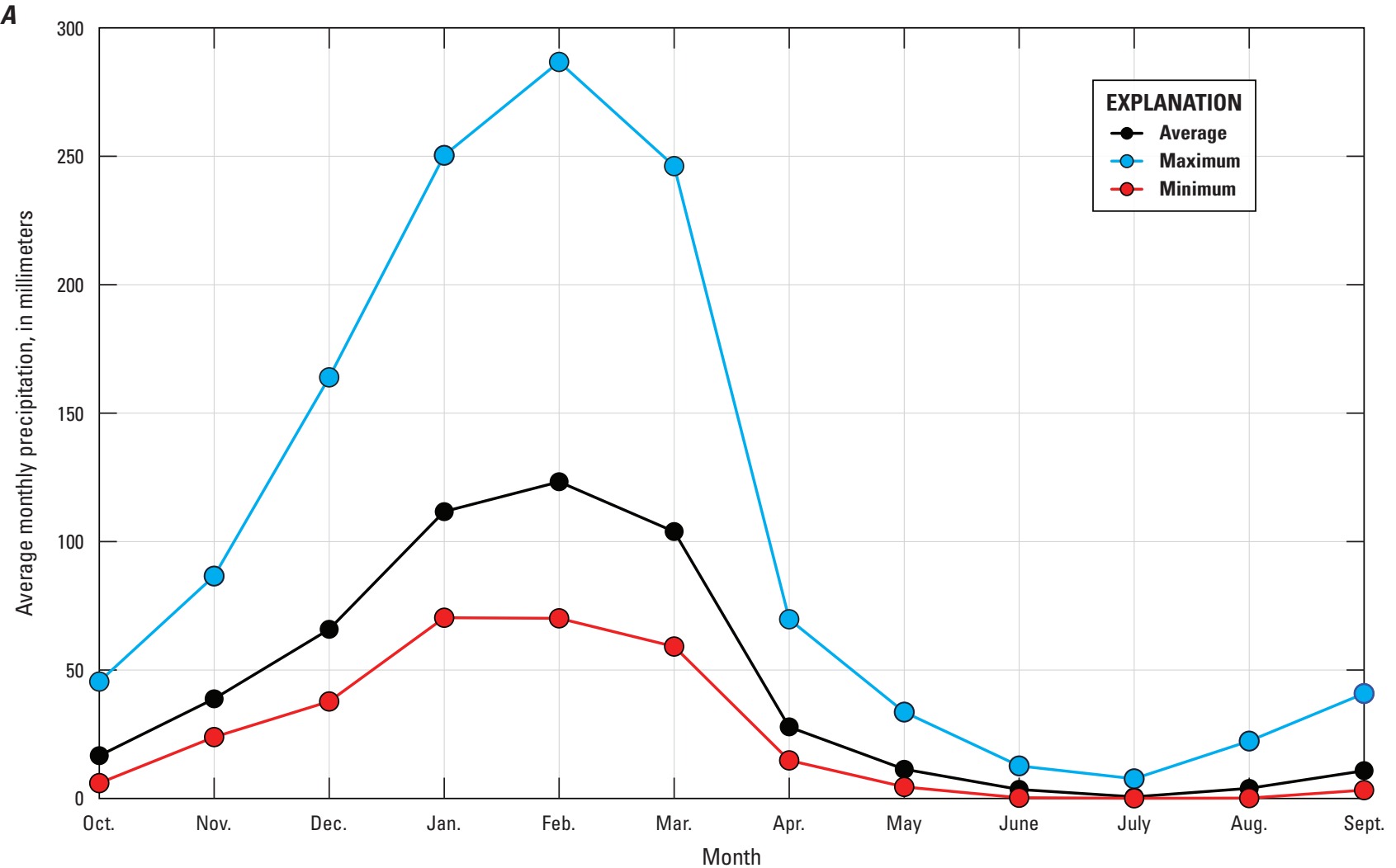

$\boldsymbol{B}$

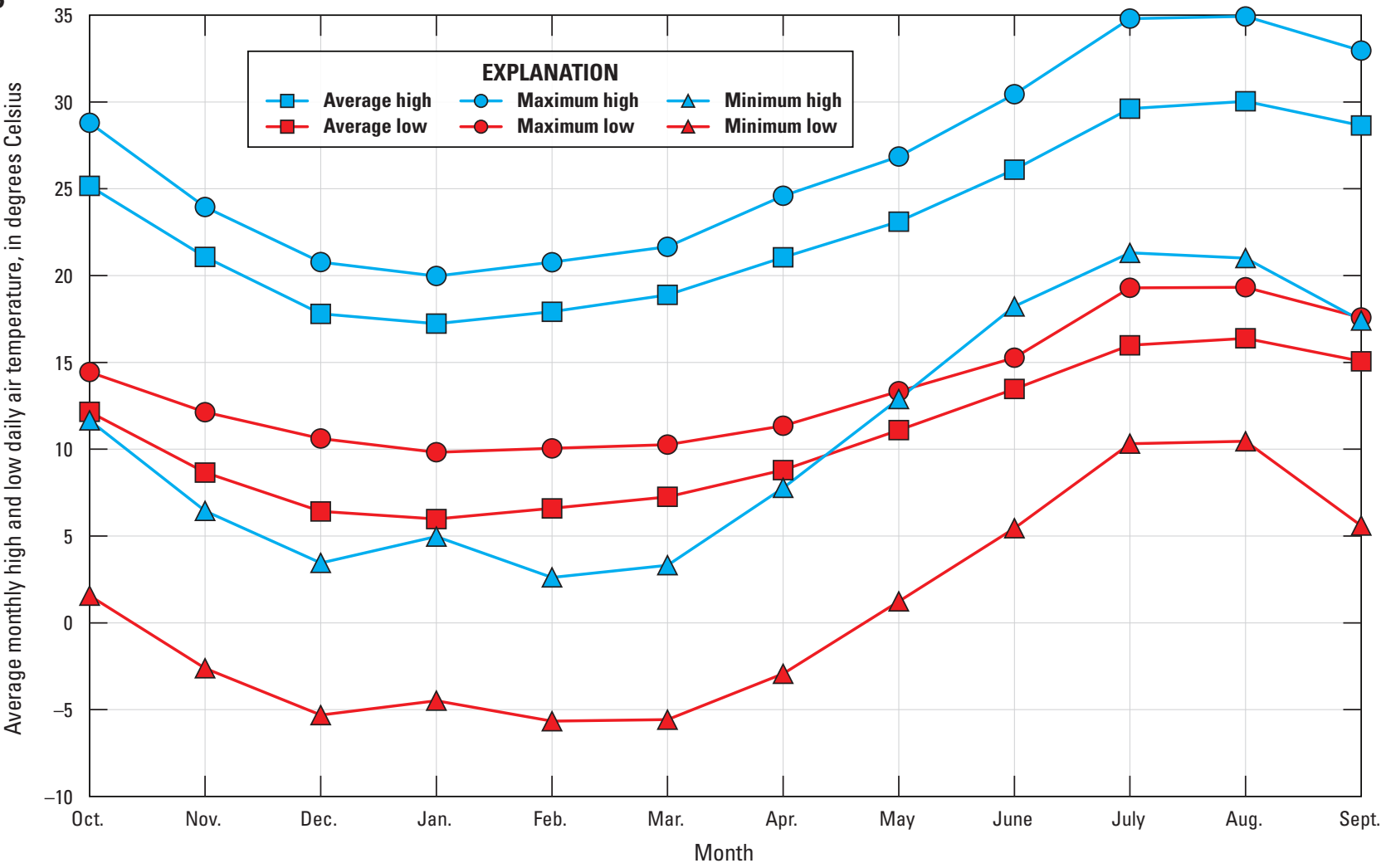

Figure 3. Average monthly values estimated for water years 1915-2014 for the Los Angeles Basin watershed model (LABWM) area, California, for $A$, precipitation; and $B$, maximum and minimum daily air temperature. 
Average monthly maximum and minimum air temperatures in the LABWM area were estimated for water years 1915-2014 by using the modified inverse-distancesquared interpolation, the PRISM 30-year (1971-2000) normal maximum and minimum average daily air temperature (Daly and others, 2004), and daily maximum and minimum air temperature records from a network of 90 climate stations covering the LABWM and having records of daily air temperature (table 2). The results indicate that June through October are generally the hottest months for most locations, with average maximum daily air temperature of more than 25 degrees Celsius for all months, and average minimum daily air temperature of more than 11 degrees Celsius for all months (fig. 3B). Similar to precipitation, average monthly air temperature showed considerable spatial variability in the LABWM area. For example, the average maximum-high temperature for August was 34.9 degrees Celsius, compared to the average minimum high of 20 degrees Celsius.

The notable spatial variability in precipitation and air temperature is based on topography and distance from the coastline. The average annual precipitation for the LABWM, estimated for water years 1915-2014 by using the modified inverse-distance-squared spatial-interpolation method, ranged from 901-1,161 millimeters per year (mm/yr) in the summit areas of the San Gabriel Mountains to 301-400 mm/yr for most of the coast and in the LAGSA (fig. 4). Compared to the interior valley, higher-elevation locations in the foothills bordering San Fernando and San Gabriel Valleys had higher precipitation, including areas with more than $501 \mathrm{~mm} / \mathrm{yr}$ precipitation. In the Los Angeles recharge-study area, relatively high precipitation of 501 to $700 \mathrm{~mm} / \mathrm{yr}$ fell in the Santa Monica Mountains, whereas precipitation was lower, 284 to $400 \mathrm{~mm} / \mathrm{yr}$, in most of the Los Angeles rechargestudy area and the LAGSA. The estimated basin-wide average precipitation rate for water years 1915-2014 for the LABWM area was $488 \mathrm{~mm} / \mathrm{yr}$, compared to a basin-wide average precipitation rate of $336 \mathrm{~mm} / \mathrm{yr}$ for the LAGSA.

Average air temperature in the LABWM area, estimated for water years 1915-2014 by using the modified inversedistance-squared spatial-interpolation method, ranged from high values of about 18-19 degrees Celsius for many areas in the San Gabriel and San Fernando Valleys to low values of about 6-10 degrees Celsius for the highest elevations in the San Gabriel Mountains (fig. 5). In the Los Angeles rechargestudy area, the warmer average daily air temperatures of about 18 to 19 degrees Celsius were measured in the higher elevations of the Santa Monica Mountains and throughout the northeastern part of the model area. Cooler average daily air temperatures of about 17 degrees Celsius were measured along the coast. The mean daily air temperature in the LABWM area was 16.8 degrees Celsius.

\section{Influence of Urban Irrigation}

Urban irrigation can influence the groundwater hydrologic cycle by increasing the amount of water available to infiltration through on-site percolation (Grimmond and others, 1986) and can influence the surface-water hydrologic cycle by affecting runoff rates from rainfall (Sample and Heaney, 2006). The volume of urban irrigation applied to the landscape can be large, exceeding natural rainfall in certain areas such as the Los Angeles Basin (California Department of Water Resources, 1975). Among the urban land uses that irrigate, residential areas typically use the most water in an urban environment compared to commercial, industrial, and agricultural users (Grimmond and Oke, 1986; California Department of Water Resources, 1994; City of Los Angeles Department of Water and Power, 2001; San Diego County Water Authority, 2001). In addition, residential neighborhoods occupy the largest area of all the land-use classes in the Los Angeles Basin (Southern California Area Governments, 2005). Studies have shown that more than 50 percent of the water used in a typical household is used for irrigation (Grimmond and Oke, 1986; Mayer and others, 1999). For the residential areas in the city of Los Angeles, for example, this equates to approximately 225 million cubic meters (22,500 ha-m) of water used for irrigation each year, potentially influencing the urban hydrologic cycle (Johnson and Belitz, 2012). Ideally, most or all of the applied urban irrigation water would be used by plants and, thus, lost to evapotranspiration (ET). Overwatering, because it is difficult to estimate the exact water demand, is not uncommon, and a portion of the applied water can contribute to recharge and runoff in addition to ET. An increase in recharge and runoff can also increase in response to natural precipitation because of the wet antecedent soil conditions caused by urban irrigation.

\section{Model Description}

The FORTRAN code INFILv3 simulates daily precipitation-runoff processes on a watershed scale by using a daily root-zone water balance that accounts for the infiltration of runoff, which can result in areas of locally high net infiltration and recharge where surface-water inflows are concentrated or frequent (U.S. Geological Survey, 2008). Application of INFILv3 allows for the estimation of spatially distributed water-budget components on a daily, monthly, and annual basis. The INFILv3 simulation results are used to gain a better understanding of mechanisms responsible for net infiltration, evapotranspiration, runoff, and recharge. Model results can be mapped and, subsequently, used to evaluate the integrated effect of spatially distributed climate, terrain, and watershed characteristics (for example, vegetation, soils, and geology) on the spatial and temporal distribution of waterbudget components, including runoff and recharge. 


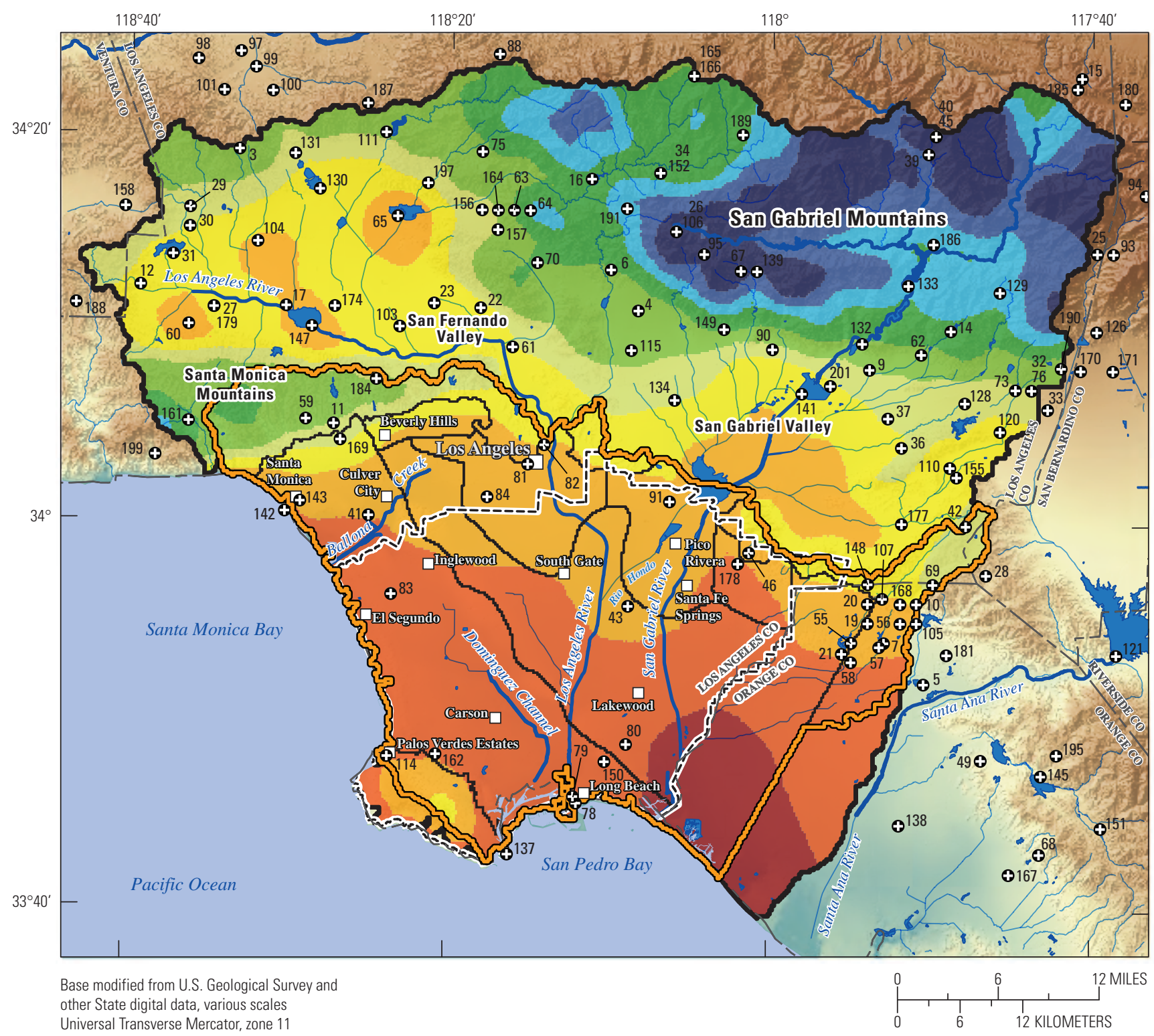

Universal Transverse Mercator, zone 11

North American Datum 1983

\section{EXPLANATION}

Los Angeles Basin watershed model interpolated 1915-2014 precipitation, in millimeters per year

\begin{tabular}{|c|c|}
\hline $284-300$ & $501-600$ \\
\hline $301-350$ & $601-700$ \\
\hline $351-400$ & $701-800$ \\
\hline $401-450$ & $801-900$ \\
\hline $451-500$ & $901-1,161$ \\
\hline
\end{tabular}

Los Angeles Basin watershed model area boundary Water Replenishment District

Los Angeles recharge study area

Water bodies and flood-control areas

Major rivers and streams

_ Minor rivers and streams

- Los Angeles groundwater basins

- County line

$\boldsymbol{\oplus}^{167}$ Climate stations (map number from table 2)

Figure 4. Average annual precipitation estimated for water years 1915-2014 for the Los Angeles Basin watershed model (LABWM), California. 


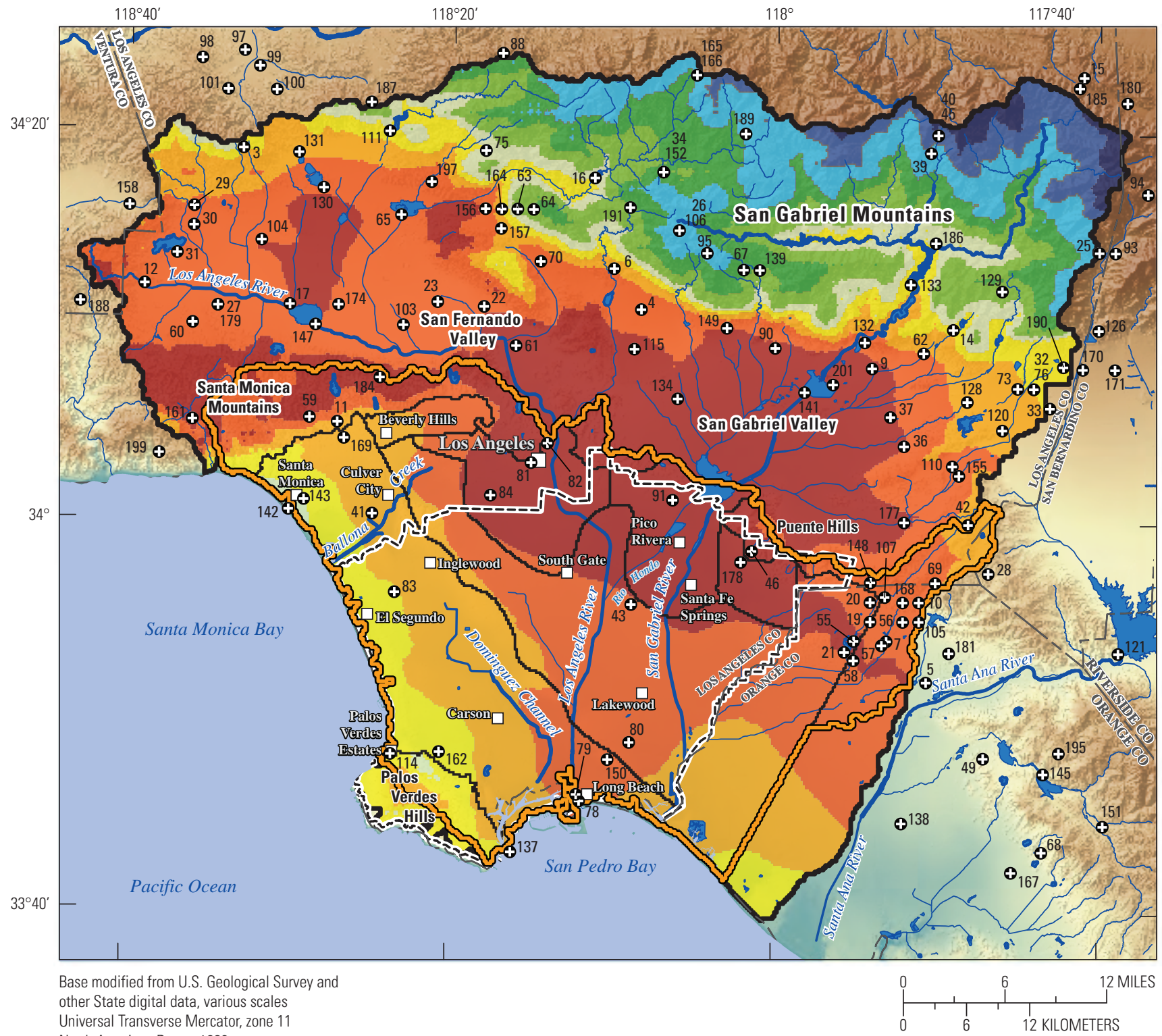

Universal Transverse Mercator, zone 11

North American Datum 1983

\section{EXPLANATION}

\begin{tabular}{|c|c|}
\hline $5.92-10.00$ & $16.10-16.50$ \\
\hline $10.10-12.00$ & $16.60-17.00$ \\
\hline $12.10-14.00$ & $17.10-17.50$ \\
\hline $14.10-15.00$ & $17.60-18.00$ \\
\hline $15.10-16.00$ & $18.10-18.80$ \\
\hline
\end{tabular}

\begin{tabular}{l} 
Los Angeles Basin watershed model area boundary \\
Water Replenishment District \\
\hline Los Angeles recharge study area \\
Water bodies and flood-control areas \\
Major rivers and streams \\
- Minor rivers and streams \\
-- Cos Angeles groundwater basins \\
$\Phi^{167}$ Climate stations (map number from table 2)
\end{tabular}

Figure 5. Average air temperature estimated for water years 1915-2014 for the Los Angeles Basin watershed model (LABWM), California. 
In contrast to empirical precipitation-scaling methods (Maxey and Eakin, 1949; Crippen, 1965; Reichard and others, 2003; Farrar and others, 2006), INFILv3 provides a deterministic, hydrologic process-based method for estimating spatially varying, transient runoff and recharge. Conceptually, the use of a watershed model could provide a better representation, compared to empirical methods, of variations in runoff and recharge caused by the spatially and temporally varying physical and climatic characteristics of the watersheds modeled. The INFILv3 code was intended to provide an estimate of the temporally and spatially varying natural-recharge component (recharge in response to rainfall, snowmelt, and runoff) of the total recharge to the LAGSA. Because of the large amount of urban irrigation in the LAGSA, in this study, the INFILv3 code was modified to include urban irrigation as an addition to the spatially distributed daily precipitation input to enable simulation of the urban return-flow component of anthropogenic recharge. As mentioned previously, this study did not account for induced recharge from retention basins, spreading grounds, and injection wells. These volumes of recharge are quantified by the WRD (Water Replenishment District of Southern California, 2013).

The INFILv3 code is a grid-based, distributed-parameter, deterministic water-balance application for simulating daily precipitation-runoff on the watershed scale. The INFILv3 code is similar to that of other precipitation-runoff models, such as the Basin Characterization Model (BCM; Flint and Flint, 2012), the Soil Water Balance Model (SWB; Westenbroek and others, 2010), and the Precipitation Runoff Modeling System (PRMS; Markstrom and others, 2008). Unlike the BCM, however, the INFILv3 code allows for the daily routing of surface-water and seepage flows from upstream to downstream grid cells, and unlike BCM, SWB, and PRMS, INFILv3 uses a multi-layer discretization to simulate the redistribution of water in the root zone in response to downward percolation and variable transpiration. The INFILv3 code calculates the temporal and spatial distribution of daily net infiltration of water across the lower boundary of the root zone. The bottom of the root zone is the estimated maximum depth below ground surface affected by ET. In many field applications, net infiltration can be assumed to equal recharge to an underlying water-table aquifer and can be used to define the recharge boundary condition for groundwater-flow models (Hevesi and others, 2003; Nishikawa and others, 2005; Rewis and others, 2006). A more detailed description of INFILv3 model is provided in Hevesi and others (2003), and documentation of the model is available at http://water.usgs.gov/nrp/gwsoftware/ Infil/Infil.html (United States Geological Survey, 2008).

The INFILv3 code requires that the watershed being simulated is discretized into a horizontal gridbased network of square, equal-area model cells (fig. 6). The grid-based discretization was used to spatially distribute daily precipitation and daily maximum and minimum air-temperature estimates by using a modified inverse-distance-squared interpolation, daily climate records from a network of climate stations, and estimates of average monthly precipitation and maximum and minimum air temperature (Hevesi and Christensen, 2015; Flint and Martin, 2012). The grid-based discretization is also used to distribute model parameters representing the physical characteristics of the watersheds in the model domain. Each grid cell is uniquely defined in terms of climate inputs and model parameters. The model cells are connected into a drainage network, and runoff generated by a cell is routed across the grid using a convergent-flow, cascade-routing process (Hevesi and others, 2003).

The INFILv3 code provides an estimate of recharge based on simulated daily net infiltration, where net infiltration is defined as the percolation of water from rain, snowmelt, and runoff below the maximum depth of the root zone or the zone of ET (Hevesi and others, 2003). Daily net infiltration and ET are simulated by INFILv3 by using a multi-layered representation of the root-zone, and simulated daily runoff is allowed to infiltrate into the root-zone during the process of surface-water flow routing, thereby accounting for the effects of streamflow on recharge (fig. 6A).

The INFILv3 code has been applied to studies of groundwater recharge in the southern California region, including studies of the Death Valley regional flow system (Hevesi and others, 2003), the Joshua Tree Basin (Nishikawa and others, 2005), and the San Gorgonio Pass area (Rewis and others, 2006). In these studies, simulated net infiltration was used as an estimate of recharge. The more recent applications of INFILv3 for the Big Bear Valley and San Gorgonio Pass study areas in southern California used a modified version of the code that incorporated an additional layer underneath the root zone, referred to as a shallow perched zone, to improve estimation of recharge by accounting for the effects of lateral groundwater flow and seepage (Flint and Martin, 2012; Hevesi and Christensen, 2015). The modified INFILv3 code version that includes a shallow perched zone was used in the LABWM.

\section{Root-Zone Water Balance}

The INFILv3 code uses up to six layers to simulate the root-zone water balance, including net infiltration through the root zone. The modified INFILv3 code includes a seventh layer underlying the root zone, referred to as the shallow perched zone, to simulate lateral groundwater flow in the upper unsaturated zone (fig. 6B). The root zone is modeled by using a maximum of five upper layers to represent the soil component of the root zone and a lower sixth layer to represent the geologic unit (either bedrock or unconsolidated deposits) underlying the soil zone (fig. 6A). All root-zone layers can have uniform or variable thicknesses and are parameterized by using maps of geology (Jennings, 1997), soils (U.S. Department of Agriculture, 1994), and vegetation (California Department of Forestry and Fire Protection, 2002). 
$\boldsymbol{A}$

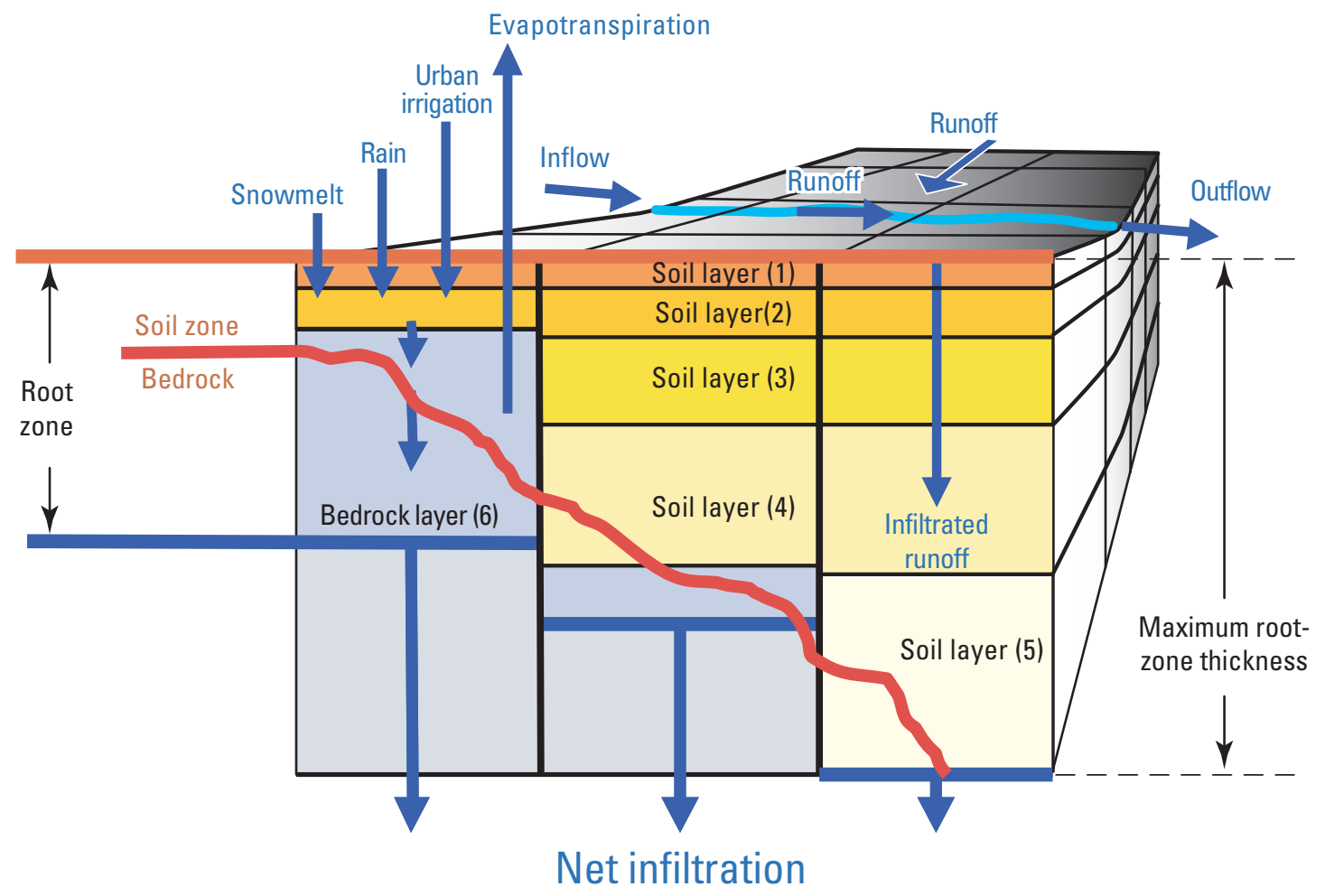

$B$

Evapotranspiration

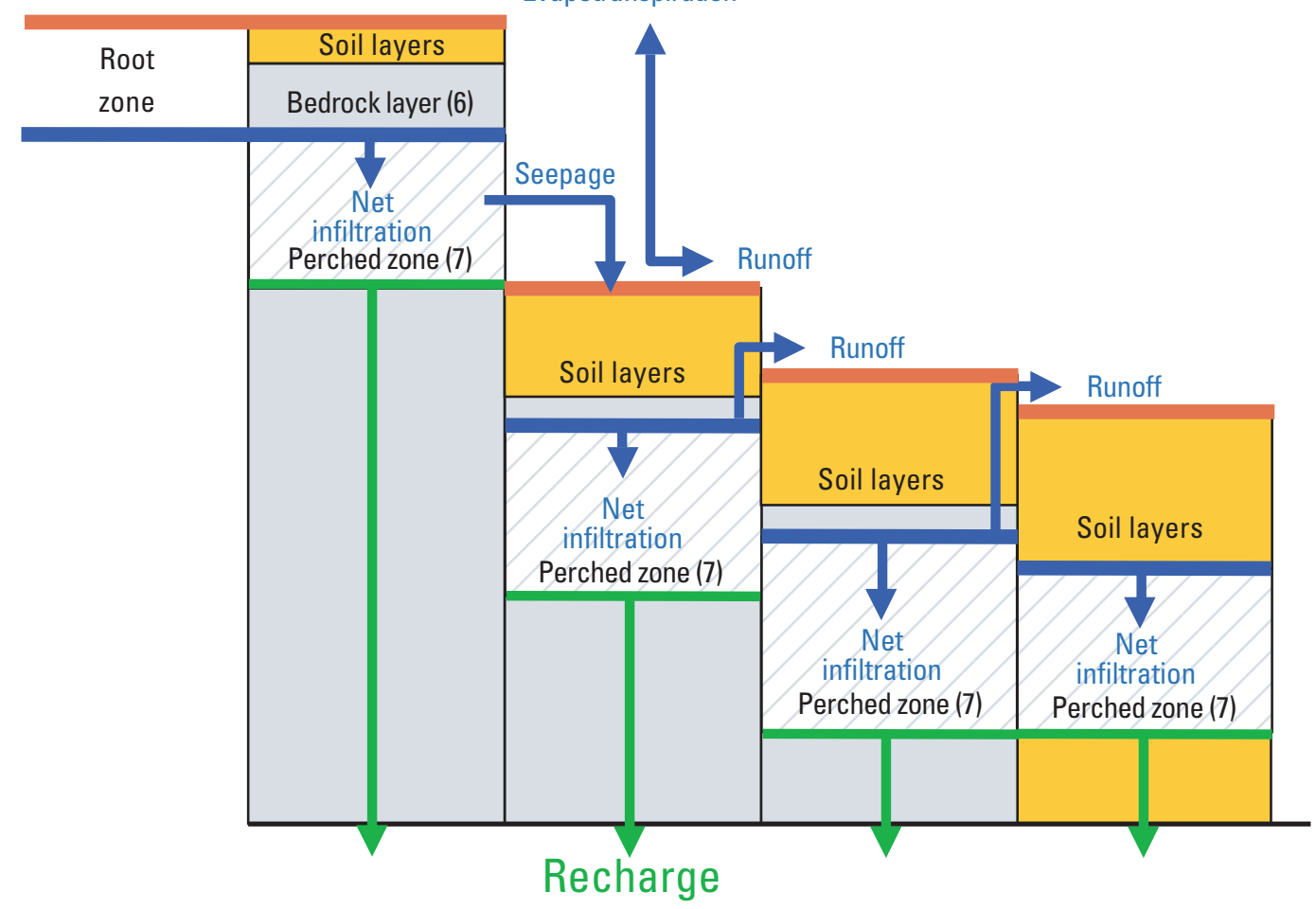

Figure 6. Grid, water storage components, and flow processes used by the INFILv3 code to simulate the spatial distribution of flows by the Los Angeles Basin watershed model (LABWM), California: $A$, the multi-layered root zone; $B$, the perched zone. 
The bottom of the root zone is the estimated maximum depth below ground surface affected by ET.

The INFILv3 code does not directly account for interception storage and surface-retention storage; however, the model can indirectly account for these components by increasing the estimated soil thickness, which has the effect of increasing ET by increasing the storage capacity of the root zone. The water-balance calculations are based on water volumes, rather than water mass, because it is assumed that temperature effects on water density are negligible. The calculations use water-equivalent depths to represent volumes because all grid cells have equivalent areas.

The INFILv3 code uses a daily time step for simulating the water balance of the root zone and an hourly time step for simulating solar radiation and potential evapotranspiration (PET). The simulated daily water balance of the root zone includes precipitation (as either rain or snow), snow accumulation, sublimation, snowmelt, infiltration to the root zone, ET, percolation through the root zone, water-content changes for each root-zone layer, surface-water runoff, and net infiltration from the root zone (defined as drainage from the bottom root-zone layer; fig. 6A). Daily PET is simulated by using an hourly time step and an energy-balance model to improve representation of the shading effects of rugged terrain relative to changes in solar position during the year (Flint and Childs, 1987). Daily ET is simulated as a combined function of daily PET; the vertical distribution of available water in the root-zone layers; and the root-zone density, where the rootzone density represents the characteristics of vegetation.

\section{Shallow Perched-Zone Fluxes}

The modified INFILv3 code includes a perchedgroundwater zone (layer 7) beneath the bedrock layer (layer 6) to simulate lateral groundwater flow back to the root zone (seepage) and downward flux (recharge) beneath the root zone (Flint and Martin, 2012; fig. 6B). The perched-groundwater zone is used to simulate the seepage of shallow groundwater back into the active root zone, a process that was considered potentially significant in rugged mountainous areas with steep slopes (Rewis and others, 2006; Flint and Martin, 2012; Hevesi and Christensen, 2015). Seepage flow allows for a portion of simulated net infiltration to flow laterally to the active root zone of the downstream cell. In general, the net effect of seepage flow is to reduce recharge for the upstream model cell, while increasing ET and runoff for downstream cells. The additional inflow from seepage can also potentially increase recharge for downstream cells. Basin-wide effect of seepage flow, however, tends to be a reduction in recharge and a corresponding increase in ET.
The shallow perched zone (layer 7) is assigned an upper hydraulic conductivity that defines the rate at which water infiltrates the top of the perched zone and a lower hydraulic conductivity that defines the maximum rate at which water percolates vertically down through the perched zone to become recharge. The upper hydraulic conductivity also is used to define the maximum lateral-seepage rate from upstream cells to downstream cells. The lateral-seepage rate is a function of a calculated hydraulic gradient between the upstream and downstream cells, the relative water content of the upstream cell, and the upper hydraulic conductivity of the upstream cell. A multiplier is included to allow scaling of the upper hydraulic conductivity as a means of representing anisotropy or preferential lateral flow in the perched aquifer (this commonly is done to model preferential flow in watershed models). The hydraulic gradient is calculated by using the elevation difference and horizontal distance between adjacent upstream and downstream cell centroids. The relative water content is calculated as the ratio of water stored in a grid cell at each time step to an assumed perched-zone storage capacity. If the perched-zone storage capacity is exceeded for a given daily time step, the excess water is added back to the root zone; if the root zone is fully saturated, the excess water is added to the surface-water runoff.

\section{Urban Irrigation}

In this study, the INFILv3 code was modified to include estimated urban irrigation as an inflow to the hydrologic system (fig. 6A). As stated previously, urban irrigation is a significant component of the LABWM water balance, potentially resulting in increased recharge and runoff in addition to increased ET. Average daily irrigation rates were estimated on a quarterly basis (January-March, April-June, July-September, and October-December) and incorporated in the model as a boundary condition consisting of a specified daily irrigation rate for each irrigated cell (uniform for each quarter, but varying from quarter to quarter). The location of irrigated cells was defined by using land-use maps. The daily irrigation rates were scaled for each cell by using the percentage of pervious area defined for each cell, as described in greater detail in this section.

Actual water-delivery records that could be used for estimating landscape irrigation in urban and suburban areas were difficult to obtain for most of the LABWM area; however, as part of previous research (Johnson, 2005; Johnson and Belitz, 2012), water records from 1996 to 1999 were acquired from nearly 1,795 single-family residential homes and townhomes in 65 randomized and spatially distributed neighborhoods in the San Fernando Valley. The neighborhoods 
analyzed in the study consisted of 8 to 55 homes, with an average home count of 28. The average neighborhood size was $2.48 \mathrm{ha}$. These water-delivery records were used to estimate the amount of irrigation applied to single-family residential areas and, subsequently, to other land use classes.

The San Fernando Valley study area was initially chosen for a number of reasons: (1) the valley is administered by one city, which allows for consistency of water-delivery records; (2) land use in the valley is representative of other areas of the Southwestern U.S., offering a mixture of residential, commercial, and industrial land uses for constructing and calibrating methodologies; (3) the valley has a wide range of social-economic variables, including income, household size, lot size and water use, allowing a diversity of wateruse patterns; and (4) the valley is surrounded by mountains, isolated from oceanic influences, and relatively flat, which help to minimize the climatic variability across the valley.

Water-delivery data were obtained from the Los Angeles County Department of Power and Water (LACDPW) for October 1996 through April 1999. The data were provided in 2-month billing cycles and were subsequently aggregated and normalized into a monthly water-delivery value for each neighborhood. Neighborhood water-meter readings that contained less than three homes were considered partial readings and not included in the averaging. The water-delivery data were normalized by dividing by the total area of each neighborhood. Figure 7 shows the aggregate water usage for the period sampled.

The minimum-month method was used to estimate irrigation by subtracting the minimum month of water use from all other months (Johnson, 2005). The minimum month is assumed to be composed mostly of indoor water use and represents the baseline water usage; therefore, subtracting the minimum month results in an estimation of irrigation. For the sampling period, the minimum month was March 1998, one of the wettest months during the study period, with a rate of $28.8544 \mathrm{~mm}$ (fig. 7). Irrigation, therefore, was computed as follows:

$$
I_{\text {nhood }}(t)=W D_{\text {nhood }}(t)-28.8544
$$

where

$$
\begin{aligned}
I_{\text {nhood }}(t) & \begin{array}{c}
\text { is the irrigation rate }(\mathrm{mm}) \text { for the average } \\
\text { neighborhood per month, and }
\end{array} \\
W D_{\text {nhood }}(t) & \begin{array}{l}
\text { is the water-delivery rate (mm) for the } \\
\text { average neighborhood per month. }
\end{array}
\end{aligned}
$$

By using equation 1, table 3 was constructed to aggregate irrigation on a quarterly basis. A warmer month with a higher ET rate requires greater amounts of irrigation to keep plants healthy. Averaging the 2 years can produce a general estimate of irrigation applied in the entire neighborhood (table 3).
The estimated irrigation was applied as an average quarterly rate for the entire 110-year simulation period. The average precipitation for the period analyzed (December 1996February 1999) was representative of the long-term average precipitation.

In order to apply an irrigation rate to other landuse classes, the irrigation computed for the residential neighborhoods must be scaled up to a fully landscaped and irrigated parcel by multiplying it by the amount of irrigated landscaping in the neighborhood. This was necessary because the average neighborhood both consisted of an impervious portion (house, driveway, and so on) and a pervious portion (grass, landscaping, and so on). It was assumed that irrigation was applied only to the pervious areas.

$$
I(t)=\left(I_{\text {nhood }}(t)\right) /\left(\text { Firr }_{\text {nhhod }}\right)
$$

where

$$
\begin{array}{cl}
I(t) \quad \begin{array}{c}
\text { is the irrigation rate for a fully irrigated and } \\
\text { landscaped parcel, computed quarterly; } \\
\text { is the irrigation rate (mm) for the average } \\
\text { neighborhood per month; and }
\end{array} \\
I_{\text {nhood }}(t) \quad \begin{array}{c}
\text { is the fraction of irrigated landscaping in the } \\
\text { average neighborhood. }
\end{array}
\end{array}
$$

An estimate of perviousness was based on a land-use map acquired from the Los Angeles County Department of Power and Water (2006). This map consisted of digitized polygons that grouped land-use classes together and identified the amount of imperviousness in each class. Milesi and others (2005) have shown that impervious surface area is inversely correlated to turfgrass in urban areas. The percentage of pervious area for each land-use class, therefore, was calculated by subtracting the reported imperviousness value from 100 percent. All 65 neighborhoods were in the "high-density single-family residential” class, which has a perviousness value of 58 percent (table 4). This value of Firr ${ }_{\text {nhhod }}$ was used in equation 2 to calculate the quarterly irrigation rate for a parcel.

The distribution of urban irrigation was estimated by applying the irrigation rate to selected urban land-use classes and their reported percentage perviousness areas (table 4).

$$
I_{l u}(t)=I(t) \times F_{i r r}
$$

where

$I_{l u}(t) \quad$ is the irrigation rate $(\mathrm{mm})$ for a particular land-use class, computed quarterly;

$I(t) \quad$ is the irrigation rate for a fully irrigated and landscaped parcel, computed quarterly; and

Firr $_{l u} \quad$ is the fraction of irrigated landscaping (perviousness) for a particular land-use class. 


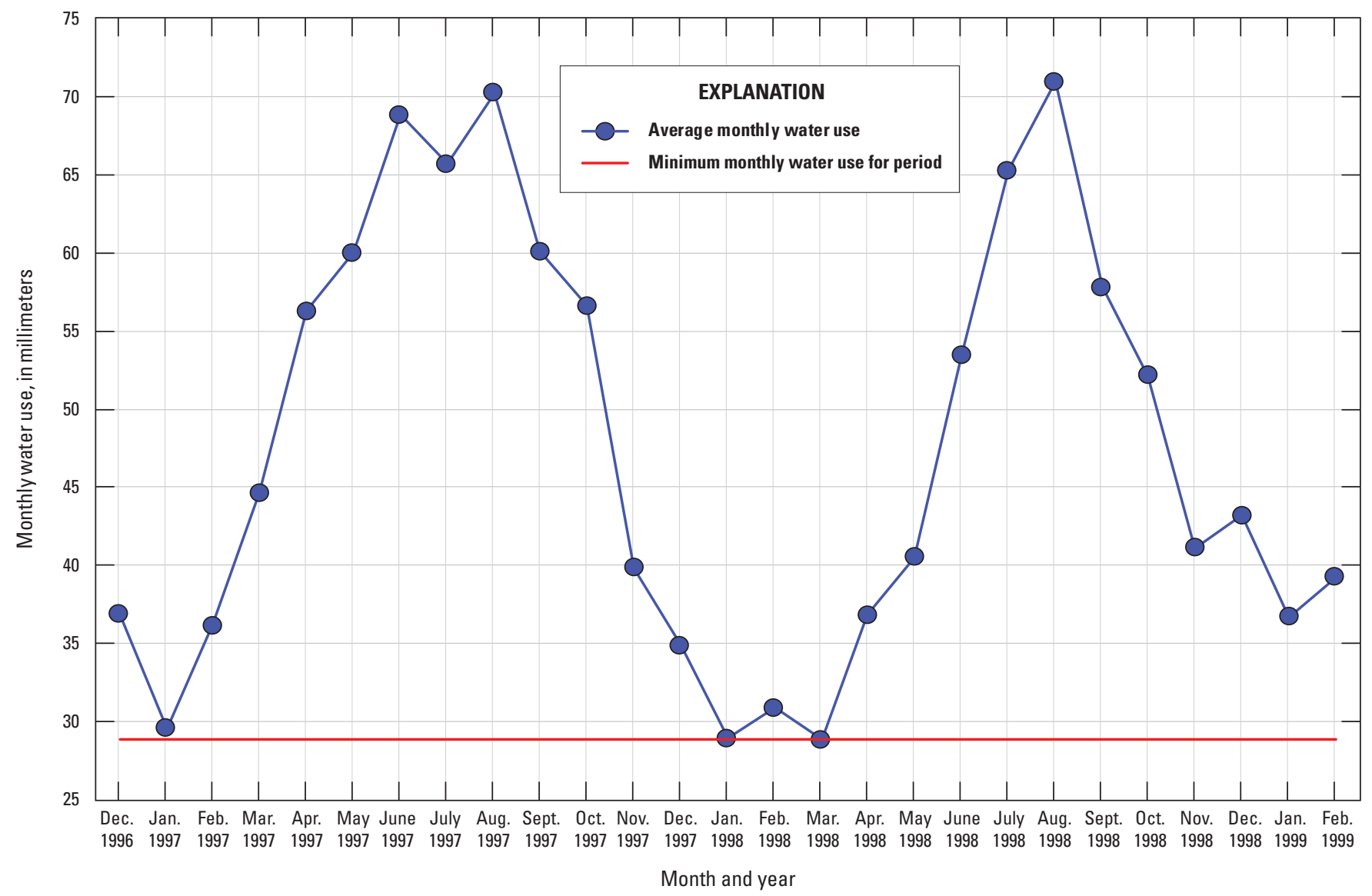

Figure 7. Average water delivery to 1,795 single-family residential homes in the San Fernando Valley, Los Angeles Basin watershed model (LABWM), California (1 millimeter is equal to 1 liter per square meter).

Table 3. Average irrigation rates, in millimeters, estimated for 1,795 high-density single-family residential homes by using the minimum-month method, Los Angeles Basin watershed model (LABWM), California.

[The last column shows the scaled-irrigation rate for a parcel that is fully landscaped and irrigated. The average neighborhood was 58 percent landscaped, based on Los Angels County Department of Public Works (LACDPW), 2005.]

\begin{tabular}{lrrcc}
\hline Quarter & $\mathbf{1 9 9 7}$ & $\mathbf{1 9 9 8}$ & $\begin{array}{c}\text { Estimated } \\
\text { average } \\
\text { quarterly } \\
\text { irrigation } \\
\text { (millimeters) }\end{array}$ & $\begin{array}{c}\text { Estimated average } \\
\text { quarterly irrigation } \\
\text { adjusted to 100 percent } \\
\text { pervious land area } \\
\text { (millimeters) }\end{array}$ \\
\hline 1 & 24 & 2 & 17 & 30 \\
2 & 99 & 44 & 71 & 123 \\
3 & 109 & 107 & 108 & 187 \\
4 & 45 & 50 & 46 & 80 \\
\hline Year total & 277 & 204 & 244 & 420 \\
\hline
\end{tabular}


Table 4. Top 10 land-use classes (by area) of the San Fernando Valley, Los Angeles Basin watershed model (LABWM), California.

[Source Southern California Area Governments, 2005. Abbreviations LACDPW, Los Angeles County Department of Public Works; -, not applicable]

\begin{tabular}{|c|c|c|c|c|c|c|}
\hline $\begin{array}{l}\text { LACDPW } \\
\text { land-use } \\
\text { code }\end{array}$ & $\begin{array}{l}\text { LACDPW } \\
\text { land-use } \\
\text { class }\end{array}$ & $\begin{array}{c}\text { Area } \\
\text { (hectares) }\end{array}$ & $\begin{array}{l}\text { Percentage } \\
\text { of total }\end{array}$ & Description & $\begin{array}{c}\text { Contains } \\
\text { irrigated } \\
\text { landscaping }\end{array}$ & $\begin{array}{l}\text { Percentage } \\
\text { pervious }^{1}\end{array}$ \\
\hline 1111 & Residential & 25,148 & 48.7 & High-density single family residential & Yes & 58 \\
\hline 3100 & Vacant & 6,669 & 12.9 & Vacant undifferentiated & No & - \\
\hline 1123 & Residential & 2,864 & 5.6 & $\begin{array}{l}\text { Low-rise apartments, condominiums, and } \\
\text { townhouses }\end{array}$ & Yes & 14 \\
\hline $1223 / 1224$ & Commercial & 1,853 & 3.6 & Modern/older strip development & Yes & 3.5 \\
\hline 1112 & Residential & 1,444 & 2.8 & Low-density single family residential & Yes & 79 \\
\hline 1413 & Transportation & 1,088 & 2.1 & Freeways and major roads & Yes & 9 \\
\hline 1437 & Transportation & 855 & 1.7 & Improved flood waterways and structures & No & - \\
\hline
\end{tabular}

${ }^{1}$ Percentage pervious from Los Angeles County Department of Public Works.

\section{Model Development}

Development of the LABWM consisted of (1) defining the simulation period, including the model initiation and target-simulation periods; (2) defining the spatial (horizontal and vertical) discretization; (3) developing the spatially distributed model parameters representing the physical characteristics of the watershed; (4) developing the temporally and spatially distributed climate inputs; (5) specifying atmospheric parameters for simulating PET; (6) specifying model coefficients used in empirical functions and controls for input and output options; (7) defining boundary conditions; and (8) defining initial conditions. The simulation period used in the INFILv3 code is dependent on the availability of climate data for developing a continuous time series of spatially interpolated daily climate input. Model discretization primarily consisted of developing a gridded representation of the LABWM area, with the grid defining the INFILv3 hydrologic response units as equal-area, square cells. Development of model parameters and climate inputs included compiling and processing available Geographic Information System (GIS) data and daily climate records. Model coefficients included empirical parameters used to model snowmelt and sublimation, to define stream-channel characteristics, and to define precipitation intensity by using specified winter and summer storm durations. Boundary conditions were the daily surface-water inflows from model units upstream from the unit being modeled. Initial conditions were the starting water contents of the root-zone layers, the perched zone, and the snowpack.

\section{Simulation Period}

The LABWM was developed for a 110 year simulation period that started January 1, 1905, and ended October 31, 2014. Continuous daily simulations for multi-year periods prior to January 1, 1905, were problematic because of a sparsity of continuous daily climate records. The simulation period included a 117 month (9.75 year) model-initialization period from January 1, 1905, through September 30, 1914, followed by a 100 -year target-simulation period from October 1, 1914, through September 30, 2014 (water years 19152014). The initialization period is used to mitigate the effects of the initial conditions, which, in this study, were estimated on the basis of values used in previous INFILv3 applications (Hevesi and others, 2003; Rewis and others, 2006; Flint and Martin, 2012; Hevesi and Christensen, 2015). Initial conditions for precipitation-runoff models, including INFILv3, are generally not known and require at least some initialization period to help minimize uncertainties associated with the assumed or estimated initial conditions (Markstrom and others, 2008; Flint and Martin, 2012; Hevesi and Christensen, 2015).

\section{Spatial and Temporal Discretization}

\section{Horizontal Discretization}

Development of the LABWM required the discretization of the model area in a horizontal two-dimensional grid of equal-area (square) cells, which were linked to create a surface-water routing network. The gridded discretization 
was similar to the approach used other models, such as PRMS (Jeton and Maurer, 2011), Topmodel (Beven and Kirkby, 1979), BCM (Flint and Flint, 2007), and GSFLOW (Markstrom and others, 2008; Woolfenden and Nishikawa, 2014), in which discretization was used to represent heterogeneities in the characteristics of the model domain. For this study, the grid-cell geometry was defined by a uniform grid spacing of $201.17 \mathrm{~m}$ in the north-south and east-west directions, and the grid axis was aligned according to the Universal Transverse Mercator, zone 11 projection, using the North American horizontal datum of 1983. The resulting grid covering the 503,877 ha $\left(5,039 \mathrm{~km}^{2}\right)$ area of the LABWM contained a total of 124,722 square grid cells, each cell covering an area of 4.04 ha.

The cascading flow-routing network, used to route runoff and seepage flow, was defined by using the average elevation of each grid cell and the standard eight-directional (D-8), convergent flow-routing method. The $10-\mathrm{m}$ resolution USGS National Elevation Data (NED; www.seamless.gov) was used to define the average elevation of each cell. The grid-cell elevations for the LABWM area ranged from a minimum of $0 \mathrm{~m}$, along the coast, to a maximum of 3,033 $\mathrm{m}$, in the San Gabriel Mountains (fig. 1). The elevations for grid cells in the LAGSA ranged from 0 to $500 \mathrm{~m}$. Higher elevations of 201 to $600 \mathrm{~m}$ were outside of and next to the LAGSA in the Santa Monica Mountains, next to the northern boundary, and in the Palo Verde Hills, along the southwestern boundary (fig. 1). In general, most of the northern and northeastern LAGSA is bounded by higher elevations, creating a peripheral zone of land areas that drain into the LAGSA and likely contribute recharge, as groundwater underflow, to the LAGSA.

In the D-8 method, the flow direction for a given cell is determined by the minimum elevation of the eight adjacent cells. The flow-direction grid defines the connections between upstream and downstream cells as well as the total number of upstream cells for each cell (fig. 8). In the D-8 method, water is allowed to flow diagonally across grid corners to the four cells that are diagonally adjacent to a given cell and therefore do not share a side. For each cell, runoff and seepage is routed to only one downstream cell; however, a given cell can receive inflows from multiple upstream cells (this is also referred to as many-to-one routing). Model cells located on drainage divides do not receive inflows. In the case of cells in flat areas or depressions that are not actual closed basins, the flow direction is determined by known hydrographic features, such as stream lines and watershed divides. For the LABWM, the highresolution 1:24,000 scale National Hydrography Data (NHD) for streams and the Los Angeles County storm-drain map were used in addition to the 10-m NED to define the flow directions to generate the D-8 grid-cell routing network (fig. 8A).

The grid-cell routing network was used to delineate the LABWM into 12 separate INFILv3 model domains (referred to as subdomains) on the basis of drainage divides and the primary drainages affecting the LAGSA (fig. 9). Eight subdomains were used to define the drainage areas most directly affecting the LAGSA (fig. 9): (1) Ballona Creek
(BALC), (2) Dominguez Channel (DOMC), (3) Long Beach (LONG), (4) lower Los Angeles River (LARV), (5) lower San Gabriel River (SGRV), (6) lower Santa Monica Basin (LSMB), (7) Seal Beach (SEAL), and (8) upper Santa Monica Basin (USMB). Either all or large sections of these subdomains were included in the LAGSA and the Los Angeles recharge-study area. Three subdomains were defined by drainages upstream from the LAGSA that either were completely outside the LAGSA or only a small fraction of the total area in the LAGSA: (1) the upper drainage of the Los Angeles River (ULAR), (2) the upper drainage of the San Gabriel River (USGR), and (3) the Rio Hondo drainage (RIOH). A twelfth subdomain, Toponga Creek (TOPC), is outside of the surface-water drainages affecting the LAGSA, but was included for calibration purposes.

\section{Vertical Discretization}

The LABWM was discretized vertically to seven layers, with layers 1 through 6 representing the root zone and an underlying seventh layer, the shallow perched zone, representing a zone of lateral groundwater flow. The discretization of the root zone into six vertical layers was done to account for differences in root density and root-zone water content with depth, as well as differences in the hydraulic conductivity between soil and bedrock. As with previous studies using INFILv3 (Hevesi and others, 2003; Rewis and others, 2006; Flint and Martin, 2012), the thickness of layers for each grid cell in the LABWM was defined on the basis of a combination of the estimated total root-zone thickness and the estimated soil thickness. The top five layers were used to represent the root zone in soil. The sixth model layer was used to represent the root zone in consolidated bedrock where there were thin soils and to designate the hydraulic conductivity of unconsolidated geologic units underlying the soil component for areas of thick soils. Following a previous INFILv3 application to estimate recharge in Big Bear Valley, California (Flint and Martin, 2012), the LABWM used a modified version of INFILv3 that includes a seventh layer representing a shallow perched zone beneath the root zone (fig. 6B).

A primary factor used to determine vertical discretization for layers 1 through 5 was soil thickness, which was estimated on the basis of maps of soils (U.S. Department of Agriculture, 1994) and surficial geology (Jennings, 1977). Areas with thick soils were defined by using the areal extent of alluvial and unconsolidated rock types. The maximum thickness of the root zone was set to $4 \mathrm{~m}$ for these locations. For thinner soils underlain by partially consolidated or consolidated bedrock, both the thickness of the soil layers and the underlying bedrock layer (layer 6) were based on the combination of the estimated soil thickness and the vegetation type assigned to each cell (see Rewis and others, 2006, for a more detailed description). Where soils were estimated to be thin, fewer soil layers with a thickness greater than zero were defined, and a greater thickness was assigned to layer 6 to represent the 


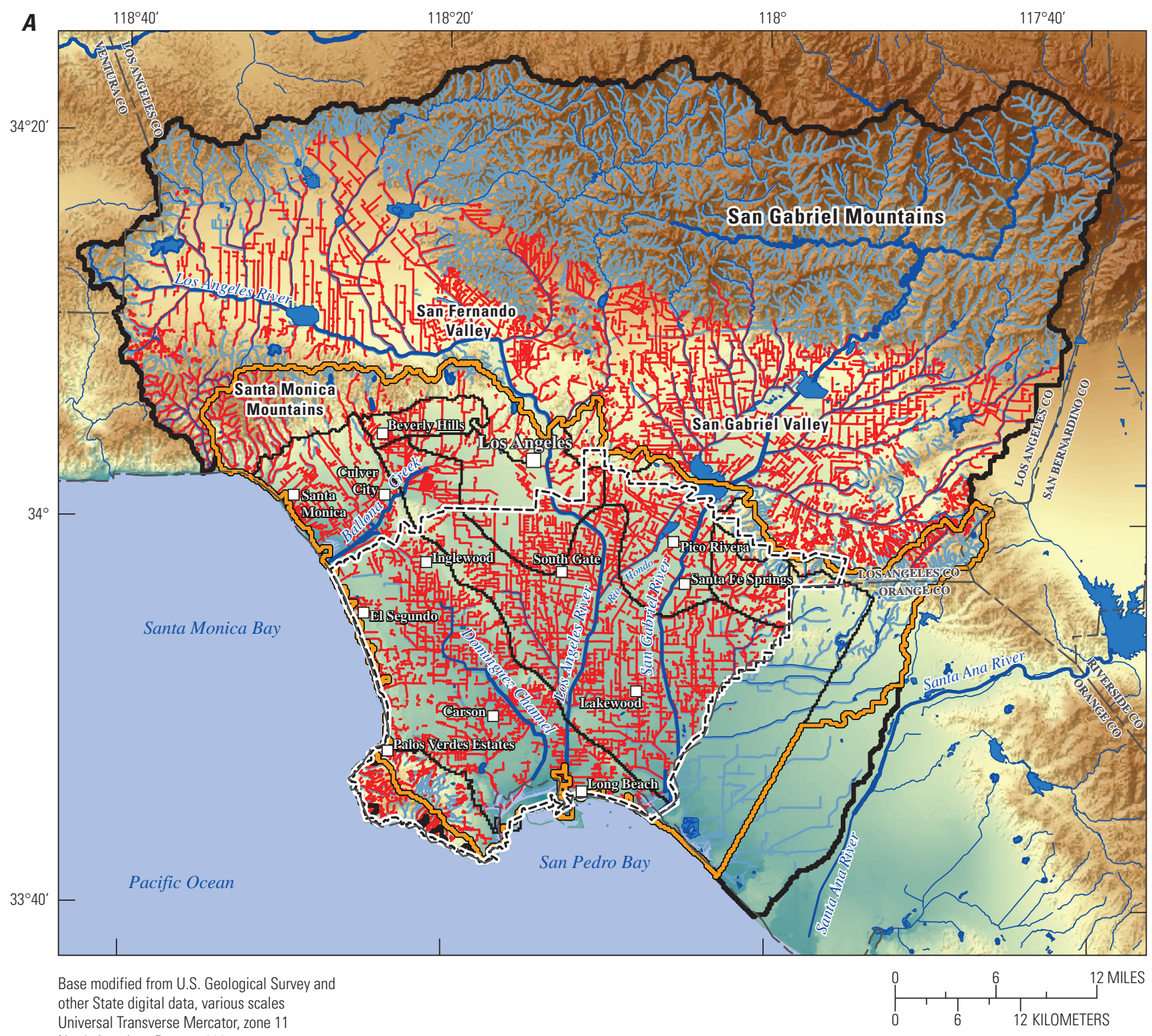

North American Datum 1983

\section{EXPLANATION}

Los Angeles Basin watershed model area boundary

Water Replenishment District

Los Angeles recharge study area

Water bodies and flood-control areas

Major rivers and streams

Minor rivers and streams

— Los Angeles groundwater basins

- - County line

Los Angeles County storm drains

National Hydrography Data streams

Figure 8. Grid-cell flow-routing network, Los Angeles Basin watershed model (LABWM), California: $A$, National Hydrography Data streams and Los Angeles County storm drains used to define the D-8 grid cell routing network; $B$, modeled streamlines as indicated by the number of upstream cells. 


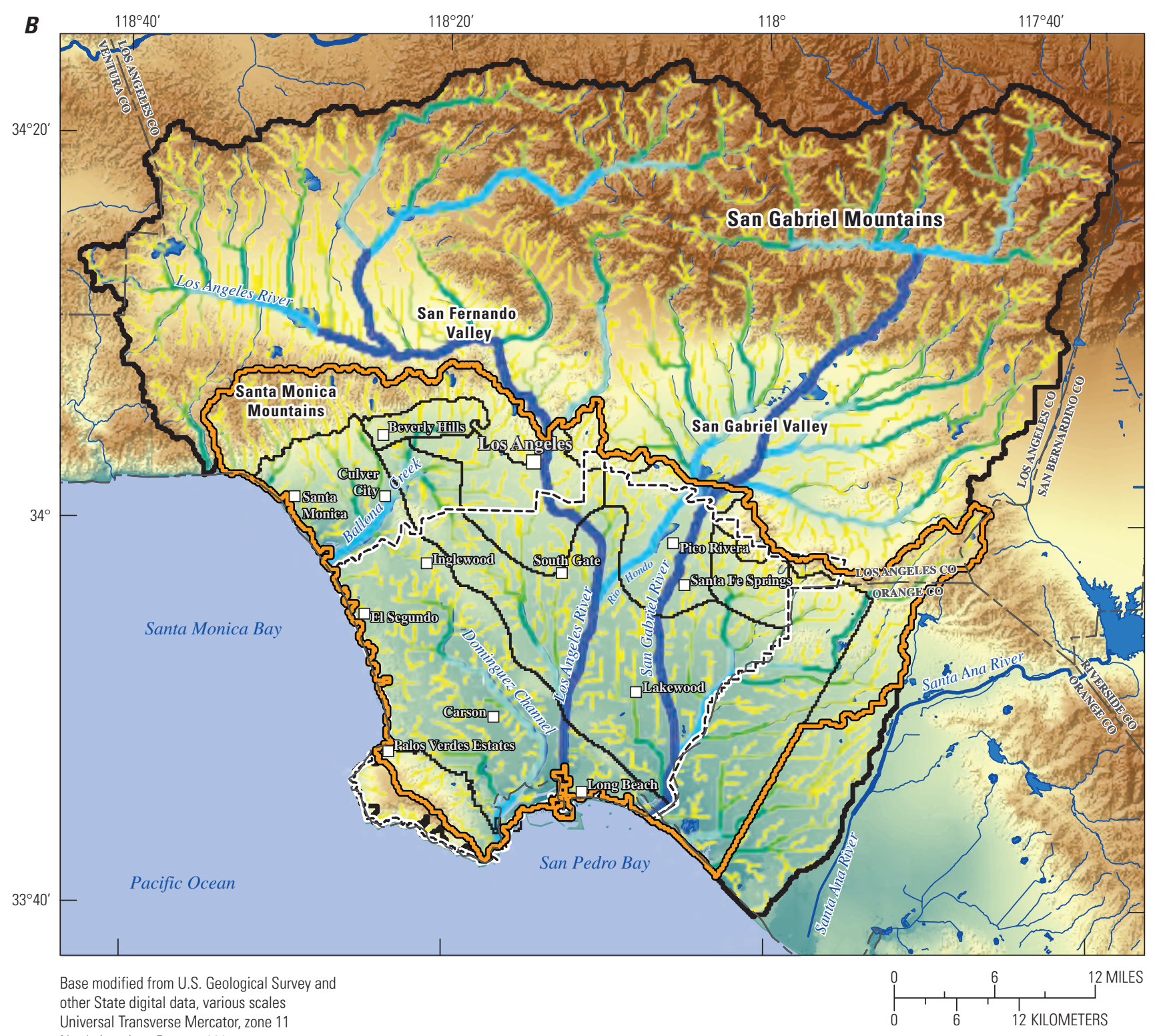

North American Datum 1983

\section{EXPLANATION}

Los Angeles Basin watershed model (LABWM) Modeled streamlines: number of upstream cells
- $21-200$
- 201-500
- $501-1,000$
- $1,001-2,000$
- 2,001-5,000
$5,001-10,000$
$10,001-53,333$

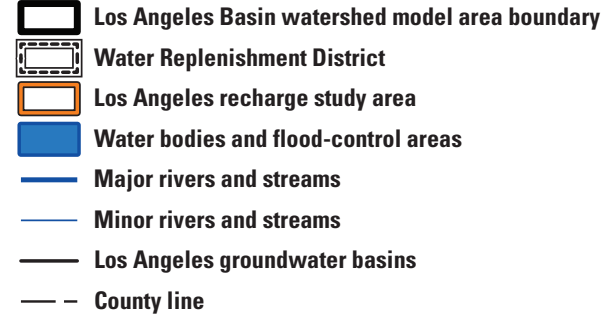

Figure 8. - Continued 




Universal Transverse Mercator, zone 11

North American Datum 1983

EXPLANATION

Los Angeles Basin watershed model subdomains

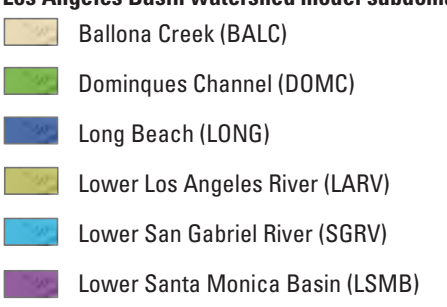

Rio Hondo (RIOH)

Seal Beach (SEAL)

Toponga Creek (TOPC)

Upper Los Angeles River (ULAR)

Upper San Gabriel River (USGR)

Upper Santa Monica Basin (USMB)
Los Angeles Basin watershed model area boundary Water Replenishment District

Los Angeles recharge study area

Water bodies and flood-control areas

Major rivers and streams

Minor rivers and streams

- Los Angeles groundwater basins

- County line

Figure 9. Twelve INFILv3 subdomains included in the Los Angeles Basin watershed model (LABWM), California. 
extension of the root zone into bedrock (roots extending into fractures and weathered zones).

Where the thickness of layer 6 was zero, there was no transpiration from layer 6 . The net-infiltration rate through the soil zone (layers 1-5), however, is limited by the upper hydraulic conductivity assigned to layer 6 . Where the thickness of layer 6 was greater than 0 , the consolidated-rock layer represented by layer 6 was included in the root zone, and transpiration from layer 6 was simulated.

The thickness of the perched zone (layer 7) was dependent on the rock type and was defined by dividing the estimated storage capacity of the perched zone $(0.6096 \mathrm{~m})$ by the effective porosity estimated for layer 6 (layers 6 and 7 were assumed to be the same rock type underlying the root zone). The storage capacities of the six root-zone layers and the perched-zone layer were calculated by using layer thickness and the estimated layer porosity. The storage capacities were expressed as a uniform depth and defined the maximum amount of water stored in each layer and available for ET. Layer thicknesses and storage capacities are discussed in more detail in the "Model Inputs" section.

\section{Spatially Distributed Model Parameters}

Spatially distributed watershed parameters represent the physical characteristics of the drainages being modeled, including the land surface, the root zone, and the shallow perched zone. Spatially distributed parameters included (1) topographic parameters, (2) land-cover parameters, (3) vegetation and root-zone parameters, (4) soil parameters, and (5) geohydrologic parameters.

\section{Topographic Parameters}

In addition to the grid-cell elevations and flow-routing parameters discussed previously, the topographic parameters included a set of parameters required for the simulation of PET. The topographic parameters included land-surface slope, aspect, a set of 36 blocking ridge angles, and a skyview parameter. Elevation, slope, aspect, and shading parameters were used to simulate incoming solar radiation and the netradiation energy balance on an hourly basis, which was then used to simulate PET (Flint and Childs, 1987). Cell elevation was also used to simulate seepage flow. The 36 blocking ridge angles were calculated at each 10 degree azimuth direction for each cell and were used to model the effects of shading from surrounding terrain, which can greatly reduce PET in rugged areas (Flint and Childs, 1987). The blocking ridge angles defined the sunrise and sunset times for the 1-hour time step used in the PET simulation. The blocking ridge angles were used to calculate the skyview parameter, which defined the reduction in refracted clear-sky solar radiation caused by the surrounding terrain. In general, simulated PET was much less for higher elevation, north-facing slopes compared to lower elevation, south-facing slopes, and PET was greater for summit areas compared to valleys surrounded by high ridges.

The 10-meter resolution USGS NED data (http://www. seamless.gov) used to develop the flow-routing network were also used to define the topographic parameters for each grid cell. Land-surface slope and aspect were calculated by using GIS as the average slope and aspect of all 10-meter NED cells in the area of each 201-m LABWM cell (figs. 10, 11). The calculated slope ranged from a minimum of 0 degrees, for many cells in the Los Angeles Basin, to a maximum slope of 41.3 degrees, in the San Gabriel Mountains (fig. 10). The average slope for the LABWM area was 6.3 degrees. Almost half of all cells either had an aspect in the range of 157.51 to 202.5 degrees (south), calculated for 25 percent of all cells, or in the range of 202.51 to 247.5 degrees (southwest), calculated for 22 percent of all cells in the LABWM area (fig. 11).

\section{Land Cover Parameters}

Input for the LABWM included two parameters representing land-cover characteristics: (1) percentage of imperviousness and (2) percentage of plant-canopy cover (vegetation density). The imperviousness percentage is defined as the percentage of the cell area that was covered by an artificial impervious surface (for example, a roadway, rooftop, or parking lot). The average imperviousness was estimated by using the 2001 National Land Cover Data (NLCD), which has a grid resolution of $30 \mathrm{~m}$ (U.S. Geological Survey, 2005). The average imperviousness for the LABWM domain was 33.7 percent (fig. 12). Maximum imperviousness values of 99 percent were obtained for the highly developed areas, such as downtown Los Angeles. Minimum values of 0 percent imperviousness were obtained for the mountainous headwater regions in the San Gabriel and Santa Monica Mountains.

Estimates of the percentage of plant-canopy cover were calculated by using the 2001 NLCD 30-meter forestcanopy map (U.S. Geological Survey, 2001). The percentage of canopy cover is defined as the percentage of land area covered by natural forest canopy. Forest canopy does not represent urban or agricultural landscapes. A maximum forest canopy cover of 73 percent was obtained for the San Gabriel Mountains, and an average value of 9.7 percent was obtained for the LABWM area (fig. 13). Forest-canopy values of 0 percent were obtained for most of the developed and urbanized lowland areas of the Los Angeles Basin and the San Fernando Valley, including much of the area in the Los Angeles recharge-study area (area contributing recharge to the LAGSA). 


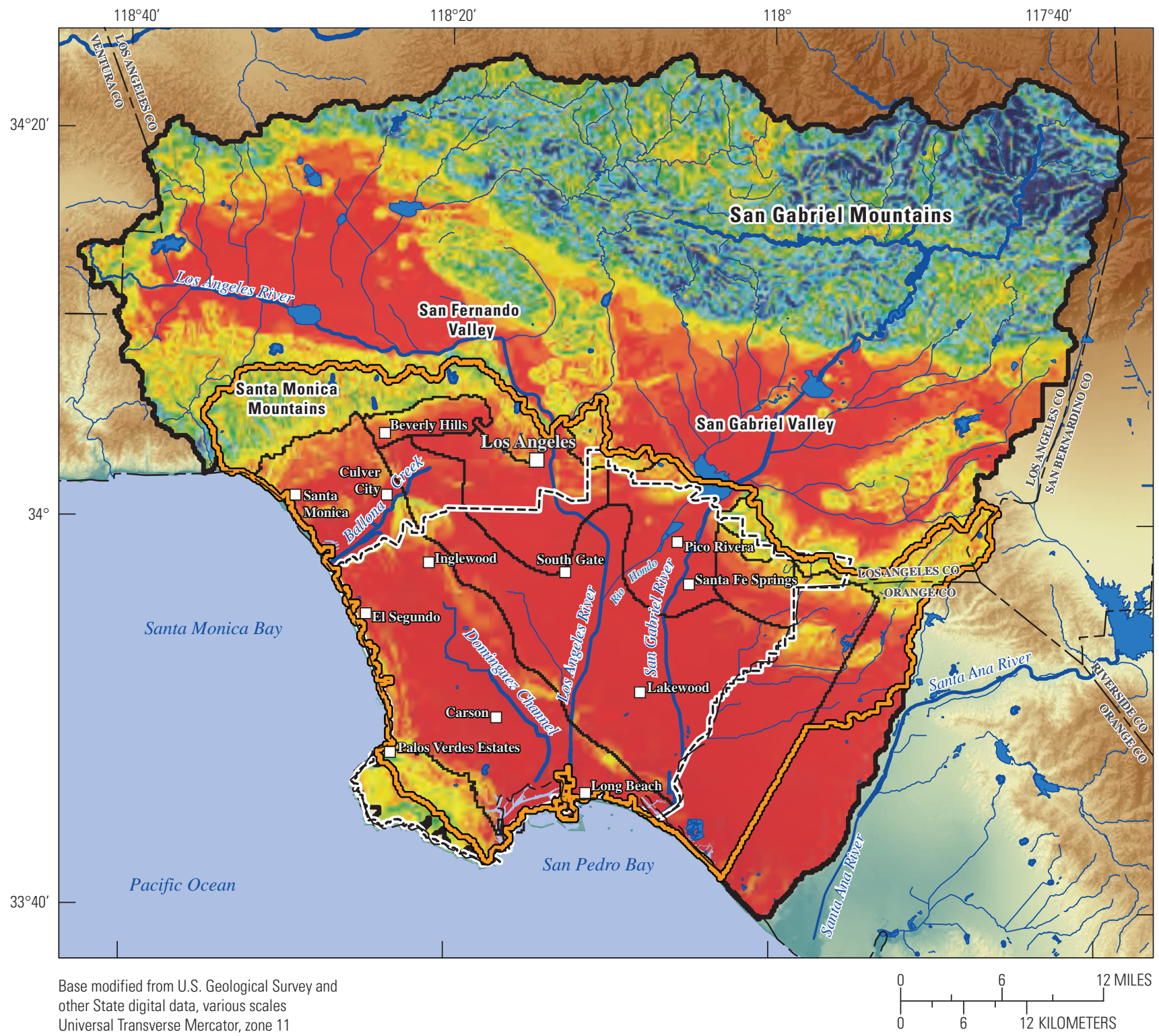

North American Datum 1983

EXPLANATION

\begin{tabular}{|c|c|c|}
\hline \multicolumn{2}{|c|}{ Land-surface slope (in degrees) } & Los Angeles Basin watershed model area boundary \\
\hline $0.0-1.0$ & $12.1-16.0$ & Water Replenishment District \\
\hline $1.1-2.0$ & | $16.1-20.0$ & Los Angeles recharge study area \\
\hline $2.1-4.0$ & $20.1-24.0$ & Water bodies and flood-control areas \\
\hline $4.1-8.0$ & $24.1-28.0$ & Major rivers and streams \\
\hline $8.1-12.0$ & $28.1-41.0$ & $\begin{array}{l}\text { Los Angeles groundwater basins } \\
\text { County line }\end{array}$ \\
\hline
\end{tabular}

Figure 10. Average land-surface slope, Los Angeles Basin watershed model (LABWM), California. 


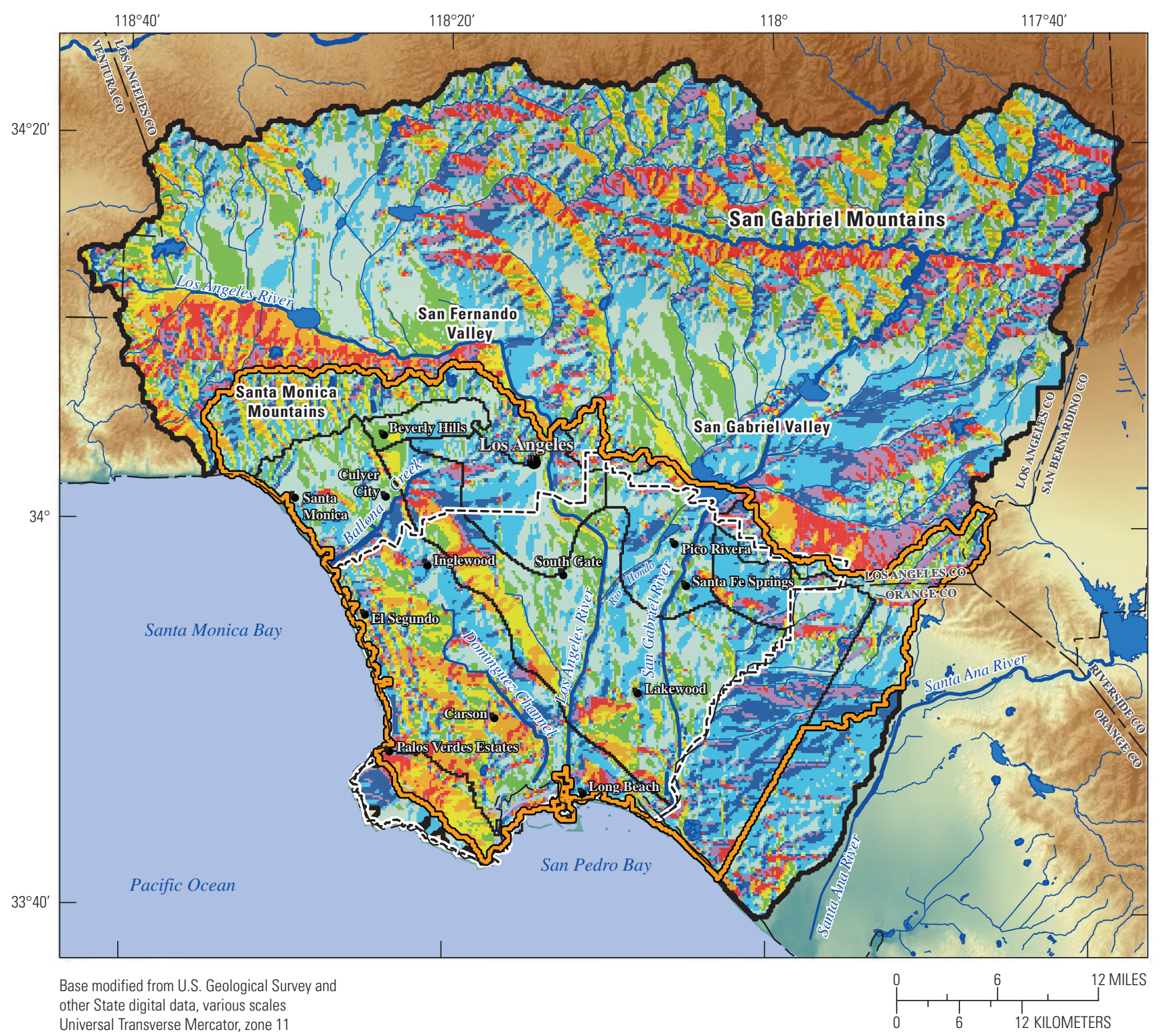

Universal Transverse Mercator, zone 11

North American Datum 1983

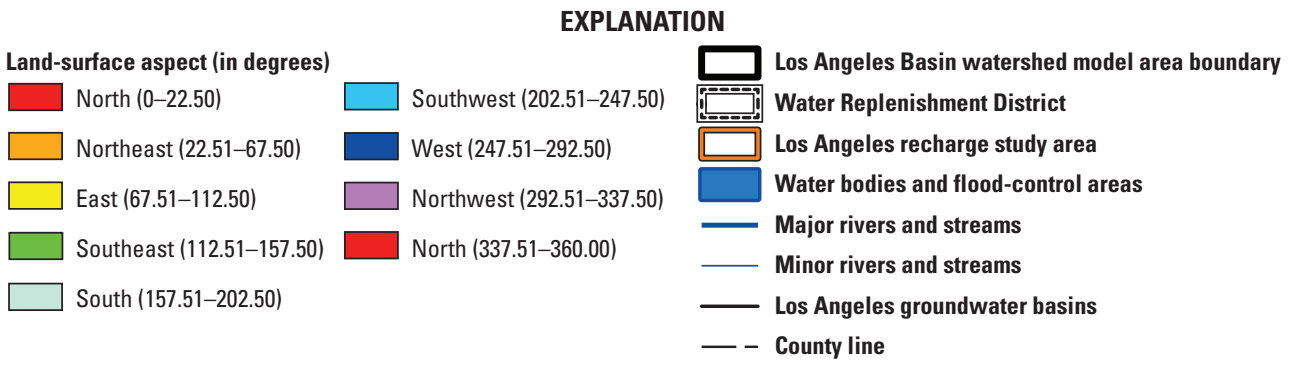

Figure 11. Average land-surface aspect, Los Angeles Basin watershed model (LABWM), California. 


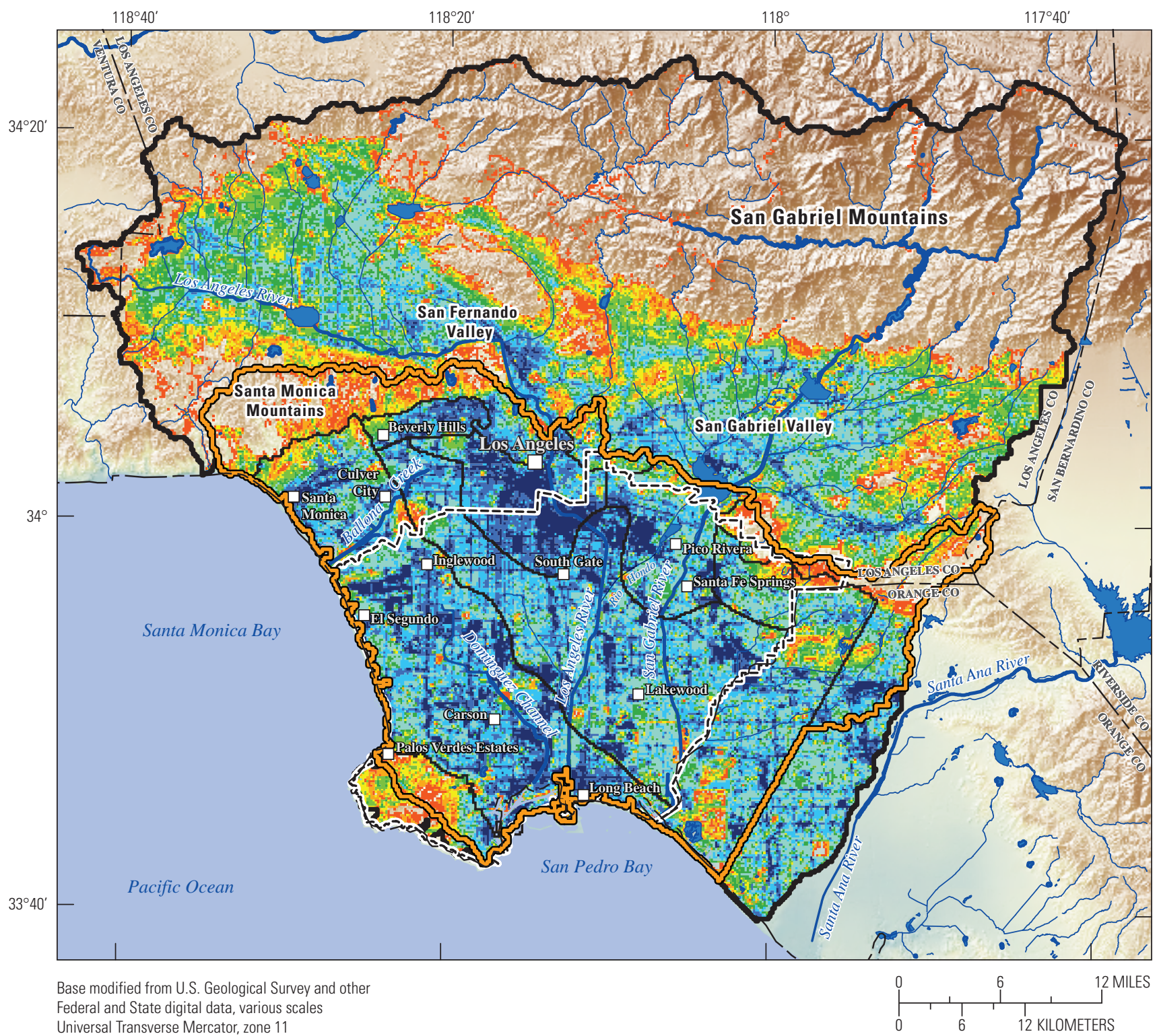

Universal Transverse Mercator, zone 11

North American Datum 1983

\section{EXPLANATION}

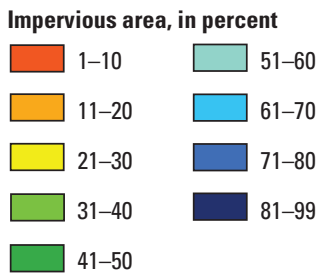

Los Angeles Basin watershed model area boundary

Water Replenishment District

Los Angeles recharge study area

Water bodies and flood-control areas

Major rivers and streams

- Minor rivers and streams

L Los Angeles groundwater basins

- - County line

Figure 12. Percentage of impervious area, Los Angeles Basin watershed model (LABWM), California. 


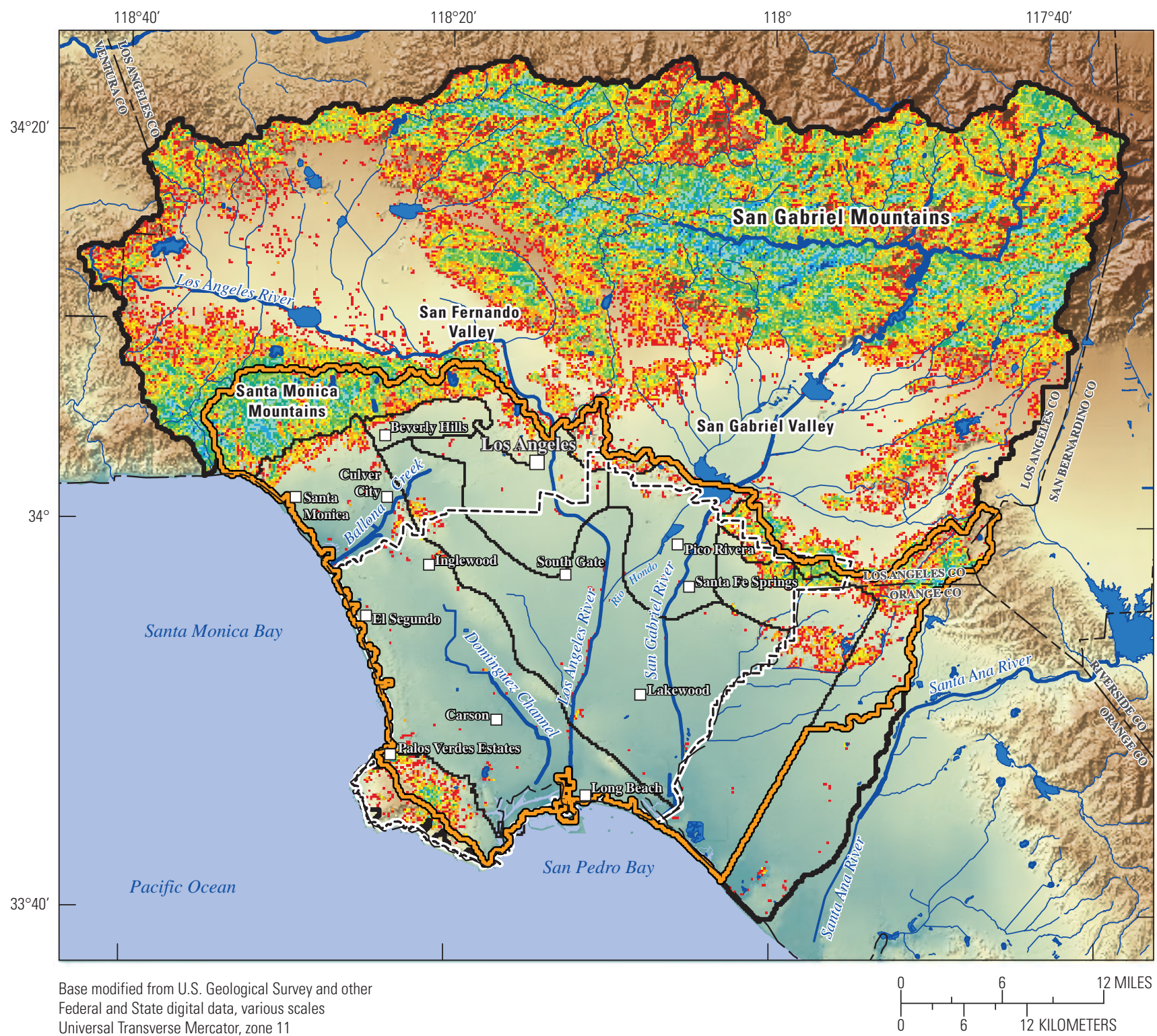

Universal Transverse Mercator, zone 11

EXPLANATION

\begin{tabular}{|c|c|c|}
\hline \multicolumn{2}{|c|}{ Forest canopy cover, in percent } & Los Angeles Basin watershed model area boundary \\
\hline $1-8$ & $41-48$ & Water Replenishment District \\
\hline $9-16$ & $49-56$ & Los Angeles recharge study area \\
\hline $17-24$ & $57-64$ & $\begin{array}{l}\text { Water bodies and flood-control areas } \\
\text { Major rivers and streams }\end{array}$ \\
\hline $25-32$ & $65-73$ & Minor rivers and streams \\
\hline $33-40$ & & $\begin{array}{l}\text { Los Angeles groundwater basins } \\
\text { County line }\end{array}$ \\
\hline
\end{tabular}

Figure 13. Percentage of forest-canopy cover, Los Angeles Basin watershed model (LABWM), California. 


\section{Vegetation and Root-Zone Parameters}

Vegetation and land-use type were used to help define the thickness of root-zone layer 6 and root density for all layers of the root zone. In general, a thicker root zone and greater root densities are assigned to denser vegetation types (for example, forested areas and residential urban areas). Vegetation and land-use types were defined by using the California Land Cover Mapping and Monitoring Program (CLCMMP) whrtyp vegetation data (http://frap.cdf.ca.gov/projects/land_cover/ index.html). The whrtyp attribute used by the CLCMMP is based on the California Wildlife Habitat Relationships System (CWHR) classification of existing vegetation types important to wildlife (http://www.dfg.ca.gov/biogeodata/). This system was developed to recognize and logically categorize major plant communities at a scale sufficient to predict wildlifehabitat relationships (California Department of Fish and Wildlife, 2014). A total of 31 different vegetation and landuse types were identified for the LABWM domain (fig. 14; table 5). The most common vegetation and land-use types were urban (map number 8), assigned to 73,864 cells, and mixed chaparral (map number 1), assigned to 22,103 cells. The least common vegetation type was wet meadow (map number 19), assigned to one cell.

\section{Soil Parameters}

Soil parameters were estimated for each model cell by using the State Soil Geographic Database (STATSGO) digital map and associated attribute tables compiled by the U.S. Department of Agriculture (1994). A total of 18 different soil types, or soil map units, were defined by the STATSGO data (fig. 15; table 6). The soil parameters included several physical and hydraulic properties based on the STATSGO data (Hevesi and others, 2003): soil porosity, wilting-point (residual) water content, soil depth, a drainage-function coefficient, and vertical saturated hydraulic conductivity. Soil depth, porosity, and the wilting point defined the root-zone storage capacities that were used to simulate transpiration from the five soil layers. The relative saturation of each rootzone layer-calculated by using the simulated water content and the maximum storage capacity of each layer-along with the vertical saturated hydraulic conductivity and the drainagefunction coefficient for each layer were used to simulate drainage and ET for each layer.

The soil parameters used in the LABWM were the weighted average values of the soil components and layers associated with each STATSGO map-unit identifier (MUID). The MUID assigned to each LABWM cell was the MUID with the maximum area within each cell. For the LABWM domain, the maximum soil porosity was 0.43 , and minimum porosity was 0.35 (table 6). The porosities of 0.4 and greater were in the area of the Palos Verdes Hills and in the higher elevations of the San Gabriel and Santa Ana Mountains. These higher porosities were likely due to more organic matter in these soils, which were generally in the more heavily vegetated areas. The lowest porosities, 0.348 to 0.35 , were along the coastal region of the Los Angeles Basin and were likely associated with soils that had a high percentage of sand. The maximum and minimum wilting-point values were 0.18 and 0.01 , respecitvely (table 6). The upper vertical saturated hydraulic conductivity values varied from a maximum of 5,747 millimeters per day ( $\mathrm{mm} /$ day) to a minimum of $202 \mathrm{~mm} /$ day, and the lower vertical saturated hydraulic conductivity varied from a maximum of $1,280 \mathrm{~mm} /$ day to a minimum of $70 \mathrm{~mm} /$ day (table 6). The soils with higher hydraulic conductivities were in the coastal areas (where the soils are likely sandier) and in the higher elevations of the San Gabriel Mountains.

\section{Geohydrologic Parameters}

Parameters representing the geohydrologic properties of geologic materials (consolidated and unconsolidated rock types) underlying the soil zone were estimated for each of the 24 different geologic map units defined by Jennings (1977) that are in the LABWM area (fig. 16; table 7). The parameters included layer- 6 effective porosity, layer-6 upper and lower saturated hydraulic conductivity, and layer-7 hydraulic conductivity and thickness (table 7). Estimates of effective porosity and upper and lower saturated hydraulic conductivity were based on a general knowledge of the characteristics of the different geologic units. For example, unconsolidated deposits were assumed to have a greater effective porosity and saturated hydraulic conductivity compared to consolidated rocks, and sedimentary rocks were assumed to have greater saturated hydraulic conductivity relative to igneous and metamorphic rocks (Hevesi and others, 2003; Flint and Martin, 2012). The thickness of the shallow, perchedgroundwater zone (layer 7) was defined by assuming a storage capacity of $0.6096 \mathrm{~m}$ and then using the estimated effective porosity to calculate a thickness for layer 7 .

The combined thickness of root-zone layers 1 through 5 was defined by the estimated soil thickness. Soil thickness first was estimated by using the map of surficial geology (indicating consolidated-rock types and unconsolidated sediments) to locate unconsolidated sediments (mostly alluvium), which were associated with thick soils. The root-zone soil thickness was set to $4 \mathrm{~m}$ for thick soils. The STATSGO soil-type map then was used to define the soil thickness for all areas mapped as a consolidated-rock type. The resulting soil-thickness map varied from minimum values of less than $0.3 \mathrm{~m}$ in rugged, upland areas to maximum values of 1.5-4 $\mathrm{m}$ in the low-lying areas mapped as having thick alluvium (fig. 17). 


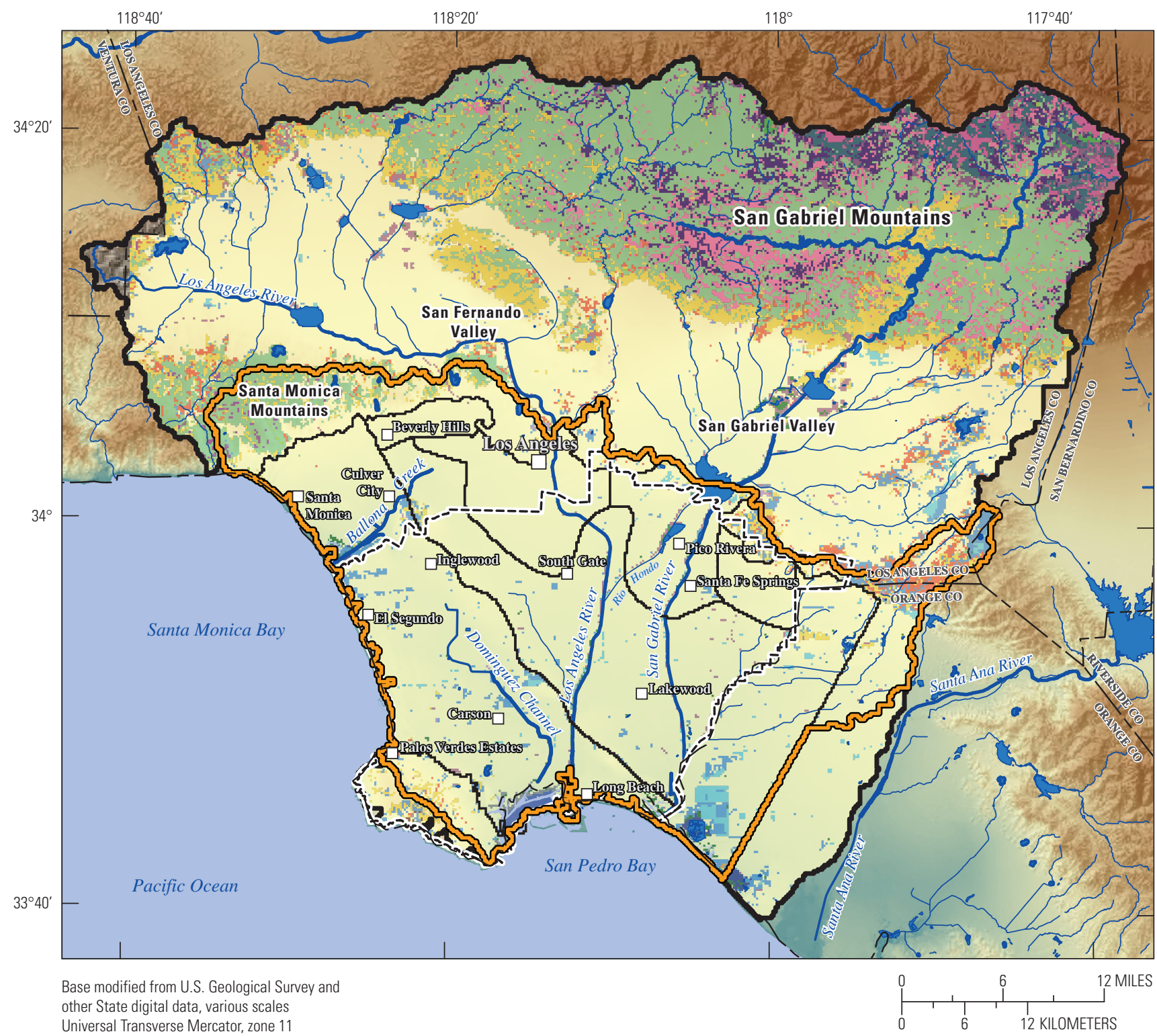

Universal Transverse Mercator, zone 11 North American Datum 1983

\section{EXPLANATION}

Vegetation and land-cover classification

$\square$ Mixed chaparral
$\square$ Chamise-redshank chaparral
$\square$ Coastal oak woodland
$\square$ Annual grass
$\square$ Coastal scrub
$\square$ Barren
$\square$ Valley oak woodland
$\square$ Urban
$\square$ Montane riparian
$\square$ Water

$\square$ Agriculture-crops
$\square$ Unknown
$\square$ Saline emergent wetland
$\square$ Desert wash
$\square$ Valley foothill riparian
$\square$ Eucalyptus
$\square$ Perennial grass
$\square$ Montane hardwood
$\square$ Wet meadow
$\square$ Desert scrub

Eastside pine

$\square$ Jeffrey pine

Montane hardwoods conifer

Montane chaparral

Sierran mixed conifer

$\square$ Sagebrush

$\square$ Ponderosa pine

Subalpine conifer

Freshwater emergent wetland

Closed cone pine-cypress

Alkali scrub
Los Angeles Basin watershed model area boundary

Water Replenishment District

$\square$ Los Angeles recharge study area

Water bodies and flood-control areas

Major rivers and streams

Minor rivers and streams

- Los Angeles groundwater basins

- County line

Figure 14. Vegetation type, Los Angeles Basin watershed model (LABWM), California. 
Table 5. Table of vegetation parameters (layers 1-6), Los Angeles Basin watershed model (LABWM), California.

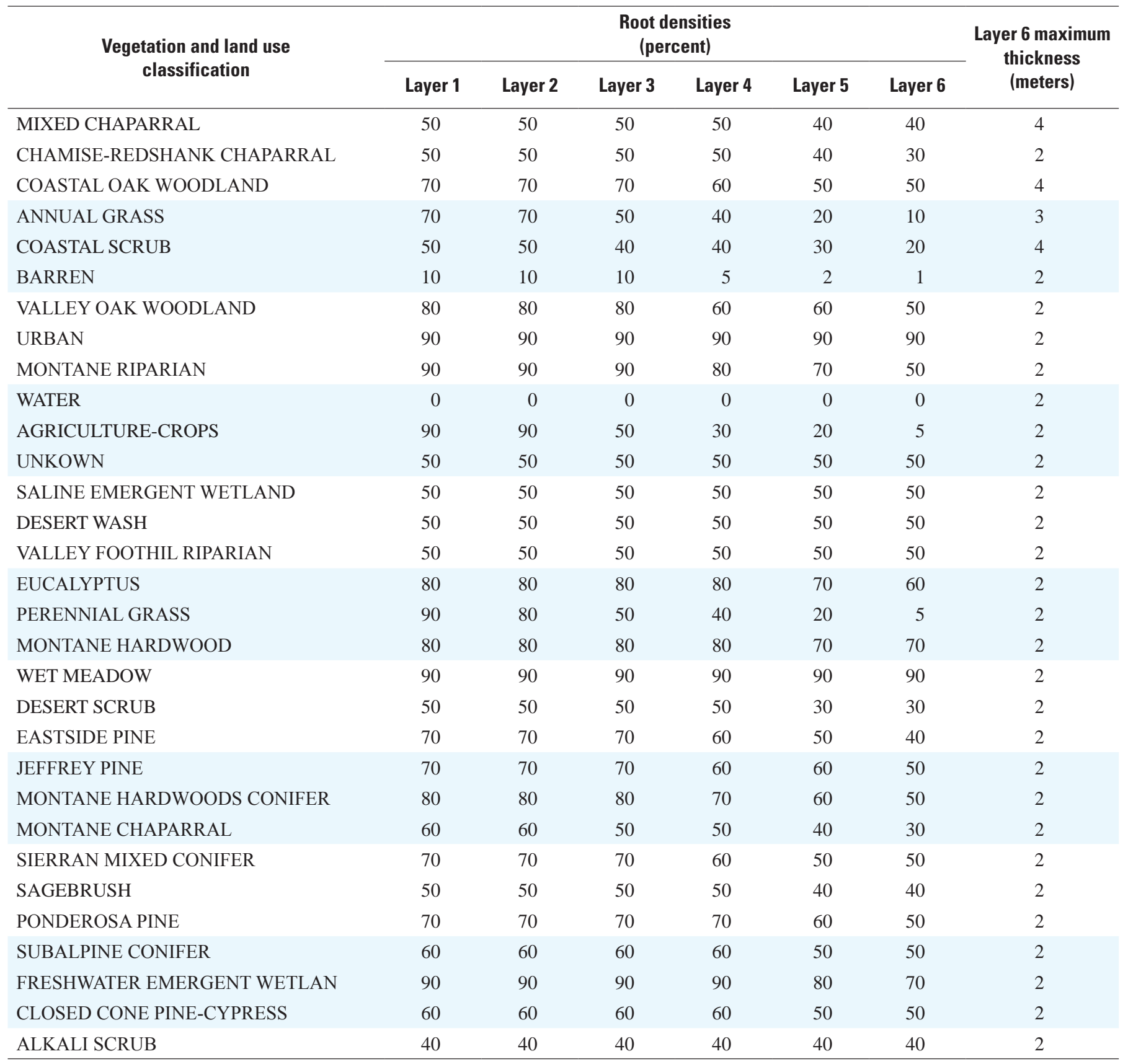




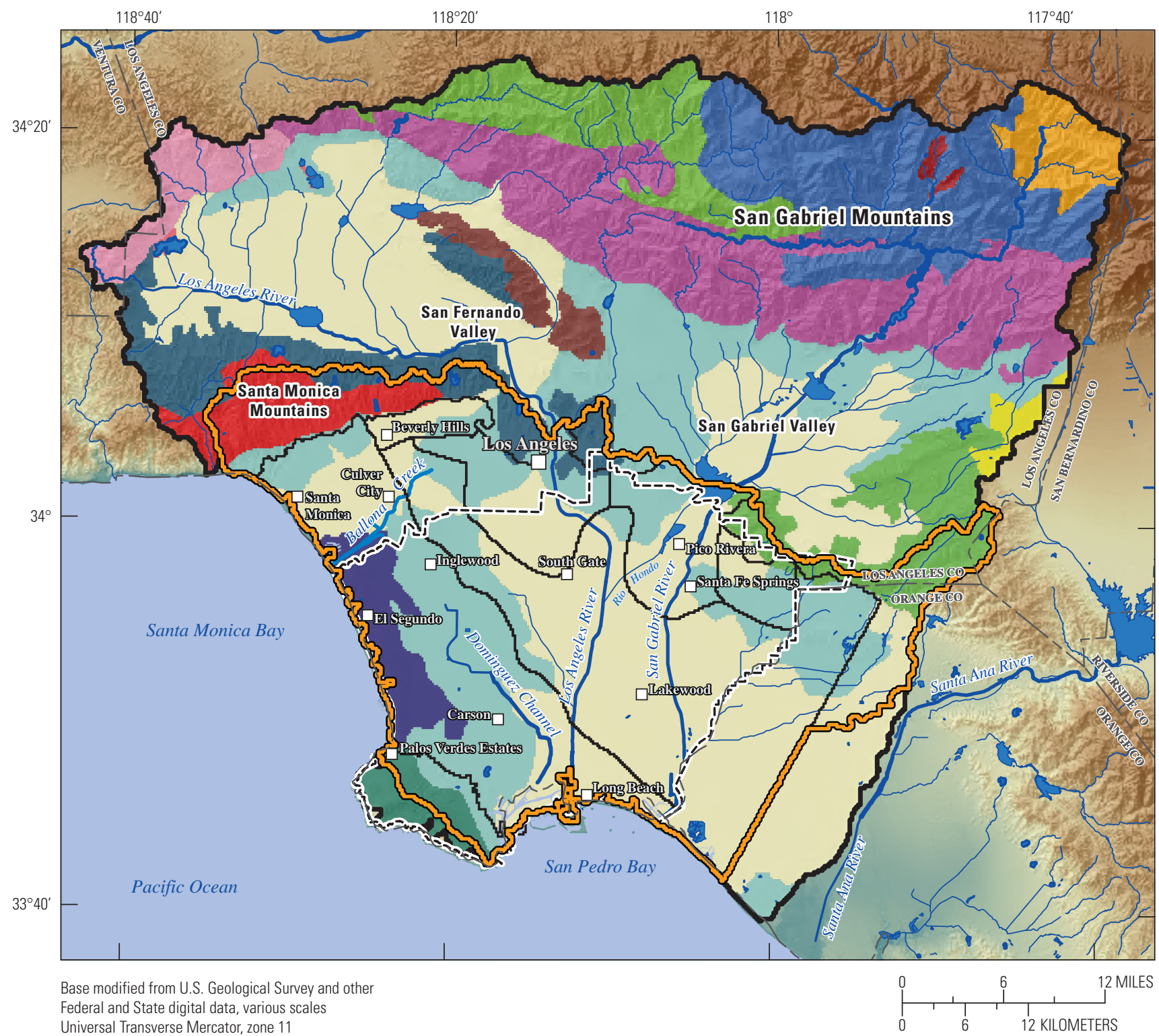

Universal Transverse Mercator, zone 11

EXPLANATION

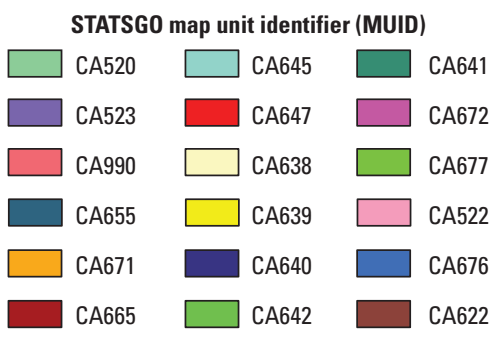

\begin{tabular}{l} 
Los Angeles Basin watershed model area boundary \\
Water Replenishment District \\
Los Angeles recharge study area \\
Water bodies and flood-control areas \\
Major rivers and streams \\
\hline Minor rivers and streams \\
\hline Los Angeles groundwater basins \\
\hline- County line
\end{tabular}

Figure 15. Soil type, Los Angeles Basin watershed model (LABWM), California. 
Table 6. Table of soil parameters, model layers 1-5, Los Angeles Basin watershed model (LABWM), California. [mm/day, millimeter per day]

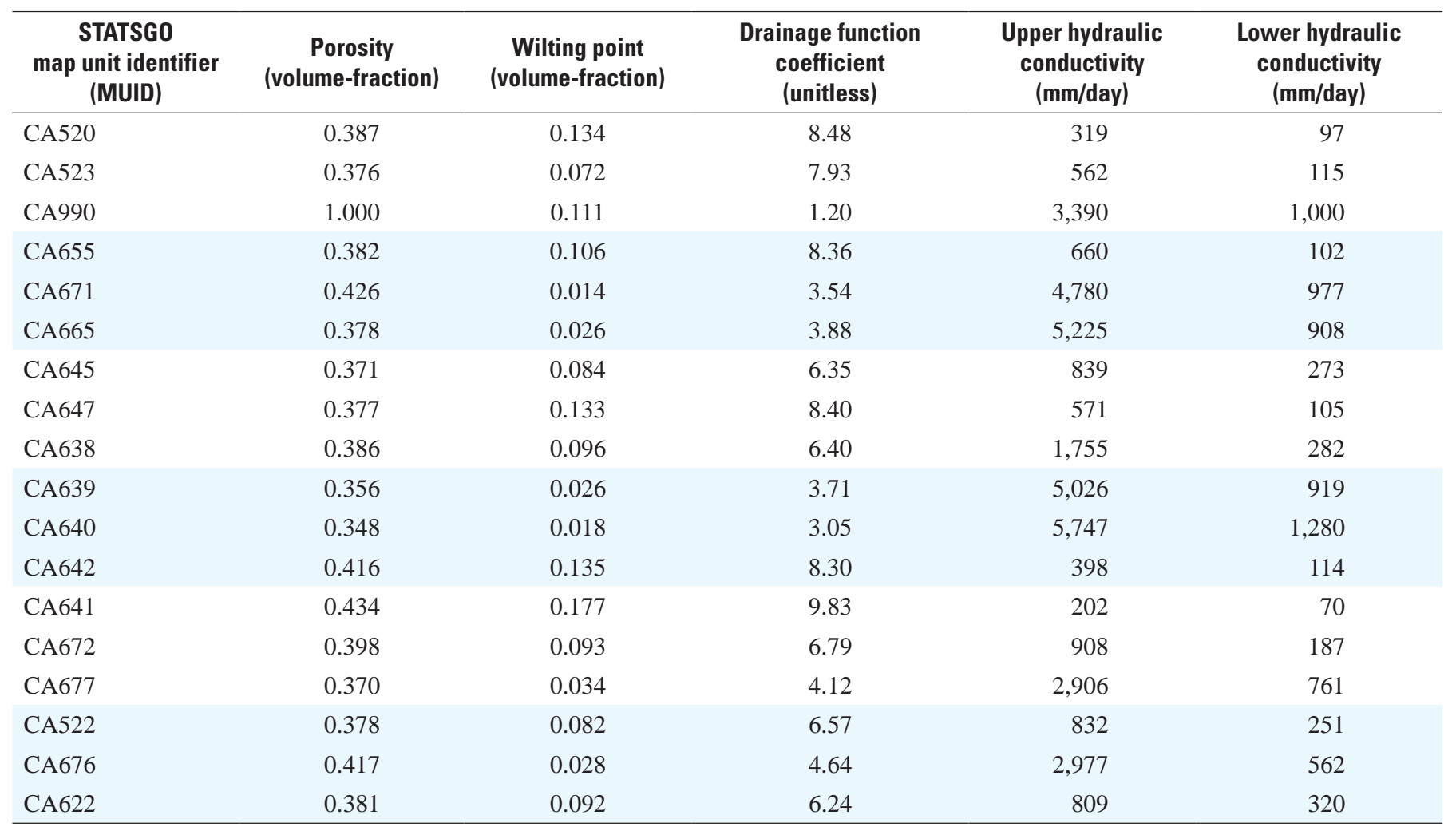




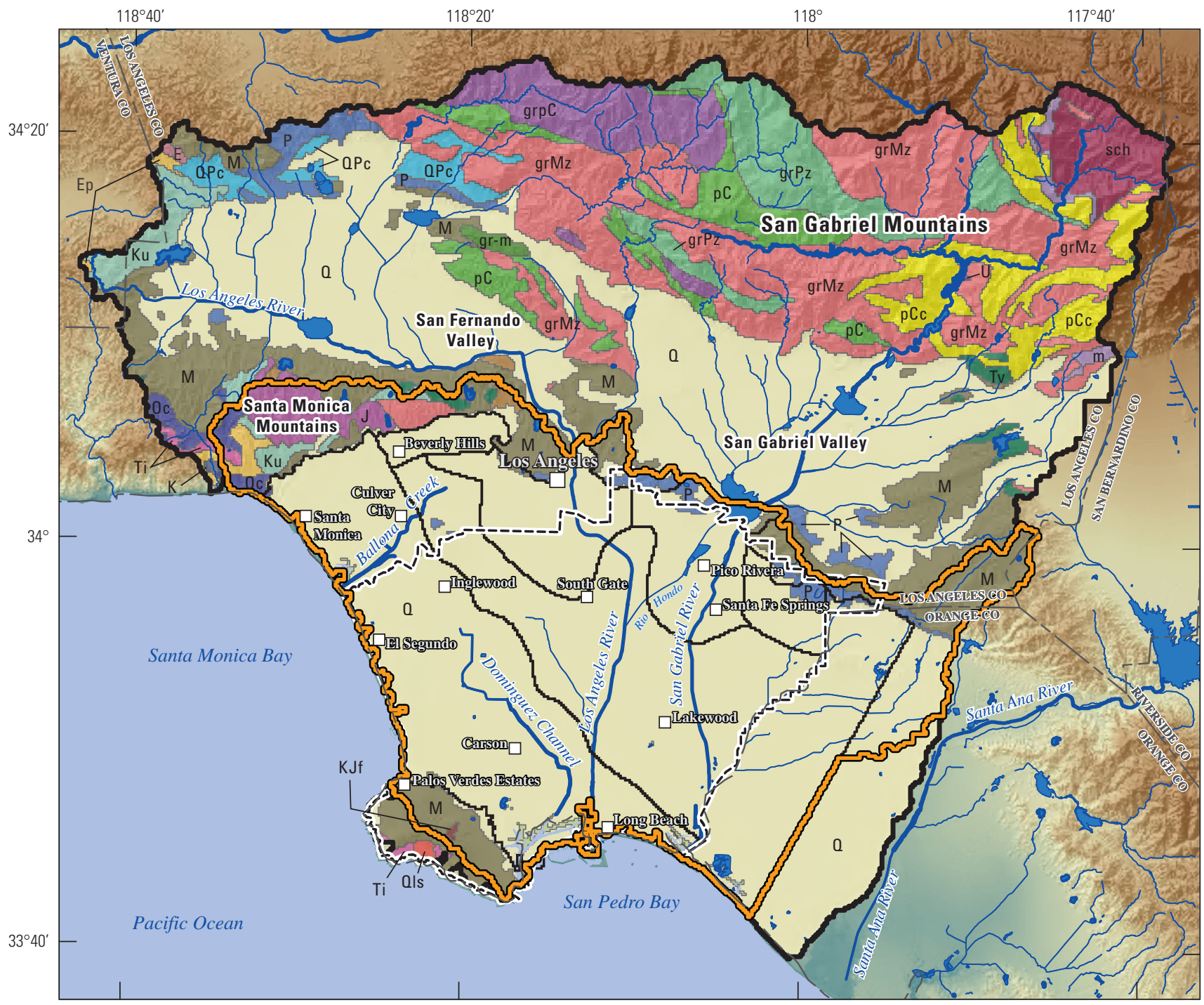

Base modified from U.S. Geological Survey and other State digital data, various scales Universal Transverse Mercator, zone 11 North American Datum 1983

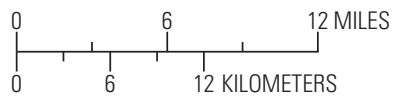

\section{EXPLANATION}

\section{Rock descriptions}

$\mathrm{U}$ Undefined deposits

0 Quaternary-sedimentary deposits

QPC Quaternary-continential sedimentary deposits

Qls Quaternary-continential sedimentary deposits

M Late Tertiary-marine sedimentary rock

$\mathrm{P}$ Late Tertiary-marine sedimentary rock

Ep Early Tertiary-marine sedimentary rock

E Early Tertiary - marine sedimentary rock

Oc Tertiary-continential sedimentary rock

Tv Tertiary-volcanic rock

$\mathrm{Ti}$ Tertiary—volcanic rock

$\mathrm{Ku}$ Cretaceous-marine sedimentary rock

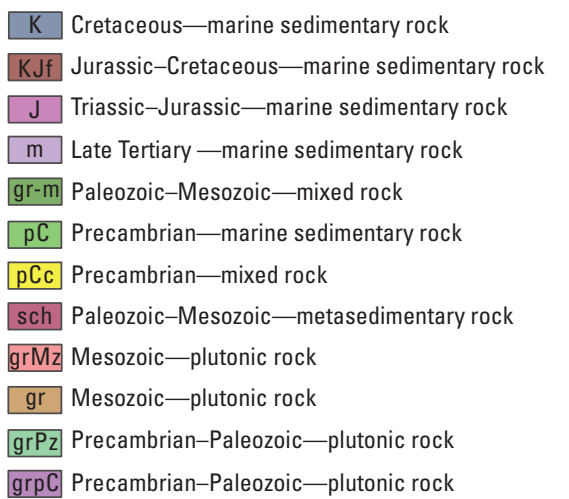

Los Angeles Basin watershed model area boundary

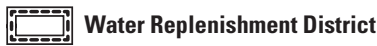

Los Angeles recharge study area

Water bodies and flood-control areas

Major rivers and streams

Minor rivers and streams

- Los Angeles groundwater basins

- - County line

Figure 16. Rock types used as input for the Los Angeles Basin watershed model (LABWM), California. 
Table 7. Geologic parameters (layers 6-7), Los Angeles Basin watershed model (LABWM), California.

[Data source Jennings, C.W., 1977, Geologic map of California, California Division of Mines and Geology, Geologic Data Map no. 2, scale 1:750,000 Abbreviations HRU, hydrologic response unit; mm/day, millimeter per day; —, not applicable]

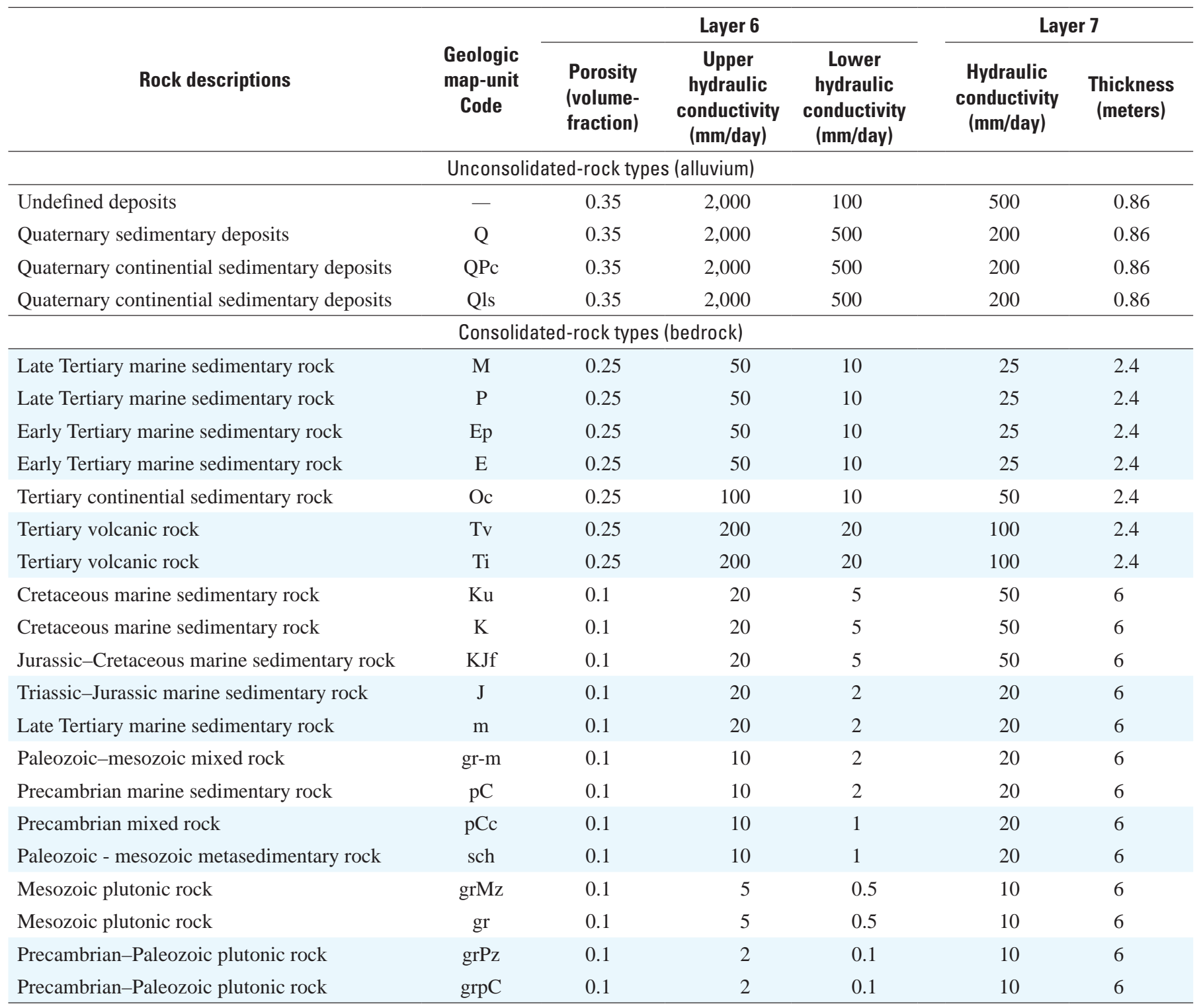




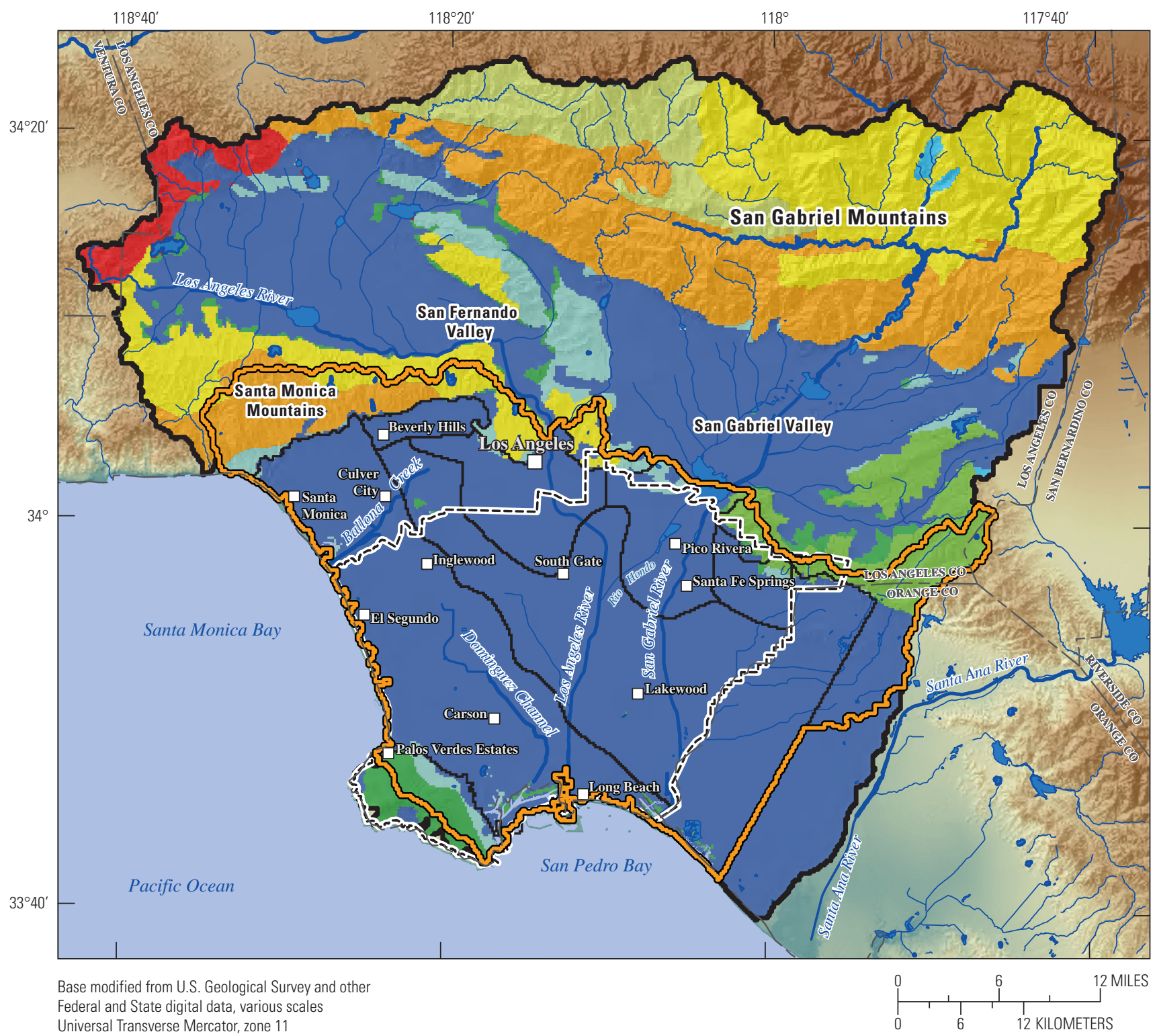

Universal Transverse Mercator, zone 11

EXPLANATION

Soil thickness, in centimeters

$\begin{array}{ll}\square \text { 0-10 } & \square>54-77 \\ \square>10-32 & \square>77-91 \\ \square>32-40 & \square>91-105 \\ \square>40-49 & \square>105-149 \\ \square>49-54 & \square>149-400\end{array}$

\begin{tabular}{l} 
Los Angeles Basin watershed model area boundary \\
Water Replenishment District \\
Los Angeles recharge study area \\
Water bodies and flood-control areas \\
Major rivers and streams \\
Minor rivers and streams \\
$\square-$ Los Angeles groundwater basins \\
\hline- County line
\end{tabular}

Figure 17. Estimated soil thickness, Los Angeles Basin watershed model (LABWM), California. 
The total root-zone thickness is defined by the estimated thickness of the soil zone (layers 1-5) plus the estimated thickness for layer 6. Layer-6 thickness was estimated by using a combination of the soil-thickness map and the vegetation-type map. Layer-6 thickness varied from minimum values of zero in areas of thick soils overlying unconsolidatedrock types to a maximum thickness of $4 \mathrm{~m}$ on the lower slope of the San Gabriel Mountains (fig. 18). For upland areas with thin soils underlain by consolidated rock types, layer- 6 thickness varied from $0.001 \mathrm{~m}$ to $4 \mathrm{~m}$, depending on soil thickness and vegetation type.

The root-zone storage capacity was calculated by using the total thickness of the root zone (soil layers and layer 6 combined), the porosity and wilting point of the soil layers, and the effective porosity of layer 6 . The root-zone storage capacity is the maximum amount of water that can be stored in the root zone and available for evapotranspiration. For the LABWM area, the estimated root-zone storage capacity varied from a minimum of $200 \mathrm{~mm}$ to a maximum of 3,555 mm (fig. 19). For most lowland areas with thick soils, the rootzone storage capacity varied from 1,000 to $1,200 \mathrm{~m}$. For most upland areas with thinner soils underlain by consolidated rock types, the root-zone storage capacity varied from 200 to $600 \mathrm{~mm}$.

\section{Climate Inputs}

As part of the daily water-balance simulation, the LABWM calculates a unique time series of daily precipitation and maximum and minimum air temperature for each model. The inputs required for the spatial interpolation are daily climate records for a network of climate stations and estimates of average monthly precipitation and maximum and minimum air temperature for each climate station and for all model cells (Hevesi and others, 2003; Flint and Martin, 2012; Hevesi and Christensen, 2015). The daily climate inputs consisted of precipitation and maximum and minimum air temperature and were used with the average monthly estimates for precipitation and maximum and minimum air temperature to spatially interpolate the daily inputs for the LABWM domain by using a modified inverse-distance-squared interpolation method (Hevesi and others, 2003; Flint and Martin, 2012).

Daily climate data consisting of precipitation and maximum and minimum daily air temperature were available from a network of 201 climate stations in southern California centered in the LABWM domain (figs. 20, 21; table 2).

Records from these stations are collected and stored by two different agencies: the National Climatic Data Center (NCDC) for 181 stations and the National Interagency Fire Center's Remote Automated Weather Stations (RAWS) for 20 stations. These data were used to develop the daily climate inputs for the LABWM.
Following the methods used in Flint and Martin (2012), the average monthly PRISM data (Daly and others, 1994, 2004) were used as input to the modified inverse-distancesquared interpolation. The monthly PRISM data consist of average monthly precipitation and average monthly maximum and minimum air-temperature maps available for the Nation on an approximate 800-m grid spacing for the 30-year period 1971-2000 (Daly and others, 1994, 2004). The monthly PRISM estimates incorporate multiple variables to account for complex orographic effects on precipitation, such as rain shadows and adiabatic cooling. by using inverse-distancesquared interpolation, the PRISM data were downscaled to the 201-m LABWM grid to define average monthly precipitation and maximum and minimum air-temperature estimates for all grid cells.

In addition to inputs developed for the model cells, PRISM was also used to define average monthly precipitation and average monthly maximum and minimum daily airtemperature estimates for the 201 climate stations (table 2). The average monthly precipitation and average monthly maximum and minimum daily air-temperature estimates were needed for the modified inverse-distance squared interpolation method (Flint and Martin, 2012).The nearest neighbor method was used to define the PRISM average monthly precipitation and maximum and minimum air-temperature estimates for the 201 climate stations. Figure 20 shows the average 1971-2000 January precipitation used to define estimates of January precipitation for the climate stations. Figure 21 shows the average 1971-2000 January minimum air temperature used to define January minimum air temperature for the climate stations.

In general, the LABWM interpolated average annual precipitation was similar to the PRISM estimate, but was not identical because the LABWM honored the daily climate records from the 201 climate stations, and the results were generated over a longer period (100 years) compared to the PRISM results (30 years). As with the distribution of average annual precipitation, the interpolated distribution of average air temperature was similar to the result obtained by using PRISM, but the LABWM results honored the daily airtemperature data from the climate stations.

The LABWM uses the combination of spatially distributed precipitation and average air temperature for each model cell to calculate the location and amount of precipitation falling as snow at each cell. Snowfall of $20.1 \mathrm{~mm} / \mathrm{yr}$ and greater was generally limited to the higher elevations of the San Gabriel Mountains (fig. 22). Snowfall of $321 \mathrm{~mm} / \mathrm{yr}$ and greater was interpolated for the highest elevations of the San Gabriel Mountains, which had a maximum snowfall of $850 \mathrm{~mm} / \mathrm{yr}$. In the Los Angeles recharge-study area (which contributes recharge to the LAGSA), snow did not fall, exception for the rare snowfall (less than $1 \mathrm{~mm} / \mathrm{yr}$ ) along the easternmost boundary. Average snowfall in the LABWM area was $8.3 \mathrm{~mm} / \mathrm{yr}$. 


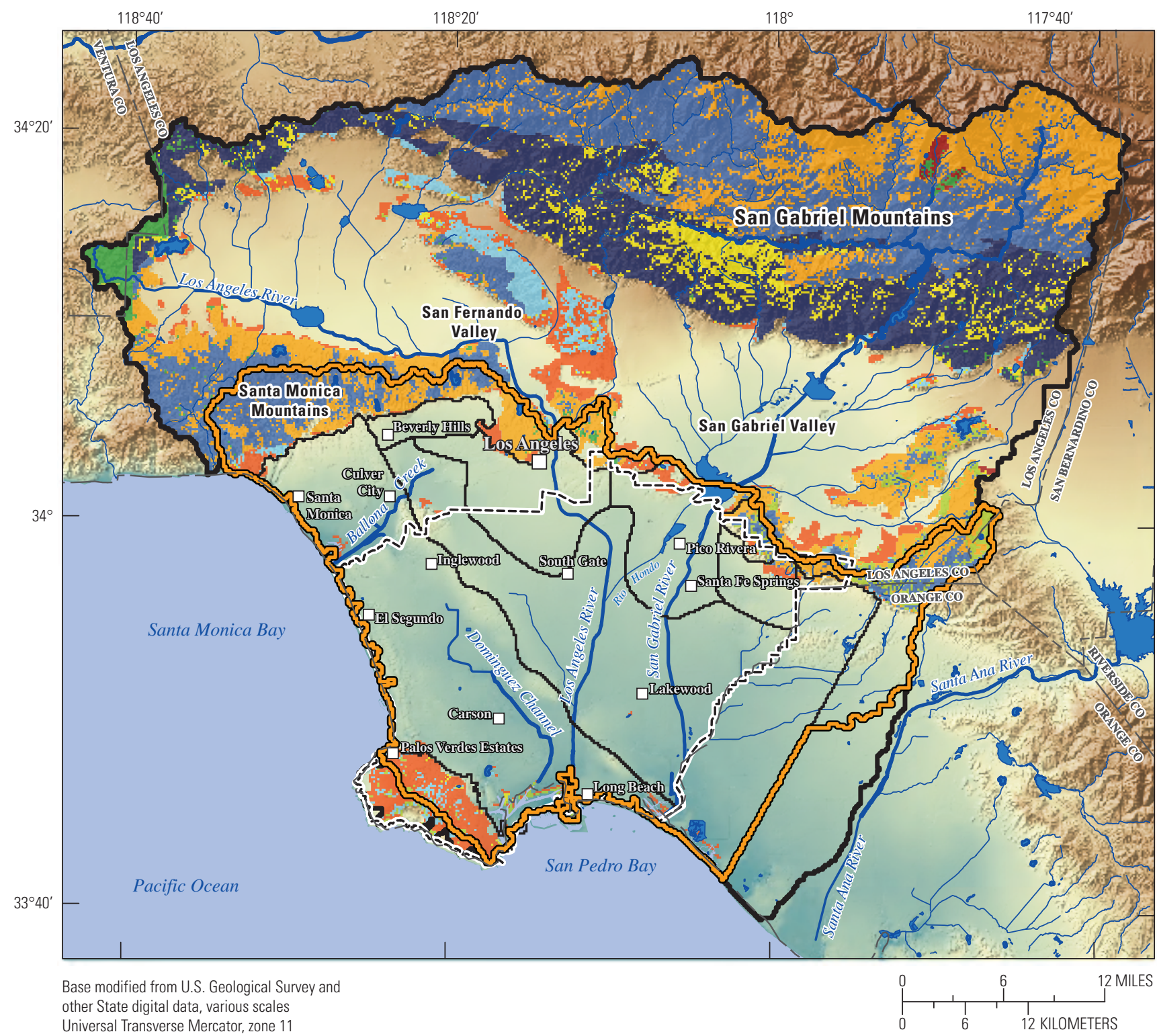

Universal Transverse Mercator zone 11 North American Datum 1983

\section{EXPLANATION}

\begin{tabular}{|c|c|c|c|}
\hline Layer 6 thickness, & eters & & Los Angeles Basin watershed model area boundary \\
\hline $0.1-80.0$ & $241.0-280.0$ & & Water Replenishment District \\
\hline $81.0-120.0$ & $281.0-320.0$ & & Los Angeles recharge study area \\
\hline $1210-160.0$ & $3210-3600$ & & Water bodies and flood-control areas \\
\hline $61.0-200.0$ & $361.0-400.0$ & & Major rivers and streams \\
\hline $201.0-240.0$ & & & $\begin{array}{l}\text { Los Angeles groundwater basins } \\
\text { County line }\end{array}$ \\
\hline
\end{tabular}

Figure 18. Estimated thickness of bedrock-layer 6, Los Angeles Basin watershed model (LABWM), California. 


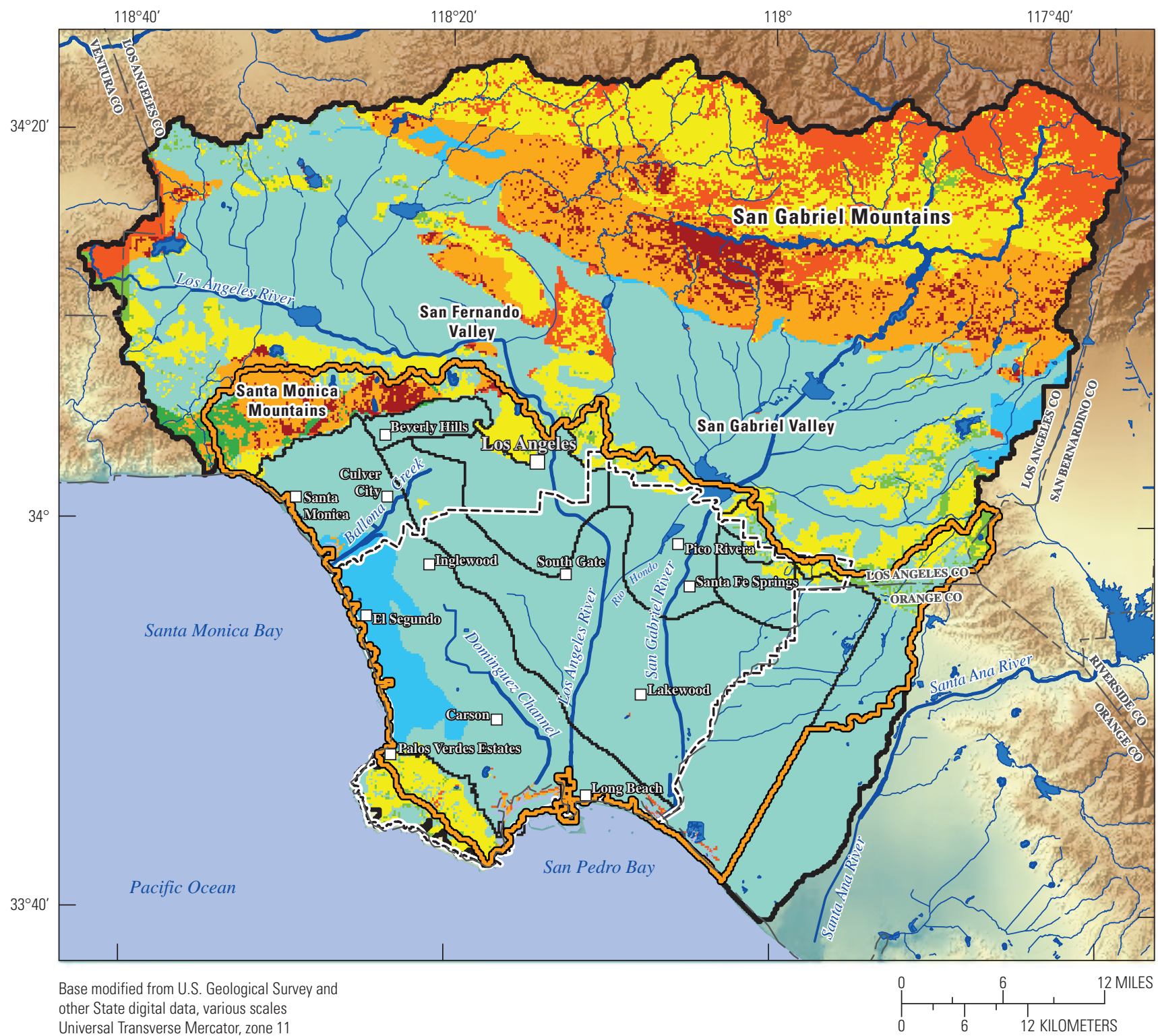

North American Datum 1983

\section{EXPLANATION}

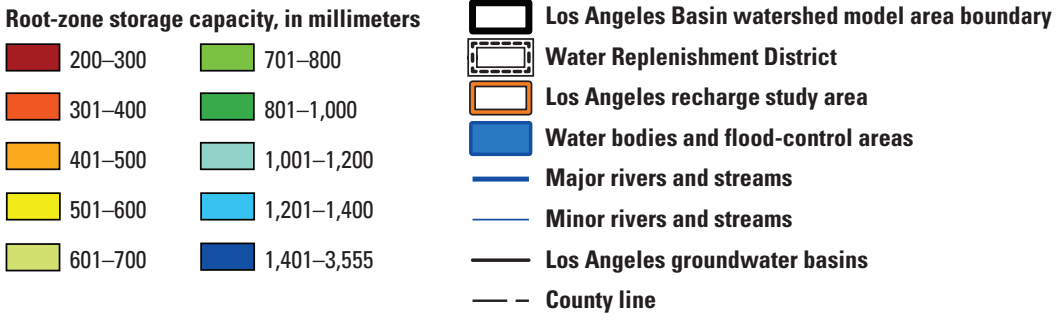

Figure 19. Estimated root-zone storage capacity, Los Angeles Basin watershed model (LABWM), California. 


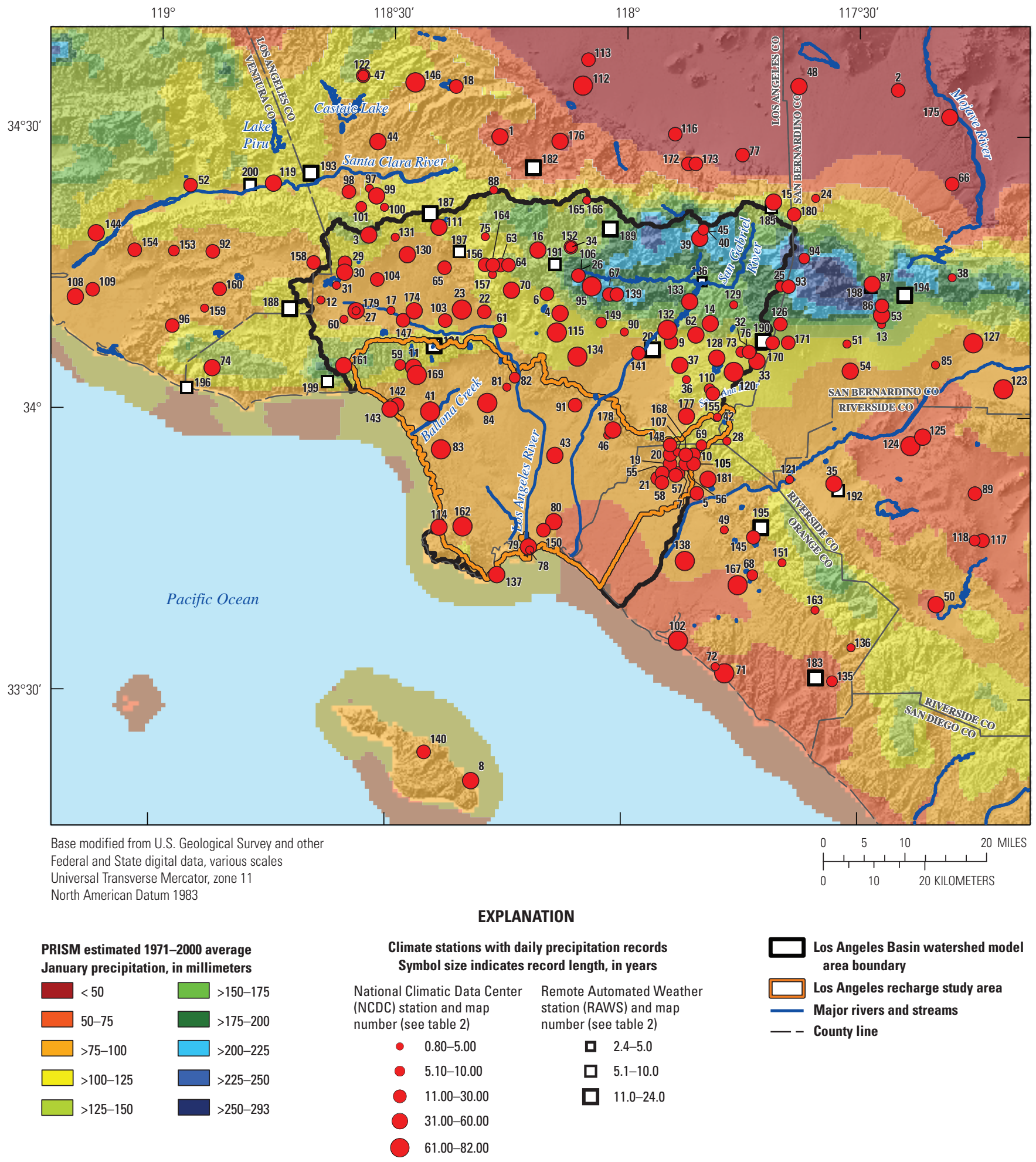

Figure 20. Spatially distributed average January precipitation and climate stations with daily precipitation records used in the Los Angeles Basin watershed model (LABWM), California. 


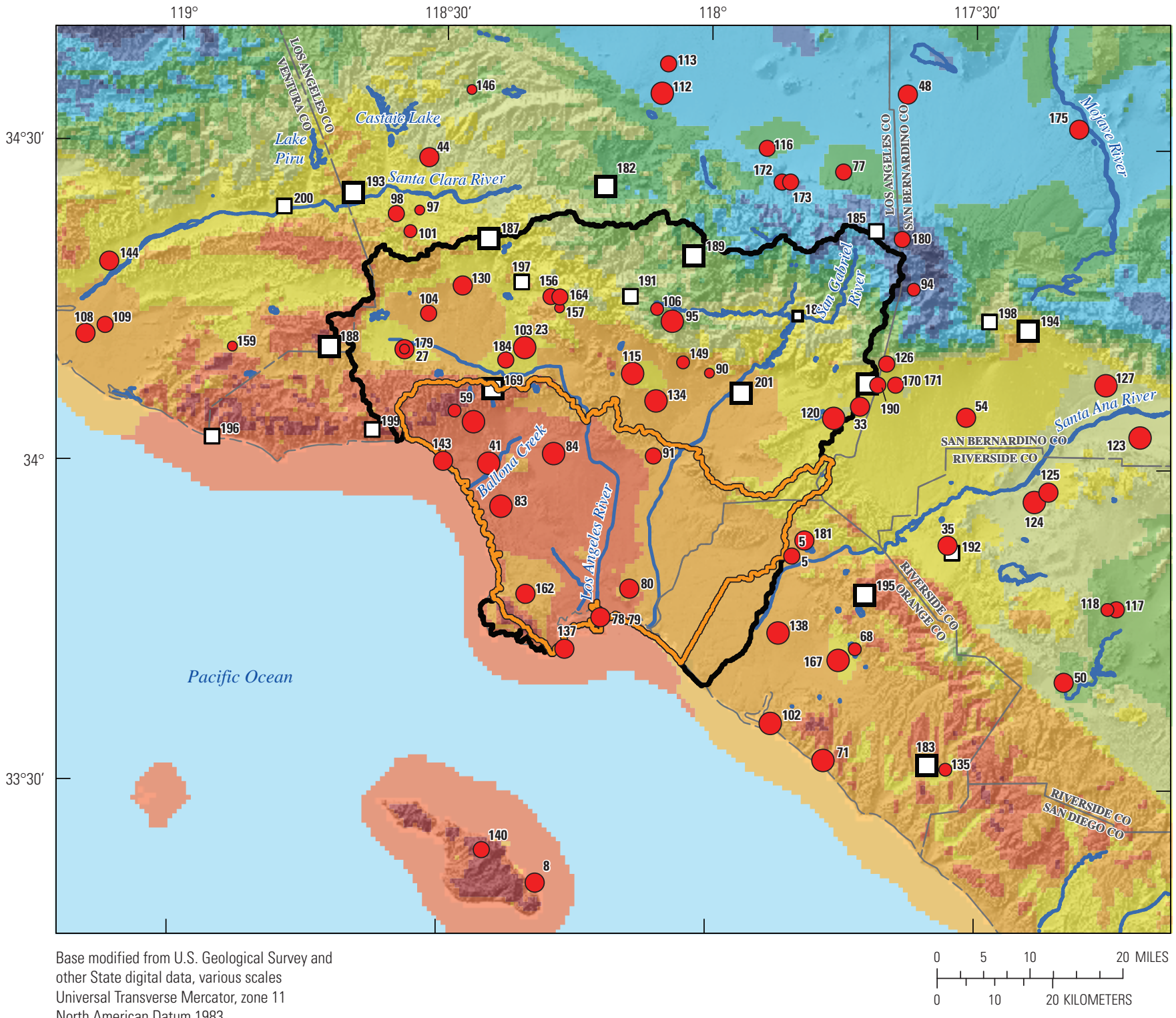

North American Datum 1983

\section{EXPLANATION}

PRISM estimated 1971-2000 average January minimum air temperature, in degrees Celsius

\begin{tabular}{|c|c|}
\hline-11.0 to -3.1 & 3.1 to 4.5 \\
\hline-3.0 to -1.6 & 4.6 to 6.0 \\
\hline-1.5 to 0.0 & 6.1 to 7.5 \\
\hline 0.1 to 1.5 & 7.6 to 9.0 \\
\hline 1.6 to 3.0 & 9.1 to 10.5 \\
\hline
\end{tabular}

Climate stations with daily air temperature records Symbol size indicates record length, in years National Climatic Data Center (NCDC) station and map number (see table 2)

- $1.1-5.0$

- $5.1-10.0$

11.0-30.0

31.0-60.0

61.0-83.0

\section{Remote Automated Weather} station (RAWS) and map number (see table 2)

[ $2.4-5.0$

口 $5.1-10.0$

$11.0-24.0$

Figure 21. Spatially distributed average January minimum daily air temperature and climate stations with daily air-temperature records used in the Los Angeles Basin watershed model (LABWM), California. 


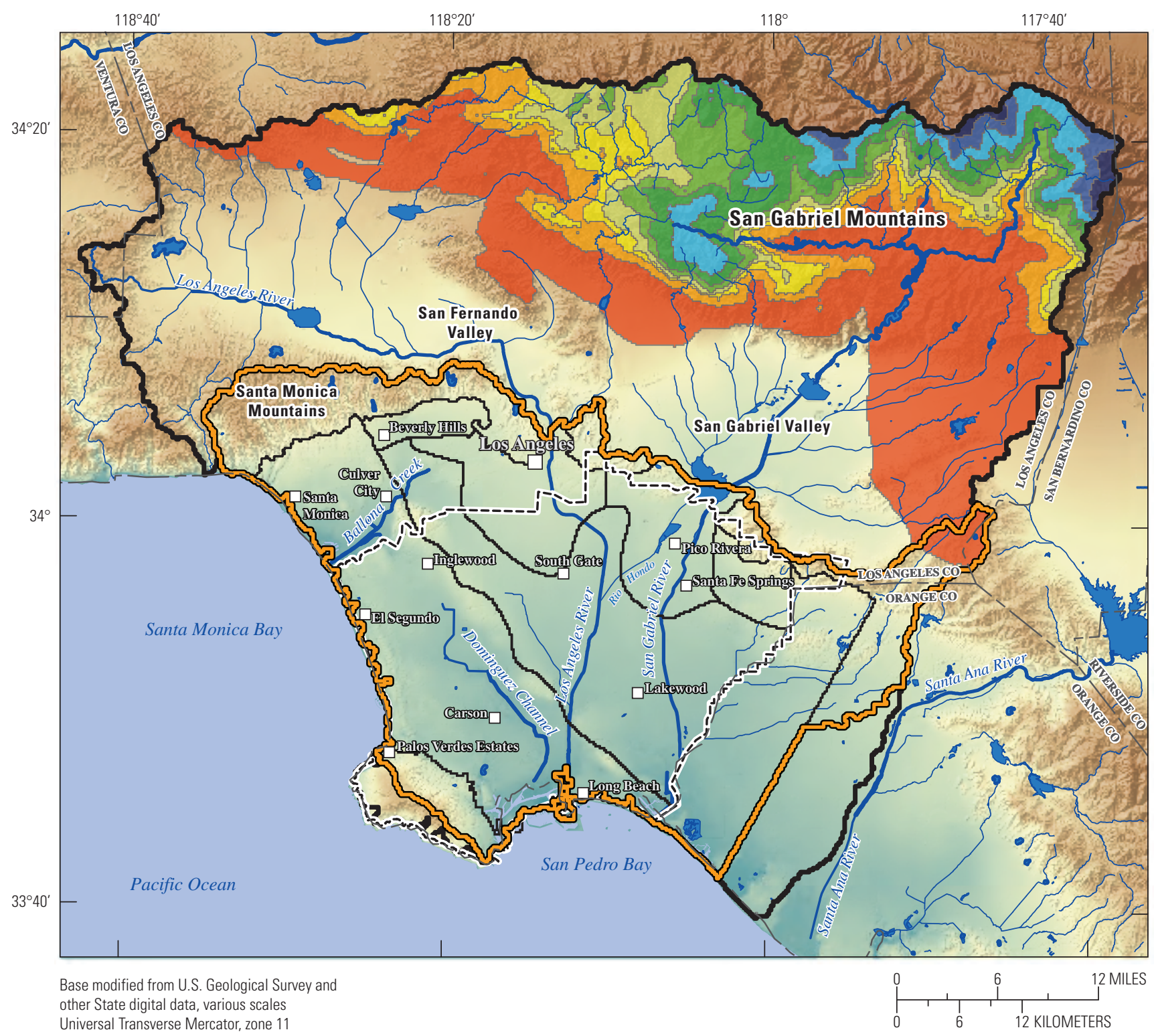

Universal Transverse Mercator, zone 11

North American Datum 1983

\section{EXPLANATION}

Los Angeles Basin watershed model interpolated 1915-2014 snowfall, in millimeters per year

\begin{tabular}{|c|c|}
\hline $0.02-1.00$ & $20.10-40.00$ \\
\hline $1.10-5.00$ & $40.10-80.00$ \\
\hline $5.10-10.00$ & $80.10-160.00$ \\
\hline $10.10-20.00$ & $160.10-320.00$ \\
\hline
\end{tabular}

Los Angeles Basin watershed model area boundary Water Replenishment District

Los Angeles recharge study area

Water bodies and flood-control areas

Major rivers and streams

_ Minor rivers and streams

- Los Angeles groundwater basins

- County line

Figure 22. Average snowfall estimated for water years 1915-2014 by using the Los Angeles Basin watershed model (LABWM), California. 


\section{Atmospheric Parameters}

Monthly atmospheric parameters are used by the LABWM to simulate solar radiation on an hourly basis. The simulated solar radiation is then used to simulate daily PET on the basis of an energy-balance calculation that also incorporates the daily air-temperature inputs. The atmospheric parameters used for the LABWM were based on the values used in the previous INFILv3 applications in the southern California region (Nishikawa and others, 2004; Rewis and others, 2006; Flint and Martin, 2012). The monthly atmospheric parameters are shown in table 8 and included (1) ozone-layer thickness (ozone), (2) precipitable water in the atmosphere (WP), (3) mean atmospheric turbidity (beta), and (4) circumsolar radiation (CSR). Monthly ozone varied from 0.27 to 0.33 , WP varied from 1.0 to 2.44 , beta varied from 0.075 to 0.09 , and CSR varies from 0.57 to 0.9 (table 8).

\section{Model Coefficients}

Model coefficients are used in the INFILv3 code for empirical functions and controls that are applied on a basinwide scale (rather than on a grid-cell basis). The empirical functions include (1) storm durations for winter and summer storms, (2) sublimation and snowmelt, and (3) effective hydraulic conductivities for stream channels (Hevesi and others, 2003; U.S. Geological Survey, 2008). For the LABWM area, the duration of winter storms (September 1 to May 31) was estimated to be 12 hours, and the duration of summer storms (June 1 to August 31) was estimated to be 2 hours. These estimated storm durations were used in previous INFILv3 applications for nearby study areas: the San Gorgonio Pass area east of the LABWM area (Rewis and others, 2006),the Big Bear Valley study area (Flint and Martin, 2012), and the San Gorgonio Pass region (Hevesi and Christensen, 2015).

Values for model coefficients used for simulating snowmelt and sublimation were also the same as those used in previous INFILv3 applications in the southern California region (Hevesi and others, 2003; Nishikawa and others, 2004; Rewis and others, 2006; Flint and Martin, 2012; Hevesi and Christensen, 2015). Precipitation was assumed to be in the form of snow when the average daily air temperature was equal to or less than $32^{\circ} \mathrm{F}$. Daily snowfall was added to the snowpack-storage term in the daily water balance. When the average daily air temperature was less than or equal to freezing, snowmelt was assumed to be zero, but the snowpackstorage term was still reduced a fraction by using an assumed sublimation model that calculated sublimation as a percentage of PET and the available water in the snowpack. When the daily maximum air temperature was greater than freezing, an empirical temperature-index model was applied by using parameters calibrated for the Sierra Nevada (Maidment, 1993) to calculate the daily snowmelt, and the snowpack was reduced by this amount.
Model coefficients used for simulating the effective hydraulic conductivities for stream channels were dependent on the number of upstream cells and were adjusted during the model-calibration process. Model coefficients used to represent stream-channel characteristics included (1) the minimum number of upstream cells used to define the main stream channels and (2) the saturated hydraulic-conductivity multiplier for soils in the main stream channels. For the LABWM, the minimum number of upstream cells was set to 100 , and the saturated hydraulic-conductivity multiplier was set 10 . This configuration assumed coarser soils in larger channels and a tenfold increase in the saturated hydraulic conductivity of the channel bed relative to the surrounding inter-channel areas.

\section{Boundary Conditions}

Boundary conditions for the LABWM included the simulated daily surface-water discharge from model subdomains that were tributaries to downstream subdomains (fig. 9). To establish the boundary conditions, the upstream model subdomains were simulated first. The simulated surface-water discharges from an upstream model subdomain were input to the downstream model subdomain as daily inflows to the grid cell directly downstream from the outflow cell in the upstream subdomain. In the LABWM layout, the Rio Hondo (RIOH) and upper Los Angeles River (ULAR) subdomains were upstream from the lower Los Angeles River (LARV) subdomain, and the upper San Gabriel River (USGR) subdomain was upstream from the lower San Gabriel River (SGRV) subdomain. To define the surface-water inflow boundary conditions for the lower Los Angeles River (LARV) and SGRV subdomains, the Rio Hondo (RIOH), upper Los Angeles River (ULAR), and upper San Gabriel River (USGR) subdomains were simulated first.

Boundary conditions also included estimates of average quarterly urban irrigation for the general area of the Los Angeles recharge-study area. The average quarterly rates were applied uniformly to each quarterly period in the simulation period. The quarterly urban-irrigation estimates were specified for all irrigated cells as a constant daily inflow boundary condition for each quarter. Annual irrigation was calculated from the quarterly urban irrigation estimates. The annual irrigation result indicated the spatial distribution of the quarterly irrigation estimates included in the model (fig. 23). Although the amount of urban irrigation was different for each quarter, the spatial distribution of urban irrigation was constant. The high annual irrigation rates of 321 to $412 \mathrm{~mm} / \mathrm{yr}$ were estimated for residential areas that had a relatively large percentage of pervious area. Annual irrigation rates of 241 to $280 \mathrm{~mm} / \mathrm{yr}$ were more widespread and were estimated for the higher density residential areas that had a smaller percentage of pervious area. Relatively low irrigation rates of 40 to $160 \mathrm{~mm} / \mathrm{yr}$ were estimated for the more densely developed commercialized zones and transportation corridors. 
Table 8. Atmospheric parameters, Los Angeles basin watershed model, California.

[Beta, average monthly mean atmospheric turbidity; cm, centimeter; CSR, average monthly circumsolar radiation; Ozone, average monthly ozone layer thickness; WP, average monthly precipitable water in the atmosphere]

\begin{tabular}{lcccc}
\hline \multirow{2}{*}{ Month } & \multicolumn{4}{c}{ Monthly atmospheric parameter values } \\
\cline { 2 - 5 } & $\begin{array}{c}\text { Ozone } \\
\text { (cm) }\end{array}$ & $\begin{array}{c}\text { WP } \\
\text { (cm) }\end{array}$ & $\begin{array}{c}\text { Beta } \\
\text { (unitless) }\end{array}$ & $\begin{array}{c}\text { CSR } \\
\text { (unitless) }\end{array}$ \\
\hline January & 0.29 & 1.00 & 0.075 & 0.85 \\
February & 0.31 & 1.00 & 0.075 & 0.85 \\
March & 0.32 & 1.05 & 0.075 & 0.85 \\
April & 0.33 & 1.10 & 0.085 & 0.85 \\
May & 0.33 & 1.50 & 0.085 & 0.74 \\
June & 0.32 & 1.80 & 0.090 & 0.74 \\
July & 0.30 & 2.20 & 0.090 & 0.57 \\
August & 0.29 & 2.44 & 0.084 & 0.57 \\
September & 0.28 & 2.00 & 0.077 & 0.66 \\
October & 0.27 & 1.40 & 0.075 & 0.74 \\
November & 0.27 & 1.05 & 0.075 & 0.90 \\
December & 0.28 & 0.95 & 0.075 & 0.90 \\
\hline
\end{tabular}

${ }^{1}$ Parameter values from U.S. Geological Survey, 2008.

The lowest irrigation rates, less than $40 \mathrm{~mm}$, were estimated for the high-density developed zones, such as major highways and city centers. Irrigation rates of zero were estimated for industrialized areas.

Average quarterly (January-March, April-June, July-September, October-December) urban irrigation, calculated as the basin-wide average irrigation depth for the 11 subdomains with urban irrigation, indicated variability in the estimated irrigation among quarters and subdomains (fig. 24). The Topanga Creek (TOPC) subdomain did not have any cells with urban irrigation and, therefore, was omitted. The January-March quarter had the smallest estimated irrigation amounts, with basin-wide average irrigation of 5-10 mm for 9 of the 11 subdomains. The July-September quarter had the largest estimated irrigation amounts, with average basin-wide irrigation of 53-64 $\mathrm{mm}$ for seven of the subdomains. For all quarters, the lower Santa Monica Basin (LSMB) subdomain had the most irrigation, and the Seal Beach (SEAL) subdomain had the second most irrigation. The upper Los Angeles River (ULAR) subdomain had the smallest irrigation amount because only a small part of the subdomain was included in the area where urban-irrigation estimates were defined.

\section{Initial Conditions}

Initial conditions required by LABWM include the water contents of all root-zone layers, the perched zone (layer 7), and the snowpack. As in previous INFILv3 applications
(Nishikawa and others, 2004; Rewis and others, 2006; Flint and Martin, 2012; Hevesi and Christensen, 2015), all simulations in this study were run by using an initial water content for root-zone layers 1-5 (soil layers) that was calculated as 1.5 times the wilting-point water content (table 6). An initial water content of zero was assigned to rootzone layer 6, the perched zone (layer 7), and the snowpack. An initialization period of 9.75 years (from January 1, 1905, to September 30, 1914) was used for all simulations in order to mitigate the effect of initial conditions on the 100-year targetsimulation period (water years 1915-2014).

\section{Model Calibration}

Model calibration is the process of making adjustments, within justifiable ranges, to initial estimates of selected model parameters to obtain reasonable agreement between simulated and measured observations. Precipitation-runoff models, such as PRMS (Markstrom and others, 2008; Jeton and Maurer, 2011) and INFILv3 (Hevesi and others, 2003; Rewis and others, 2006) typically are calibrated by comparing simulated streamflow to available records of measured streamflow, preferably by using continuous records that span multi-year periods. In this study, calibration of the LABWM consisted of comparing simulated daily, monthly, and annual streamflow with measured streamflow at six gages in the LABWM area.

\section{Streamflow Observations}

The streamflow records used for calibration included observations at four USGS streamflow gaging stations (http://waterdata.usgs.gov/ca/nwis) and two streamflow gaging stations maintained by the Los Angeles County Department of Public Works (Los Angeles County Department of Public Works, 2006; http://dpw.lacounty.gov/wrd/Runoff/index.cfm; fig. 25; table 9). Three gages, BALC6, COMP4, and COYC1, have drainage areas in the Los Angeles recharge-study area (area defined as contributing recharge to the LAGSA), and three gages, TOPG1, ALHW6, and SJCE1, have drainage areas outside of, but next to the Los Angeles recharge-study area (area contributing recharge to the LAGSA) boundary (fig. 25). The four USGS gages had daily mean discharge records. The LACDPW gages had a combination of daily, monthly, and annual (water year) records. In general, the USGS records were older, with the most recent data for water year 1979, whereas the LACDPW records were more recent. The LACDPW gages were still active at the time of this study. The record lengths ranged from a minimum of 14 years for gage SJCE1 to a maximum of 62 years for gage ALHW6.

The drainage areas for the six gages vary from a minimum of $47 \mathrm{~km}^{2}$ for TOPG1 to a maximum of $388 \mathrm{~km}^{2}$ for COYC1. Only one gage, COMP4, has a drainage area completely within the LAGSA. Two gages, BALC6 and COYC1, have drainage areas mostly within the LAGSA. 


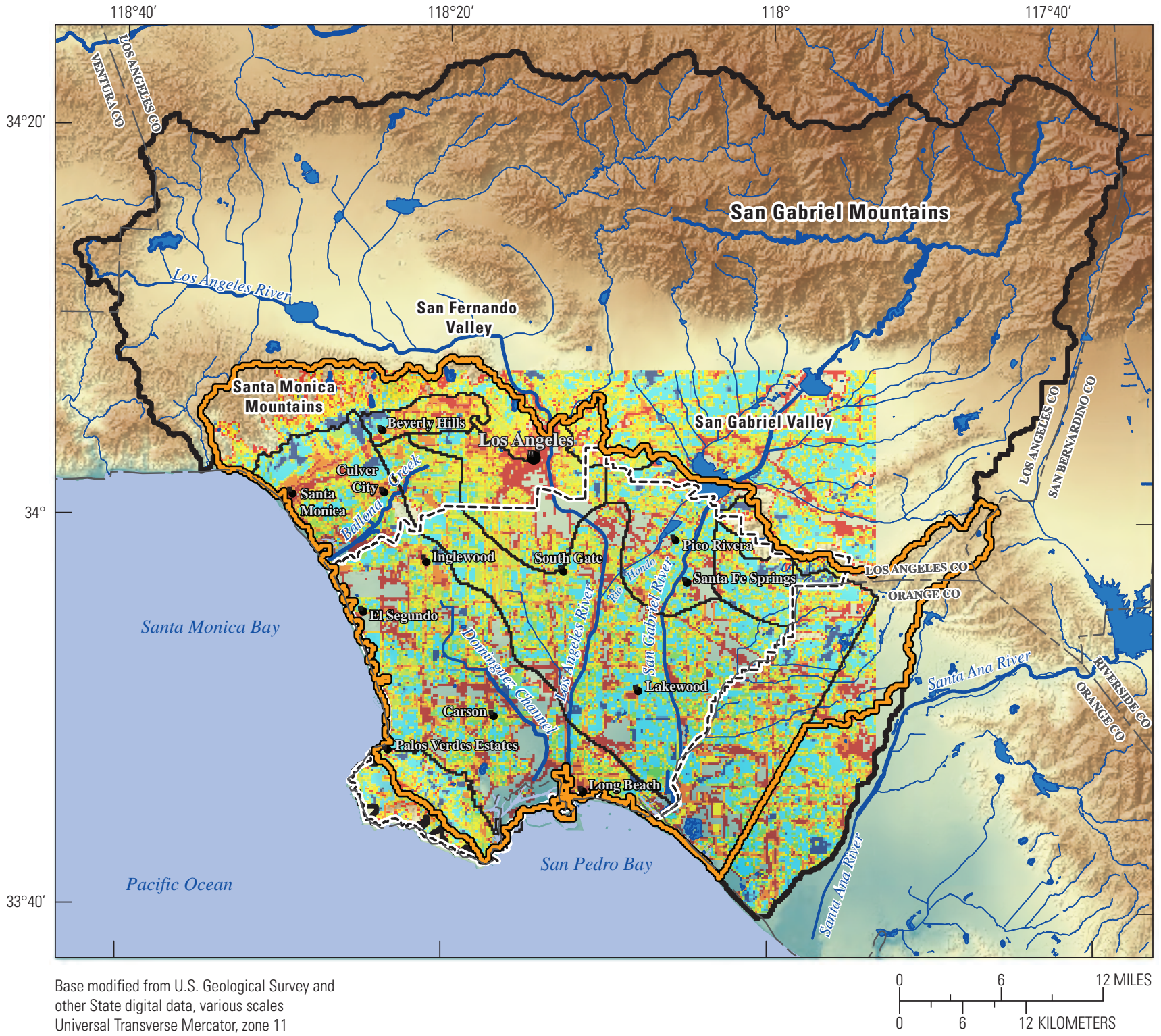

Universal Transverse $M$ North American Datum 1983

\section{EXPLANATION}

Los Angeles Basin watershed model estimated 1915-2014 urban irrigation, in millimeters per year

\begin{tabular}{|c|c|}
\hline $0.1-40$ & $161-200$ \\
\hline $41-80$ & $201-240$ \\
\hline $81-120$ & $241-280$ \\
\hline $121-160$ & $281-3$ \\
\hline
\end{tabular}

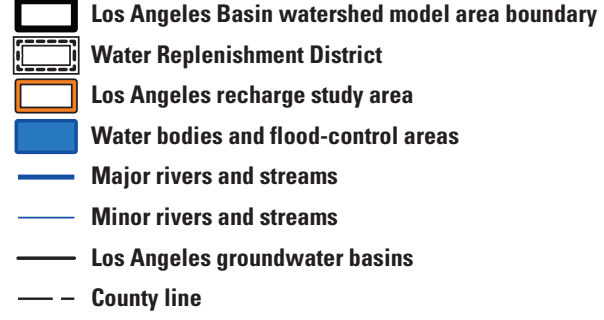

Figure 23. Average annual estimated urban irrigation, Los Angeles Basin watershed model (LABWM), California. 


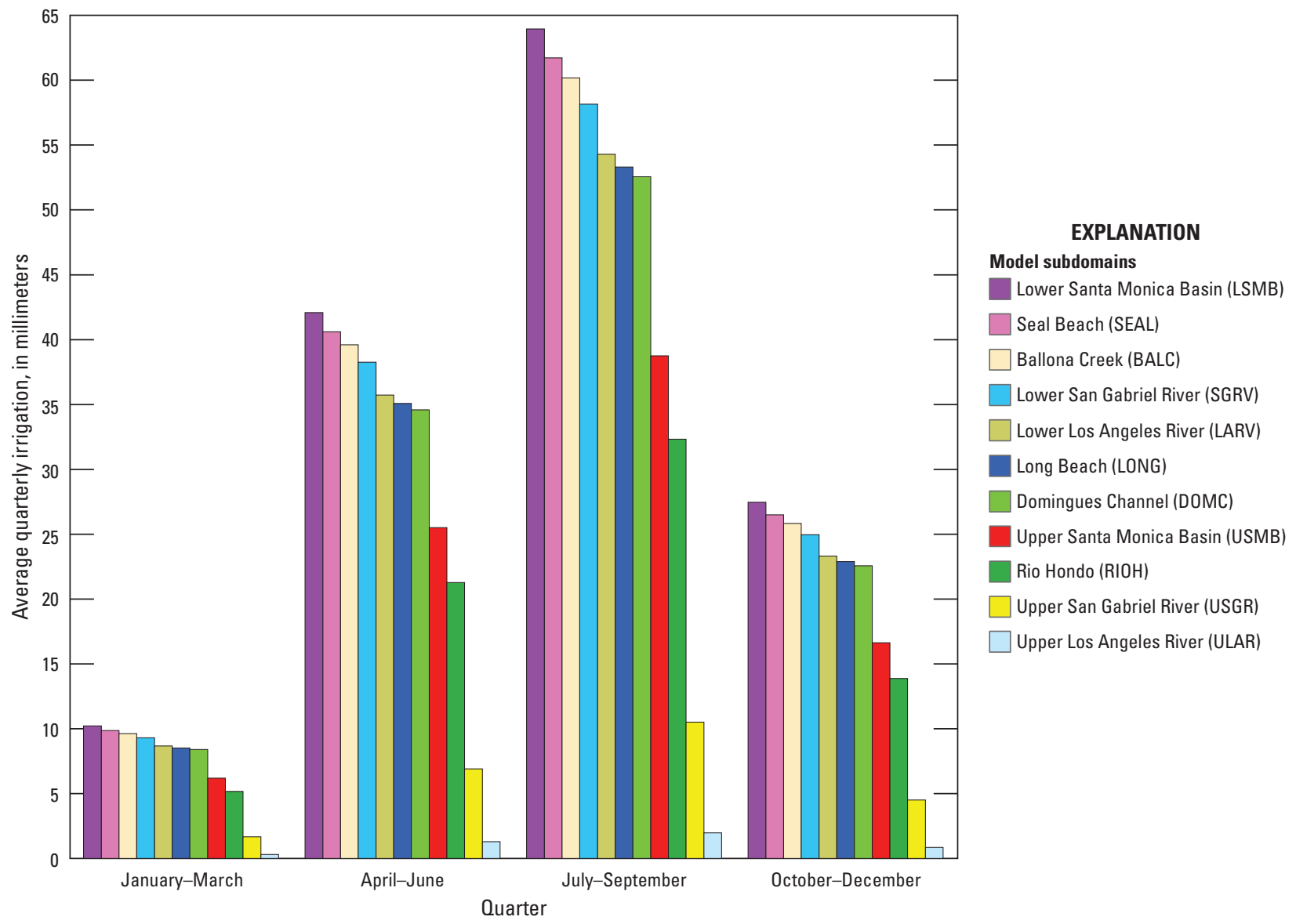

Figure 24. Average quarterly irrigation for 11 subdomains, Los Angeles Basin watershed model (LABWM), California. 


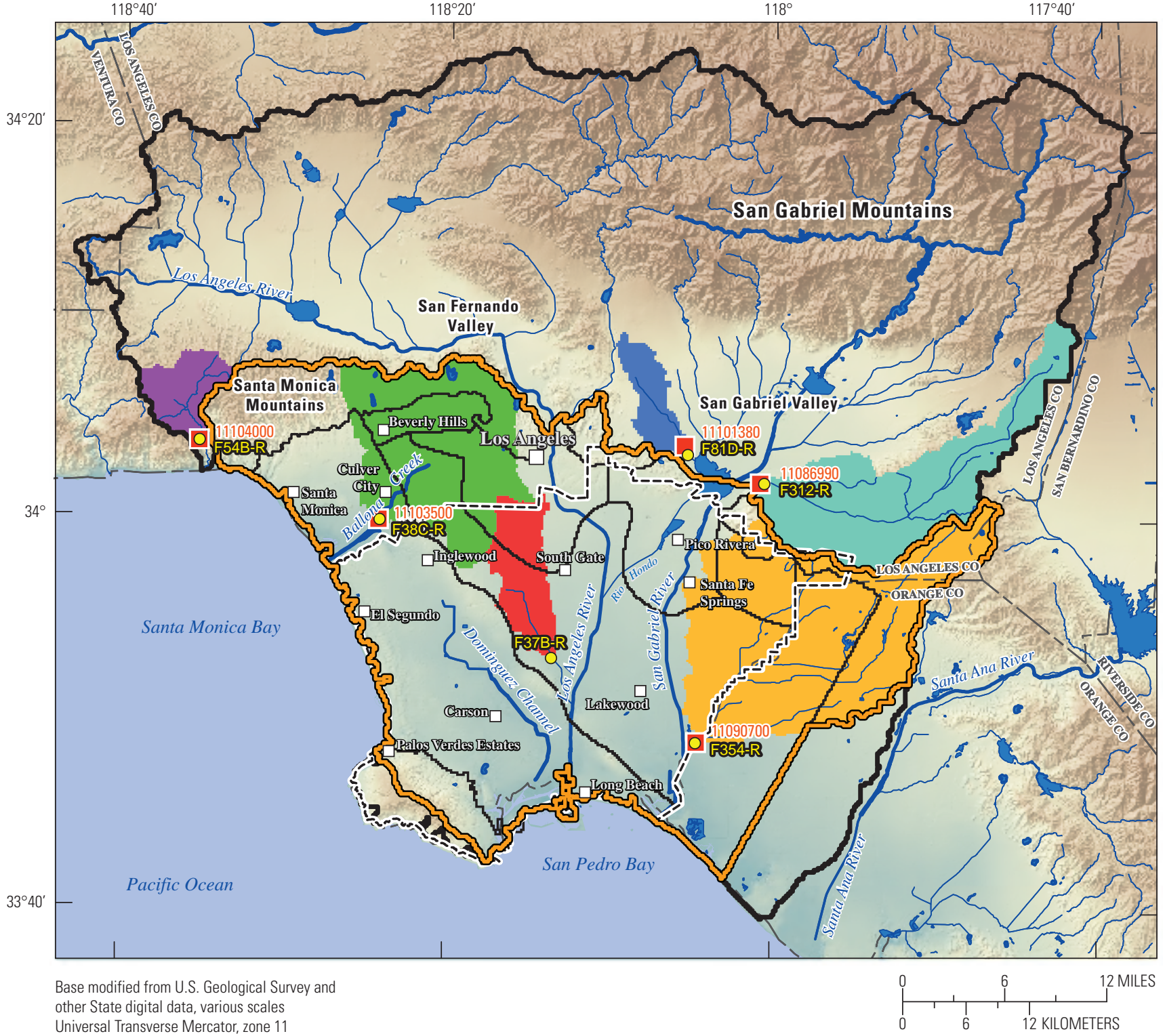

Universal Transverse Mercator, zone 11

North American Datum 1983

EXPLANATION
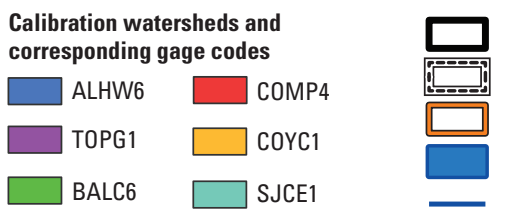

Los Angeles Basin watershed model area boundary

Water Replenishment District

Los Angeles recharge study area

Water bodies and flood-control areas

Major rivers and streams

Minor rivers and streams

Los Angeles groundwater basins

- County line

OF354:R LACDPW gages

11090700 USGS gages

Figure 25. Six streamflow-gaging stations used for model calibration, Los Angeles Basin watershed model (LABWM), California. 


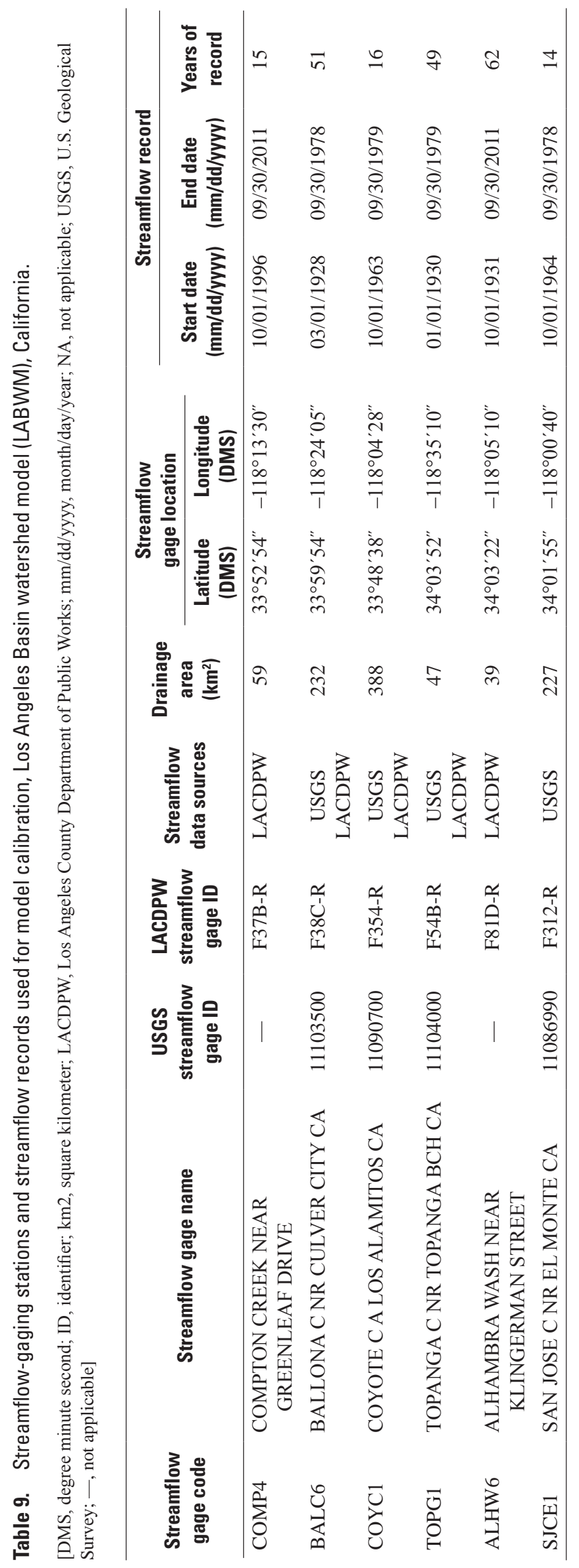


Streamflow records for gages COMP4, TOPG1, and ALHW6 were generally not affected by flow diversions. Records from three gages (SJCE1, BALC6, and COYC1) were partially affected by flow regulations from reservoirs, detention basins, debris basins, or spreading grounds upstream from the gages. Although the regulated flows increased uncertainty in model calibration, including these records was preferable to not including the records because of the general sparsity of streamflow records for the study area.

\section{Calibration Procedure}

Calibration of the model was done by using a trial and error approach where selected model parameters were adjusted until a satisfactory fit was obtained between simulated and measured streamflow values. Parameters adjusted during the calibration process were based on findings from previous applications of the INFILv3 code (Hevesi and others, 2003; Rewis and others, 2006; Flint and Martin, 2012; Hevesi and Christensen, 2015). The parameters included root-zone layer thicknesses, root-density coefficients, soil hydraulic conductivity, upper and lower hydraulic conductivity for layer 6 , the effective porosity of layer 6 , the lateral seepage hydraulic conductivity for layer 7 , and coefficients defining stream channel characteristics.

A qualitative and quantitative analysis of the goodnessof-fit between the simulated and measured streamflow discharge was done by using daily mean discharge, monthly mean discharge, and annual (water year) mean discharge. Daily streamflow was used to analyze the match of simulated streamflow to peak flows and the timing of runoff in response to storms. Monthly streamflow was used to analyze model fit in terms of matching seasonal variations in streamflow. Annual streamflow was used to evaluate model fit in terms of overall bias and the match to variations in streamflow for wet and dry periods.

The qualitative analysis consisted of visual comparisons of the closeness-of-fit between measured and simulated streamflow hydrographs. A qualitative analysis of monthly and annual streamflow was also done by using a visual comparison of the closeness-of-fit between the plotted values of measured and simulated streamflow (for monthly and annual flows) and the one-to-one line for measured streamflow.

The quantitative analysis was based on two goodnessof-fit statistics: (1) the percent average estimation error (PAEE; Rewis and others, 2006; Woolfenden and Nishikawa, 2014) and (2) the Nash-Sutcliffe model efficiency (NSME; Nash and Sutcliffe, 1970; Markstrom and others, 2008). The PAEE provides a measure of model bias and was calculated as described in Woolfenden and Nishikawa (2014). For this study, absolute PAEE values of 20 to 10.1 percent were considered satisfactory, absolute values of 10 to 5.1 percent were considered good, and values between plus 5 and minus 5 percent were considered very good. In general, values of 20 and less indicated an acceptable or favorable model calibration, whereas values greater than 20 indicated a poor calibration.
The NSME provides a standardized measure of the overall goodness-of-fit in terms of the mean-squared estimation error (Markstrom and others, 2008) and was calculated following Nash and Sutcliffe (1970). Values of NSME greater than 0 indicate a model fit better than the sample mean, and values close to 1.0 indicate a good match between simulated and measured streamflow (Nash and Sutcliffe, 1970; Markstrom and others, 2008). For this study, NSME values of 0.6 to 0.69 were considered satisfactory, values of 0.7 to 0.79 were considered good, values of 0.8 to 0.89 were considered very good, and values of 0.9 or greater were considered excellent in terms of indicating model performance. In general, values of 0.6 and greater indicated an acceptable or favorable model calibration, whereas values less than 0.6 indicated a poor calibration.

\section{Calibration Results}

\section{Compton Creek (gage COMP4)}

Comparison of hydrographs for gage COMP4 on Compton Creek indicated a good to very good match between simulated and measured daily and monthly streamflow; however, a poor fit was indicated between simulated and measured annual streamflow by the NSME statistic (fig. 26; table 10). The model indicated a tendency to overestimate flows at gage COMP4, resulting in a PAEE of 18 for daily and monthly flows and 23 for the longer, annual hydrograph. For the shorter period covered by the daily and monthly records, a generally favorable match was indicated between simulated and measured peak flows. The annual records cover a longer period (water years 1939-2011), however, and the annual hydrograph comparison indicated a tendency of the model to overestimate total streamflow for the water years when there was higher total streamflow, particularly during the early part of the record (fig. 26C).

\section{Ballona Creek (gage BALC6)}

\section{Comparison of hydrographs for gage BALC6 on}

Ballona Creek indicated a generally favorable match between simulated and measured streamflow for water years 1932-78 (fig. 27; table 10). The results for Ballona Creek indicated an overall better calibration compared to gage COMP4, because estimation bias was much closer to zero; a PAEE value of -6 indicated a good calibration for daily, monthly, and annual flows. In addition, the NSME results were better for monthly and annual flows compared to results for gage COMP4; an excellent result of 0.93 was obtained for monthly flows, and a very good result of 0.82 was obtained for annual flows. A good general match to the peak monthly and annual flow was a primary reason for the greater NSME values. Although the peak daily flows were not as well matched by the model, the intermediate-to-low daily flows were well matched, and the NSME of 0.74 indicated a good calibration result. 
A

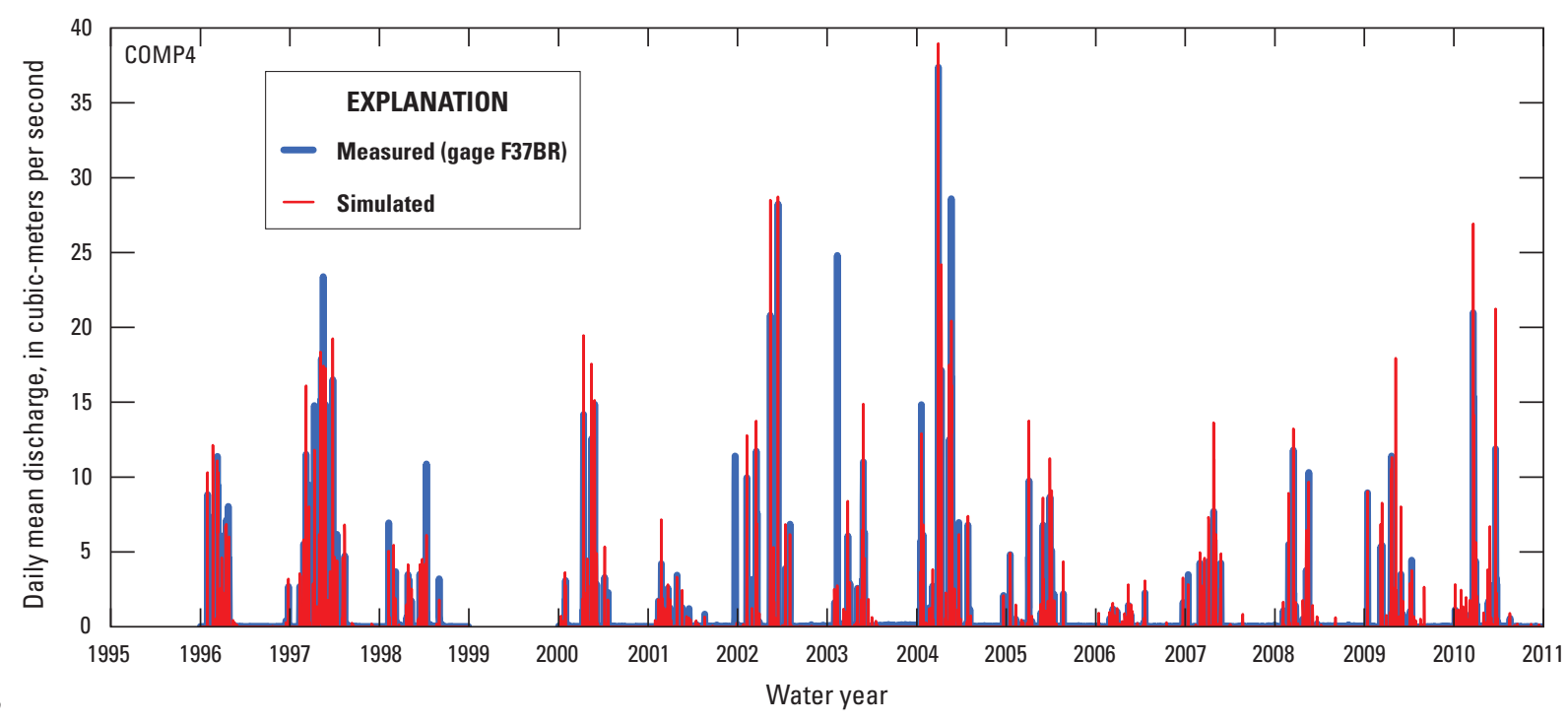

B

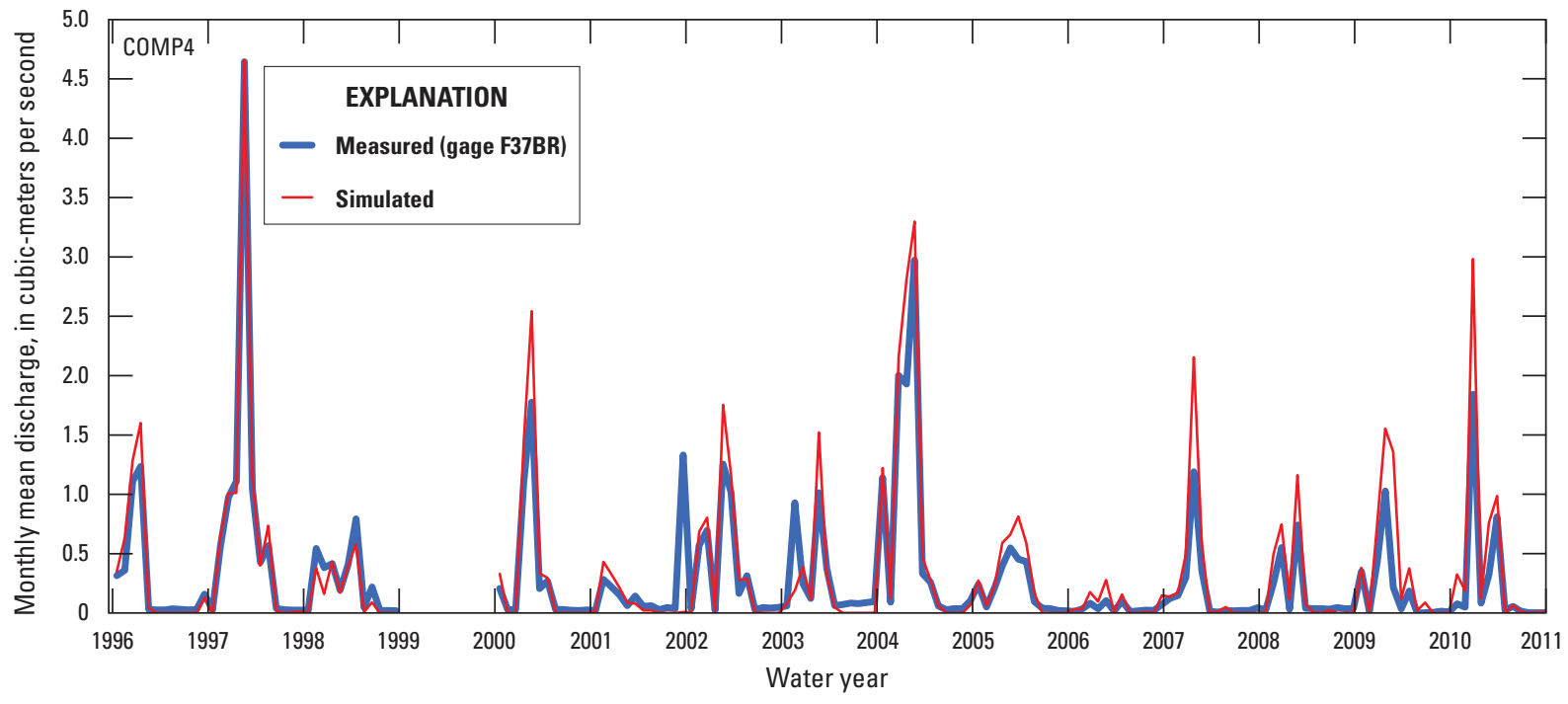

C

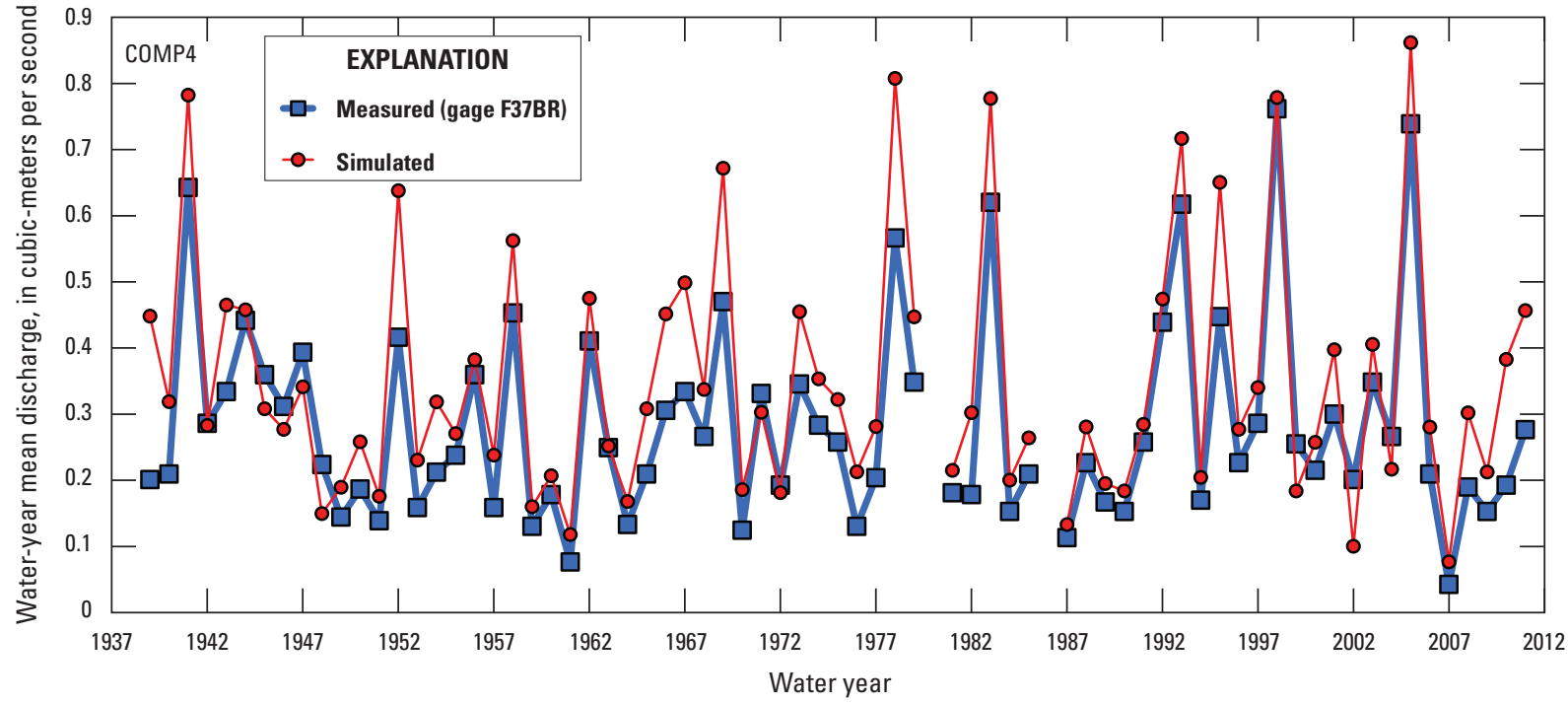

Figure 26. Comparison of simulated and measured streamflow at gage COMP4, Los Angeles Basin watershed model (LABWM), California: $A$, daily; $B$, monthly; $C$, annually. 


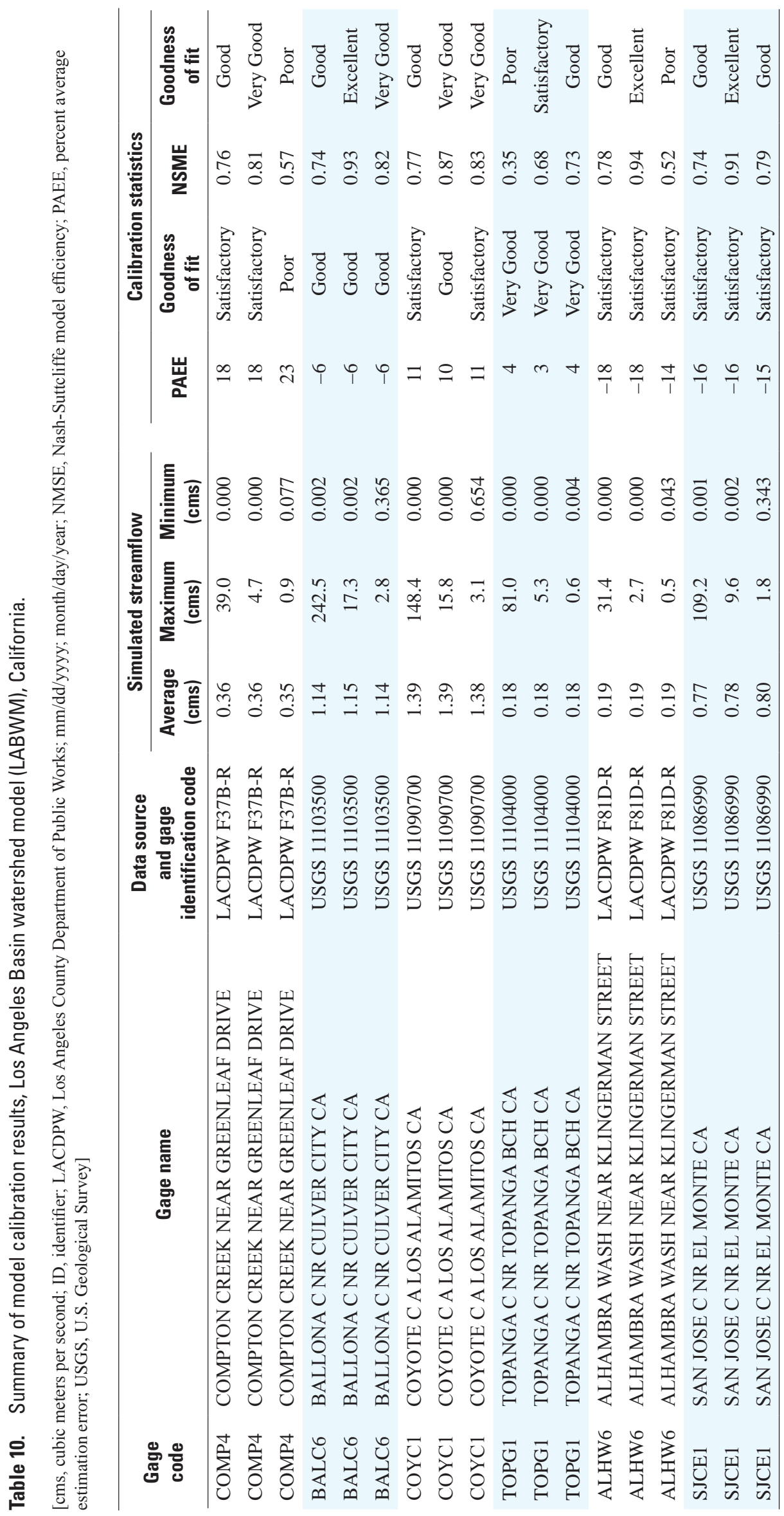




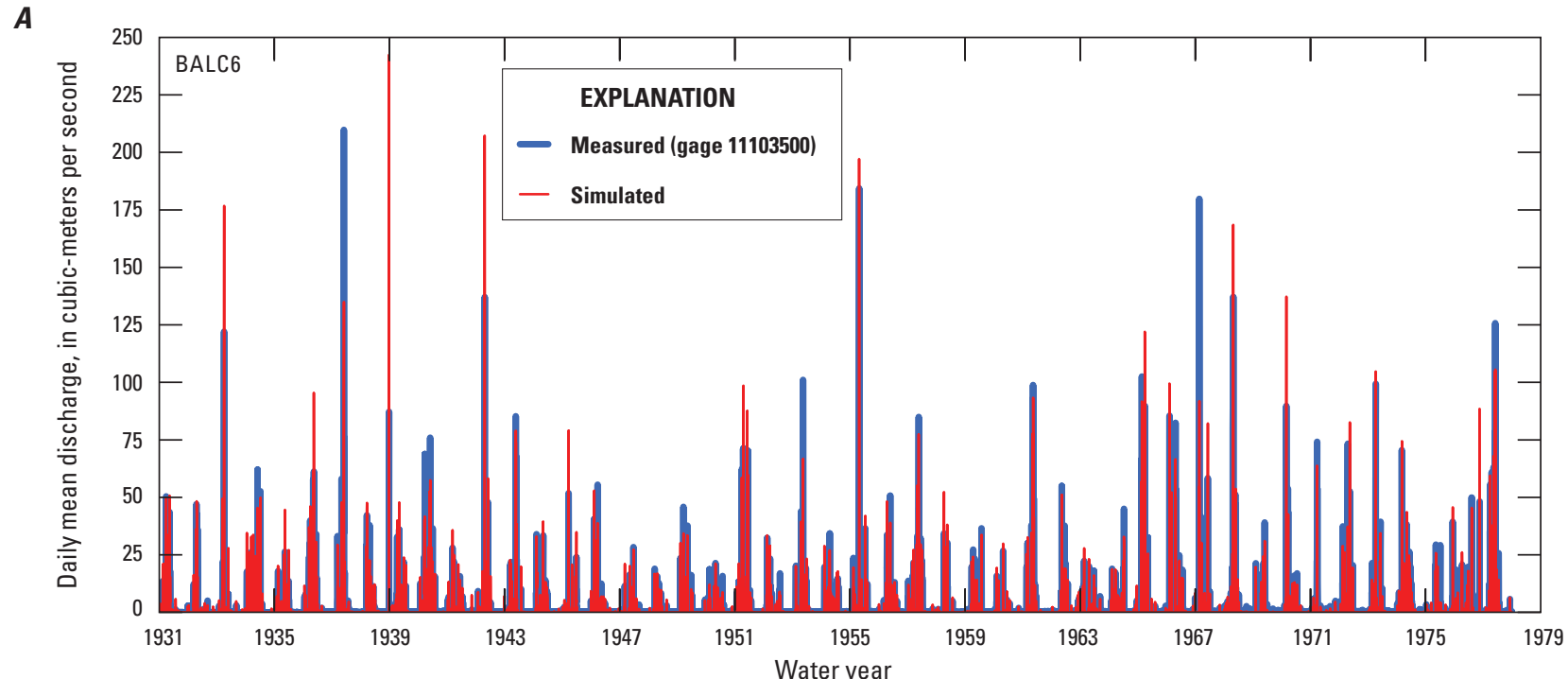

B

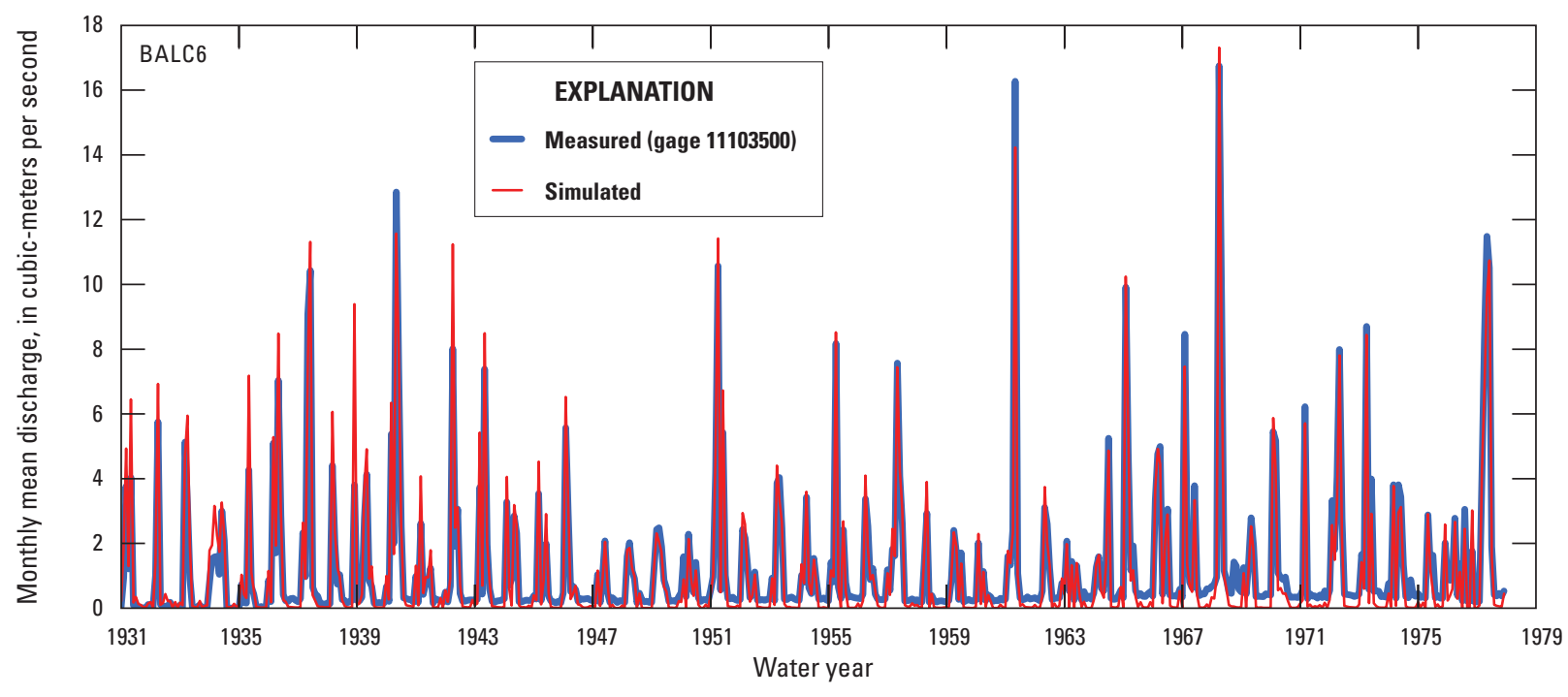

C

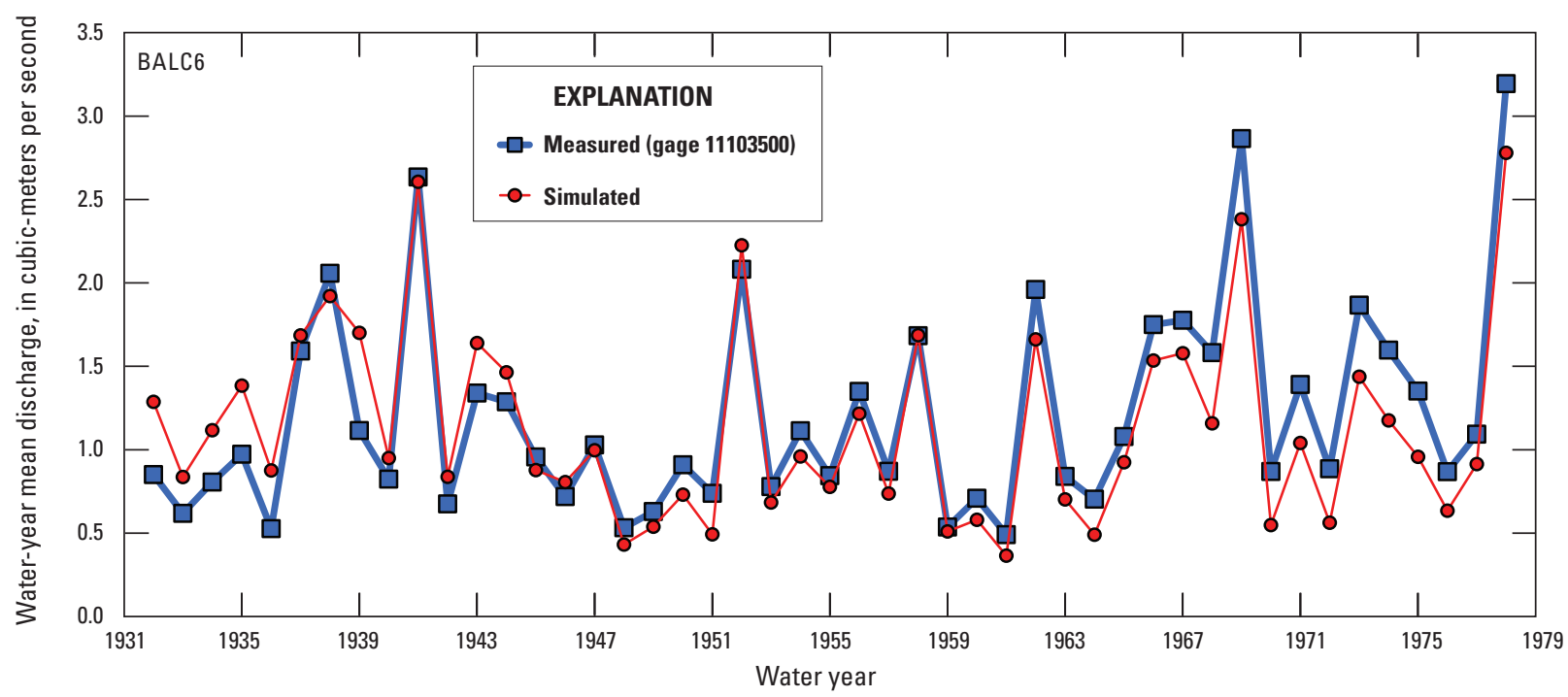

Figure 27. Comparison of simulated and measured streamflow at gage BALC6, Los Angeles Basin watershed model (LABWM), California: $A$, daily; $B$, monthly; $C$, annually. 


\section{Coyote Creek (gage COYC1)}

Calibration results for gage COYC1 on Coyote Creek were considered good for daily streamflow and very good for monthly and annual streamflow in terms of the NSME statistic (fig. 28; table 10). The PAEE result indicated a tendency of the model to overestimate streamflow at this gage, but only by about 10 to 11 percent, which was considered a good to satisfactory calibration for this study. The daily, monthly, and annual hydrographs all indicated a shift in estimation bias through time from water year 1964 to water year 1979. Prior to about water year 1971, the model showed a tendency to overestimate the peak daily flows, the peak monthly flows, and the annual flows. After water year 1977, the model showed a tendency to underestimate the peak daily flows, the peak monthly flows, and the annual flows. For the central part of the simulation period, a better overall fit between simulation and measured flow was indicated.

\section{Toponga Creek (gage TOPG1)}

Results for NSME for gage TOPG1 on Toponga Creek ranged from poor for daily streamflow to satisfactory for monthly streamflow and good for annual streamflow (fig. 29; table 10). Although the PAEE result is less than 5 , and therefore indicated a very good calibration in terms of minimized estimation bias, the model also indicated a tendency to overestimate many of the lower flows and underestimate many of the higher flows, causing a deterioration in the NSME statistic. This was especially true for daily streamflow, and the over- and underestimation of peak flows resulted in a poor NSME of 0.35. The peak monthly and annual flows were better matched by the model, improving the NSME to 0.68 for monthly streamflow and to 0.73 for annual streamflow. Unlike results for gages BALC6 and COYC1, the hydrographs for gage TOPG1 did not indicate a shift in the fit between simulated and measured streamflow through time. It is possible that the changes in watershed characteristics from increased urbanization that could be affecting the watersheds for gages BALC6 and COYC1 were not affecting the gage TOPG1 watershed. This is a reasonable assumption given that the gage TOPG1 watershed is in the Santa Monica Mountains and is likely not as affected by increased imperviousness from higherdensity development, whereas the gages BALC6 and COYC1 watersheds are in areas where imperviousness has likely increased through time. An increase in imperviousness through time would tend to cause an overestimation of streamflow for earlier records and an underestimation of streamflow for more recent records.

\section{Alhambra Wash (gage ALHW6)}

The NSME calibration results for gage ALHW6 on Alhambra Wash were good for daily streamflow and excellent for monthly streamflow, but poor for annual streamflow (fig. 30; table 10). Although the PAEE results of -18 for daily and monthly flow and -14 for annual flow indicated noteworthy estimation bias by an overall underestimation of streamflow, the results were still considered satisfactory in this study. The gage ALHW6 calibration for monthly streamflow provided the greatest NSME value of 0.94 . In general, the hydrographs indicated a better fit to daily and monthly streamflow for the earlier records than the later ones (figs. 30A, B). The annual hydrograph indicated the best fit to the mid-study records, from about water year 1948 to 1991 (fig. 30C). For the annual flows, the model consistently overestimated streamflow prior to about water year 1948 and consistently underestimated streamflow after water year 1991. This temporal drift in estimation bias was consistent with the drift in estimation bias for gages BALC6 and COYC1 and can be explained by an increase in impervious land cover caused by increasing urbanization through time.

\section{San Jose Creek (SJCE1)}

Calibration results for gage SJCE1 ranged from good to excellent in terms of the NSME statistic, with the best fit being achieved for monthly streamflow (fig. 31; table 10). Similar to the results for gage ALHW6, the PAEE statistic of -16 to -15 indicated a tendency for the model to underestimate streamflow at this gage. The daily hydrograph indicated some over- and underestimation of peak flows, and the annual hydrograph indicated a general tendency of the model to underestimate annual flows. The monthly hydrograph indicated that streamflow was primarily underestimated during low-flow conditions, when managed flows from upstream reservoir operations can be the primary source of streamflow. The consistent underestimation during low flows caused the PAEE statistic to be only satisfactory for this gage; otherwise, there was a very good match to the peak daily and monthly flows.

\section{Monthly Streamflow}

Comparison of the scatterplots of simulated against measured monthly streamflow for each gage relative to the one-to-one line was used for a qualitative assessment of model calibration. The scatterplots indicated a good overall fit between simulated and measured monthly streamflow at most streamflow-gaging stations (fig. 32). The best fit to the one-to-one line was indicated by the simulated monthly streamflows for the BALC6, SJCE1, and COYC1 gages. Although gage ALHW6 had the best monthly NSME result at 0.94 , the scatterplot indicated a systematic underestimation of the higher monthly flows. The poorest calibration result was indicated for gage TOPG1, which showed a consistent underestimation of the higher monthly flows. 
A

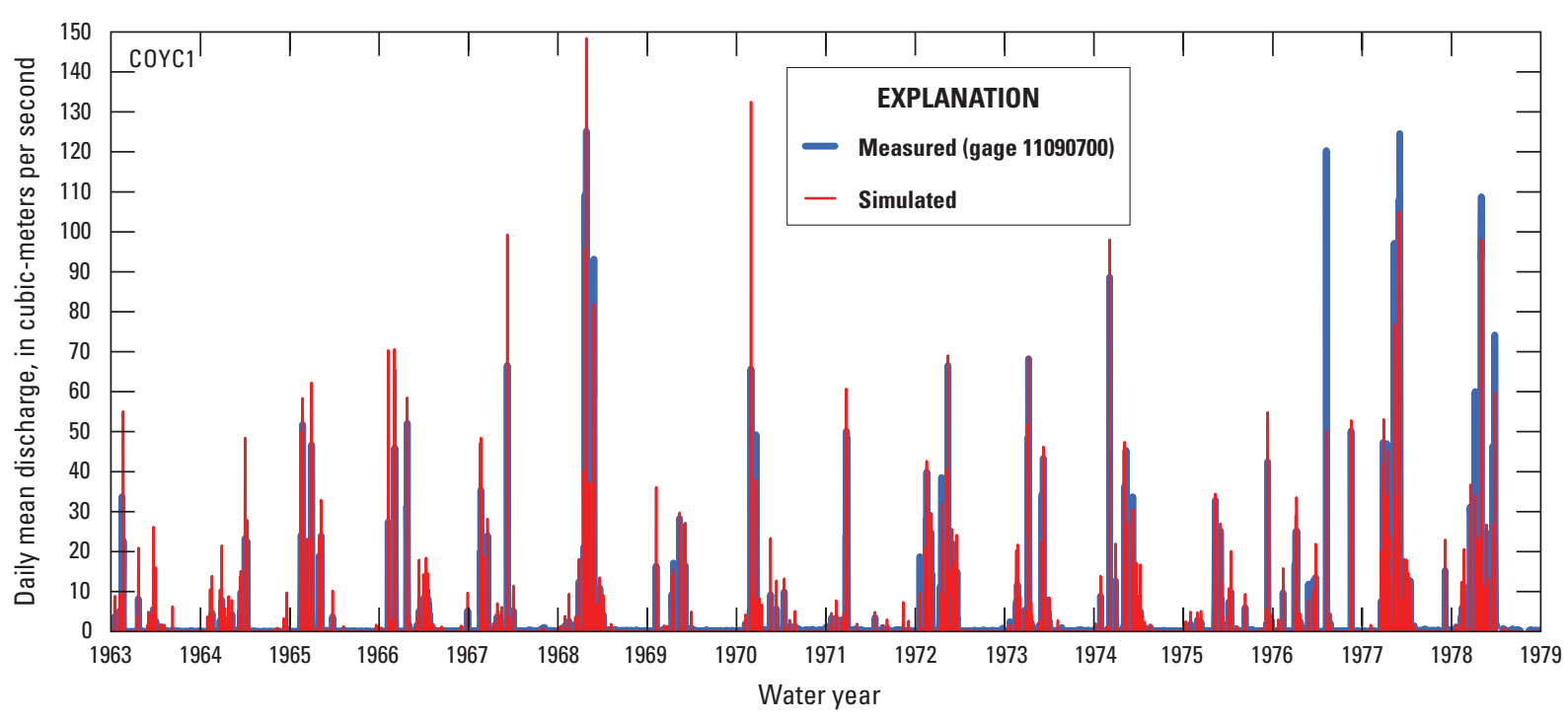

B

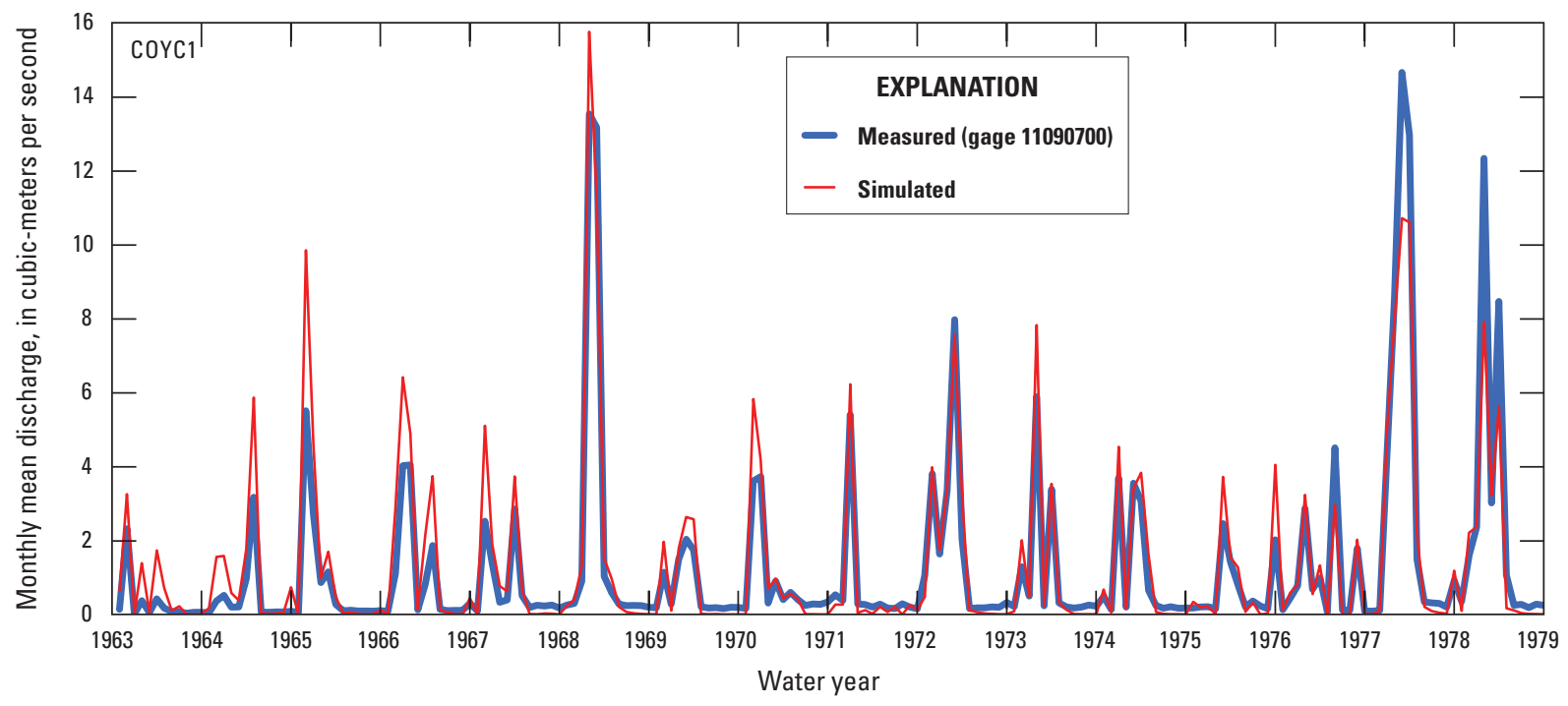

C

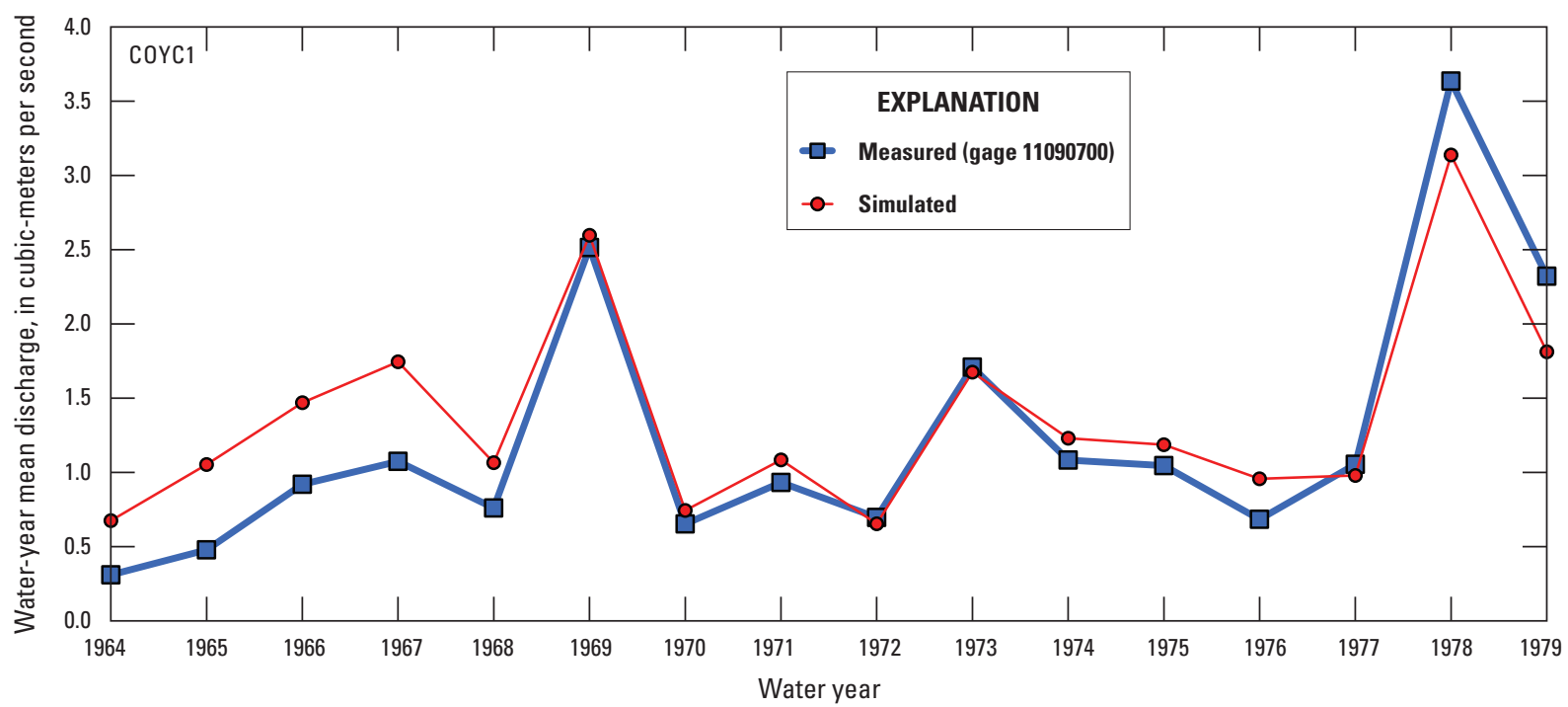

Figure 28. Comparison of simulated and measured streamflow at gage COYC1, Los Angeles Basin watershed model (LABWM), California: $A$, daily; $B$, monthly; $C$, annually. 
$\boldsymbol{A}$

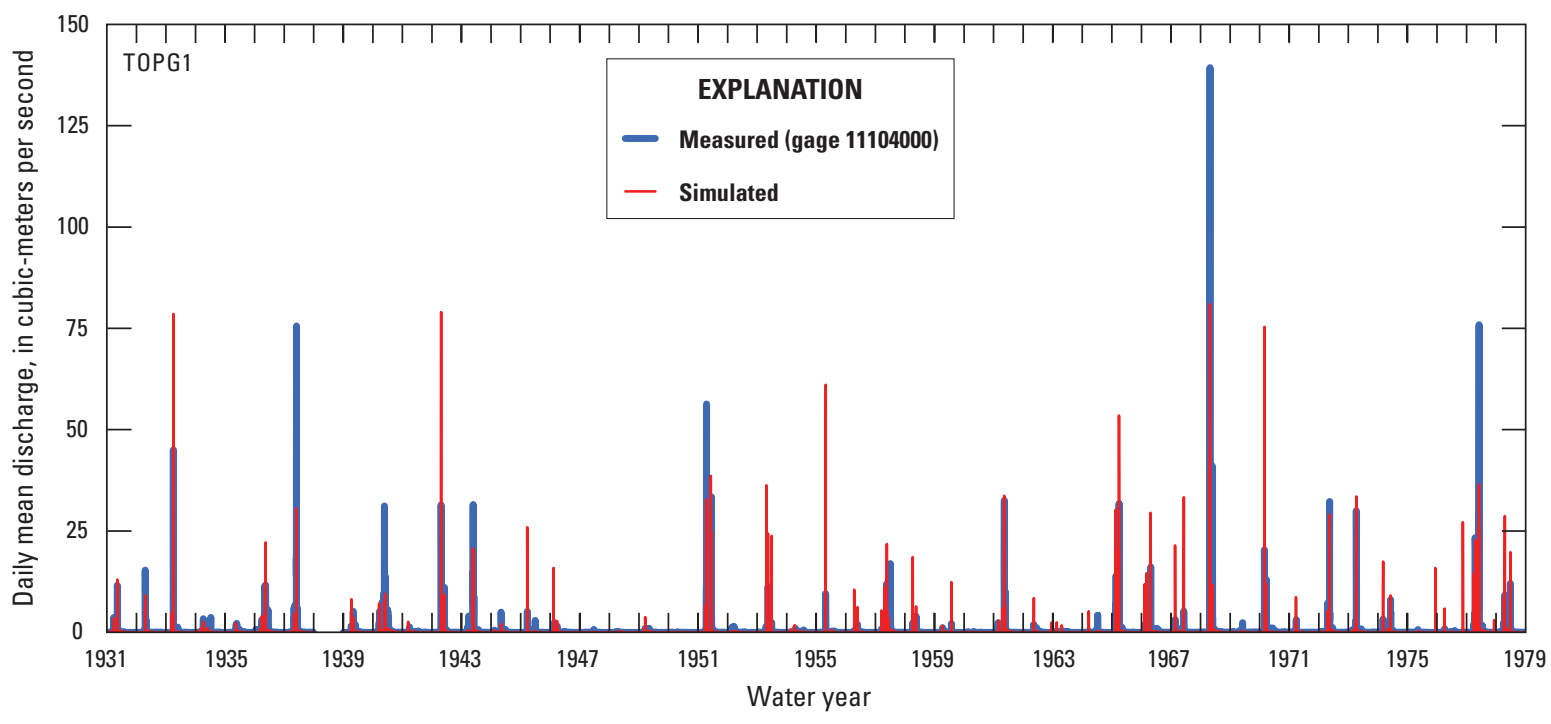

B

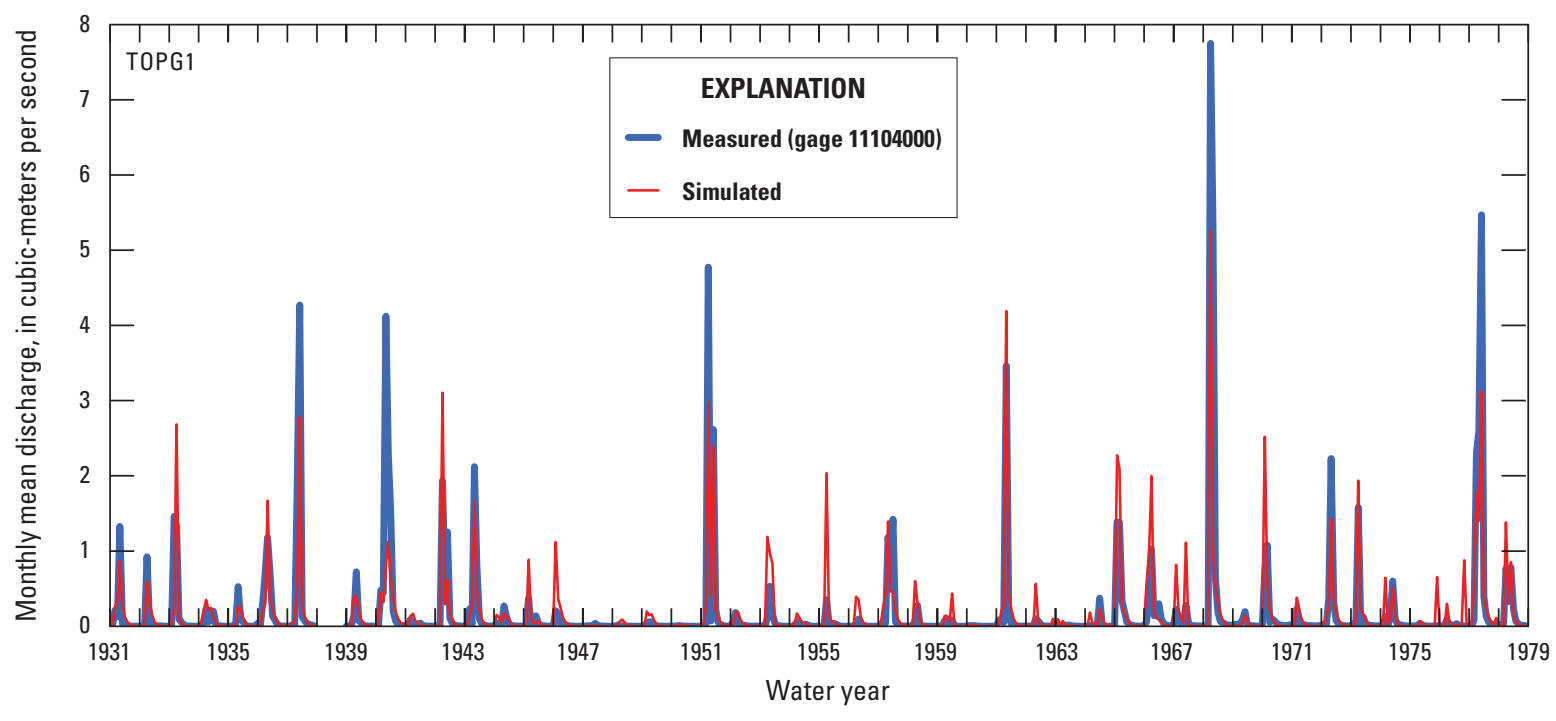

C

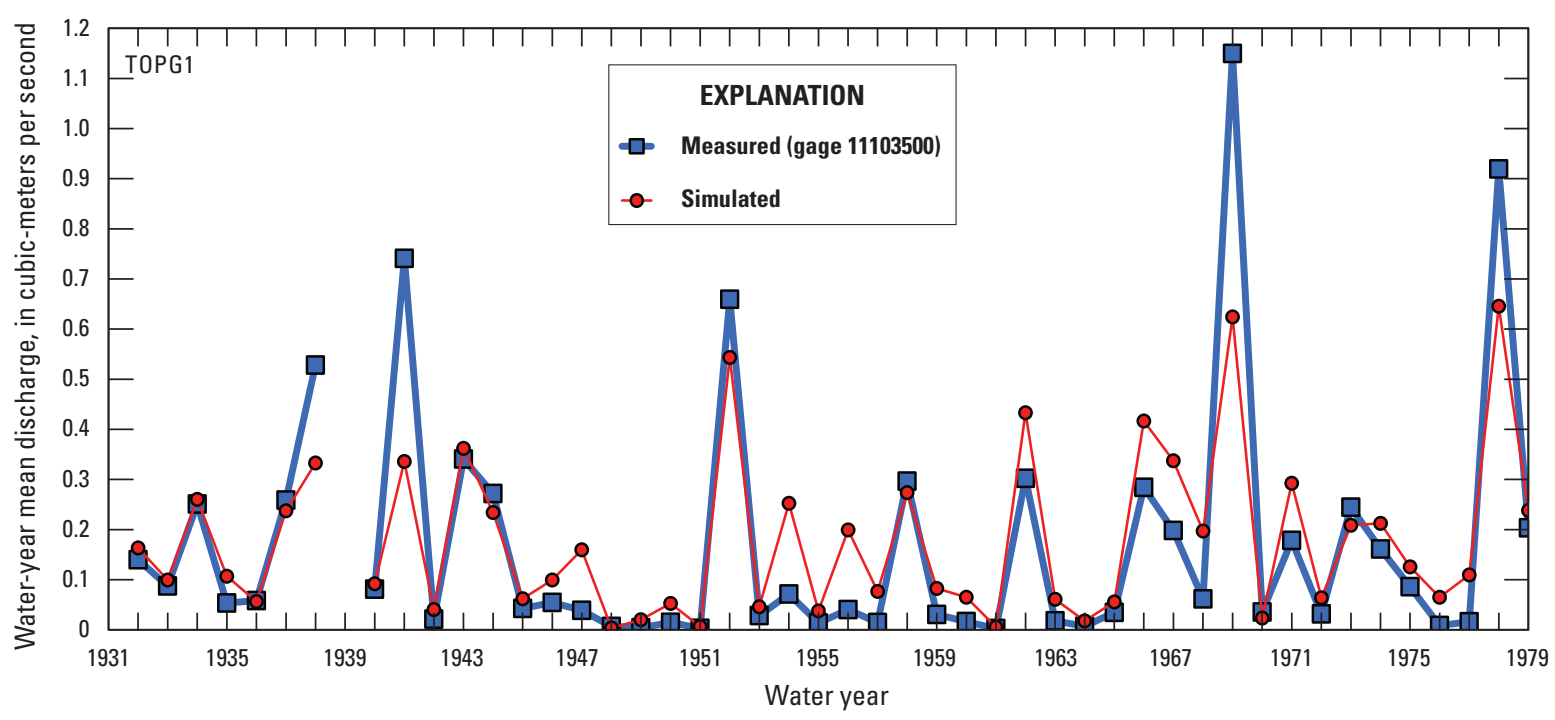

Figure 29. Comparison of simulated and measured streamflow at gage TOPG1, Los Angeles Basin watershed model (LABWM), California: $A$, daily; $B$, monthly; $C$, annually. 

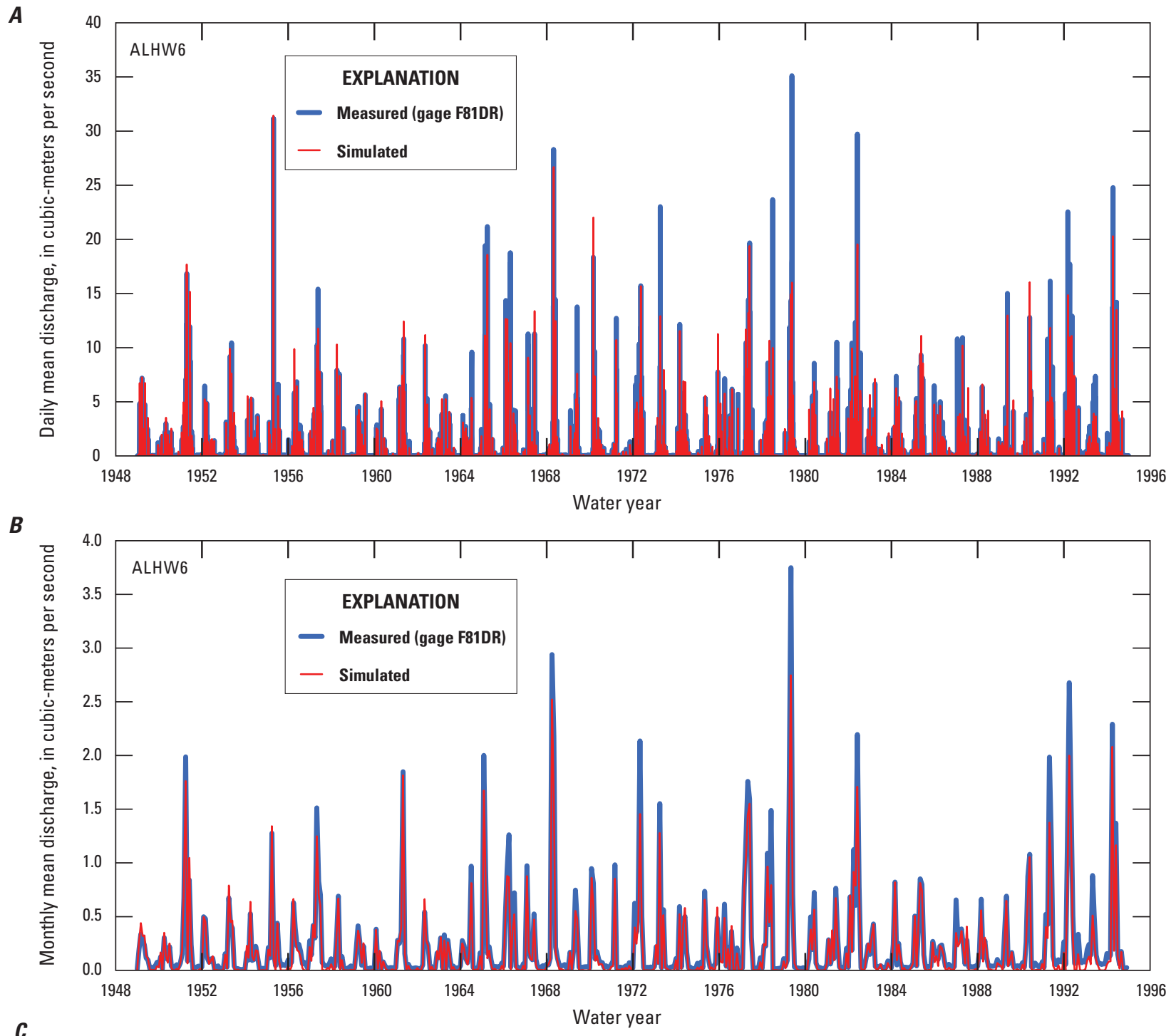

C

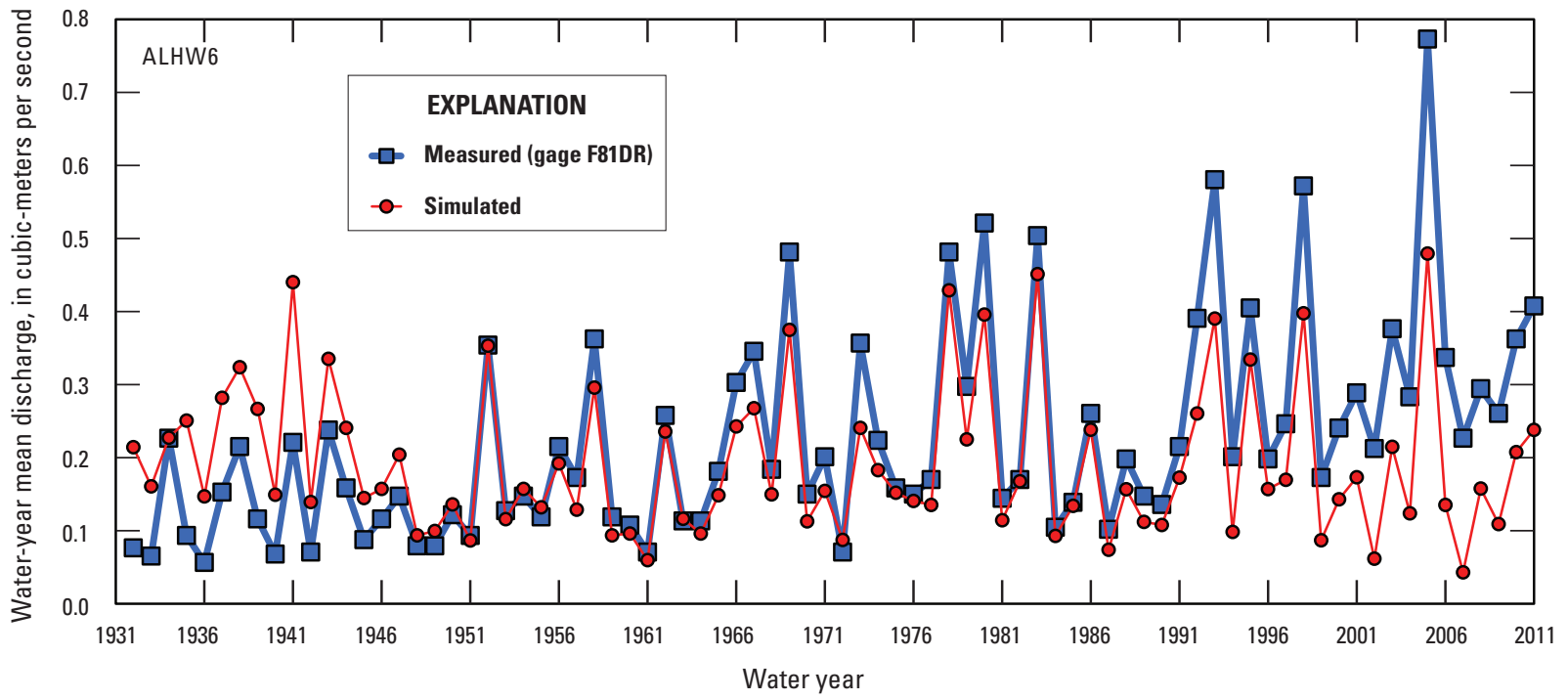

Figure 30. Comparison of simulated and measured streamflow at gage ALHW6, Los Angeles Basin watershed model (LABWM), California: $A$, daily; $B$, monthly; $C$, annually. 
$\boldsymbol{A}$
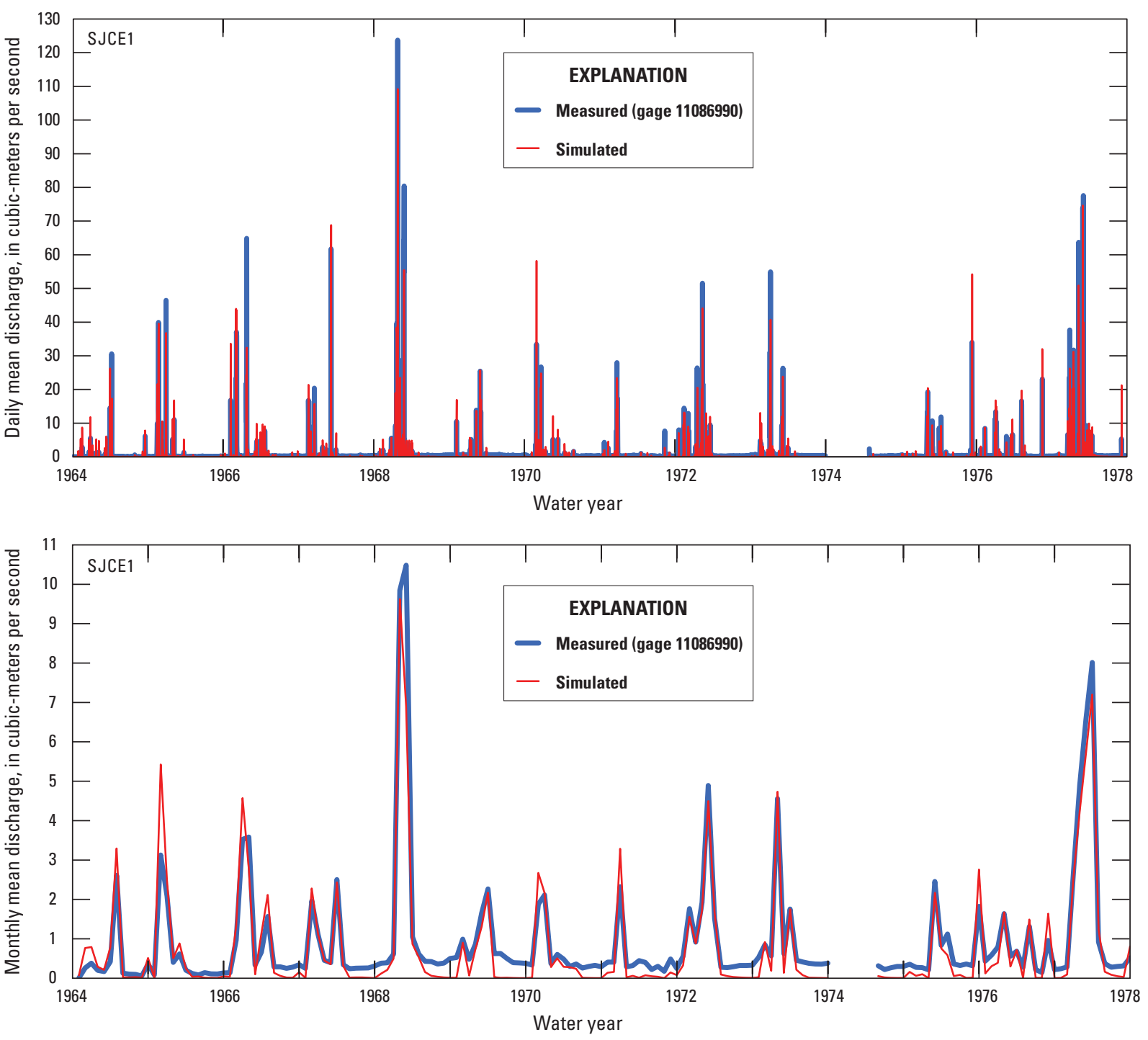

C

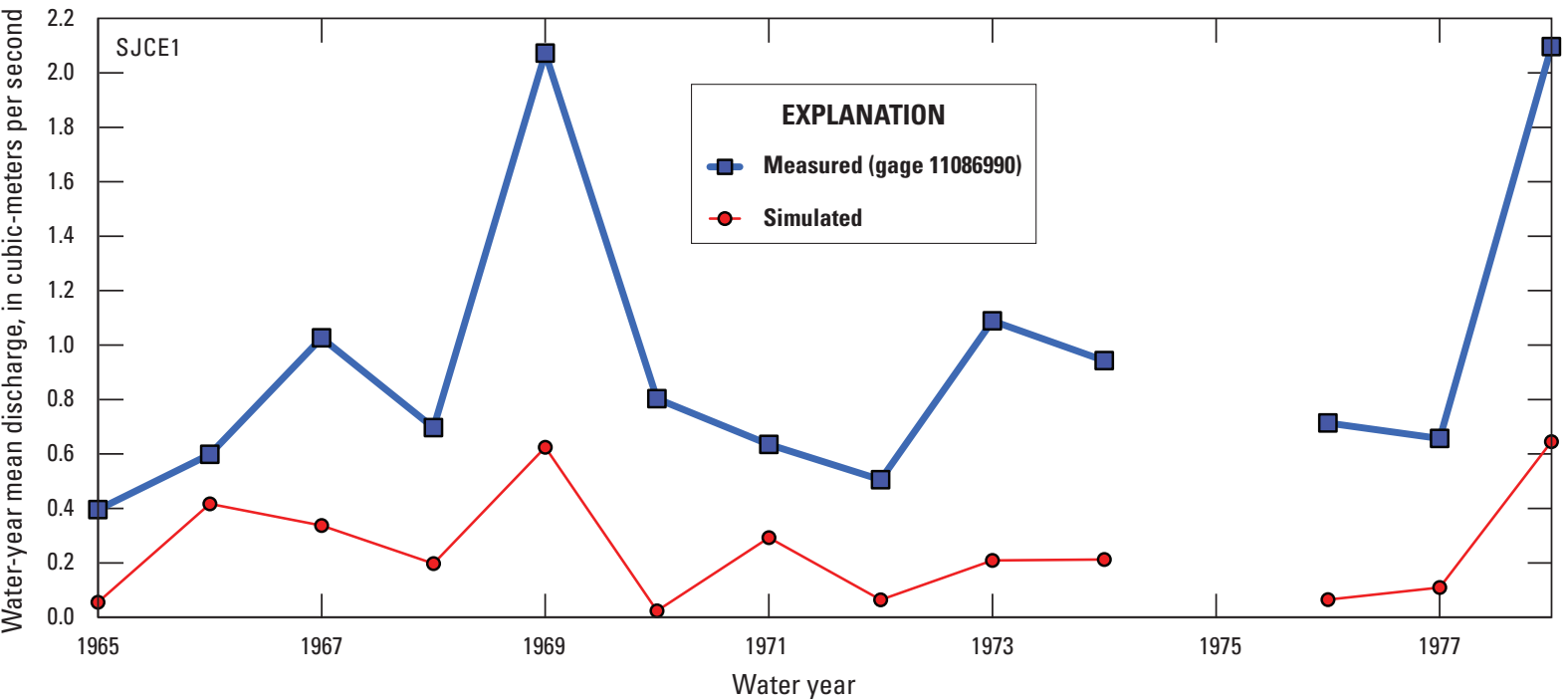

Figure 31. Comparison of simulated and measured streamflow at gage SJCE1, Los Angeles Basin watershed model (LABWM), California: $A$, daily; $B$, monthly; $C$, annually. 

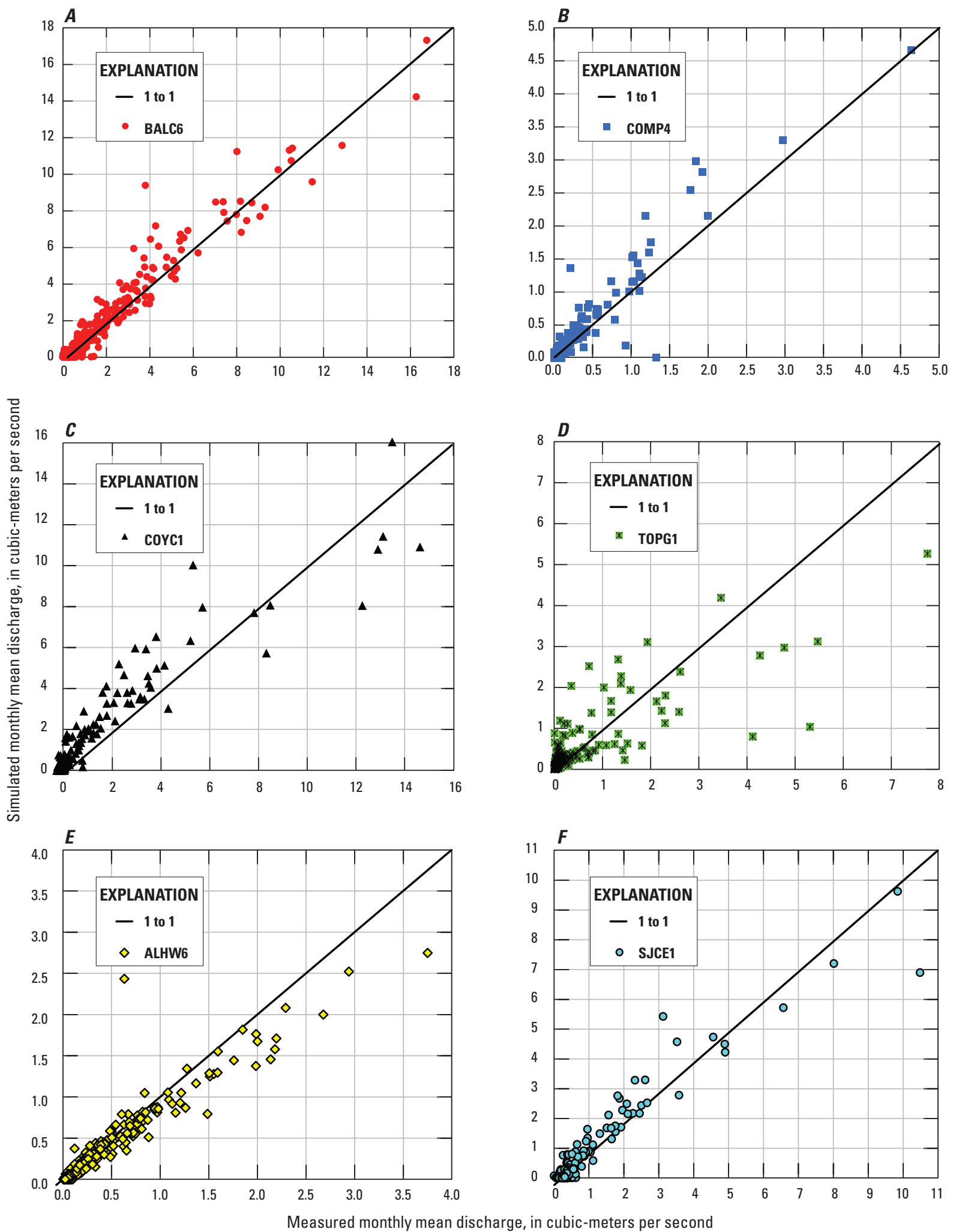

Figure 32. Simulated against measured monthly streamflow, Los Angeles Basin watershed model (LABWM), California, at gage $A$, BALC6; $B$, COMP4; $C$, COYC1; $D$, TOPG1; $E$, ALHW6; F, SJCE1. 


\section{Annual Streamflow}

Comparison of the scatterplots of simulated against measured annual (water year) streamflow to the one-to-one line for each gage also was used for a qualitative assessment of model calibration (fig. 33). The scatterplot provided an indication of the combined calibration based on all six gages. The results indicated a strong correlation between simulated and measured flows, and a good overall fit to the one-to-one line. A slight tendency of the LABWM to underestimate the largest annual streamflows was indicated by the results for gage BALC6 (fig. 33A). Overall, the combined results did not indicate a strong bias in terms of a systematic over- or underestimation of annual streamflow, except at the very low annual streamflows of 0.5 cubic meters per second $\left(\mathrm{m}^{3} / \mathrm{s}\right)$ and less measured at gage TOPG1, which the LABWM showed a tendency to systematically overestimate (fig. 33B).

\section{Model Sensitivity}

A quantitative model-sensitivity analysis was not performed in this study. A qualitative analysis of model sensitivity was done as part of the calibration procedure, however. Simulated streamflow was found to be sensitive to estimated root-zone thickness, soil hydraulic conductivity, percentage of impervious area, and precipitation type (rain or snow). Areas that had a thinner soil cover (generally the undeveloped mountainous areas), lower soil hydraulic conductivity, and higher percentage of impervious area generated greater runoff. In addition, runoff generation (the overland-flow component of streamflow) was found to be sensitive to the estimated hydraulic conductivity for layer 6 (parameters defined in part by surficial geology). Low values of hydraulic conductivity for layer 6 resulted in a greater potential for the generation of saturation excess (Dunnian) runoff.

The seepage-flow component of simulated streamflow, used in this study to represent baseflow, was found to be sensitive to the estimated hydraulic conductivity for layers 6 and 7 and slope. A greater hydraulic conductivity and slope resulted in more seepage (and less overland flow). Parameter values that increased seepage tended to also decrease the runoff component of streamflow.

Simulated recharge was found to be most sensitive to soil thickness and the estimated hydraulic conductivity for layers 6 and 7. In general, parameter values causing an increase in recharge also resulted in a decrease in runoff along with a decrease in ET. Runoff, recharge, and ET were all very sensitive to spatially interpolated precipitation. The effect of air temperature on the simulation of precipitation as rain or snow was also found to be a critical input for the higher elevation drainages in the San Gabriel Mountains. Precipitation as rain caused an increase in streamflow in direct response to the storm event. Precipitation as snow caused a delayed response in runoff and recharge and usually resulted in lower streamflow than if the precipitation had been rain. Unlike soil thickness and hydraulic conductivity, precipitation and air temperature were not adjusted during the calibration process.

\section{Calibration Summary}

Results for four gages, ALHW6, SJCE1, BALC6, and $\mathrm{COYC} 1$, indicated a change in estimation bias from overestimating streamflow in the early part of the record to underestimation of streamflow in the later part of the record. The observed shift in estimation bias was likely to have been caused by changes in watershed characteristics for which the model did not account. For example, an increase in imperviousness caused by the growth of urbanized areas and developed lands would tend to cause an increase in runoff during storms. Other factors that could cause an increase in runoff during storms include loss of vegetation due to fire or land development and the conversion of natural channels to engineered channels. In addition to an increase in storm runoff, urbanization and land development can cause an increase in low flows in response to wastewater discharges and increased irrigation runoff during the dry months. The development of flood-control features, flow diversions, and spreading grounds also cause changes in the flow characteristics of a watershed. In some cases, the storage of storm runoff in reservoirs upstream from the stream gage used for calibration can result in a reduction in water-year runoff because of evaporation and seepage losses from reservoirs. For this study, however, a consistent trend of decreasing wateryear runoff was not identified by using the average water year runoff for the six calibration gages.

\section{Model Application}

By using the calibrated LABWM, simulations were run for the 12 model subdomains (fig. 9). The daily simulation period was January 1, 1905, to September 30, 2014, and included a 9.75 year model-initialization period (January 1, 1905, through September 30, 2014) and a 100-year targetsimulation period for water years 1915-2014 (October 1, 1914, through September 30, 2014). Results from the 12 model subdomains were combined to develop maps of average annual values and average monthly values for various components of the simulated water budget. The combined results were used to calculate the total potential recharge in the Los Angeles recharge-study area, including the direct recharge component in the LAGSA as well as the mountain-front recharge component from tributary upland areas bordering the LAGSA. 
$\boldsymbol{A}$

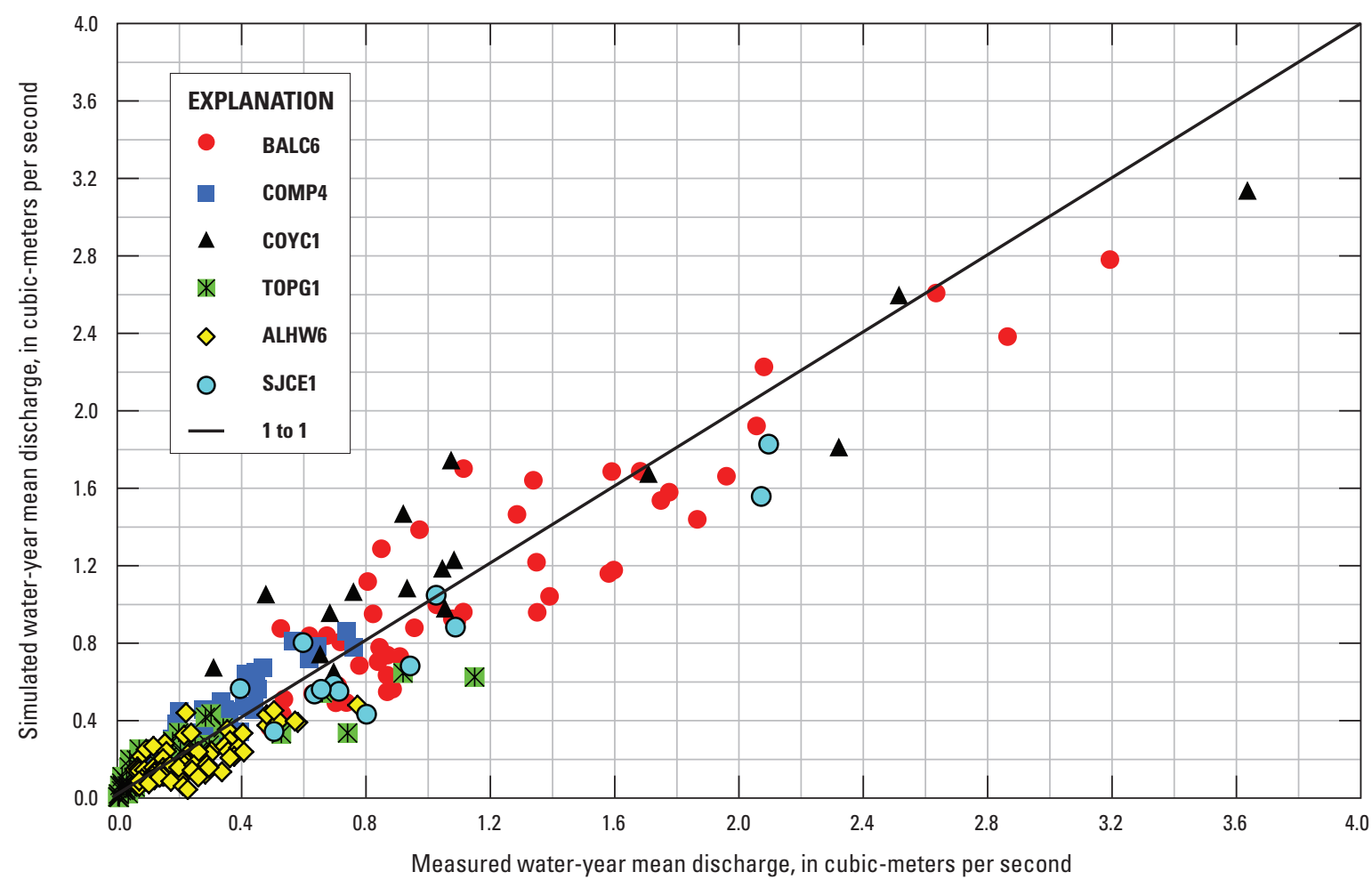

B

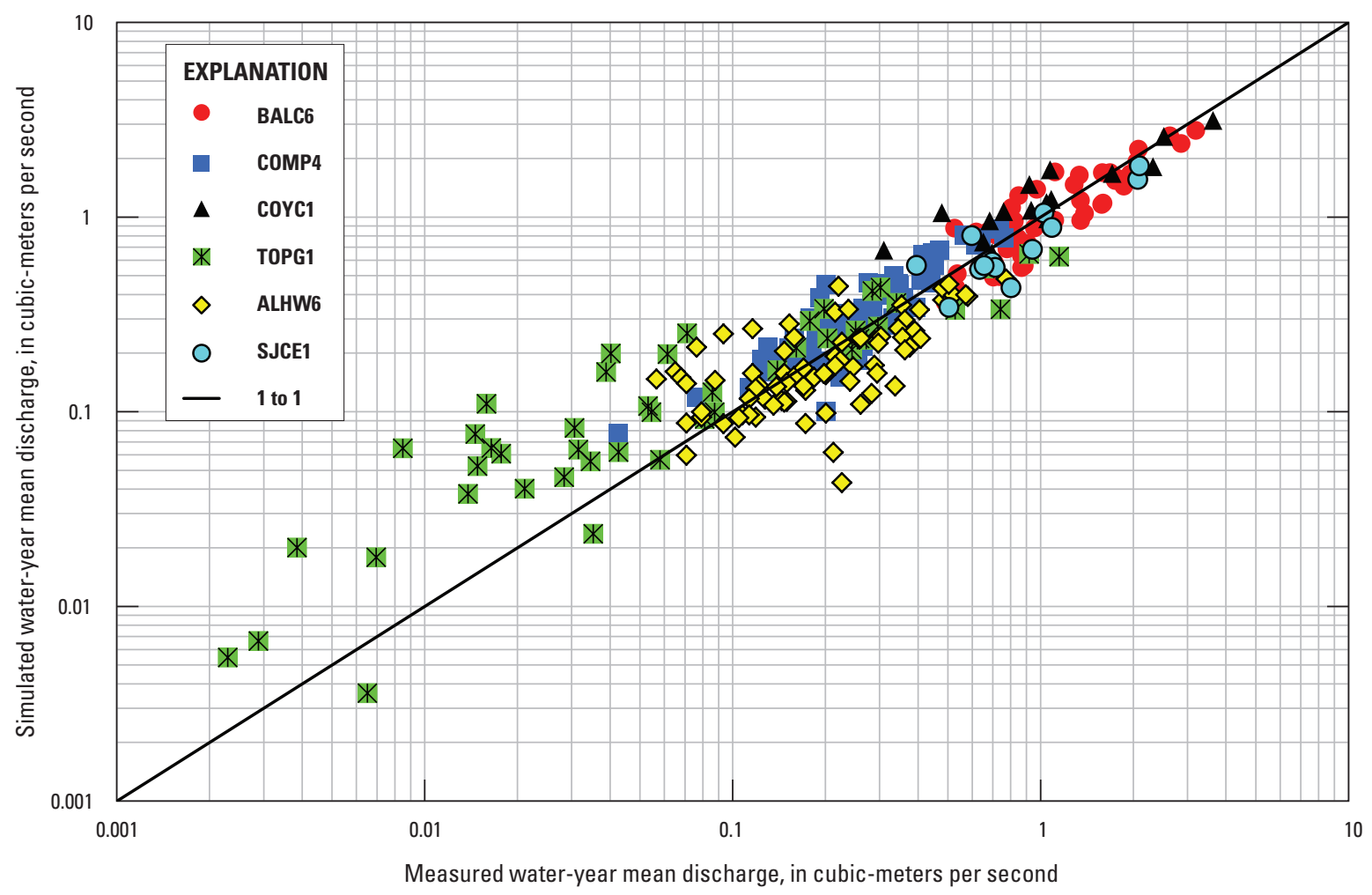

Figure 33. Simulated against measured annual streamflow at six gages used for model calibration, Los Angeles Basin watershed model (LABWM), California: $A$, normal scale; $B$, log-scale. 


\section{Simulation Results, Water Years 1915-2014}

Simulation results for water years 1915-2014 were used to map the 100-year averages for components of the water budget, including PET, ET, streamflow, and recharge. The mapped results were used to analyze the distribution patterns of the water-budget components and to identify areas of maximum and minimum values.

\section{Potential Evapotranspiration}

Simulated average annual PET for water years 19152014 ranged from high values of 1,437 mm/yr for low-lying, south-facing slopes in the hilly and mountainous regions of the LABWM area to low values of $550 \mathrm{~mm} / \mathrm{yr}$ for the steeper, north-facing slopes in the San Gabriel Mountains (fig. 34). A basin-wide average PET rate of $1,237 \mathrm{~mm} / \mathrm{yr}$ was simulated for the LABWM area (table 11). The average PET for subbasins ranged from a minimum of $1,188 \mathrm{~mm} / \mathrm{yr}$ for the upper San Gabriel River to a maximum of 1,274 mm/yr for Rio Hondo. Lower PET rates were simulated for the coastal areas compared to the inland areas. The overall distribution of simulated PET was comparable to published reference ET $\left(\mathrm{ET}_{\mathrm{o}}\right.$ ) zones 4, 6, 9, and 14 for California (California Irrigation Management Information System (CIMIS), 2005), showing reference $\mathrm{ET}_{\mathrm{o}}$ of about 1,450 mm/yr for inland areas (zone 14) and 1,180 $\mathrm{mm} / \mathrm{yr}$ for the Los Angeles urban area (zone 4).

A basin-wide average PET rate of 1,258 mm/yr was simulated for the LAGSA (table 12). In general, the differences in basin-wide average PET among the groundwater basins were small, with a maximum PET of $1,285 \mathrm{~mm} / \mathrm{yr}$ simulated for the Whittier Area groundwater basin and a minimum of $1,240 \mathrm{~mm} / \mathrm{yr}$ simulated for the Santa Monica groundwater basin.

\section{Evapotranspiration}

The highest maximum ET rates of 701 to $1,104 \mathrm{~mm} / \mathrm{yr}$ were simulated for south-facing slopes in the San Gabriel and Santa Monica Mountains, and also for irrigated pervious cells in urban areas (fig. 35). The lowest ET rates of 0 to $100 \mathrm{~mm} / \mathrm{yr}$ were simulated for impervious areas of urban centers and also for water bodies (the LABWM does not simulate evaporation from water bodies or impervious surfaces). The 100-year basin-wide average ET rate simulated for the LABWM area was $362 \mathrm{~mm} / \mathrm{yr}$ (table 11), and the 100-year basin-wide average ET rate simulated for the LAGSA was $297 \mathrm{~mm} / \mathrm{yr}$ (table 12). In the LABWM area, the upper San Gabriel River subdomain had the highest ET rate at $444 \mathrm{~mm} / \mathrm{yr}$, and in the LAGSA, the Whittier Area groundwater basin had the highest ET rate at $380 \mathrm{~mm} / \mathrm{yr}$. In general, the higher ET rates were simulated for the more pervious cells receiving larger precipitation amounts in the mountainous areas, urban irrigation, or a combination of both these things. Compared to other subdomains, the upper San Gabriel River subdomain had the highest 100 -year precipitation rate at $669 \mathrm{~mm} / \mathrm{yr}$ (table 11). Compared to other groundwater basins, the Whittier Area had the highest urban irrigation rate of $184 \mathrm{~mm} / \mathrm{yr}$ (table 12). In the developed and urbanized land areas, higher ET was also simulated for cells downstream from more impervious cells that tended to generate runoff (fig. 35).

\section{Runoff}

Results for runoff included the combined simulated runoff from overland and seepage flows. The average annual simulated runoff for water years 1915-2014 included a maximum runoff of $9.5 \mathrm{~m}^{3} / \mathrm{s}$ simulated for the cells representing the lower reaches of the main channel of the Los Angeles River downstream from the confluence with the Rio Hondo near the mouth of the San Gabriel River (fig. 36). Relatively high average runoff rates up to $2 \mathrm{~m}^{3} / \mathrm{s}$ were simulated for the lower section of Ballona Creek, Rio Hondo, the upper sections of the Los Angeles and San Gabriel Rivers, and near the mouth of the Dominguez Channel. Low to intermediate average runoff rates of 0.11 to $1 \mathrm{~m}^{3} / \mathrm{s}$ were simulated for the tributaries draining into the main channels of the lowlands and also the headwater drainages in the San Gabriel Mountains. Relatively low average annual runoff rates of 0.01 to $0.1 \mathrm{~m}^{3} / \mathrm{s}$ were simulated for the first- and secondorder drainages represented by the majority of the stream channels in the LABWM area. The average-annual runoff rate simulated for the LABWM area was $145 \mathrm{~mm} / \mathrm{yr}$, which was about 30 percent of the average annual precipitation rate and 26 percent of the combined average inflows from precipitation and urban irrigation (table 11). The upper San Gabriel River subdomain had the highest simulated-runoff rate at 192 mm/yr. In comparison, the lower Santa Monica Basin subdomain had the lowest runoff rate at $84 \mathrm{~mm} / \mathrm{yr}$. The highest surface-water outflow of $812 \mathrm{~mm} / \mathrm{yr}$ was simulated for the lower Los Angeles River subdomain, which included a combined surface-water inflow of $643 \mathrm{~mm} / \mathrm{yr}$ from the upstream subdomains upper Los Angeles River and Rio Hondo in addition to the $169 \mathrm{~mm} / \mathrm{yr}$ runoff generated in the lower Los Angeles River subdomain. The average 100-year runoff simulated for the LAGSA was $140 \mathrm{~mm}$, or about 42 percent of the average precipitation of $336 \mathrm{~mm} / \mathrm{yr}$ (table 12). Excluding the surface-water inflows from the three major surface-water drainages upstream from the LAGSA (the Los Angeles River, the San Gabriel River, and the Rio Hondo), inflow of runoff from mountain-front drainages bordering the LAGSA averaged $24 \mathrm{~mm} / \mathrm{yr}$ for the 100 -year simulation, resulting in a total simulated surface-water discharge of $164 \mathrm{~mm} / \mathrm{yr}$ from the LAGSA. The Hollywood groundwater basin had the highest average surface-water inflow at $136 \mathrm{~mm} / \mathrm{yr}$ and also had the highest average surfacewater discharge at $324 \mathrm{~mm} / \mathrm{yr}$ (table 12). 


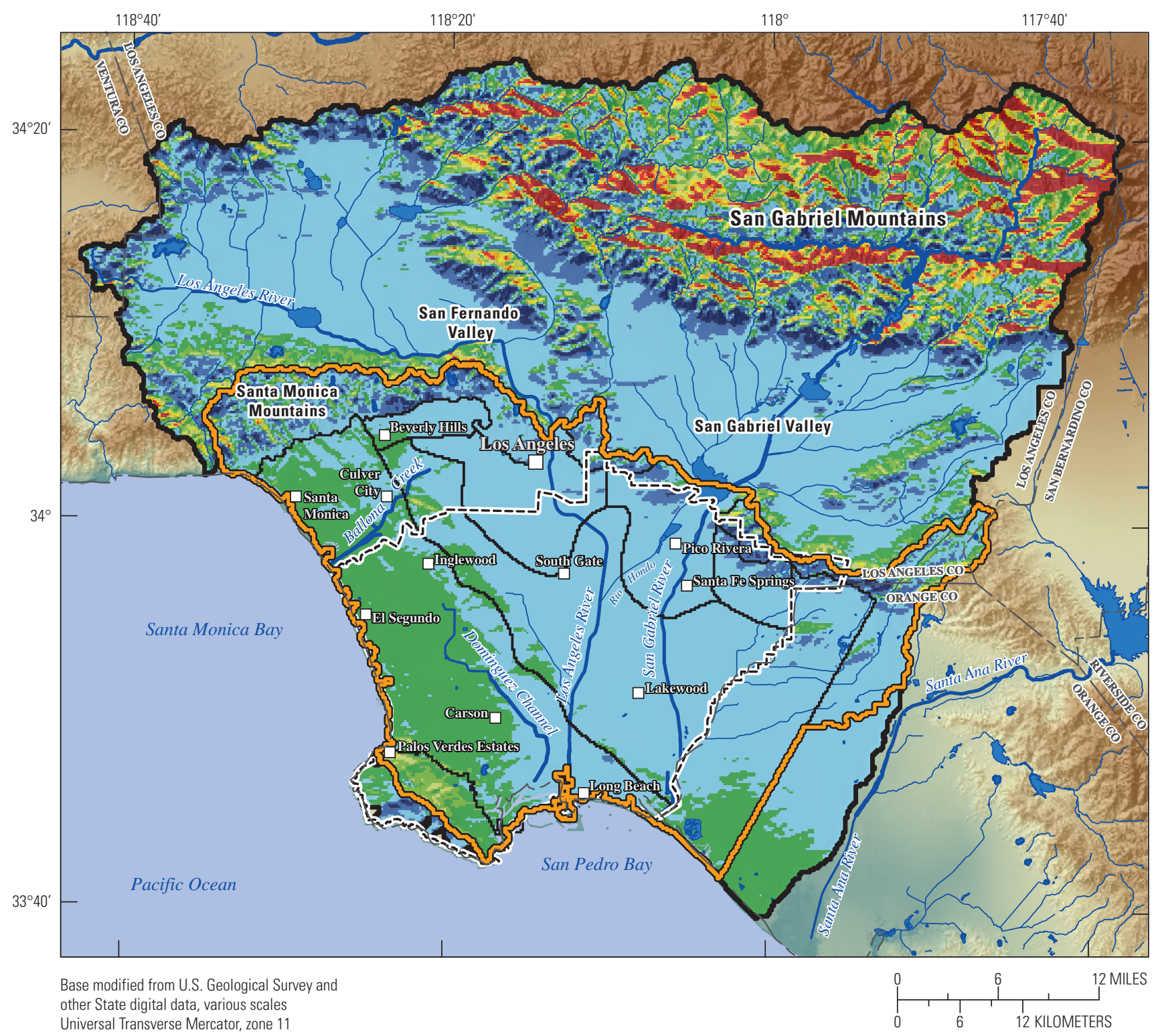

Universal Transverse Mercator, zone 11

North American Datum 1983

\section{EXPLANATION}

\begin{tabular}{|c|c|c|}
\hline \multirow{2}{*}{\multicolumn{2}{|c|}{$\begin{array}{l}\text { Los Angeles Basin watershed model simulated } \\
\text { 1915-2014 potential evapotranspiration, in } \\
\text { millimeters per year }\end{array}$}} & \multirow{4}{*}{$\begin{array}{l}\text { Los Angeles Basin watershed model area boundary } \\
\text { Water Replenishment District } \\
\text { Los Angeles recharge study area } \\
\text { Water bodies and flood-control areas }\end{array}$} \\
\hline & & \\
\hline $550-950$ & \multirow{2}{*}{$1,151-1,200$} & \\
\hline & & \\
\hline | 951-1,000 & $1,201-1,250$ & Major rivers and streams \\
\hline $1,001-1,050$ & $1,251-1,300$ & Minor rivers and streams \\
\hline $1,051-1,100$ & $1,301-1,350$ & Los Angeles groundwater basins \\
\hline $1,101-1,150$ & $1,351-1,437$ & County line \\
\hline
\end{tabular}

Figure 34. Average annual potential evapotranspiration simulated for water years 1915-2014 by using the Los Angeles Basin watershed model (LABWM), California. 


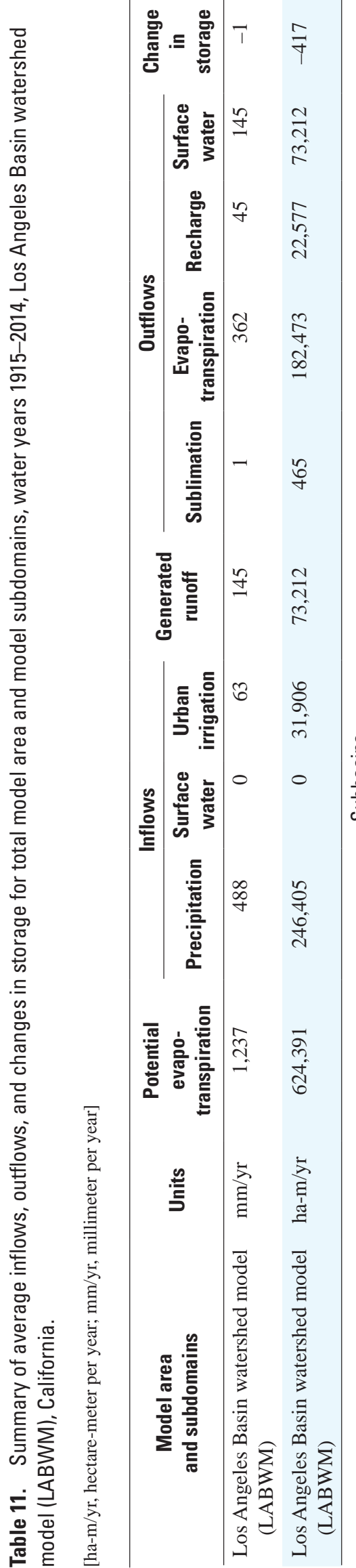

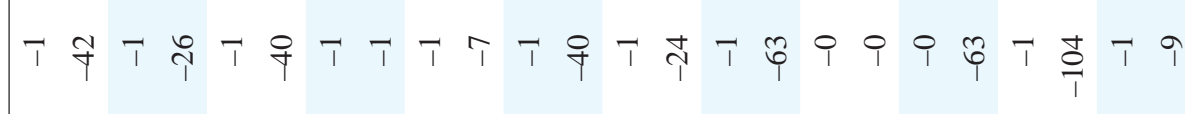

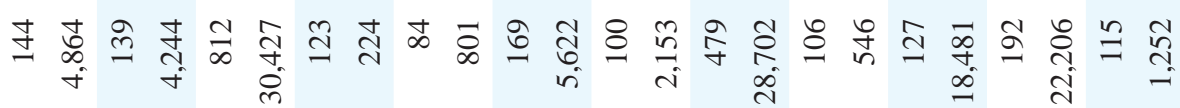

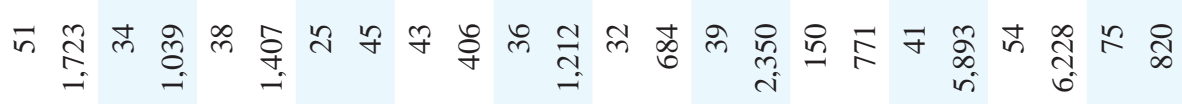

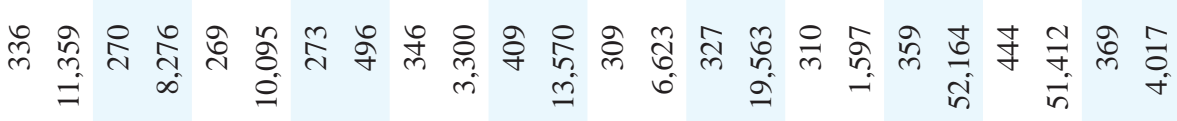

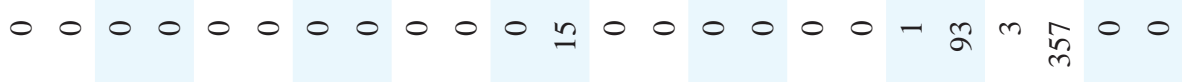

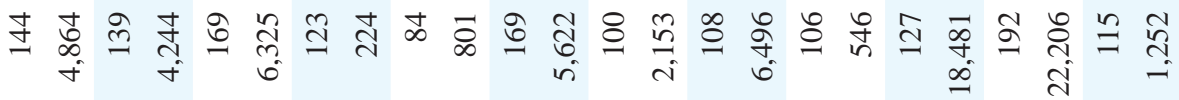

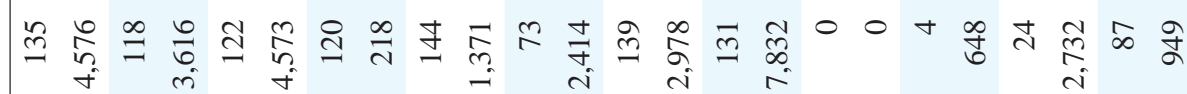

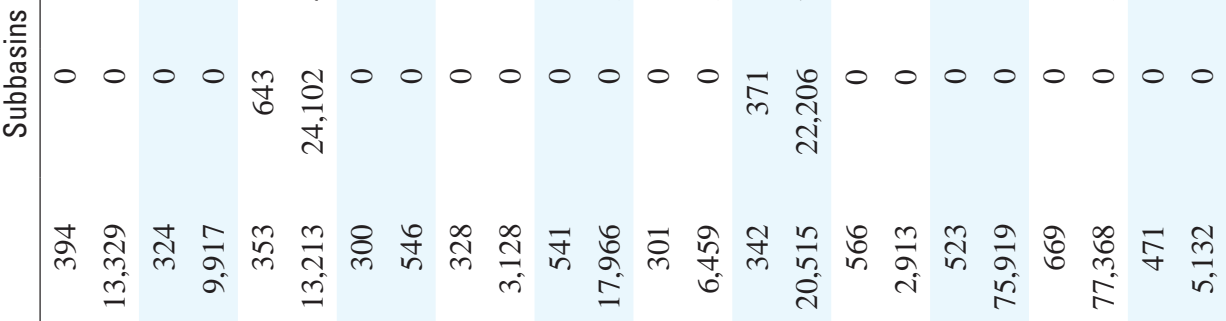

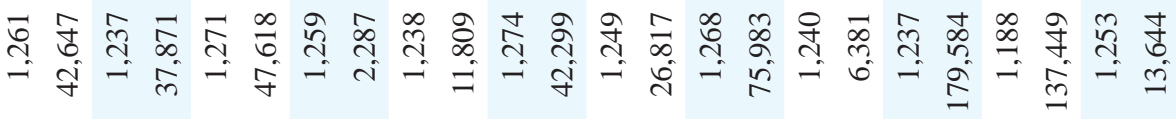

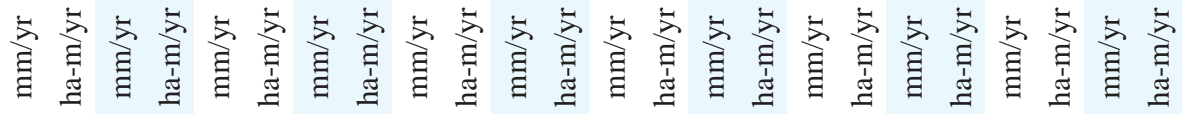

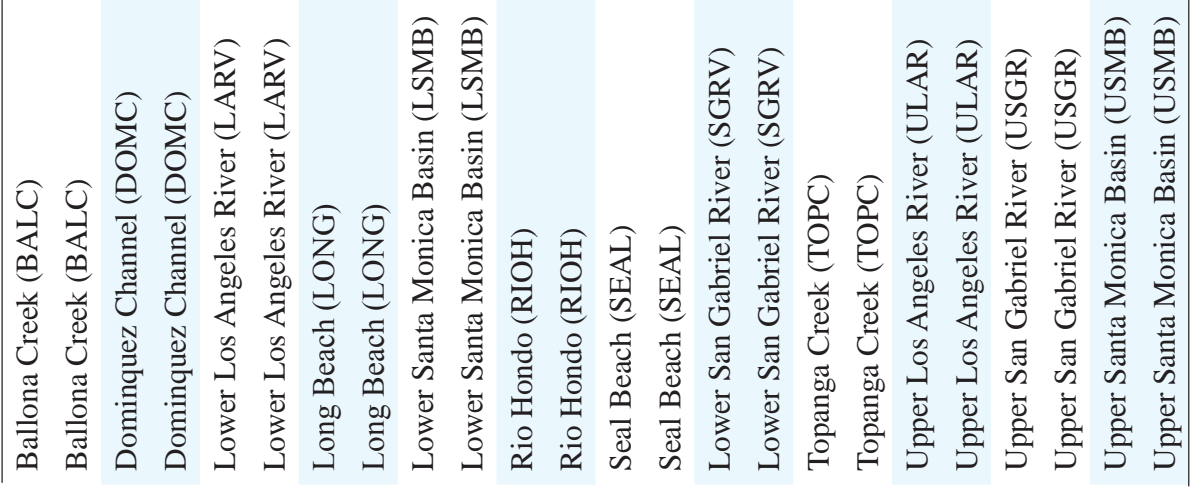




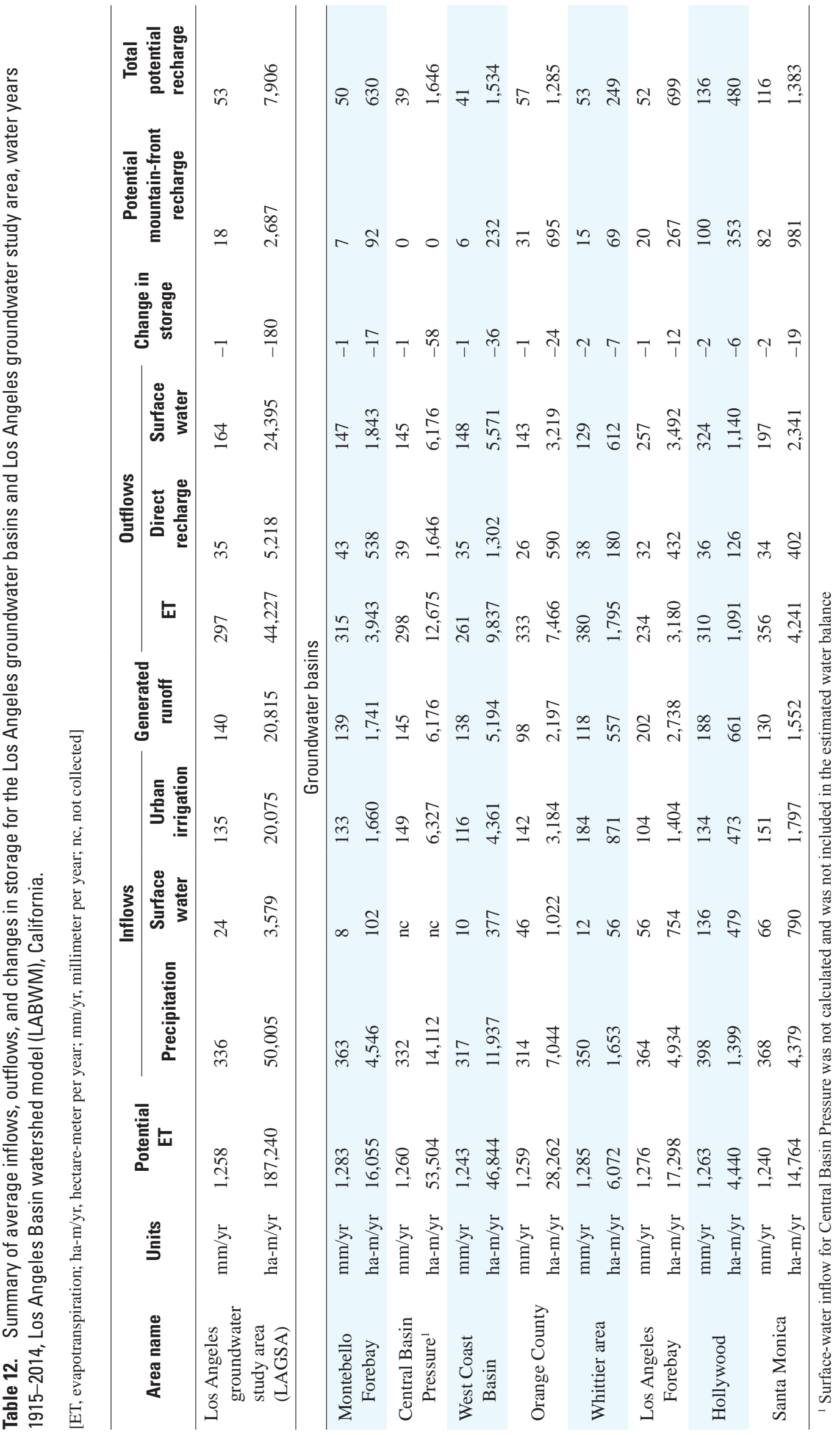




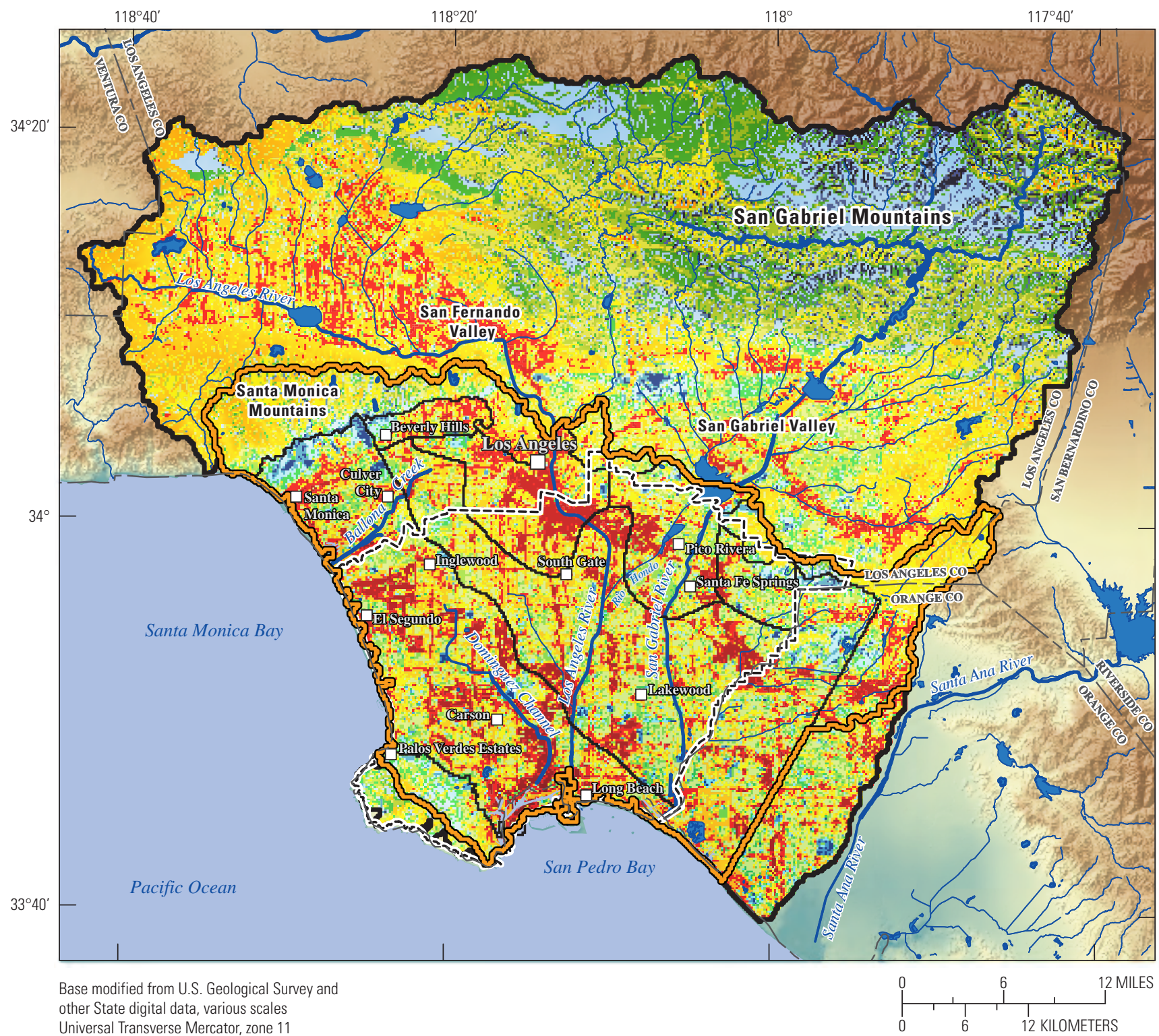
North American Datum 1983

\section{EXPLANATION}

\begin{tabular}{|c|c|c|}
\hline \multirow{2}{*}{\multicolumn{2}{|c|}{$\begin{array}{l}\text { Los Angeles Basin watershed model simulated } \\
\text { 1915-2014 actual evapotranspiration, in } \\
\text { millimeters per year }\end{array}$}} & \multirow{2}{*}{$\begin{array}{l}\text { Los Angeles Basin watershed model area boundary } \\
\text { Water Replenishment District }\end{array}$} \\
\hline & & \\
\hline $0-100$ & $401-450$ & Los Angeles recharge study area \\
\hline & & Water bodies and flood-control areas \\
\hline $101-200$ & $451-500$ & Major rivers and streams \\
\hline $201-300$ & | 501-600 & Minor rivers and streams \\
\hline $301-350$ & $601-700$ & Los Angeles groundwater basins \\
\hline $351-400$ & 701-1,104 & County line \\
\hline
\end{tabular}

Figure 35. Spatially distributed average annual evapotranspiration simulated for water years 1915-2014 by using the Los Angeles Basin watershed model (LABWM), California. 


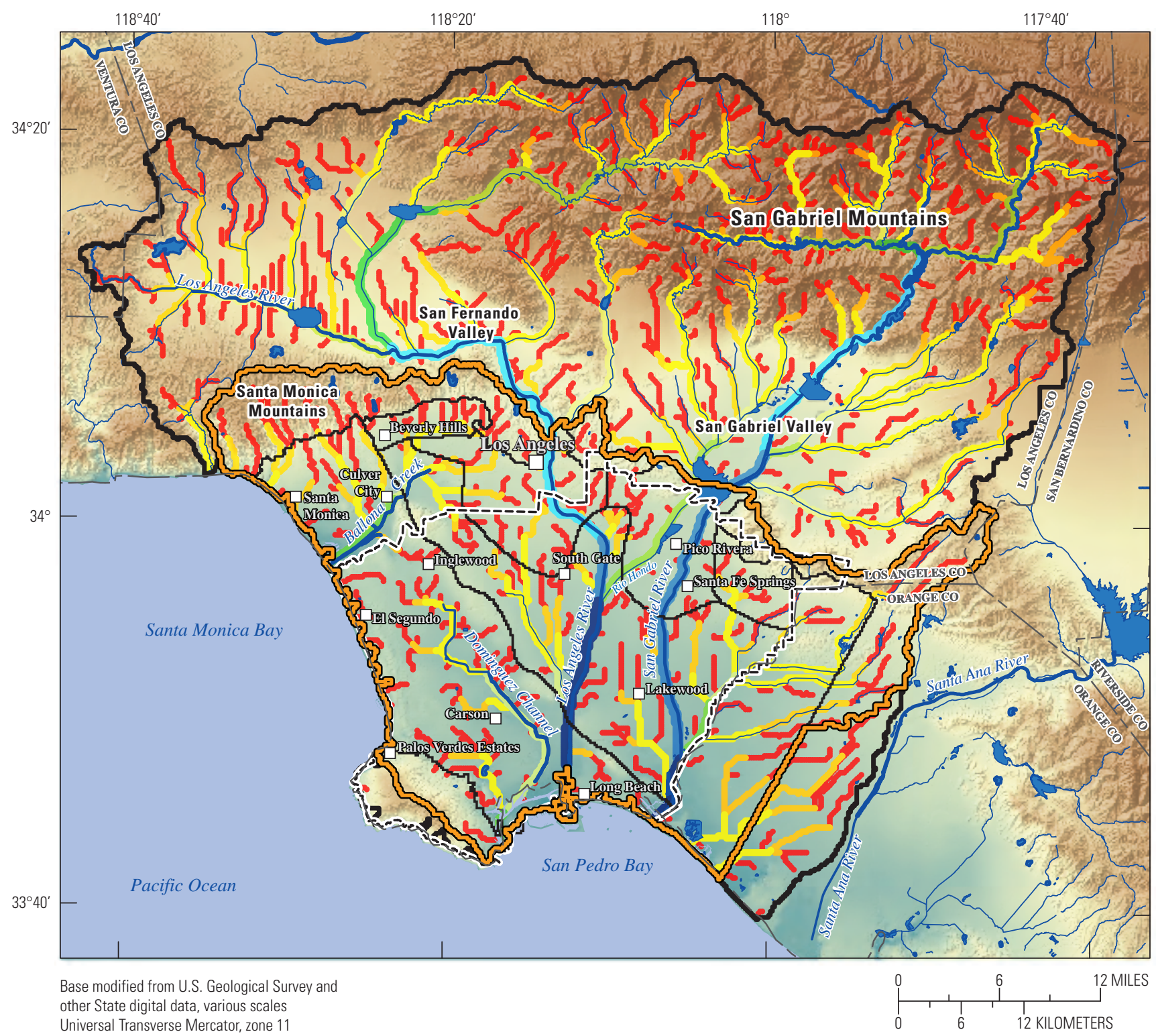

Universal Transverse Mercator, zone 11

North American Datum 1983

\section{EXPLANATION}

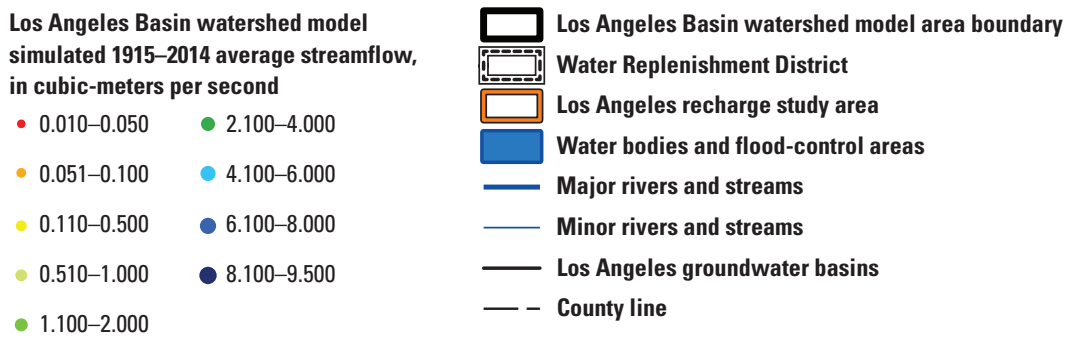

Figure 36. Simulated average streamflow for water years 1915-2014 by using the Los Angeles Basin watershed model (LABWM), California. 


\section{Recharge}

The average-annual simulated recharge for water years 1915-2014 was 45 mm/yr for the LABWM area (table 11). This recharge rate was about 9 percent of the precipitation rate, and about 8 percent of the combined inflow rate of precipitation and urban irrigation. As would be expected, the spatially distributed recharge rate varied notably (fig. 37). The highest average recharge values of 200 to $1,810 \mathrm{~mm} / \mathrm{yr}$ were simulated for stream channels that received large surface-water inflows from upstream areas and also had relatively permeable soil and underlying rock layers. In the low-lying urbanized areas, relatively high recharge rates of more than $50 \mathrm{~mm} / \mathrm{yr}$ were mostly in the irrigated areas subject to frequent inflows from upstream impervious areas in addition to continuous inflows from irrigation. For most low-lying urbanized areas, however, simulated recharge was negligible (less than $1 \mathrm{~mm} / \mathrm{yr}$ ). Recharge tended to be higher in upland areas that have relatively more precipitation and thin soils underlain by permeable rock units. The Topanga Creek subdomain had the highest recharge rate at $150 \mathrm{~mm} / \mathrm{yr}$, about 26 percent of the precipitation rate of $566 \mathrm{~mm} / \mathrm{yr}$ (table 11). The Long Beach subdomain had the lowest recharge rate at $25 \mathrm{~mm} / \mathrm{yr}$, about 6 percent of the combined precipitation and urban irrigation inflow of $420 \mathrm{~mm} / \mathrm{yr}$ (table 11).

The average 100-year simulated direct recharge for the LAGSA was $35 \mathrm{~mm} / \mathrm{yr}$, or about 10 percent of the simulated precipitation and about 7 percent of the total combined inflow of $495 \mathrm{~mm} / \mathrm{yr}$ from precipitation, surfacewater inflow, and urban irrigation (table 12). The directrecharge component only included recharge from the net infiltration of precipitation, irrigation, and surface water through the root zone; it did not account for mountainfront recharge as underflow to the groundwater basin from bordering tributary drainages. In the LAGSA, the Montebello Forebay groundwater basin had the highest simulated direct recharge rate at $43 \mathrm{~mm} / \mathrm{yr}$, whereas the Orange County groundwater basin had the lowest simulated direct recharge rate at $26 \mathrm{~mm} / \mathrm{yr}$.

\section{Annual Results}

\section{Annual Time Series}

The 100-year time series of annual results were used to analyze the temporal variability of the simulated water-budget components for the LABWM area (appendix 1), the Los Angeles recharge-study area (appendix 2), and the LAGSA (appendix 3). With the exception of PET, the annual results for the LABWM area indicated a high degree of year-to-year variability in all components of the water budget (figs. 38A, $B$; appendix 1). Spatially interpolated, basin-wide annual precipitation ranged from a maximum of 566,000 ha-m for water year 2005 to a minimum of about 68,000 ha-m for water year 2007. In addition to water year 2007, three other water years-1961, 2002, and 2014 — had annual precipitation amounts less than 100,000 ha-m. In addition to water year 2005 , five other water years had precipitation greater than 500,000 ha-m: 1941, 1978, 1983, 1993, and 1998. For all 100 water years, simulated basin-wide PET, which varied between about 589,000 and 665,000 ha-m for most water years, was greater than basin-wide precipitation for the LABWM area. After precipitation, the largest component of the LABWM area water budget was ET, which reached a maximum of about 274,000 ha-m during water year 1983 and a minimum of about 103,000 ha-m during water year 2007. In general, ET was strongly correlated to precipitation, but it exceeded precipitation during twenty one water years that had less than average precipitation (for water years 1924-25, 1942, 1948, 1951, 1959-61, 1964, 1970, 1981, 1984, 1987, 1990, 1994, 1999, 2002, 2007, and 2012-14), mostly because of the additional inflows from urban irrigation. Runoff was the third largest component of the LABWM area simulated water budget, with relatively high runoff amounts of more than 200,000 ha-m during the wettest water years: 1941, 1969, $1978,1983,1993$, and 2005. Water year 2005, the wettest year, also had the most runoff at 246,000 ha-m. For many drier than average years, generally less than 200,000 ha-m of precipitation, runoff was less than 50,000 ha-m. Simulated recharge was a much smaller component of the LABWM area water budget compared to simulated ET and runoff. The maximum annual recharge of 85,000 ha-m was simulated for water year 1941, and other relatively high recharge amounts of more than 50,000 ha-m were simulated for water years 1969, 1978, 1980, 1983, 1993, 1998, and 2005 (fig. 38A).

The annual variability in basin-wide water-budget components for the Los Angeles recharge-study area was similar to the basin-wide results for the LABWM area (figs. 38C, D; appendix 2). Water years 1941, 1978, 1998, and 2005 were the wettest for the Los Angeles recharge-study area, with annual precipitation exceeding 150,000 ha-m. Annual ET was highest, more than 70,000 ha-m, during water years 1941, 1958, 1978, 1983, 1993, 1995, 1998, and 2005, all water years with annual precipitation of more than 100,000 ha-m. During the drier years, such as 1948, 1964, 2002, 2007, and 2014, ET was greater than precipitation because of urban irrigation of 24,000 ha-m. The annual runoff was greatest, more than 50,000 ha-m, in water years 1941, 1978, 1983, 1993, 1995, 1998, and 2005, with 2005 having the most runoff at 61,677 ha-m. The annual recharge amounts were highest, more than 20,000 ha-m, during these same water years; however, annual recharge was greatest, 34,000 ha-m, during water year 1941. The 100-year averages for the Los Angeles rechargestudy area included a precipitation rate of 66,928 ha-meters per year (ha-m/yr), an ET rate of 58,021 ha-m/yr, a runoff rate of 24,745 ha-m/yr, and a recharge rate of 7,909 ha-m/yr.

For the LABWM area, the most recharge was simulated for the Topanga Creek (TOPC) subdomain, where annual recharge was as high as $545 \mathrm{~mm}$ for water year 1941 and $535 \mathrm{~mm}$ for water year 2005 (fig. 38E). The upper Santa Monica Basin (USMB) subdomain had the next highest recharge, with annual recharge of $267 \mathrm{~mm}$ for water year 


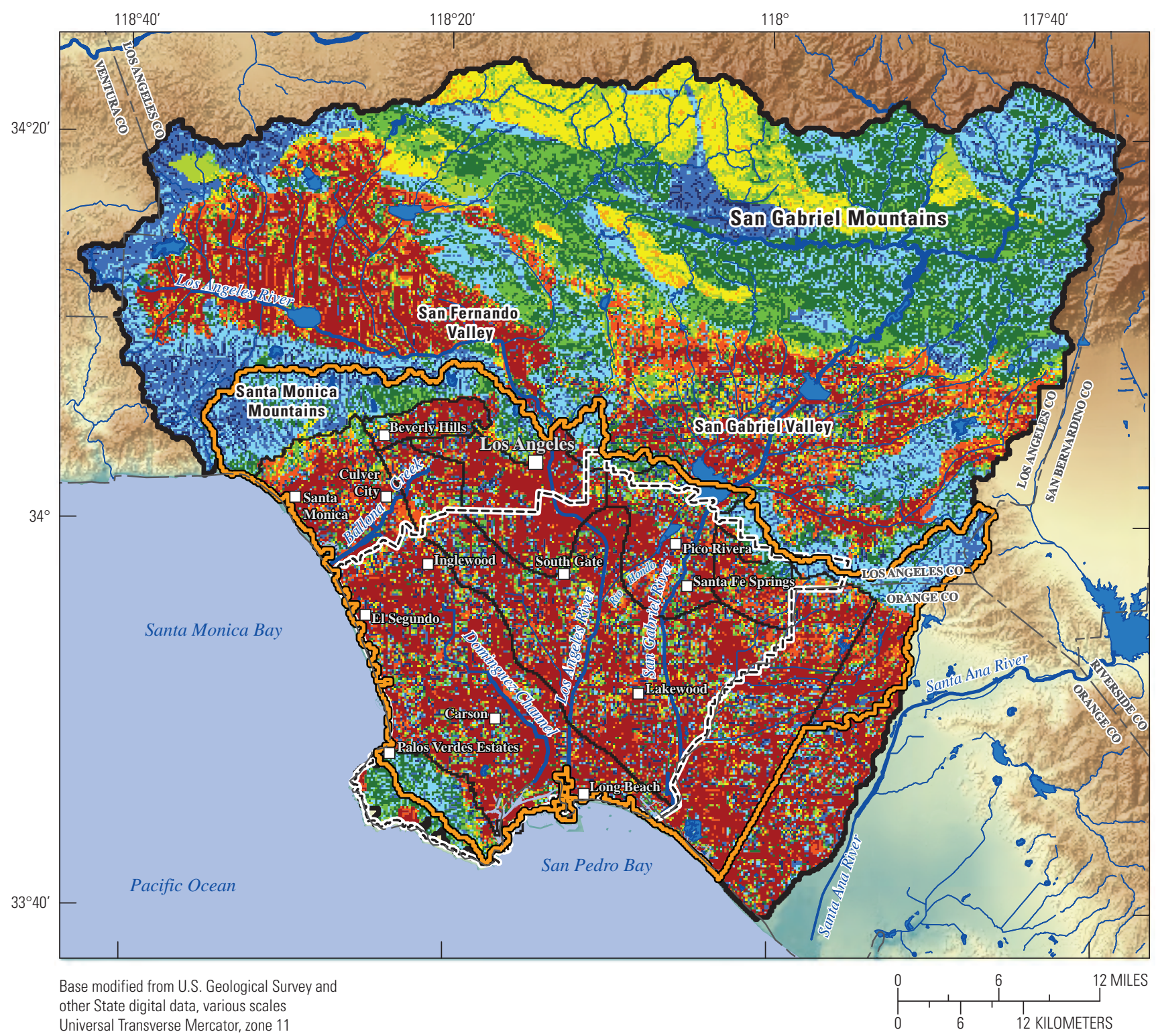

Universal Transverse Mercator, zone 11

North American Datum 1983

\section{EXPLANATION}

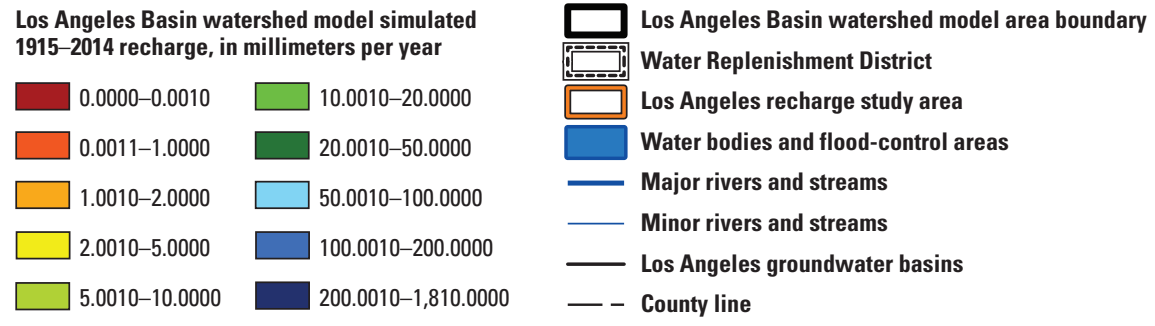

Figure 37. Spatially distributed average annual recharge simulated for water years 1915-2014 using the Los Angeles Basin watershed model (LABWM), California. 


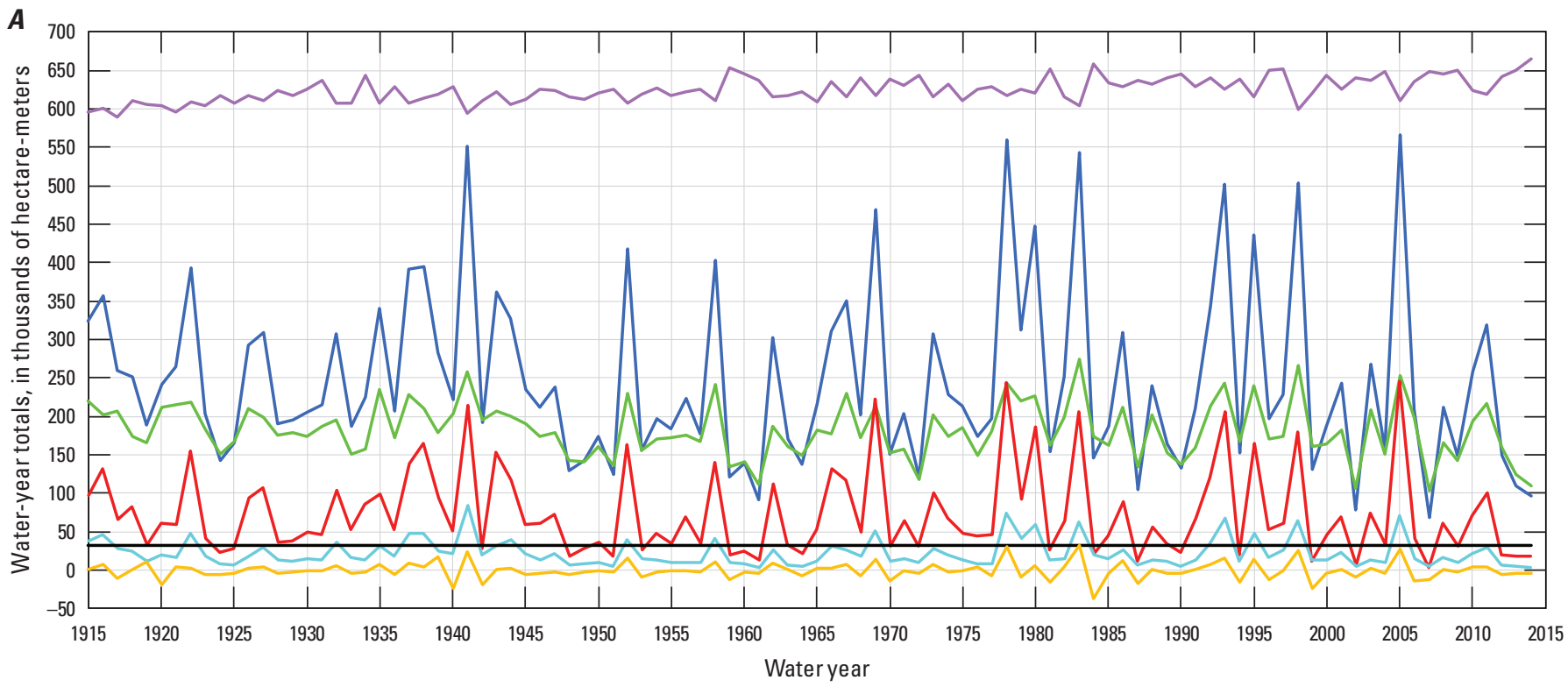

EXPLANATION

$\begin{array}{lll}\text { - Precipitation } & \text { Runoff } & - \text { Urban irrigation } \\ \text { Evapotranspiration } & - \text { Recharge } & - \text { Root-zone water-content change }\end{array}$

- Potential evapotranspiration

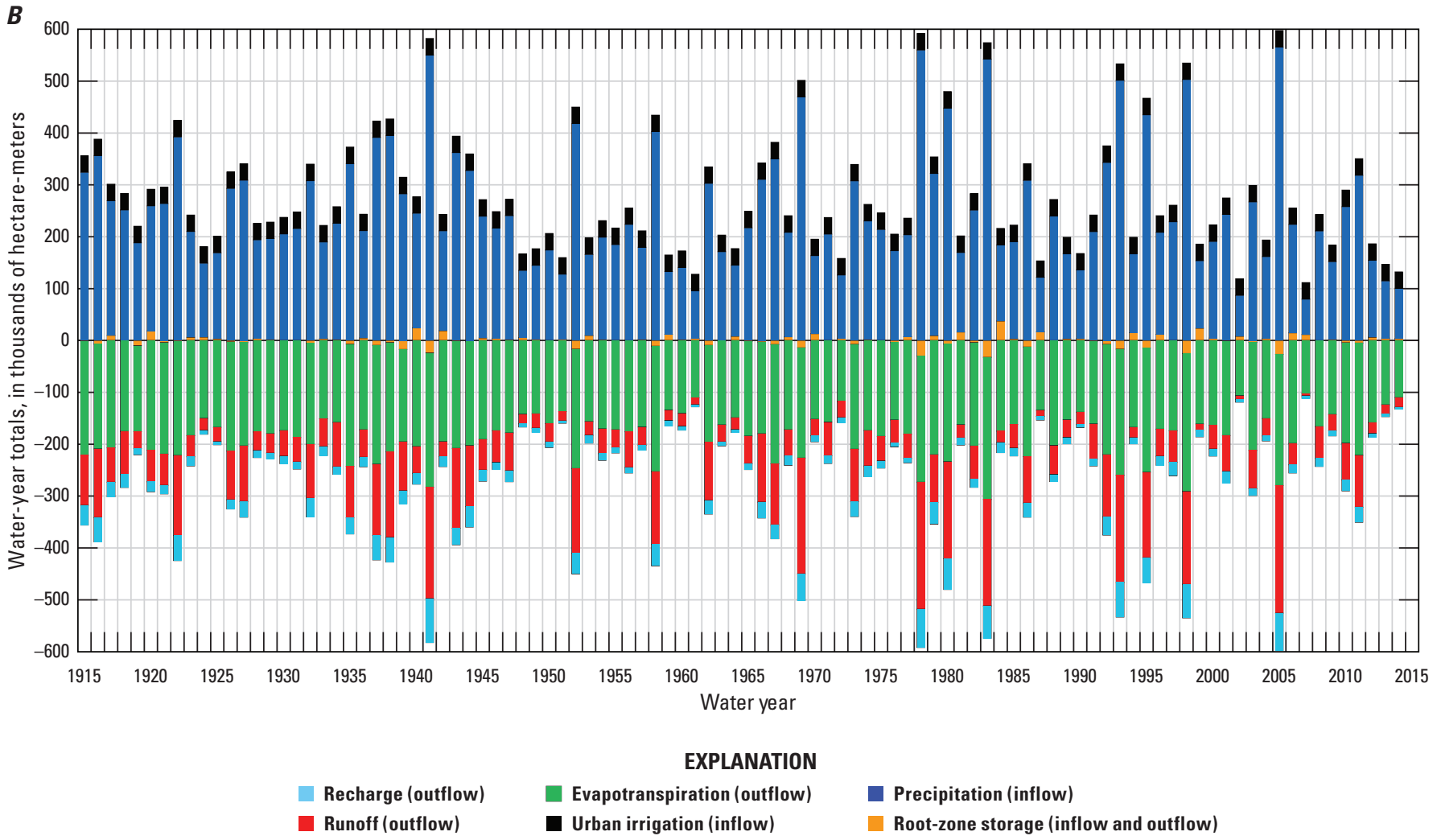

Figure 38. Annual simulation results for water years 1915-2014, Los Angeles Basin watershed model (LABWM), California: A, LABWM water-budget components; $B$, LABWM water-budget components as inflows and outflows; $C$, Los Angeles recharge-study area waterbudget components; $D$, Los Angeles recharge-study area water-budget components as inflows and outflows; $E$, annual recharge for the LABWM domains; $F$, cumulative departure from mean annual recharge for the LABWM domains. 

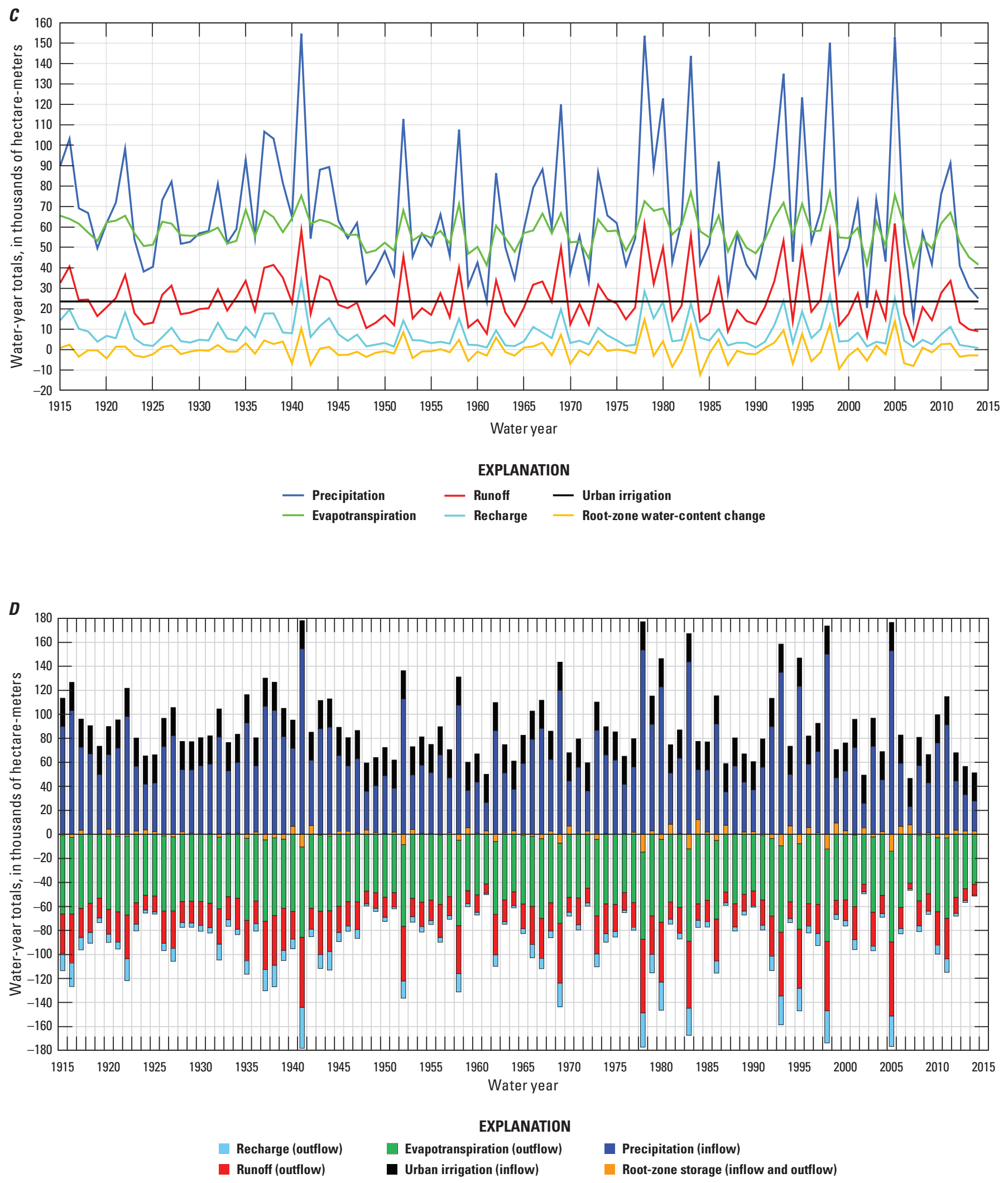

Figure 38. - Continued 
$E$

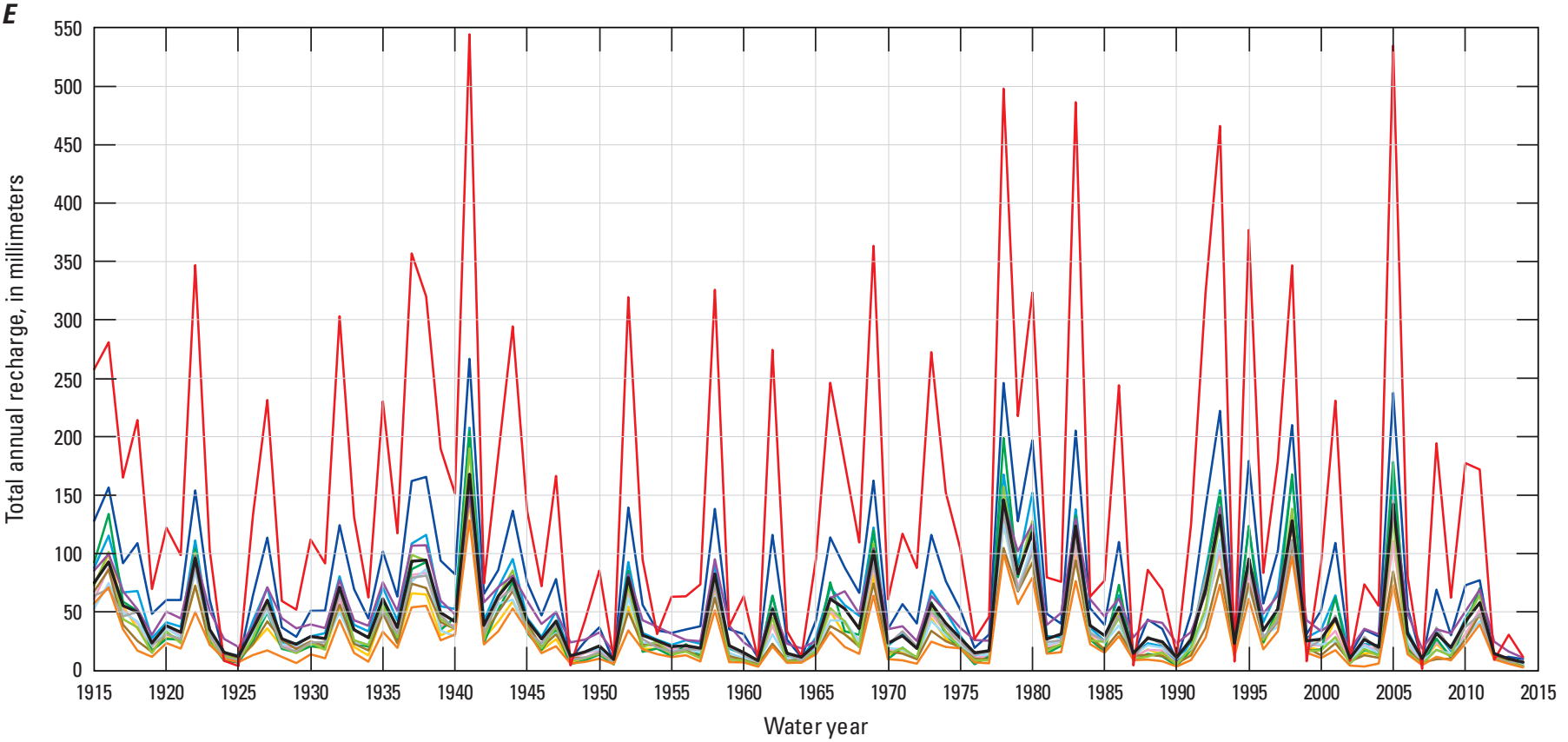

EXPLANATION
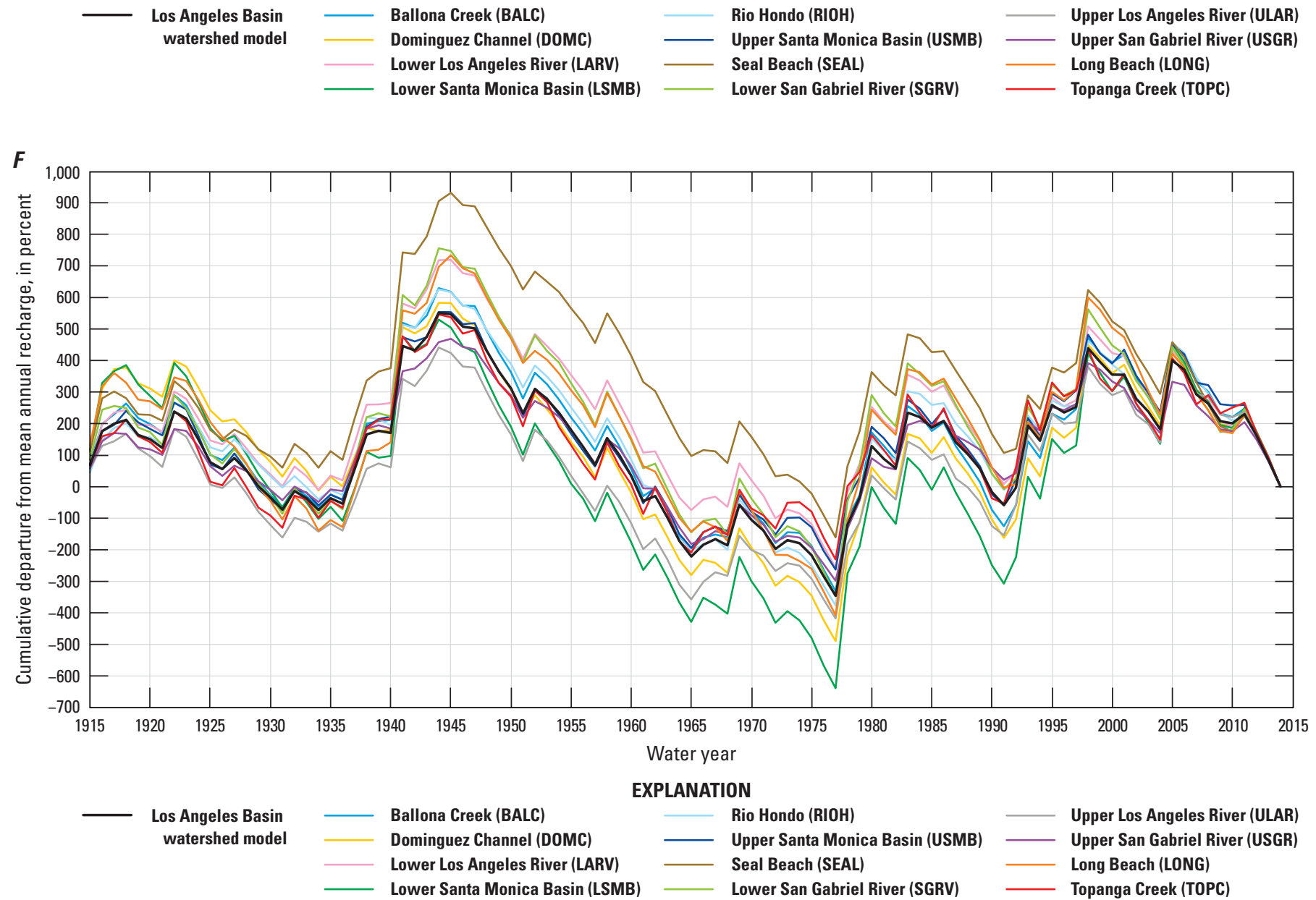

EXPLANATION

Rio Hondo (RIOH) _ Upper Los Angeles River (ULAR)

Upper Santa Monica Basin (USMB) — Upper San Gabriel River (USGR)

Seal Beach (SEAL) _ _ Long Beach (LONG)

Lower San Gabriel River (SGRV) — Topanga Creek (TOPC)

Figure 38. -Continued 
1941, $246 \mathrm{~mm}$ for water year 1978, and $238 \mathrm{~mm}$ for water year 2005. During the driest years, recharge for all subdomains was less than $50 \mathrm{~mm} / \mathrm{yr}$. The cumulative departure from mean annual recharge indicated an initial period of lower than average recharge for all subdomains for water years 1918-36, followed by a period of higher than average recharge for water years 1937-45, and then a long period of generally lower than average recharge for water years 1946-77 (fig. 38F). Water years 1978-83 and 1992-98 were two periods of higher than average recharge for most years, whereas water years 1984-91 and 1998-2014 were two periods of lower than average recharge for most years. The Seal Beach (SEAL) subdomain had the greatest cumulative departure from mean annual precipitation at 932 percent ending with water year 1945, whereas the lower Santa Monica Basin (LSMB) subdomain had the least cumulative departure from mean annual precipitation at -639 percent ending with water year 1977 . For the entire LABWM area, the maximum cumulative departure of 546 percent ended with water year 1944, and the minimum cumulative departure of -346 percent ended with water year 1977.

Annual results for water-budget components for the LAGSA and the eight groundwater basins in the LAGSA are provided in appendix 3 . Annual variability in waterbudget components for the groundwater basins was generally consistent with the results for the entire LAGSA in terms of year-to-year variability and wet or dry periods (figs. 38C, $D$ ). Comparison of results among the groundwater basins, however, also indicated some differences in annual variability in water-budget components. For example, the wettest year for Montebello Forebay was water year 1998 with 878 mm of precipitation, whereas the wettest year for Central Basin Pressure was water year 1978 with $768 \mathrm{~mm}$ of precipitation, and the wettest year for West Coast Basin was water year 2005 with $727 \mathrm{~mm}$ of precipitation (appendix tables 3-1, 3-2, $3-3)$. The driest water year for all three groundwater basins was 2007, with $60 \mathrm{~mm}$ for Montebello Forebay, $75 \mathrm{~mm}$ for Central Basin Pressure, and $77 \mathrm{~mm}$ for West Coast Basin. For the Hollywood groundwater basin, the wettest groundwater basin in terms of average annual precipitation, water year 2005 was the wettest at $942 \mathrm{~mm}$ of precipitation, and water year 2007 was the driest at 91 of mm precipitation (appendix table 3-7). For the Orange County groundwater basin, water year 1941 was the wettest at $748 \mathrm{~mm}$ of precipitation, and water year 2007 also was the driest at $72 \mathrm{~mm}$ of precipitation (appendix table 3-4). Results for simulated annual runoff were similar to results for precipitation, such that differences among groundwater basins in water years with the highest and lowest runoff were closely correlated to differences in precipitation. Results for direct recharge indicated that the water years with the highest and lowest direct recharge for all groundwater basins were consistent; the most direct recharge for all groundwater basins was in water year 1941, and the least direct recharge for all groundwater basins was in water year 2014.

\section{Comparison of Recharge for Wet and Dry Years}

The spatial distribution of recharge for water year 2005, the wettest year in the last decade of the simulation period with basin-wide average recharge of $139 \mathrm{~mm}$, was compared to results for water year 2007, the driest year in the simulation period with basin-wide average recharge of $6 \mathrm{~mm}$ (fig. 39). The maximum recharge for water year 2005 was 3,786 mm (fig. 39A), compared to a maximum recharge of only $297 \mathrm{~mm}$ for water year 2007 (fig. 39B). For the relatively wet water year (2005), recharge of $210 \mathrm{~mm}$ and greater was simulated for many upland areas underlain by bedrock with intermediate to high permeability. For upland areas with low permeability bedrock, such as along the northern boundary of the LABWM area in the San Gabriel Mountains, recharge was mostly limited to about $2-10 \mathrm{~mm}$ and was about the same as the recharge simulated for the dry year 2007. For the dry water year (2007), recharge for much of the San Gabriel Mountains was reduced from high values of more than $210 \mathrm{~mm}$ in water year 2005 to about 11-50 mm. Recharge for much of the Santa Monica Mountains was reduced from high values of more than $210 \mathrm{~mm}$ for wet water year (2005) to values of $10 \mathrm{~mm}$ and less. During the dry water year (2007), the increased recharge from urban irrigation was a larger component of overall recharge in the lowland areas compared to results for the wet water year (2005).

\section{Average Monthly Results}

Average monthly results were calculated as basin-wide averages for the LABWM to analyze the seasonal distribution of selected water-budget components. The highest average monthly precipitation of 59,000 ha-m was during February, and the lowest average monthly precipitation of about zero was in July (fig. 40A). The maximum average monthly ET of about 28,000 ha-m was attained in April, and the maximum streamflow of about 24,000 ha-m was in February (fig. 40A). Average monthly recharge did not show a correlation to average monthly urban irrigation (fig. 40B), indicating that the timing of recharge was more dependent on precipitation than on urban irrigation. The maximum average monthly recharge of about 4,700 ha-m was during March the last month of the quarter that had the minimum urban irrigation rate of 750 ha-m.

The distribution of average monthly inflows and outflows shows the approximate water budget (changes in root-zone storage are excluded) and the relative magnitudes of the various water-budget components. Precipitation was the dominant inflow from October through May, but urban irrigation was the dominant inflow from June through September (fig. 40C). Streamflow was the dominant outflow from December through February, whereas ET was the dominant outflow from March through November. Streamflow discharge from the LABWM was zero for the months of May through August, but recharge was 1,000 ha-m or more for these months. 


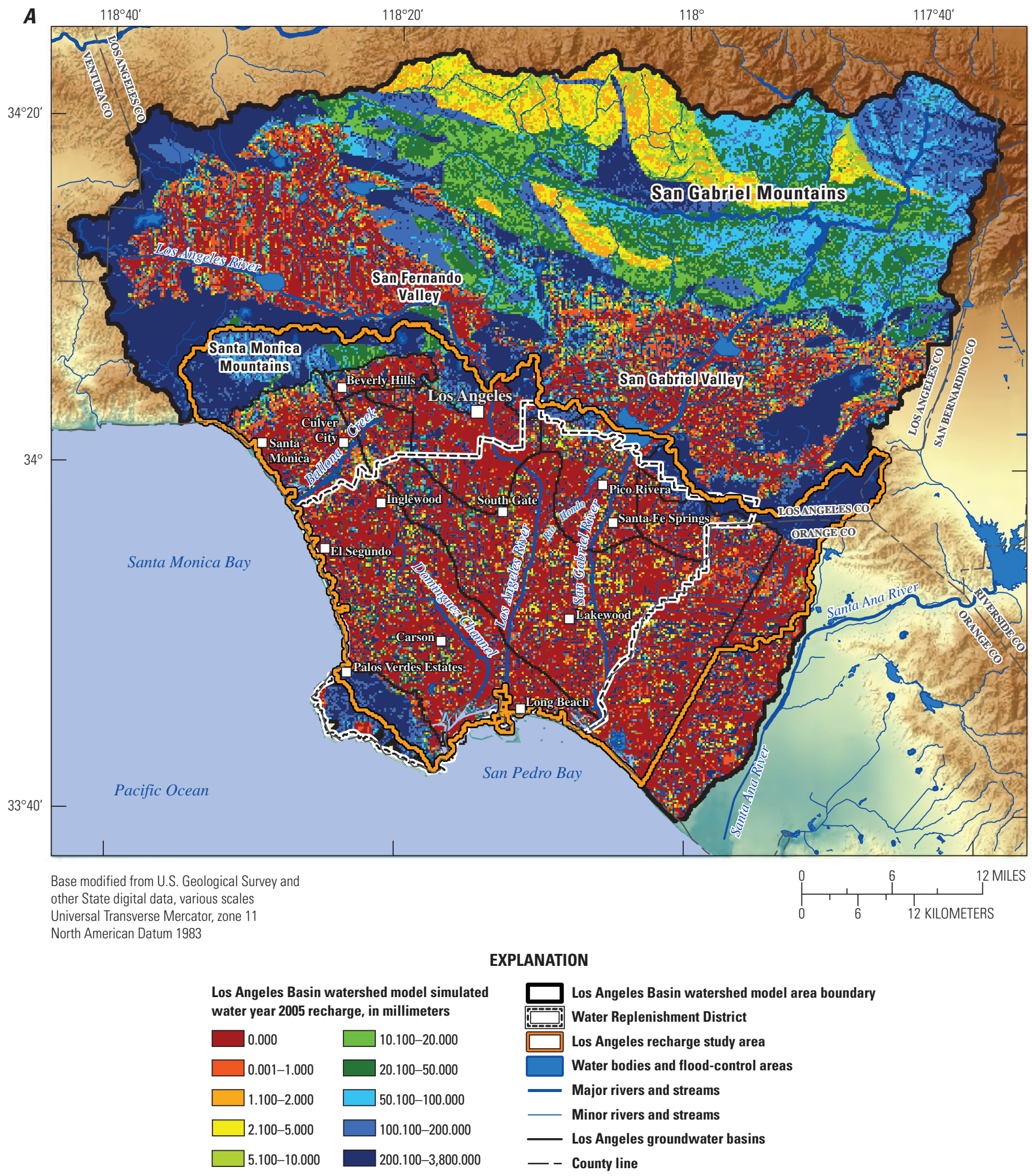

Figure 39. Simulated annual recharge, Los Angeles basin watershed model (LABWM), California, for $A$, water year 2005; and $B$, water year 2007. 


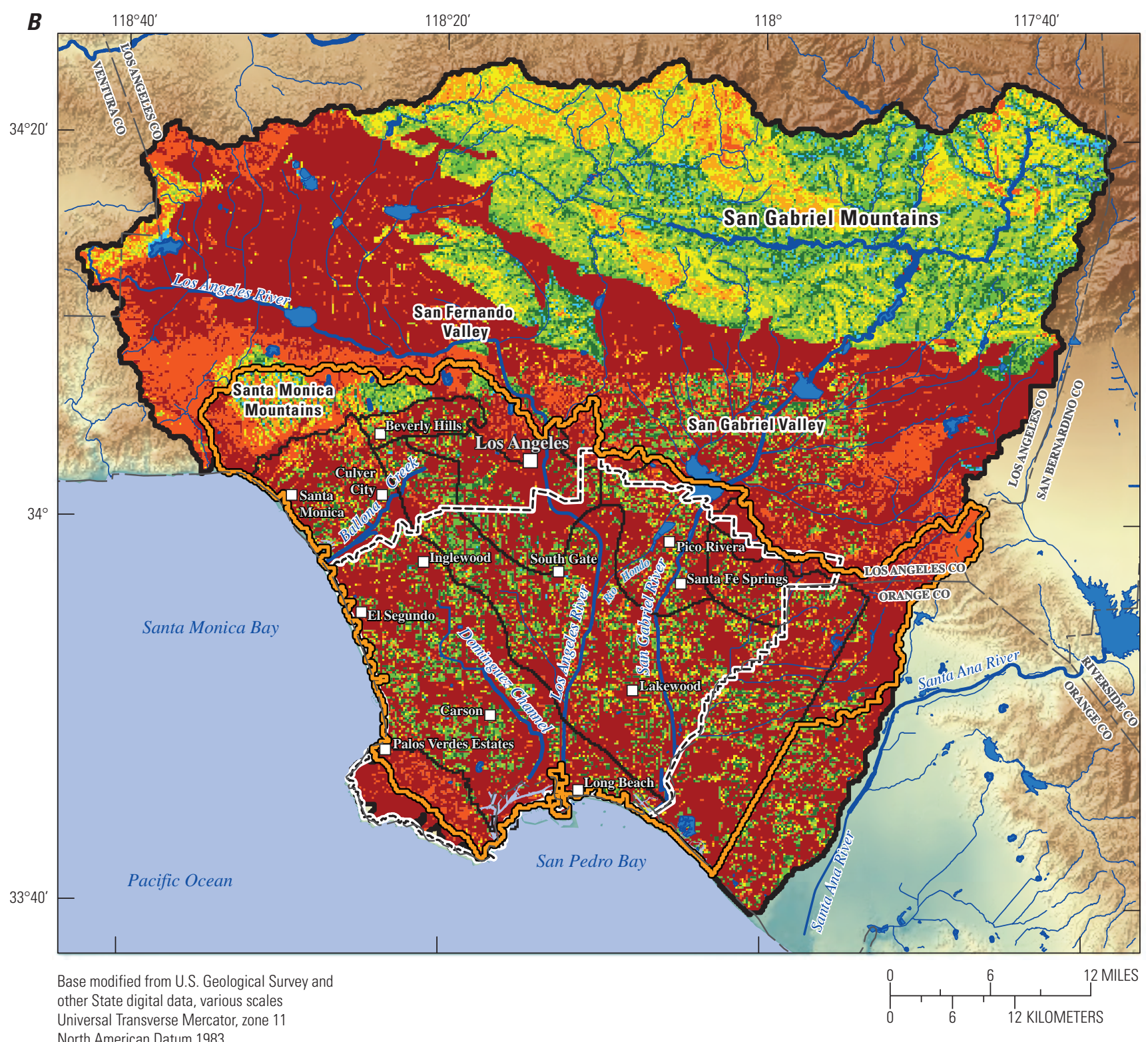

North American Datum 1983

\section{EXPLANATION}

Los Angeles Basin watershed model simulated water year 2007 recharge, in millimeters

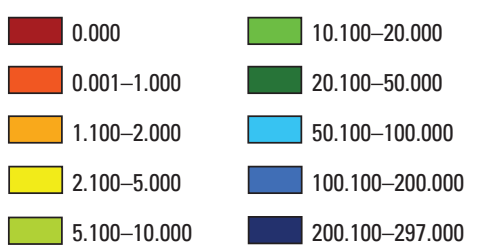

Los Angeles Basin watershed model area boundary

Water Replenishment District

Los Angeles recharge study area

Water bodies and flood-control areas

Major rivers and streams

Minor rivers and streams

— Los Angeles groundwater basins

- County line

Figure 39. - Continued 
$\boldsymbol{A}$

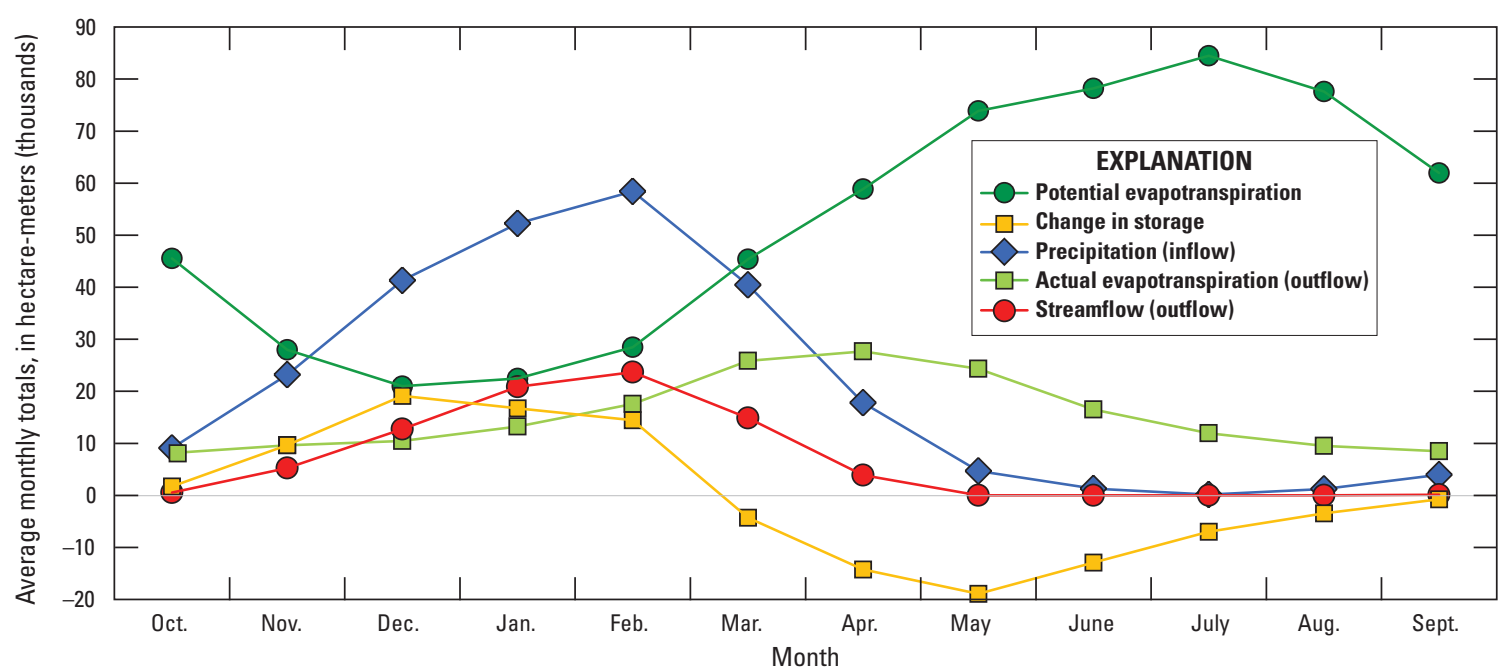

B


Figure 40. Average basin-wide monthly simulation results for water years 1915-2014, Los Angeles Basin watershed model (LABWM), California: $A$, water-budget components; $B$, urban irrigation and recharge; $C$, inflows and outflows. 


\section{Recharge Estimates Developed for the LAGSA}

The LABWM was primarily developed to estimate recharge for the LAGSA, which is the general area of interest for groundwater resources in the region. By using the LABWM simulation results, monthly and quarterly recharge were calculated for the areas of the LAGSA and six bordering drainages upstream from and tributary to the LAGSA that were included in the Los Angeles recharge-study area (fig. 41). The tributary drainages that were included in the Los Angeles recharge-study area contribute surface-water inflows, including overland runoff and seepage flow, to the LAGSA. Although the effect of the surface-water inflows on increasing direct recharge within the LAGSA is represented in the INFILv3 simulation, additional recharge from the tributary drainages could also contribute to the total recharge for the LAGSA as a mountain-front recharge component, and this was not directly represented by the INFILv3 simulation. In order to improve estimates of the total potential recharge to the LAGSA, the monthly and quarterly mountain-front recharge components along the LAGSA boundary were calculated and added to the direct recharge in the LAGSA. This method of developing estimates of total potential recharge for the LAGSA using the combined direct and mountain front recharge components is similar to methods used in Reichard and others (2006) for estimating total recharge.

Similar to the annual recharge results for the LABWM area, the total, direct, and mountain-front annual recharge results for the LAGSA indicated a high degree of year-toyear variability (fig. 42A). A maximum annual total recharge of 34,000 ha-m was simulated for water year 1941, of which the mountain-front recharge component contributed about 12,000 ha-m, and direct recharge in the LAGSA contributed about 22,000 ha-m. A minimum total annual recharge of 781 ha-m was simulated for water year 2014, of which mountain-front recharge was 194 ha-m. The 100-year average total potential recharge rate for the LAGSA was about 7,900 ha-m/yr, of which about 2,700 ha-m/yr was mountainfront recharge, and 5,200 ha-m/yr was direct recharge $n$ the LAGSA.

To identify wet and dry periods in terms of multiyear averaged recharge estimates, the 5-year movingaverage recharge was calculated for the LAGSA, the eight groundwater basins in the LAGSA, and the six bordering mountain-front areas that potentially contribute recharge to the LAGSA. The wettest 5-year period ended with water year 1941 and had an average of about 75 mm/yr of direct recharge for the LAGSA (fig. 42B). The 5-year periods ending with water year 1982 and 1999 also had higher than average direct recharge in the LAGSA of more than $50 \mathrm{~mm} / \mathrm{yr}$. The 5-year average recharge for all eight groundwater basins were similar; water years 1937-41 had the highest 5-year average recharge rate for all groundwater basins, and water years 1987-91 had the lowest 5-year average recharge rate for all but the Orange County groundwater basin, which had the lowest 5-year average recharge rate for water years 1960-64. The Montebello Forebay Basin consistently had the highest 5-year average recharge, and the Orange County Basin consistently had the lowest 5-year average recharge. For all basins, the 5-year average recharge rate followed a pattern of high values for the 5-year periods ending with water years 1939-45, water years 1980-84, and water years 1995-2001. Similarly, all groundwater basins followed a pattern of low 5-year average recharge rates for periods ending with water years 1948-67, 1974-77, 1988-92, 2002-03, and 2010-14.

For most periods, the 5-year average recharge for all six of the tributary mountain-front areas bordering the LAGSA was greater than the direct recharge for the LAGSA (fig. 42C). The Palo Verdes Hills had less average recharge than the LAGSA for a few of the drier periods, such as water years 1927-31, 1949-51, 1957, and 1991. The Santa Monica Mountains had the highest 5-year average recharge for all water years except 1980, when the Puente Hills had a higher recharge rate. The 100-year average recharge was $94 \mathrm{~mm} / \mathrm{yr}$ for the Santa Monica Mountains, $52 \mathrm{~mm} / \mathrm{yr}$ for the Elysian Hills, $62 \mathrm{~mm} / \mathrm{yr}$ for the Repetto Hills, $66 \mathrm{~mm} / \mathrm{yr}$ for the Puente Hills, 52 mm/yr for the Brea and Fullerton Creeks, and $51 \mathrm{~mm} / \mathrm{yr}$ for the Palo Verdes Hills, compared to a 100-year average recharge of $35 \mathrm{~mm} / \mathrm{yr}$ for the LAGSA.

The average monthly recharge was highest during March for all six mountain-front areas contributing recharge to the LAGSA (fig. 42D). The Santa Monica Mountains and the Puente Hills peripheral drainages had the highest average monthly recharge rate at about $20 \mathrm{~mm}$. From January through July, the recharge rate for all peripheral drainages exceeded the internal-area recharge rate for the LAGSA. From August through November, however, the internal-area recharge exceeded the recharge rate for five of the six upstream peripheral drainages because of increased recharge from urban irrigation in the internal area.

\section{Effect of Urban Irrigation on Recharge}

Simulation results with and without urban irrigation were compared for the eight LABWM subdomains containing the area of the LAGSA and the mountain-front recharge areas in the Los Angeles recharge-study area (table 13). The comparison was done for simulated ET, change in root-zone water storage, recharge, and runoff. For the total area of the subdomains, the results showed a 51 percent increase in ET from urban irrigation, with 82 percent of the irrigation inflow contributing to ET (table 13). The Long Beach subdomain had the largest increase in ET from urban irrigation (62 percent), and the upper Santa Monica basin subdomain had the largest percentage of urban irrigation contributing to ET (69 percent). Urban irrigation resulted in a 247 percent decrease in the change in root-zone water storage for the total area of the eight subdomains, with a change in water storage of -211 ha-m/yr with urban irrigation compared to a change in water storage of -61 ha-m/yr without urban irrigation. 


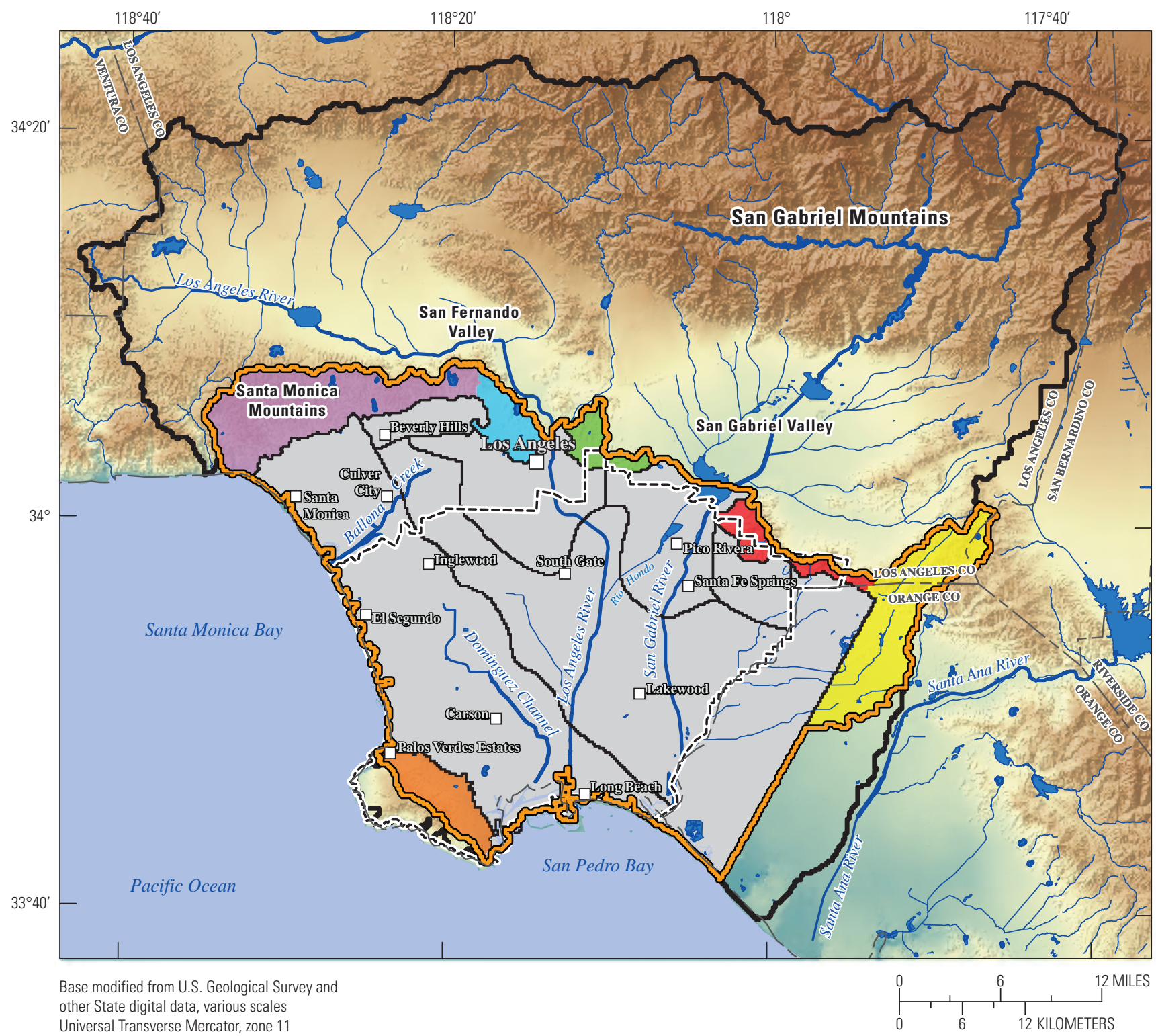

Universal Transvers

North American Datum 1983

\section{EXPLANATION}

Recharge areas for the Los Angeles groundwater study area

$\square$ Internal recharge area

Contributing subdrainages

$\square$ Brea and Fullerton Creeks

Elysian Hills

Palos Verdes Hills

Puente Hills

Repetto Hills

Santa Monica Mountains

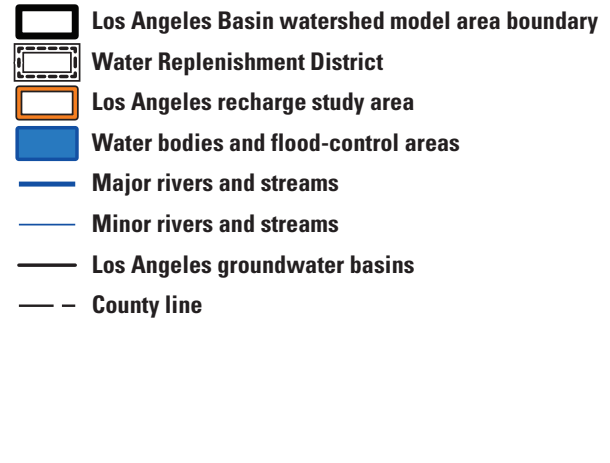

Figure 41. Recharge areas for the Los Angeles groundwater study area, Los Angeles Basin watershed model (LABWM), California. 


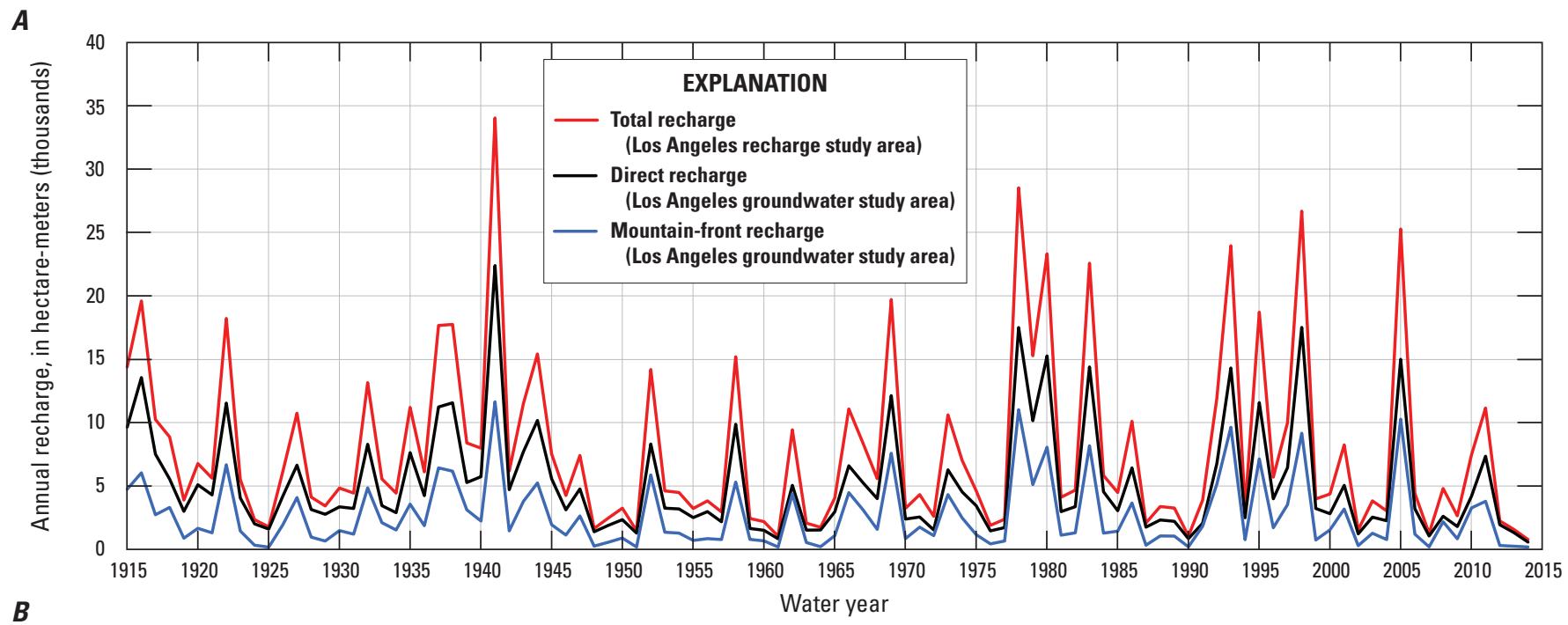

B
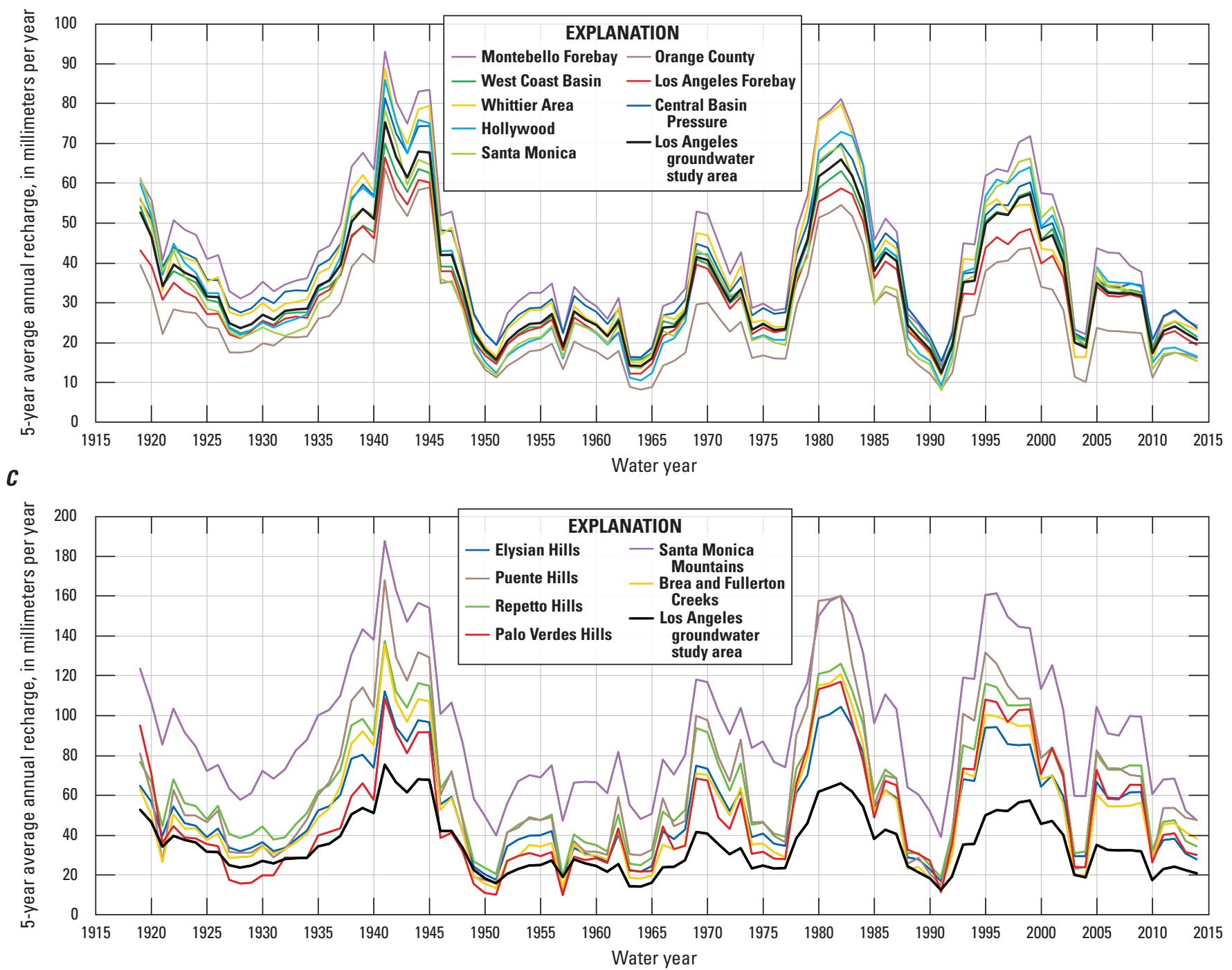

Figure 42. Annual and average monthly recharge simulated for the Los Angeles groundwater study area, Los Angeles Basin watershed model (LABWM), California: $A$, direct and mountain-front recharge components; $B, 5$-year average annual direct recharge for groundwater basins; $C, 5$-year average annual recharge for mountain-front areas; $D$, average monthly recharge rate. 


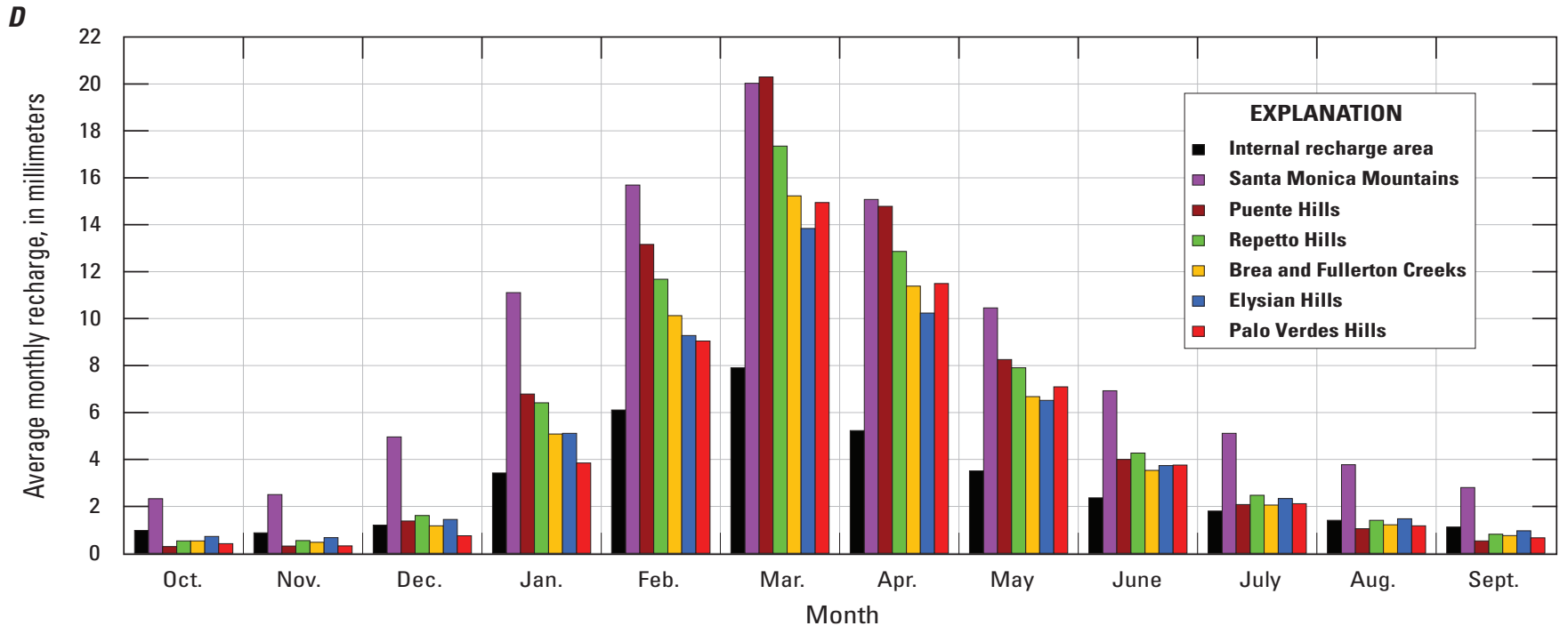

Figure 42. - Continued 


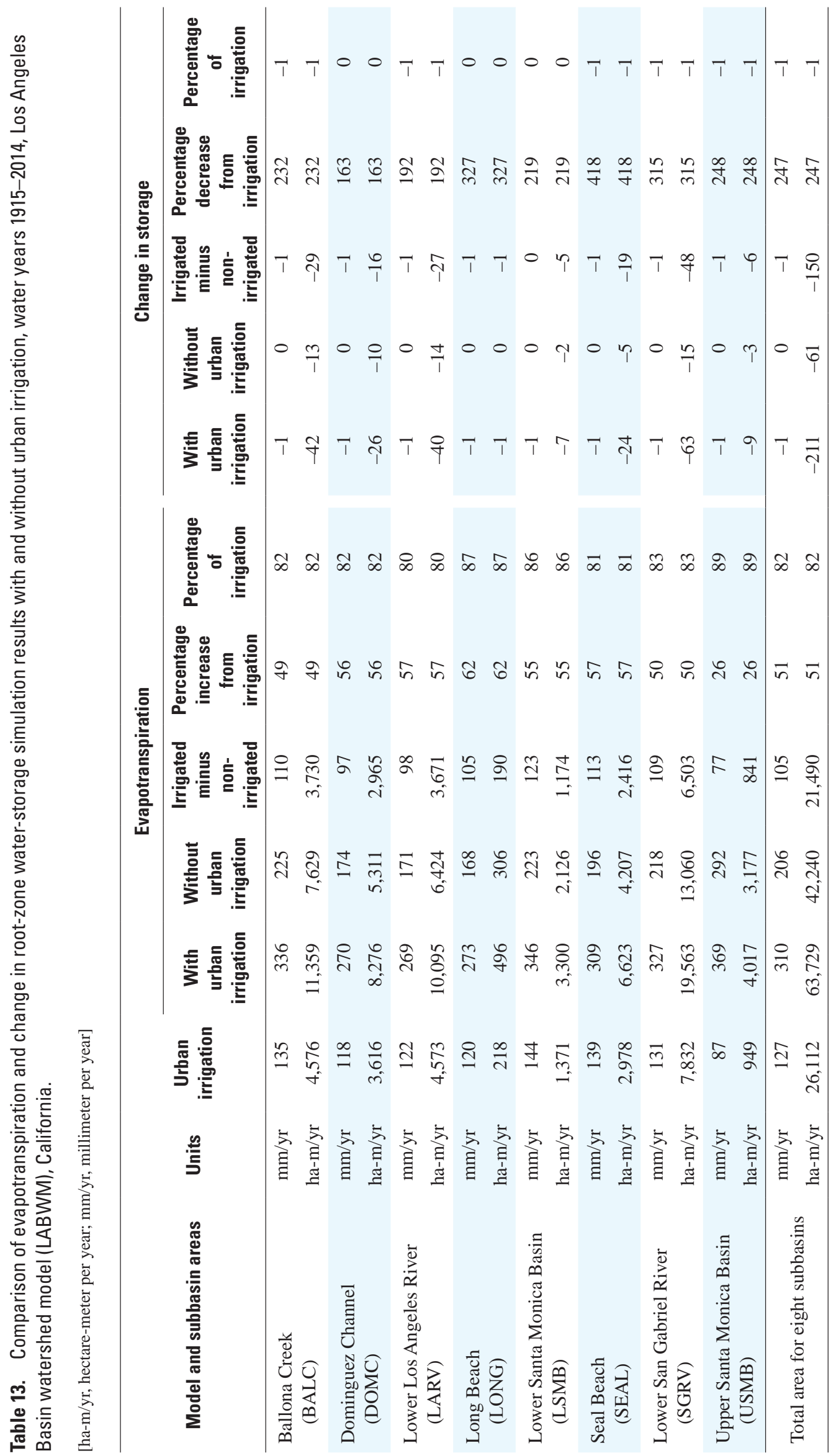


The comparison of recharge results for the eight subdomains indicated an approximate doubling of the average recharge rate for water years 1915-2014 when urban irrigation was included in the model, with an average recharge of $8,473 \mathrm{ha}-\mathrm{m} / \mathrm{yr}$ including urban irrigation compared to an average recharge of 3,741 ha-m/yr without including urban irrigation (table 14). About 18 percent of urban irrigation contributed to recharge, varying from 12 percent for the upper Santa Monica basin subdomain to 20 percent for the lower Los Angeles River subdomain. For the total area of the eight subdomains, the irrigation-induced recharge provided an average return flow of 4,733 ha-m/yr. In contrast to recharge, the effect of urban irrigation on streamflow was slight; it increased only $48 \mathrm{ha}-\mathrm{m} / \mathrm{yr}$ from urban irrigation for the total area of the eight subdomains, which was only 0.2 percent of urban irrigation.

Simulations with and without urban irrigation were compared to evaluate the effect of urban irrigation on the spatial distribution of ET, the change in root-zone water content, streamflow, and recharge in the Los Angeles rechargestudy area. Results for simulated ET without urban irrigation indicated a large reduction in ET in the Los Angeles rechargestudy area (fig. 43). Rates of ET showed maximum reductions of 321 to $412 \mathrm{~mm}$ where the most urban irrigation was used (fig. 43). The rate of ET was reduced more than $40 \mathrm{~mm} / \mathrm{yr}$ in most of the Los Angeles recharge-study area.

Results for the change in root-zone storage using the simulation without urban irrigation indicated a drier root zone compared to results with urban irrigation (fig. 44). The areas where root-zone storage increased were greatly reduced without irrigation. The difference between irrigated and non-irrigated changes in the root-zone water content was the greatest for the more pervious locations that received surfacewater run-on in addition to urban irrigation, with differences of $4 \mathrm{~mm} / \mathrm{yr}$ and greater (fig. 44 ).

The difference between simulated streamflow with urban irrigation and simulated streamflow without it indicated an increase in runoff caused by urban irrigation (fig. 45). In the area of the Los Angeles recharge-study area, runoff from irrigation increased primarily in the upland areas of the peripheral drainages, where the soils are thinner and the storage capacity of the root zone is less than in the lowland areas with thick alluvium. In the lowland areas, urban irrigation caused only a very slight increase in runoff. The larger stream channels draining the upland areas, however, showed a greater increase in streamflow, and the maximum difference in streamflow was in the most upstream portions of the main channels.

The difference between simulated recharge with urban irrigation and simulated recharge without urban irrigation indicated increases in recharge in response to urban irrigation by as much as 201 to $452 \mathrm{~mm} / \mathrm{yr}$ in areas with inflows from surface-water run-on (fig. 46).

Average monthly recharge simulated without including urban irrigation was compared to simulation results that included urban irrigation (figs. 42D, 47A, B, C). The monthly distribution of recharge for the internal recharge area of the LAGSA and the six peripheral drainage areas contributing mountain-front recharge to the LAGSA were similar for the with and without irrigation results, but showed the expected overall decrease in recharge for all months when irrigation was not included (fig. 47B). The greatest absolute difference in the average monthly recharge showed the greatest absolute difference, about $5.25 \mathrm{~mm}$, during March in the internal recharge area (fig. 47B). In general, the absolute increase in recharge for all areas was greatest during the months of January through May, indicating that the largest increases in recharge were caused by an increase in net infiltration from run-on with wet antecedent soil conditions when urban irrigation was included. The largest relative increases in average monthly recharge for irrigated minus non-irrigated simulation results were for the months of July through January (fig. 47C). The greater recharge in the summer months was caused directly by the net infiltration of urban irrigation. The greater recharge during December and January, however, was caused by the wet antecedent soils enhancing recharge from precipitation and run-on components. The largest relative increase in recharge from urban irrigation was in the internal recharge area of the LAGSA, which had increases of more than 1,000 percent for September through November and increases of more than 100 percent for all other months. In contrast, the relative increases in recharge for the Santa Monica Mountains contributing area was less than 10 percent for all months.

To qualitatively evaluate the sensitivity of simulated recharge and ET to the urban-irrigation estimates, simulation results for water years 1928-2011 for the eight subdomains overlying the Los Angeles recharge-study area (area contributing recharge to the LAGSA) were compared for a range of urban irrigation estimates that were calculated by a simple scaling of the urban irrigation rates using a linear multiplier. A multiplier of 1.0 was used to identify the results obtained for the calibrated model, referred to in this analysis as the baseline result. The minimum multiplier was 0 (no urban irrigation), and the maximum multiplier was 2.0 (for a doubling of the urban irrigation rates used in the baseline simulation). Simulated 1928-2011 average recharge and ET were the most affected by variations in urban irrigation. For most subdomains, recharge approximately doubled with a corresponding doubling of irrigation relative to the base case (fig. 48A), and ET increased by more than 25 percent for most subdomains (fig. 48B). The maximum recharge rate was simulated for the upper Santa Monica Basin (USMB) subdomain, where recharge of about $79 \mathrm{~mm} / \mathrm{yr}$ in the baseline simulation increased to about $111 \mathrm{~mm} / \mathrm{yr}$ when urban irrigation was doubled (fig. 48A). The Seal Beach (SEAL) subdomain had the greatest sensitivity of recharge to urban irrigation. Without urban irrigation (irrigation multiplier set to 0), Seal Beach (SEAL) had the lowest recharge rate at about $5 \mathrm{~mm} / \mathrm{yr}$. As the irrigation rate was increased to double the baseline rate, however, the Seal Beach (SEAL) recharge rate increased to about $80 \mathrm{~mm} / \mathrm{yr}$ (about a 16-fold increase in recharge). 


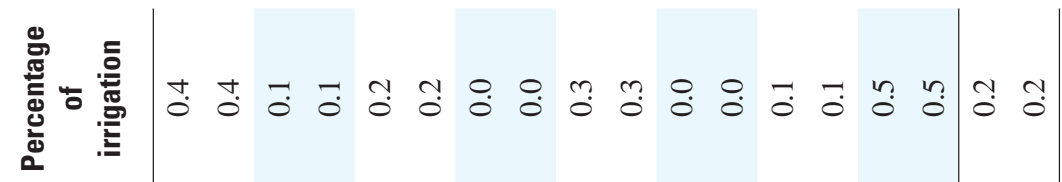

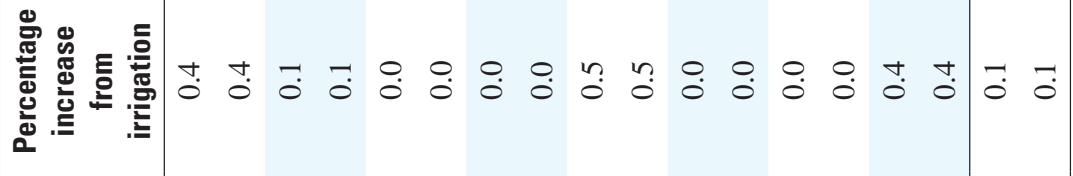

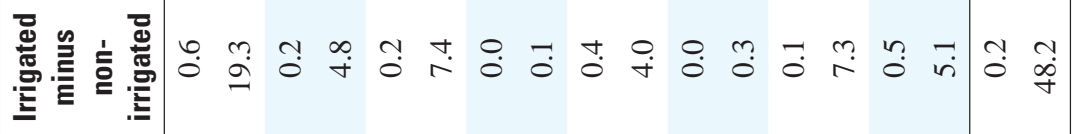

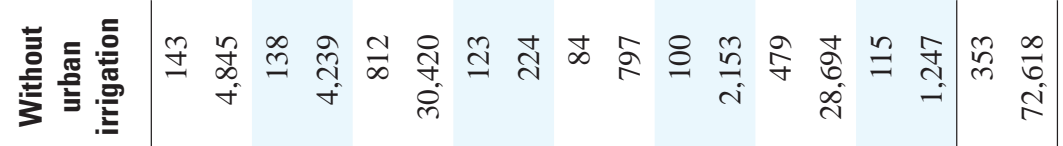

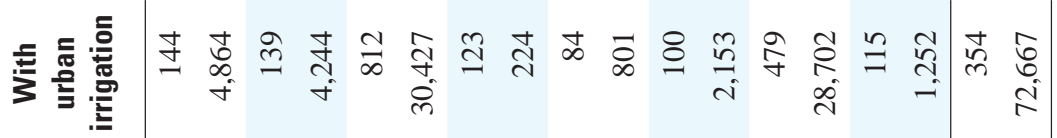

$$
\begin{aligned}
& \text { 咅 }
\end{aligned}
$$

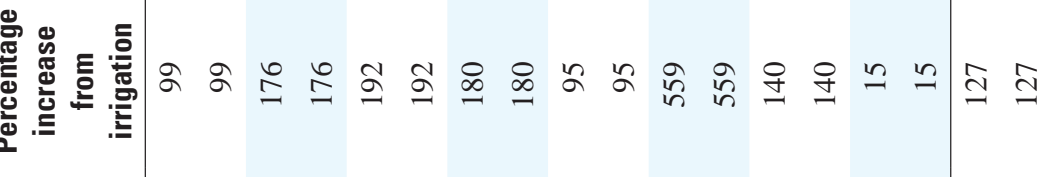

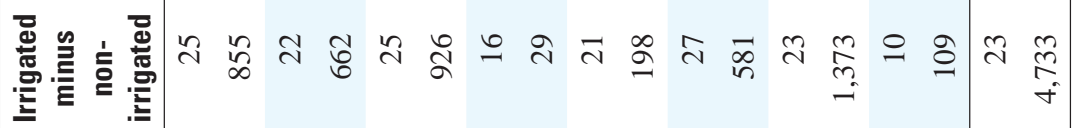

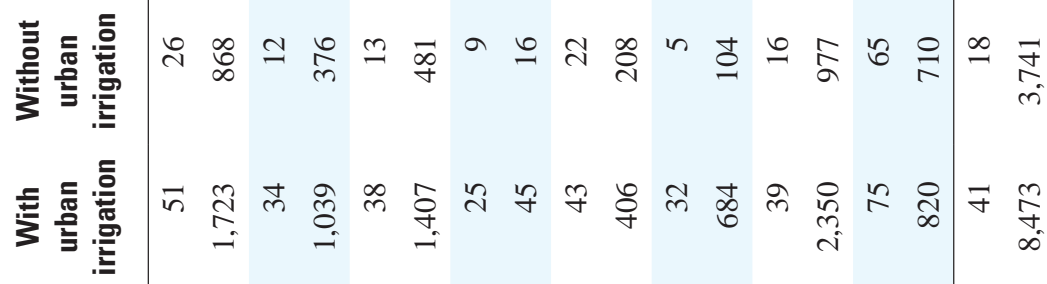

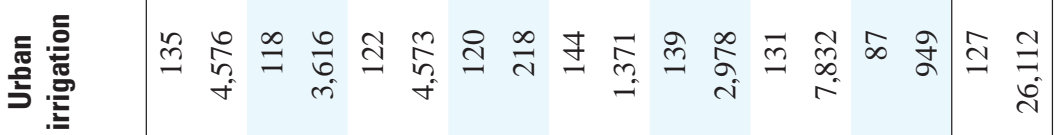

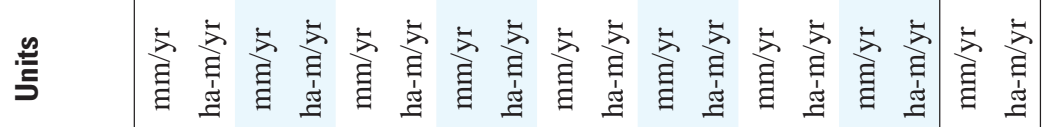

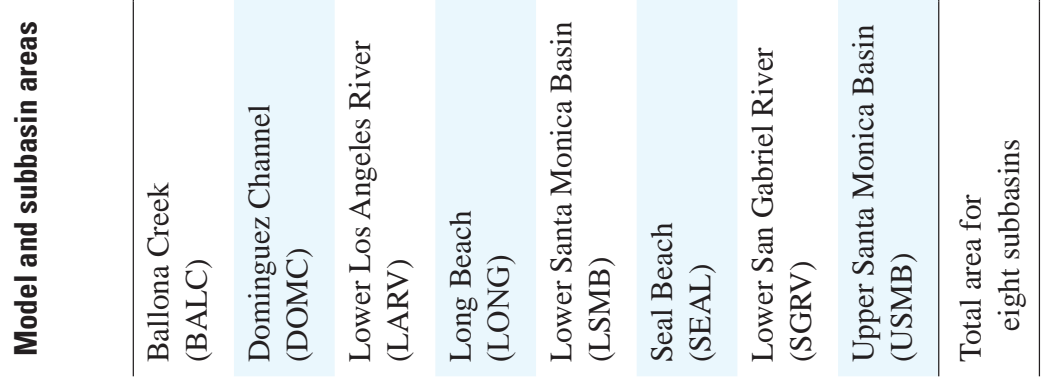




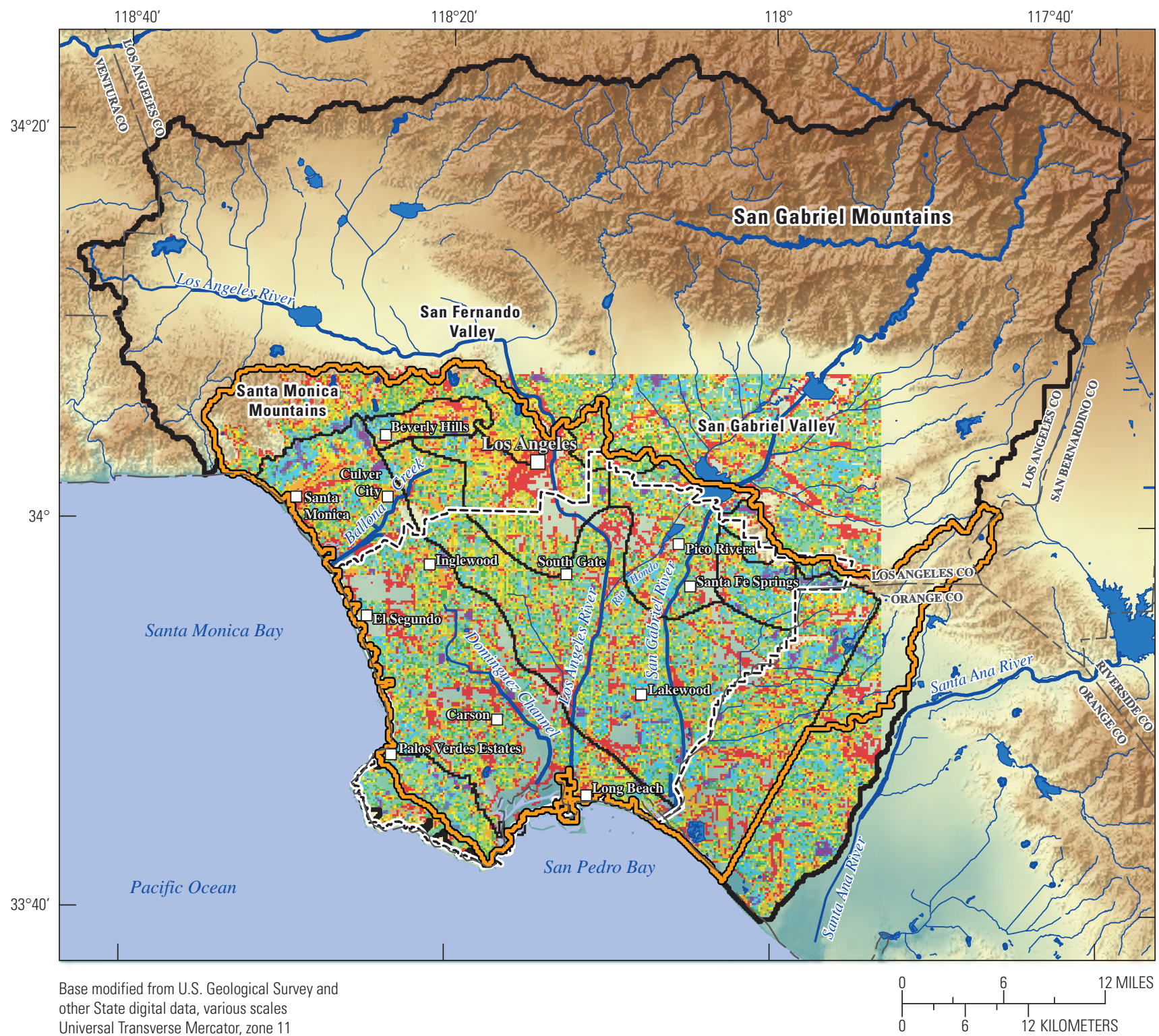

Universal Transverse Mercator, zone 11

North American Datum 1983

\section{EXPLANATION}

Simulated 1915-2014 evapotranspiration difference, irrigated minus non-irrigated, in millimeters per year

\begin{tabular}{|c|c|}
\hline $1-40$ & $161-200$ \\
\hline $41-80$ & $201-240$ \\
\hline $81-120$ & $241-280$ \\
\hline $121-160$ & $281-320$ \\
\hline
\end{tabular}

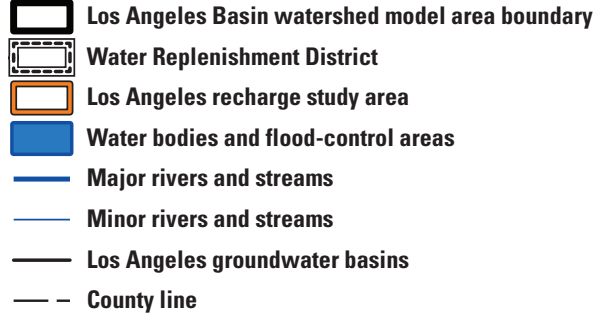

Figure 43. Difference in simulation results, irrigated minus non-irrigated evapotranspiration for the Los Angeles recharge-study area, water years 1915-2014, Los Angeles Basin watershed model (LABWM), California. 


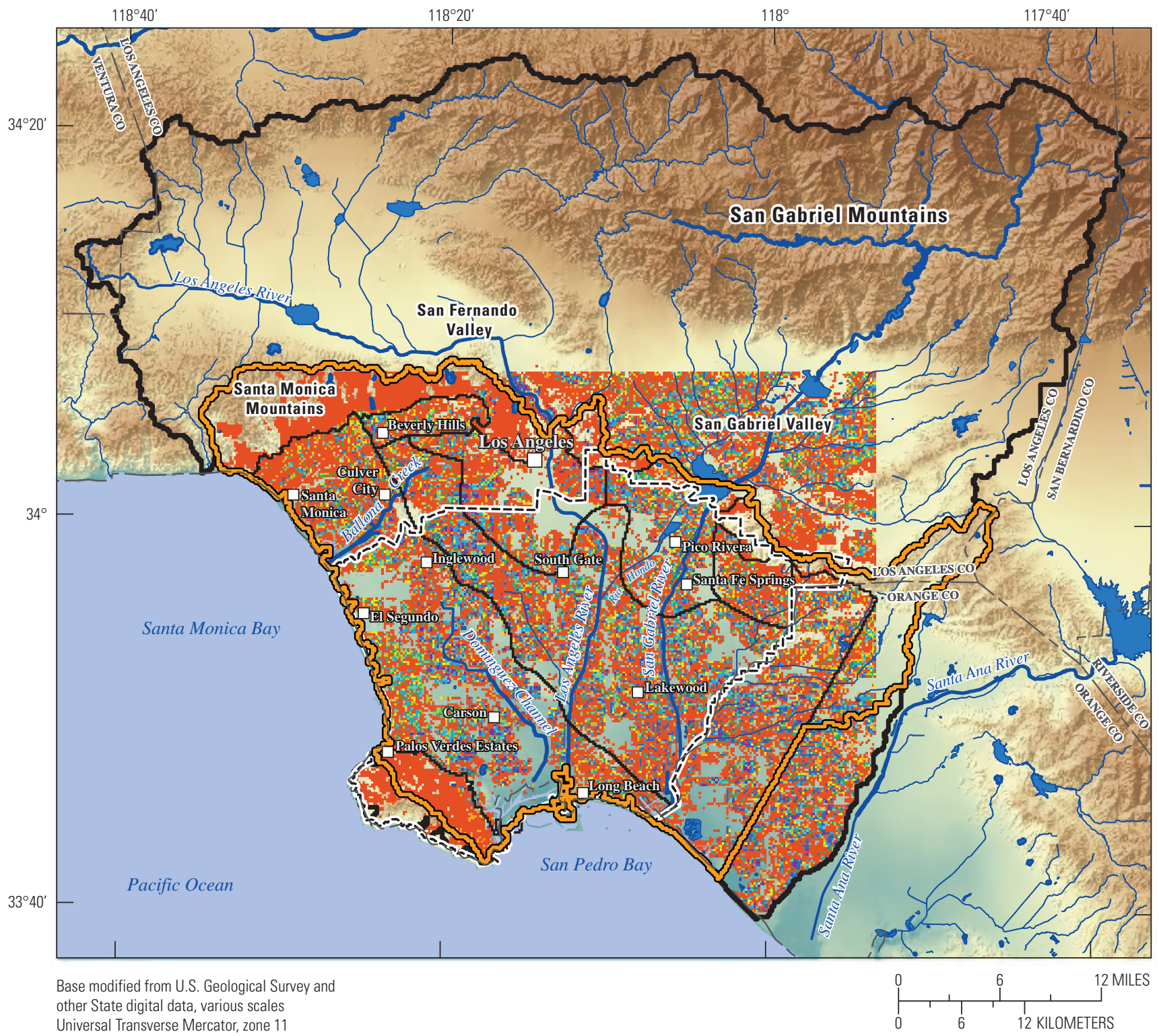

Universal Transverse Mercator, zone 11 North American Datum 1983

\section{EXPLANATION}

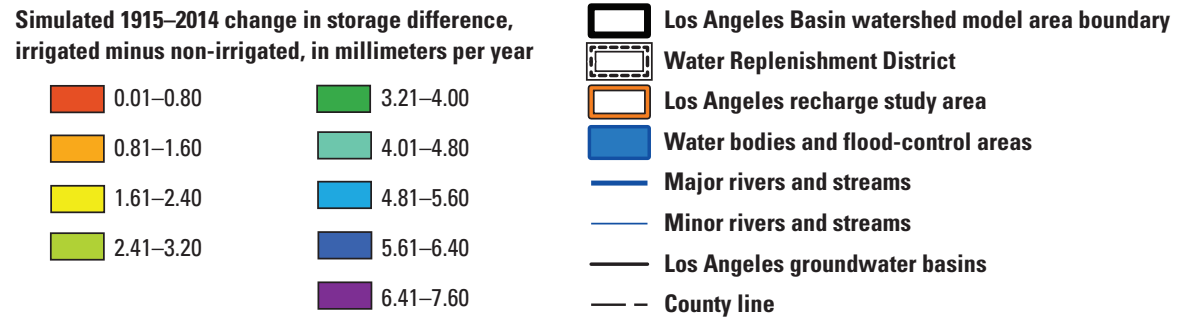

Figure 44. Difference in simulation results, irrigated minus non-irrigated change in root-zone storage for the Los Angeles rechargestudy area, water years 1915-2014, Los Angeles Basin watershed model, California. 


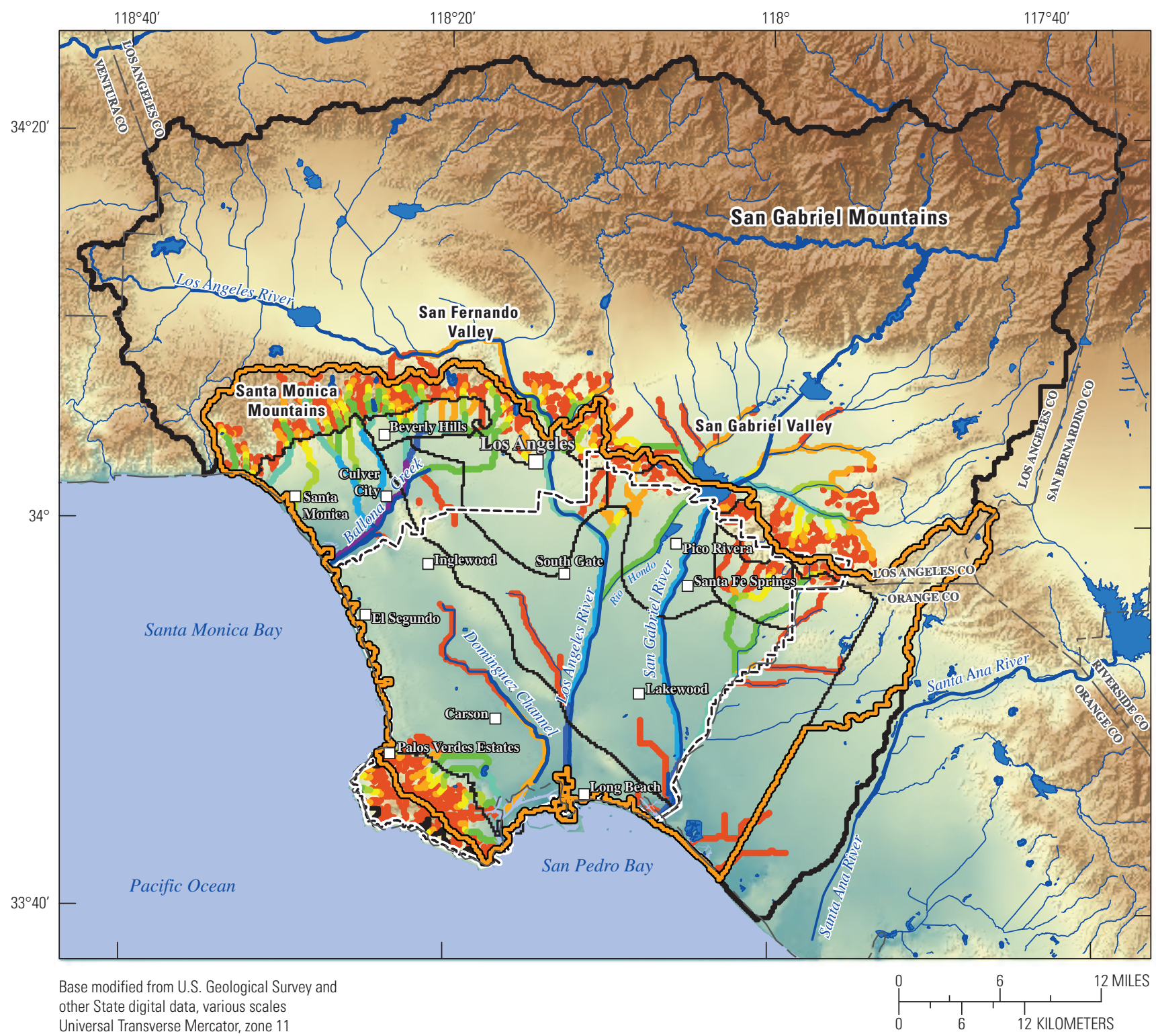

North American Datum 1983

EXPLANATION

Simulated 1915-2014 streamflow difference, irrigated minus non-irrigated, in cubic-meters per day

$\begin{array}{lll}1-5 & 16-20 & 101-150 \\ 6-10 & 21-50 & 151-200 \\ 11-15 & 51-100 & 201-543\end{array}$

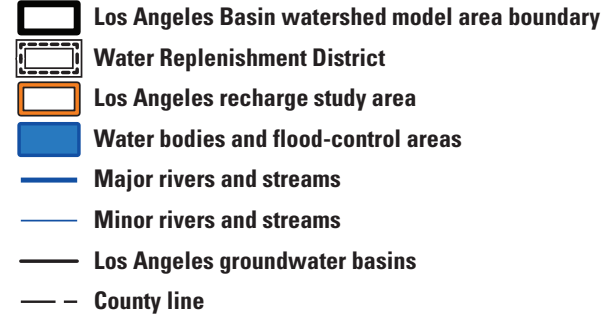

Figure 45. Percentage difference for irrigated minus non-irrigated simulation simulated runoff for the Los Angeles recharge-study area, water years 1915-2014, Los Angeles Basin watershed model (LABWM), California. 


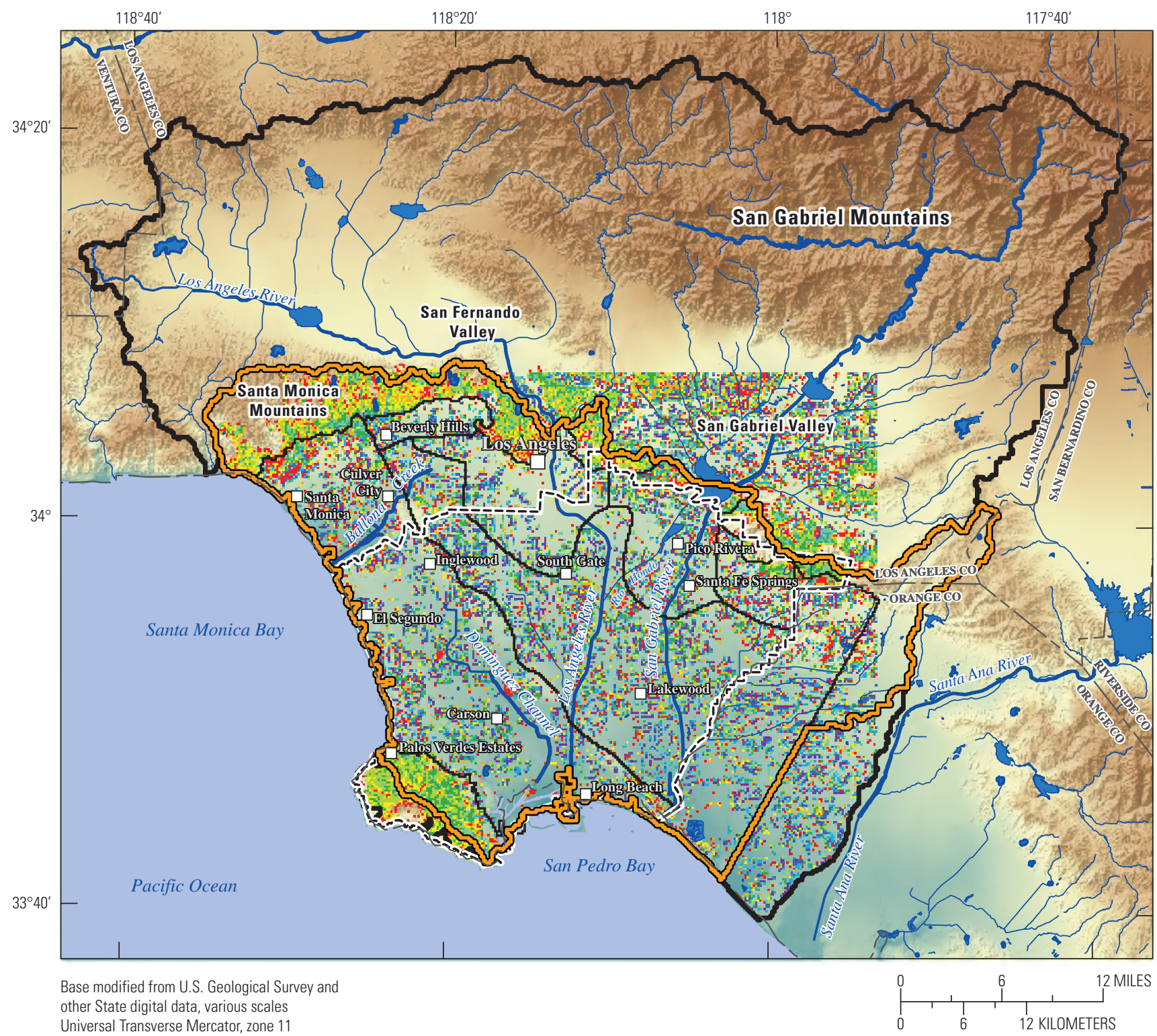

Universal Transverse Mercator, zone 11 North American Datum 1983

\section{EXPLANATION}

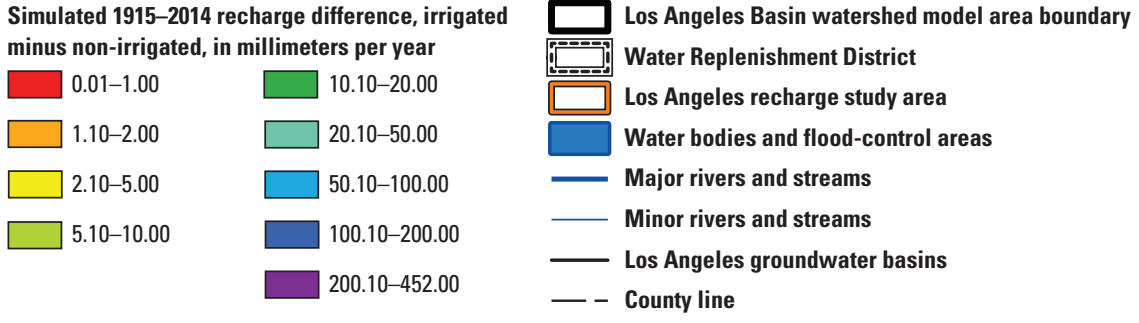

Figure 46. Difference in results, irrigated minus non-irrigated simulated recharge for the Los Angeles recharge-study area, water years 1914-2015, Los Angeles Basin watershed model (LABWM), California. 

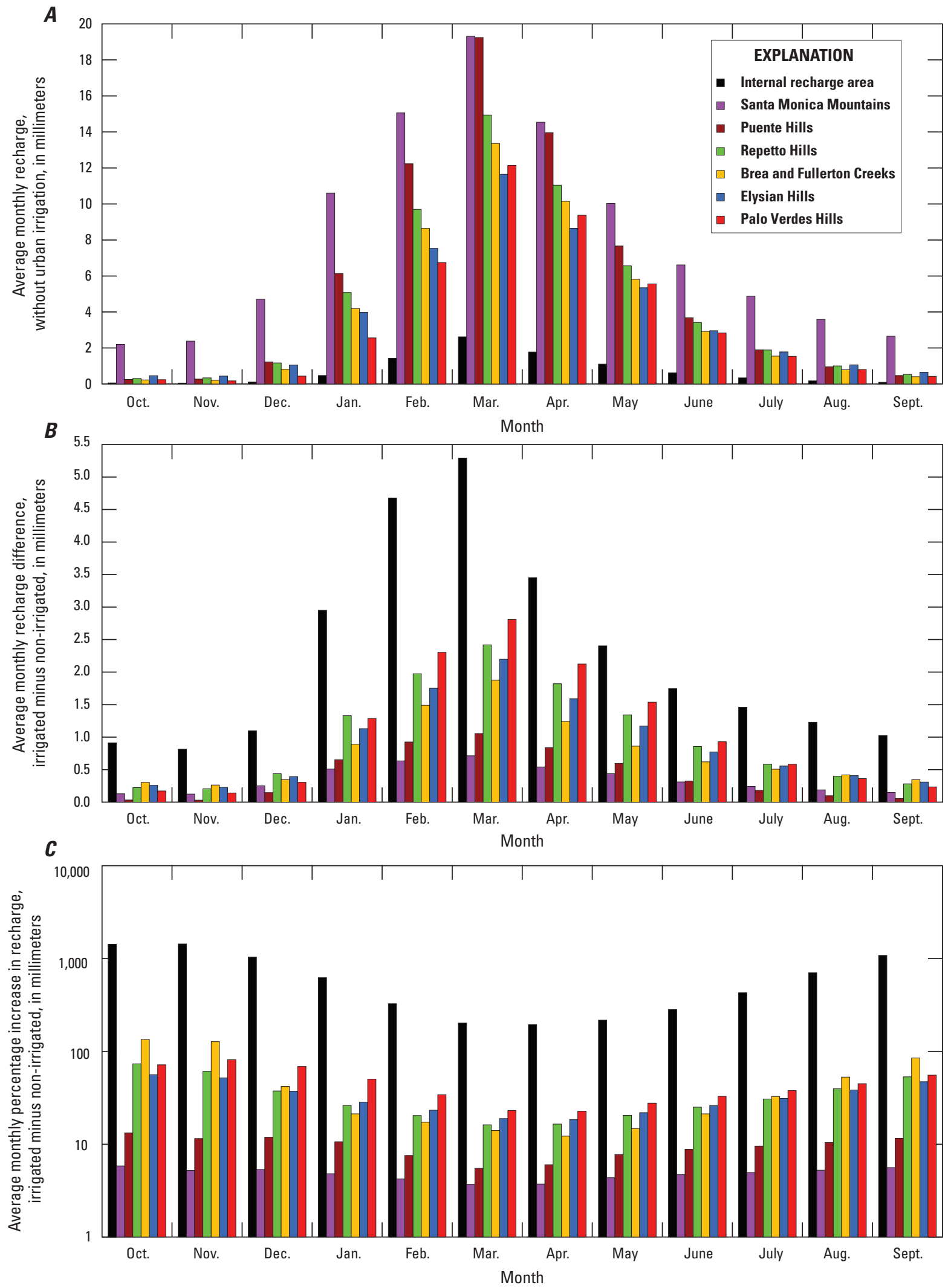

Figure 47. Comparison of average monthly simulated recharge, Los Angeles Basin watershed model (LABWM), California: $A$, average monthly recharge without irrigation; $B$, average monthly difference in recharge with and without urban irrigation; $C$, average monthly percentage increase in recharge with irrigation. 
$\boldsymbol{A}$

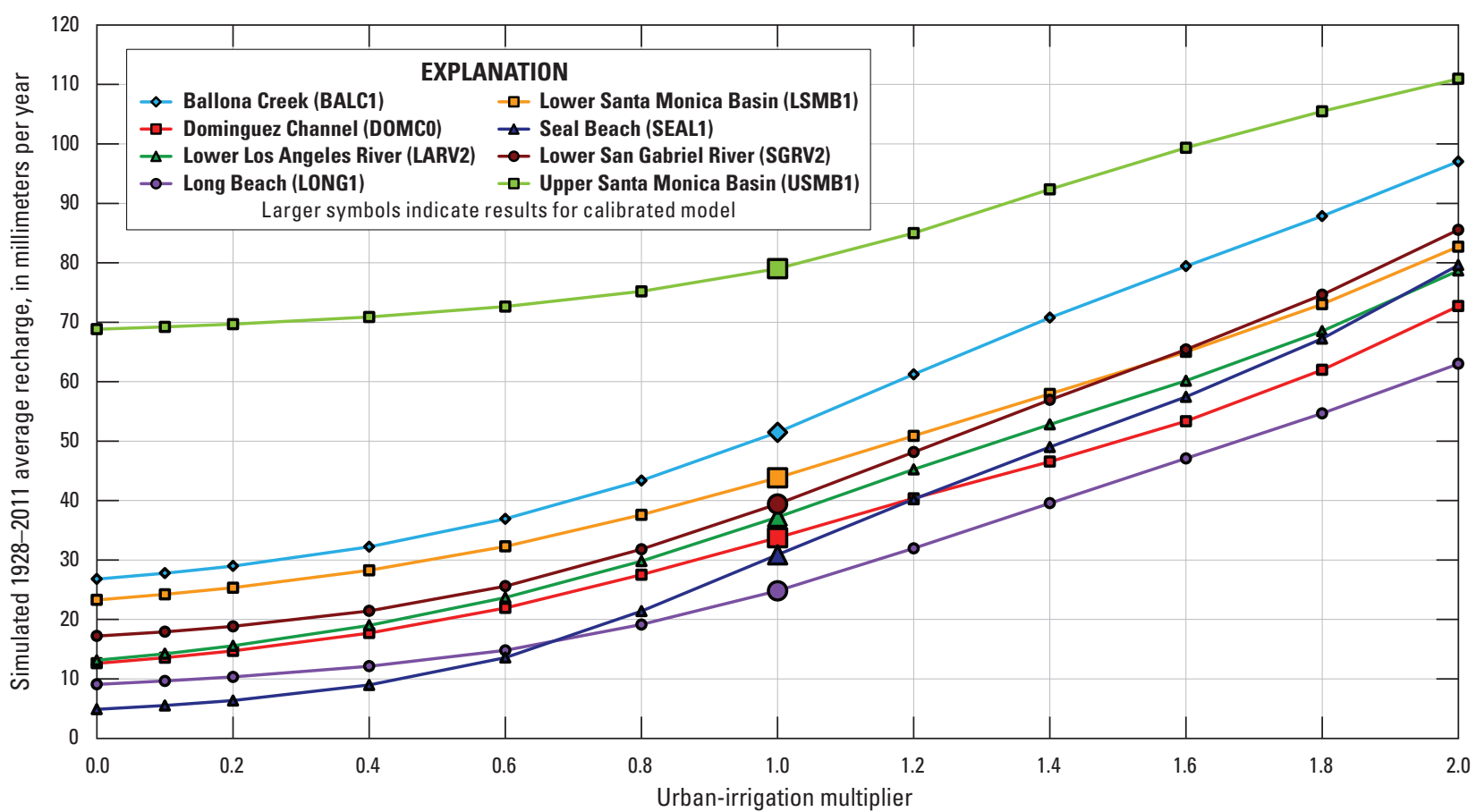

B

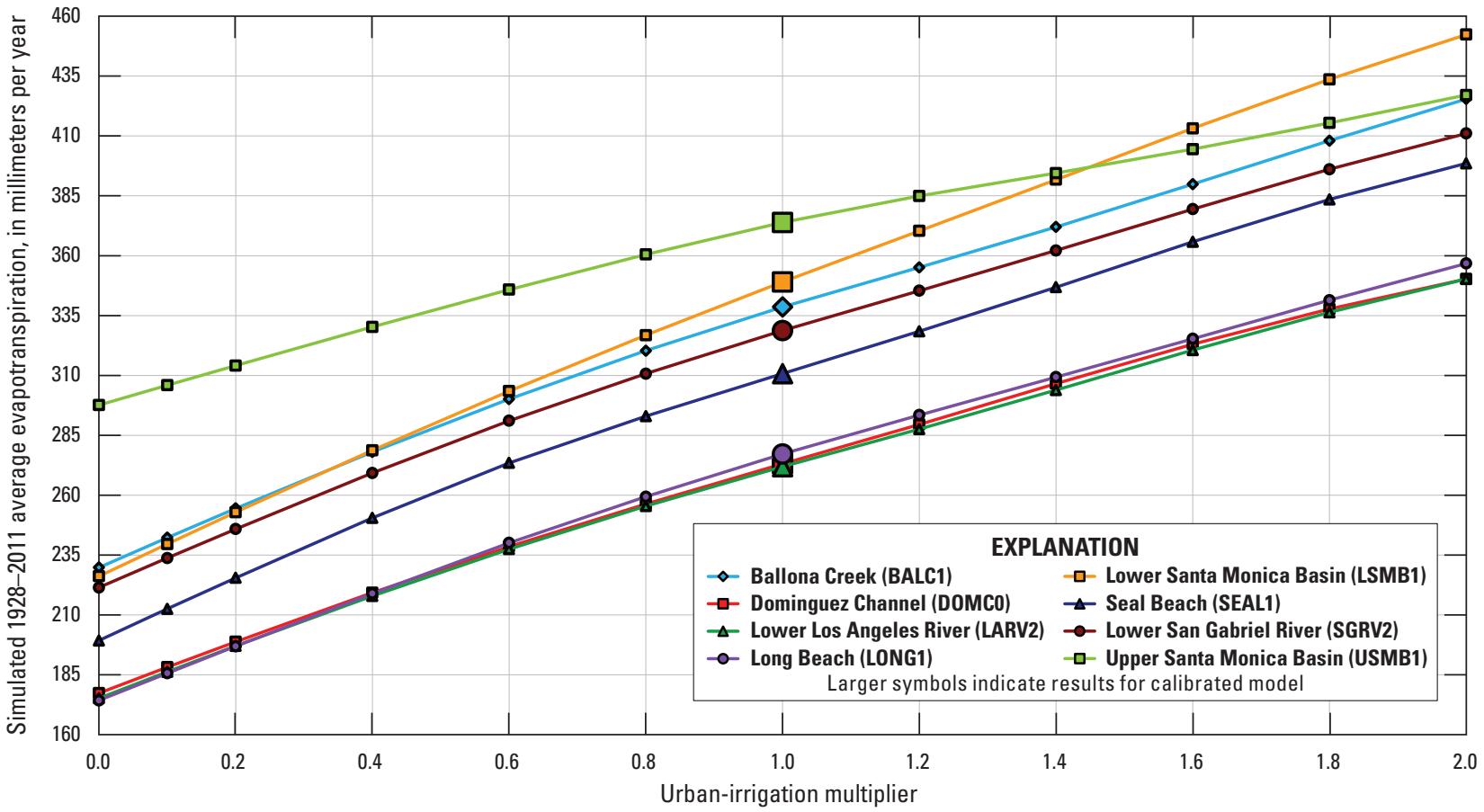

Figure 48. Comparison of simulation results for subdomains by using a range of urban irrigation estimates, Los Angeles Basin watershed model (LABWM), California: $A$, average 1928-2011 recharge; $B$, average 1928-2011 evapotranspiration. 
The upper Santa Monica Basin (USMB) subdomain had the highest ET rate for urban-irrigation multipliers of 1.4 and less (fig. 48B). For multipliers of 1.6 and greater, the LSMB subdomain had the highest ET rate, which reached a maximum of $452 \mathrm{~mm} / \mathrm{yr}$ with a multiplier of 2.0. In contrast to the results obtained for recharge, simulated ET was similar for the Dominguez Channel (DOMC), Long Beach (LONG), and lower Los Angeles River (LARV) subdomains over the entire range of urban-irrigation multipliers.

For all eight subdomains, the percentage of urban irrigation contributing to recharge increased as urban irrigation increased, whereas the percentage of irrigation contributing to ET decreased (fig. 49). At a multiplier of 0.1, urban irrigation varied between 8 and $14 \mathrm{~mm} / \mathrm{yr}$ for the eight subdomains, contributing about 4 to 9 percent to recharge (fig. 49A) and 91 to 95 percent to ET (fig. 49B). At a multiplier of 2.0, urban irrigation varied from about 175 to $289 \mathrm{~mm} / \mathrm{yr}$, contributing 20 to 27 percent of the irrigated water to recharge (fig. 49A) and 72 to 78 percent to ET (fig. 49B). For all ranges and all subdomains, most of the urban irrigation was returned to the atmosphere by ET. Runoff and the average root-zone water content were also affected by variations in urban irrigation estimates; however, the relative changes to these components of the water balance were small compared to recharge and ET. At an urban-irrigation multiplier of 2.0, simulated runoff increased by less than 2 percent for all subdomains.

\section{Comparison with Previous Recharge Estimates}

The recharge estimates developed by using the LABWM were compared with recharge estimates developed previously by Reichard and others (2003) for water years 1971-2000. By using the method applied in developing recharge estimates for the LAGSA, the total recharge estimated for the groundwater model defined in Reichard and others (2003) included both a direct-recharge component for the area of the groundwater model and also a mountain-front recharge component from the tributary upland areas bordering the model domain (fig. 50). For this analysis, the mountain-front recharge component included seven tributary upland areas bordering the model area. In addition to the recharge comparison, the LABWM spatially interpolated precipitation was compared with precipitation values used in Reichard and others (2003) to develop the transient recharge estimates.

The comparison between annual precipitation estimated with the LABWM and annual precipitation used in Reichard and others (2003) showed agreement between the annual and long-term average precipitation used to estimate recharge in both studies (fig. 51A). The greatest differences in precipitation estimates were for water years 1975, 1984, and 1992. Agreement was good for most wetter than average water years, such as 1978, 1983, and 1998. The long-term average for water years 1971-2000 applied by Reichard and others (2003) was $391 \mathrm{~mm} / \mathrm{yr}$, which is comparable to the long-term average of $389 \mathrm{~mm} / \mathrm{yr}$ estimated by the LABWM for the same period.

The LABWM simulated 30-year-average recharge of 7,975 ha-m/yr was in close agreement with the average of 8,321 ha-m/yr obtained by Reichard and others (2003; fig. 51B). The comparison of annual recharge, however, indicated a greater degree of annual variability in recharge estimated by the LABWM relative to the estimates obtained by Reichard and others (2003). For water years 1971-2000, annual recharge greater than 21,000 ha-m was simulated for water years 1978 and 1998, whereas annual recharge of 10,300 was estimated by Reichard and others (2003) for the same years. For most water years, including years with averageto-below-average precipitation, recharge simulated by the LABWM was less than that estimated by Reichard and others (2003). It should be noted that the estimates in Reichard and others (2003) were developed as the boundary condition for a calibrated groundwater-flow model and, therefore, indirectly accounted for the damping effect of the deeper unsaturated zone in terms of reducing year-to-year variability in recharge (this damping effect was not accounted for by the LABWM). The temporal pattern of annual recharge was generally similar for the two recharge estimates, with water years 1978-80, 1983, 1993, 1995, and 1998 all indicating greater than average recharge.

The LABWM results indicated that most of the recharge volume was in the internal recharge area, which is similar to the previous recharge estimates obtained for the LAGSA. The 30-year-average direct recharge simulated by the LABWM for the internal area was 5,350 ha-m/yr, compared to only 2,650 ha-m/yr simulated by the LABWM for the contributing mountain-front recharge areas.

The LABWM results were also compared to previous estimates of recoverable water for basins in the southern California region (Crippen, 1965). Recoverable water was defined by Crippen (1965) as the sum of recharge and runoff. For the comparison, recoverable water was plotted against effective precipitation in the LABWM subbasins and the basins analyzed by Crippen (1965). The LABWM results both included the with and without urban irrigation simulations. For the with irrigation results, the sum of precipitation and irrigation was referred to as effective precipitation. The LABWM results tended to indicate greater recoverable water amounts for a given amount of effective precipitation compared to results obtained by Crippen (1965; fig. 52). The high percentage of impervious area used in the LABWM likely caused more runoff than in most of the basins analyzed by Crippen (1965). A better match between the LABWM results and the estimates of recoverable water by Crippen (1965) was obtained when urban irrigation was included. 
$\boldsymbol{A}$
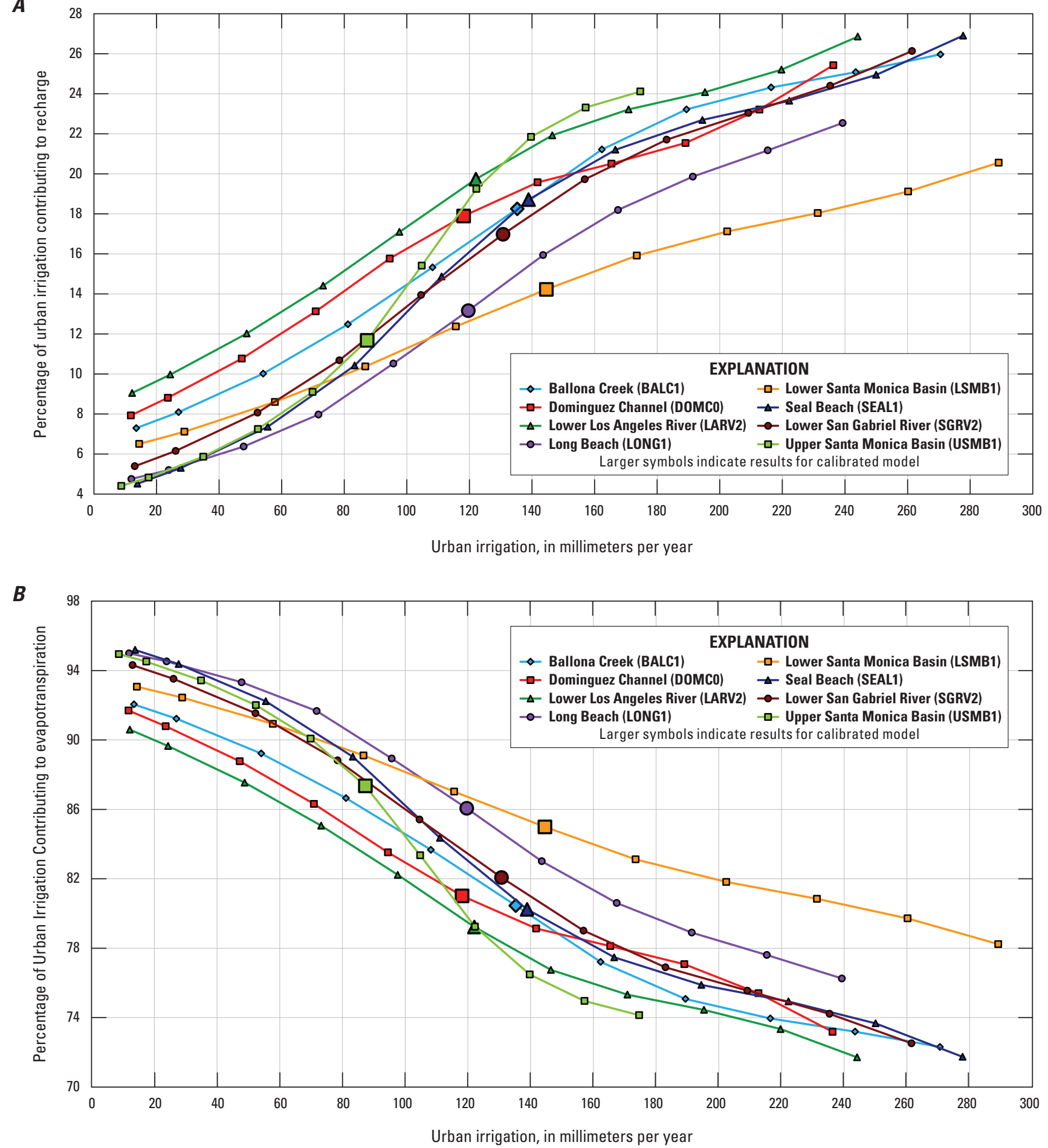

Figure 49. Comparison of simulation results for subdomains by using a range of urban irrigation estimates, Los Angeles Basin watershed model (LABWM), California: $A$, percentage of contribution of urban irrigation to recharge; $B$, percentage of contribution of urban irrigation estimates to evapotranspiration. 


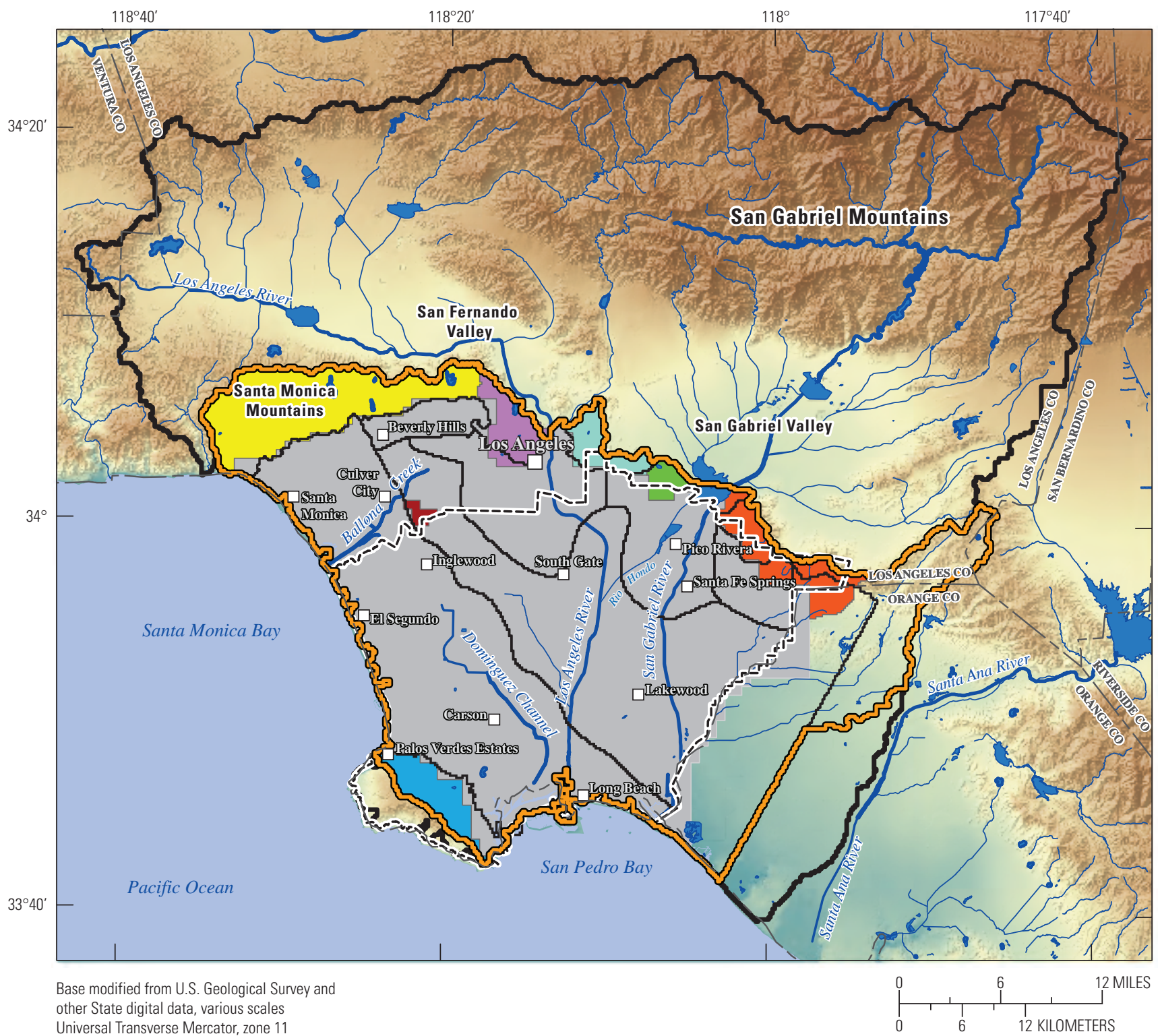

Universal Transverse Mercator, zone 11

North American Datum 1983

\section{EXPLANATION}

Recharge areas used for comparison to previous recharge estimates

Internal recharge area

Contributing recharge areas

$\square$ Baldwin Hills

Elysian Hills

$\square$ Merced Hills

Los Angeles Basin watershed model area boundary

Water Replenishment District

Los Angeles recharge study area

Water bodies and flood-control areas

Major rivers and streams

_ Minor rivers and streams

— Los Angeles groundwater basins

- - County line

Palo Verdes Hills

Repetto Hills

Santa Monica Mountains

Figure 50. Internal and contributing recharge areas used for previous recharge estimates, Los Angeles Basin watershed model (LABWM), California. 
$\boldsymbol{A}$

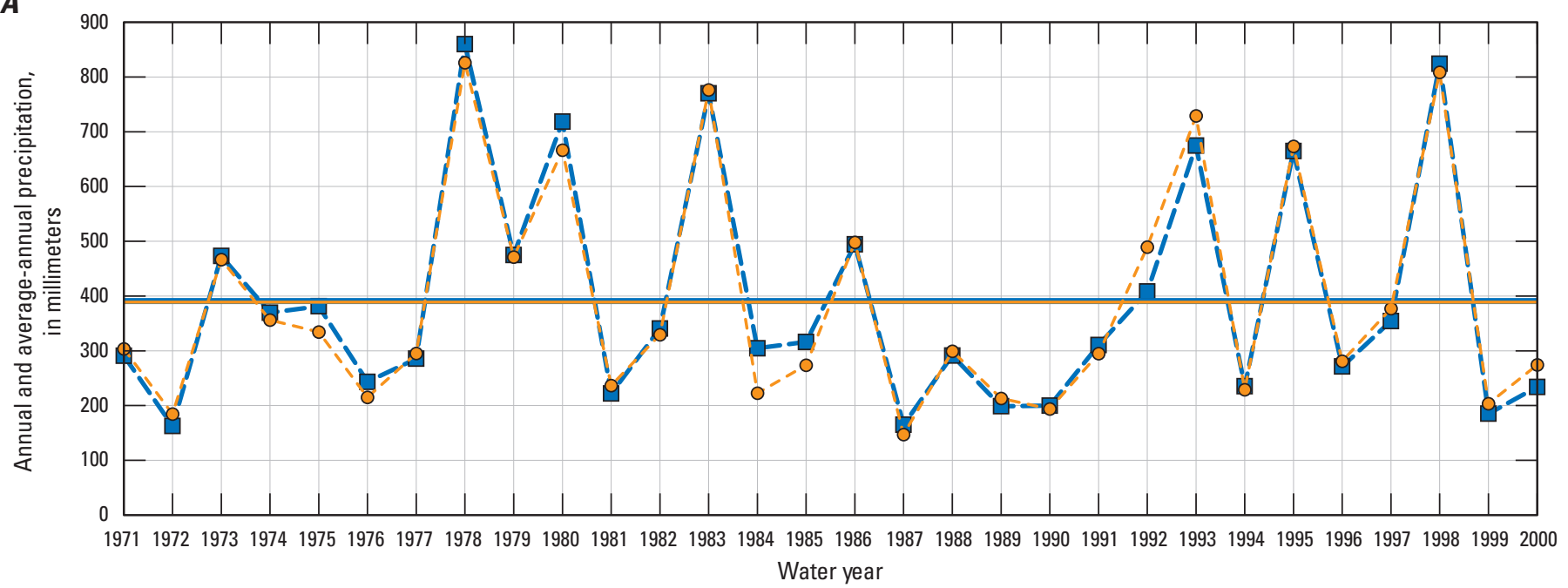

EXPLANATION

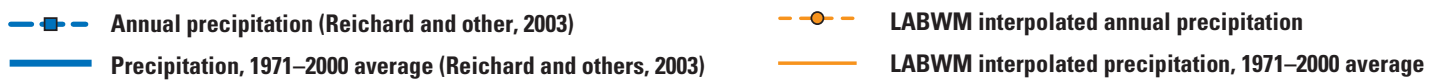

B

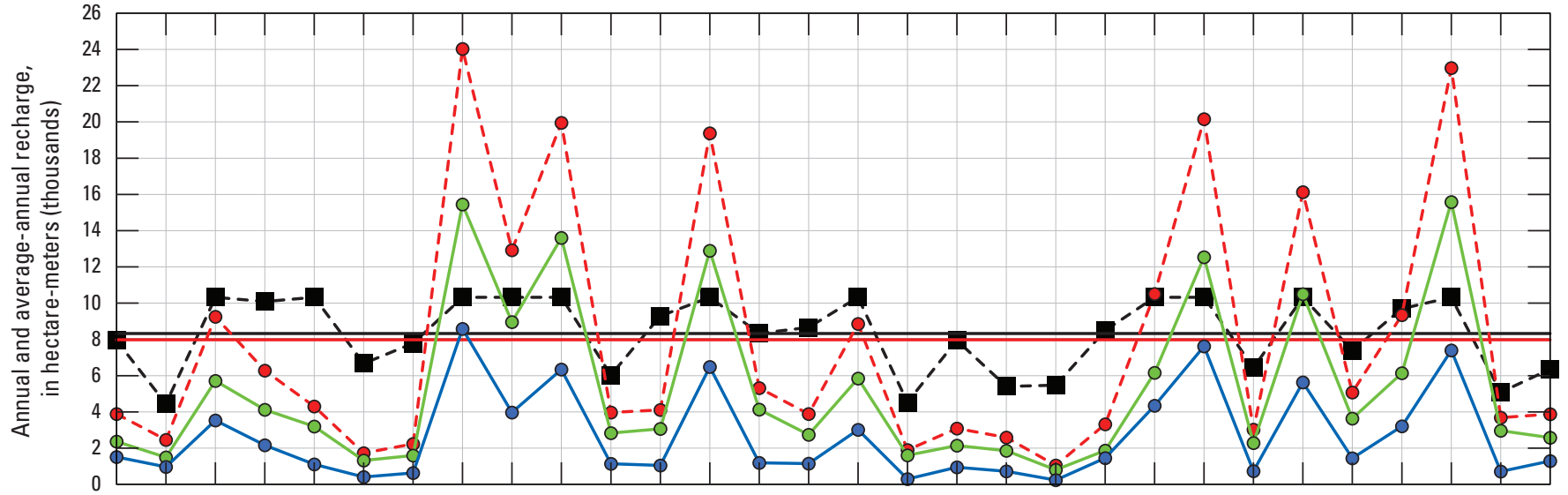

197119721973197419751976197719781979198019811982198319841985198619871988198919901991199219931994199519961997199819992000 Water year

\section{EXPLANATION}
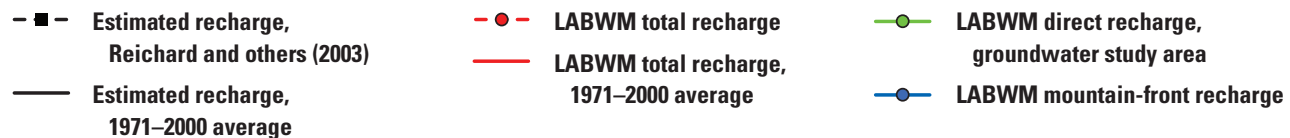

Figure 51. Comparison of annual results from a previous study and results from using the Los Angeles Basin watershed model (LABWM), California, for $A$, precipitation; and $B$, recharge. 


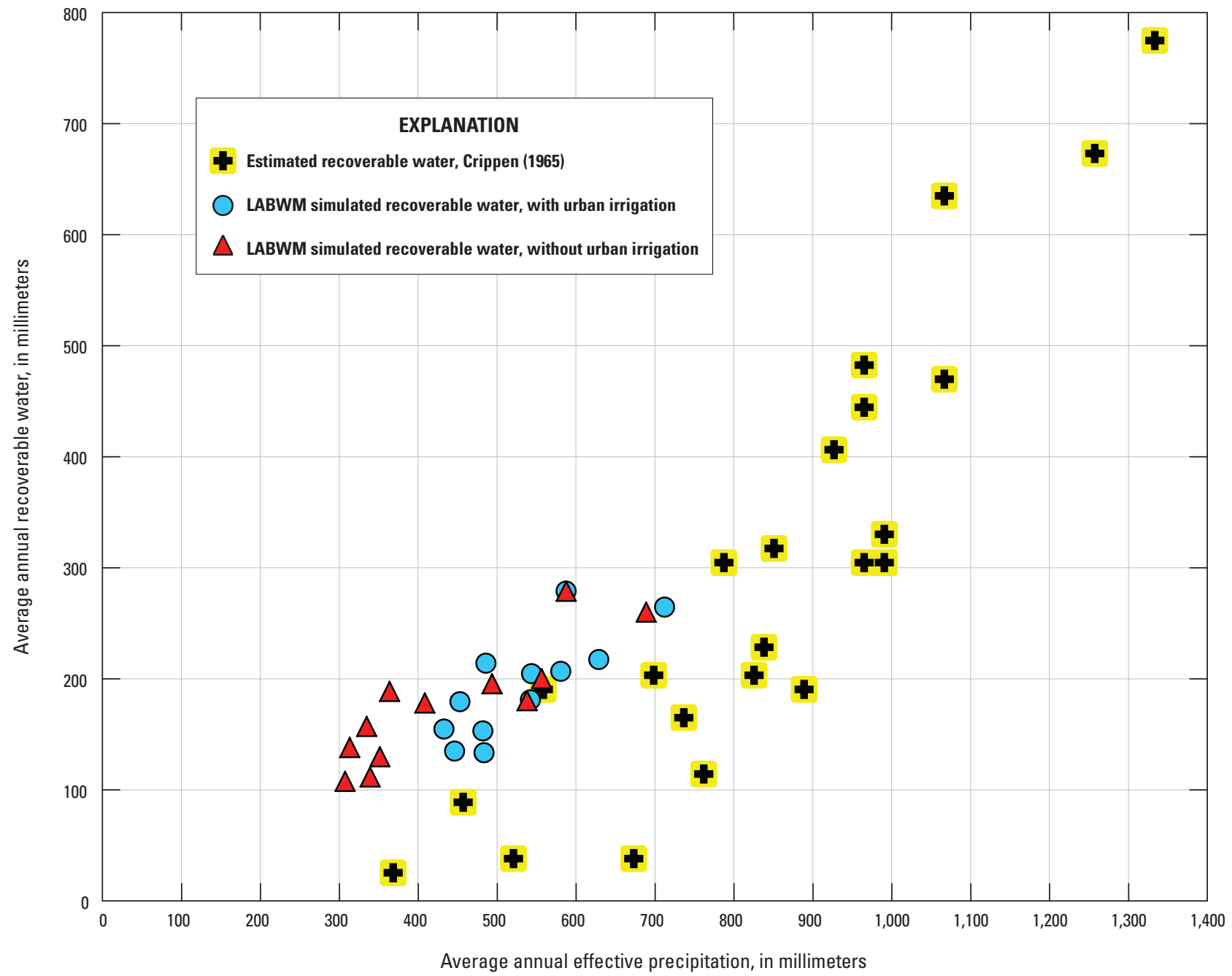

Figure 52. Comparison of recoverable water with effective precipitation obtained with previous studies and with the Los Angeles Basin watershed model (LABWM), California. 


\section{Model Limitations}

A primary limitation of the LABWM applied in this study is the uncertainty in model calibration using a comparison of simulated runoff to available streamflow records. The LABWM does not account for regulated streamflow, and only a few unregulated streamflow records were available for calibration. The watershed area upstream from the unregulated streamflow-gaging stations used for calibration included only a fraction of the total area modeled by using the LABWM. In addition, the length of most of the streamflow records used for model calibration did not span the full simulation period. Model uncertainty for simulated recharge is assumed to be greater than simulated runoff because the model is not calibrated directly to recharge data, which generally is not available. Additional data used for calibration, such as measurements of soil moisture at varying depths and times, could greatly reduce the uncertainty in simulated recharge.

A major assumption applied in the LABWM was that runoff generated in response to rainfall, snowmelt, irrigation, and shallow subsurface-seepage flow is the primary component of streamflow measured in the study area. Streamflow resulting from deep groundwater discharge, wastewater discharge, or flow diversions was not represented by the LABWM. In addition, simulation of streamflow was based on a daily routing algorithm that assumed all streamflow either discharges from the drainage basin or infiltrates into the root zone at the end of each day. This limitation could cause an overestimation of streamflow and a corresponding under- or overestimation of recharge. Streamflow was overestimated because the dampening effect (time delay) caused by channel storage of water (including reservoirs and retention basins) was not accounted for. This increased streamflow either can cause an over- or underestimation of recharge, depending on the location and the effective hydraulic conductivity of the channel represented by the model.

Dispersive streamflow (divergent as opposed to convergent streamflow), which can be an important characteristic of streamflow and overland flow across alluvial fans and basins with braided channels, was not directly represented in the surface-water flow-routing algorithm. All surface-water flow was simulated as convergent streamflow. These limitations in simulating surface-water flow could result in an overestimation of recharge in some parts of the study area, particularly in the higher elevation sub-drainage basins and along the mountain front to basin transition.

Although relatively high-resolution (30-m) data were used in this study for defining the percentage of impervious areas for model cells, uncertainty remains about the effective impervious area represented in the model. The effective impervious area includes only those impervious surfaces generating runoff that is routed to downstream cells. In actuality, a large amount of runoff generated by impervious surfaces is routed to pervious areas in the same cell, rather than a downstream cell. For example, runoff from an impervious roof can be routed directly to the pervious lawn area rather than an impervious street gutter or storm drain. Impervious area runoff routed to pervious areas potentially does not generate runoff for the cell.

Storm runoff is modeled as a cascading flow process in the LABWM. For a given cell, surface-water run-on (inflow from upstream cells) is distributed to the area of the cell (as a uniform inflow depth). In developed urbanized areas, however, storm runoff from impervious areas is usually collected by a network of storm drains that directly connect with the main channels. In doing so, the storm drains cause a more rapid hydrologic response to storms. Although the LABWM empirically accounts for channelized flow in the larger channels, the highly channelized flow along street gutters and through the storm-drain network is not directly represented by the model.

The physical characteristics of the watersheds defined in the LABWM are static; they do not change with time. Changes in land use and land cover caused by factors such as urbanization and wildfires can cause great changes through time in imperviousness, vegetation, land-cover characteristics, and stream-channel characteristics that are not represented by the model. Examination of land-use data sets and results from model calibration and testing indicated that watershed characteristics were likely to have changed notably during the target-simulation period (water years 1915-2014).

Although snow does not fall in the LAGSA or in most of the LABWM area, snow is an important component of the hydrologic system in the higher elevation drainages of the San Gabriel Mountains. The streamflow records used for model calibration did not include these higher elevation drainages, and therefore, the calibrated model had a high degree of uncertainty in the simulation of snow fall and snow melt in the San Gabriel Mountains. In the LABWM area, snow was simulated only when the average daily air temperature was $0{ }^{\circ} \mathrm{C}$ or less. In actuality, notable snow can accumulate can during storms when the average recorded air temperature is greater than $0{ }^{\circ} \mathrm{C}$. Additional model calibration for the headwater drainages in the San Gabriel Mountains could improve the simulation of recharge and runoff for these locations.

Additional limitations are associated with the urbanirrigation estimates developed in this study. A key assumption of the minimum-month method is that during the minimummonth, landscaped vegetation does not receive any irrigation, but relies solely on natural rainfall. This is most likely not the case in many areas of the southwest, where rainfall can be sporadic, and home owners leave automatic sprinkler systems turned on. Consequently, the minimum-month method is prone to an underestimation of outdoor water use (Department of Water Resources, 1994; DeOreo and others, 1996; Mayer and others, 1999; Gleick and others, 2003).

Another assumption was that the irrigation rate for single-family neighborhoods was representative of the rate in other land-use classes. Typical residential neighborhood landscaping consists of grasses, trees, and bushes, which is similar to the landscaping in commercial or other urbanized 
land uses. Theoretically, the water used to maintain those plants is similar, regardless of the type of land-use class in which they are maintained; however, this assumption has not been validated to date.

A further consideration is that of the land-use map. Land cover for a select number of land-use classes in the San Fernando Valley was hand digitized in order to test the accuracy of the reported imperviousness from the LACDPW (Johnson and Belitz, 2012). The results showed that the LACDPW dataset was very good at estimating perviousness in the less vegetated land-use classes, but overestimated it in the single-family residential class. An overestimation would cause more water to be applied to the landscape.

Lastly, if a particular land use was designated as containing irrigated vegetation (table 10), it was assumed that all pervious areas in that land use were irrigated. This is not always the case, however. Many pervious areas, such as barren landscapes or vacant land parcels, are not irrigated.

Daily PET was simulated by using an hourly time step and an energy-balance model to improve the representation of the shading effects of rugged terrain relative to changes in solar position during the year (Flint and Childs, 1987). Daily ET was simulated as a combined function of daily PET; the vertical distribution of available water in the root-zone layers; and the root-zone density, where the root-zone density represents the characteristics of vegetation. Variations in root density were not adjusted or varied according to differences in soil texture; however, the effect of soil properties on ET was accounted for indirectly by differences in layer thickness, water-holding capacity, and vertical hydraulic conductivity.

\section{Summary and Conclusions}

A daily precipitation-runoff model, the Los Angeles Basin watershed model (LABWM), was used to estimate recharge and runoff for the principal groundwater basins underlying the greater Los Angeles area, referred to in this study as the Los Angeles groundwater study area (LAGSA). The area of interest for estimating recharge to the LAGSA, the Los Angeles recharge-study area, included tributary drainages upstream from and peripheral to the LAGSA boundary. The tributary drainages have the potential to contribute a large amount of recharge to the LAGSA. The LABWM uses the distributed-parameter INFILv3 precipitation-runoff modeling code for simulating spatially and temporally variable recharge and runoff on a daily time step. The recharge estimates were used to develop spatially and temporally distributed recharge for the LAGSA and also mountain-front recharge for the peripheral drainages. The mountain-front recharge simulated for the tributary upland areas bordering the LAGSA was combined with the direct recharge simulated for the internal area of the LAGSA in order to define the total potential transient recharge for the LAGSA. An important aspect of the application of the LABWM for recharge estimation is that the effect of climate variability on recharge is deterministically simulated by using a process-based daily water balance calculation, rather than an empirical approach, where recharge is estimated as a statistical function of precipitation. Variations in recharge in response to the spatial variability of watershed characteristics are also directly accounted for in the distributed-parameter, deterministic simulation. Another important aspect of the LABWM application for estimating recharge is that urban irrigation was included in the daily water-balance simulation and, therefore, it accounted for increased recharge from urban irrigation return flows.

A gridded discretization of the LABWM area was used to represent spatially distributed climate and watershed characteristics affecting the surface and shallow sub-surface hydrology. Daily climate data obtained from a local network of 201 monitoring sites and PRISM-derived average monthly precipitation and maximum and minimum air temperature maps for the 30-year period (1971-2000) were used to develop the climate inputs for the LABWM. Data from 2001 defining topography, land use, land cover, soils, vegetation, and surficial geology were used as input to represent the contemporary conditions of the physical characteristics of the LABWM area. A new method for estimating urban irrigation (representing mostly residential and commercial landscape watering) based on land use and the percentage of imperviousness was incorporated into the LABWM. The urban-irrigation estimates were defined on a quarterly basis to account for seasonal changes in water demand.

The LABWM was calibrated by using available records of streamflow at six streamflow gaging stations within the LABWM. The six gages included three gages with drainage areas in the LAGSA and three gages outside of, but next to, the LAGSA. The calibration was limited because the drainage areas for the six gages did not include most of the LABWM area and because the drainage areas upstream from the gages did not represent all the characteristics and conditions of the LABWM area. The comparison between simulated and measured streamflow was good for the three gages in the LAGSA and satisfactory for the three gages next to the LAGSA, indicating an acceptable overall calibration for the six gages and for most of the goodness-of-fit statistics considered. The satisfactory calibration result included PAEE values within plus or minus 20 percent and NSME values of 0.7 or greater for most of the streamflow components analyzed for all six gages.

The best calibration was obtained for gage BALC6, with a PAEE of -6 and NSME values of 0.74 for daily streamflow, 0.93 for monthly streamflow, and 0.82 for average water year streamflow. The next best calibration was obtained for gage COYC1, with PAEE values of 10 to 11 and NSME values of 0.77 for daily mean discharge, 0.87 for average monthly streamflow, and 0.83 for average water year streamflow. Results for gage ALHW6 showed a good calibration for daily and monthly streamflow, with NSME values of 0.78 and 0.94, respectively. Calibration results for average water-year streamflow, however, were poor for gage ALHW6, with an 
NSME of only 0.52 . There was a moderate tendency of the model to underestimate streamflow at this location, resulting in PAEE values of -14 to -18 . Calibration results for gage COMP4 were good for daily and monthly streamflow, with a PAEE of 18 and NSME values of 0.76 for daily flow and 0.81 , for monthly flow; however, the results for average wateryear streamflow indicated a poor calibration, with a PAEE of 23 and NSME of only 0.57 . For this location, there was a moderate tendency of the model to overestimate streamflow. The NSME results for gage SJCE1 were good for daily, monthly, and average water-year streamflow, with values of 0.74 or greater. The best results for gage SJCE1 were obtained for monthly streamflow, with an NSME of 0.91 indicating an excellent model fit. The PAEE of -16 for gage SJCE1 indicated an overall tendency to underestimate streamflow but was considered satisfactory for model calibration and was within the PAEE calibration criteria of plus or minus 20 that was used in calibrating the LABWM. The PAEE results of 3 and 4 obtained for gage TOPG1 indicate a very good calibration in terms of minimal estimation bias. The monthly NSME of 0.68 and the annual result of 0.73 indicated satisfactory and good calibration results, respectively, however the daily NSME result of 0.35 indicated a poor fit to daily streamflow at gage TOPG1.

Model application to a 100-year target-simulation period, from water years 1915 through 2014, was used to quantify and evaluate spatial and temporal variability of water-budget components, including evapotranspiration (ET), recharge, and runoff. The largest outflow of water from the LABWM area was ET; the 100-year average ET rate of $362 \mathrm{~mm} / \mathrm{yr}$ (182,473 ha-m/yr) represented 65 percent of the combined water inflow of $488 \mathrm{~mm} / \mathrm{yr}(246,405 \mathrm{ha}-\mathrm{m} / \mathrm{yr})$ from precipitation and $63 \mathrm{~mm} / \mathrm{yr}$ (31,906 ha-m/yr) from urban irrigation. Simulated ET rates within the LABWM area varied from a minimum of $0-100 \mathrm{~mm} / \mathrm{yr}$ for impervious areas to high values of more than $1,000 \mathrm{~mm} / \mathrm{yr}$ for many locations, including the south-facing slopes of the San Gabriel Mountains, stream channels underlain by permeable soils and thick root zones, and pervious locations receiving inflows both from urban irrigation and runoff. After ET, surface-water runoff was the next largest outflow from the LABWM, averaging $145 \mathrm{~mm} / \mathrm{yr}$ (73,212 ha-m/yr) for the 100-year period, or 26 percent of the combined precipitation and urban irrigation inflow. Recharge averaged $45 \mathrm{~mm} / \mathrm{yr}$ $(22,577 \mathrm{ha}-\mathrm{m} / \mathrm{yr})$, or about 8 percent of the combined inflow from precipitation and urban irrigation.

Simulation results indicated that recharge in response to urban irrigation was an important component of spatially distributed recharge, contributing more than 50 percent of the total recharge to many of the groundwater basins in the LAGSA. For the eight subdomains included in the LABWM area that contained the LAGSA, urban irrigation contributed $23 \mathrm{~mm} / \mathrm{yr}(4,733 \mathrm{ha}-\mathrm{m} / \mathrm{yr})$ to the total recharge of $41 \mathrm{~mm} / \mathrm{yr}$ (8,473 ha-m/yr), accounting for 56 percent of the total recharge.
Simulation results indicated that mountain front recharge from adjacent upland areas and hilly drainages outside of but tributary to the lower lying area of the groundwater basins made an important contribution to the total recharge. The mountain front recharge was assumed to occur as groundwater underflow from the upland areas into the LAGSA, and was assumed to be equal to the total direct recharge simulated for upland drainages. The time-averaged recharge rate was similar to the combined direct- and mountain-front recharge estimates developed in a previous study of the LAGSA and used as input for a calibrated groundwater flow model. The annual (water year) recharge estimates provided by the LABWM simulation, however, indicated much greater year-to-year variability compared to the previous estimates that were based on an empirical function of annual precipitation. The greater year-to-year variability in the LABWM recharge estimate was most strongly correlated to the year-to-year variability in precipitation and to variations in the timing, magnitude, and frequency of daily precipitation. In addition, the LABWM recharge estimates indicate a high degree of spatial variability caused by spatially varying drainage basin characteristics, climate, and urban irrigation.

\section{References Cited}

Beven, K. J., and Kirkby, M. J., 1979, A physically based, variable contributing area model of basin hydrology: Hydrological Sciences-Bulletin, no. 24, v. 1, p. 43-69, http://soilandwater.bee.cornell.edu/research/VSA/papers/ BevenHSB79.pdf.

California Department of Forestry and Fire Protection, 2002, Monitoring land cover changes in California: California Land Cover Mapping and Monitoring Program, South Coast Project Area, July 2002, 161 p., accessed January 20, 2015, at http://frap.cdf.ca.gov/projects/land_cover/monitoring/ pdfs/socdp_final2.pdf.

California Department of Fish and Wildlife. California Interagency Wildlife Task Group, 2014, User's manual for version 9.0 of the California Wildlife Habitat Relationships System and Bioview: Sacramento, California, 54 p., https://www.dfg.ca.gov/biogeodata/cwhr/.

California Department of Water Resources, 1975, California's ground water: State of California Bulletin no. 118, 8 p., http://water.ca.gov/groundwater/bulletin118.cfm.

California Department of Water Resources, 1994, Urban water use in California: State of California Bulletin No. 166-4, http://www.water.ca.gov/historicaldocs/irwm/b166-1994/ ch1.html. 
California Irrigation Management Information System (CIMIS), 2005, Meteorological data: California Department of Water Resources and University of California at Davis, http://www.cimis.water.ca.gov/.

City of Los Angeles Department of Water and Power, 2001, Urban water management plan, fiscal year 2000-2001 annual update: City of Los Angeles, Los Angeles, Calif.

Crippen, J.R., 1965, Natural water loss and recoverable water in mountain basins of southern California: U.S. Geological Survey Professional Paper 417-E, p. E1-E24, https://pubs.er.usgs.gov/publication/pp417E.

Daly, C., Neilson, R.P., and Phillips, D.L., 1994, A statisticaltopographic model for mapping climatological precipitation over mountainous terrain: Journal of Applied Meteorology, v. 33, no. 2, p. 140-158.

Daly, Christopher, Gibson, Wayne, Doggett, Matt, Smith, Joseph, and Taylor, George, 2004, Up-to-date monthly climate maps for the conterminous United States: Procedures of the 14th American Meteorological Society Conference on Applied Climatology, 84th AMS Annual Meeting Combined Preprints, American Meteorological Society, Seattle, Washington, January 13-16, 2004, Paper P5.1, CD-ROM, http://www.prism.oregonstate.edu/ documents/pubs/2004appclim_monthlyMaps_daly.pdf.

DeOreo, W.B., Heaney, J.P., and Mayer, P.W., 1996, Flow trace analysis to assess water use: Journal of the American Water Works Association, January 1996, v. 88, no. 1, p. 79-90, http://www.awwa.org/publications/journal-awwa/ abstract/articleid/13497/issueid/33522453.aspx?getfile=11 pers75apppcr|personify \serverfiles\dcdfiles $\backslash 13497 \backslash$ waternet.0039526.pdf.

Farrar, C.D., Metzger, L.F., Nishikawa, Tracy, Koczot, K.M., and Reichard, E.G., 2006, Geohydrological characterization, water-chemistry, and ground-water flow simulation model of the Sonoma Valley area, Sonoma County, California, with a section on Basement rock configuration interpreted from gravity data by Victoria E. Langenheim: U.S. Geological Survey Scientific Investigations Report 2006-5092, 167 p., https://pubs.er.usgs.gov/publication/sir20065092.

Flint, A.L., and Childs, S.W., 1987, Calculation of solar radiation in mountainous terrain: Journal of Agricultural and Forest Meteorology, v. 40, no. 3, p. 233-249, http://dx.doi.org/10.1016/0168-1923(87)90061-X.

Flint, L. E., and Flint, A. L., 2007, Regional analysis of ground-water recharge, in Stonestrom, D.A., Constantz, Jim, Ferre, T.P.A., and Leake, S.A., eds., Ground-water recharge in the arid and semiarid southwestern United States: U.S. Geological Survey Professional Paper 1703-B, p. 29-60, https://pubs.er.usgs.gov/publication/pp1703B.
Flint, L.E., and Flint, A.L., 2012, Simulation of climate change in San Francisco Bay Basins, California: Case studies in the Russian River Valley and Santa Cruz Mountains: U.S. Geological Survey Scientific Investigations Report 2012-5132, 55 p., https://pubs.er.usgs.gov/publication/sir20125132.

Flint, L.E., and Martin, Peter, eds., with contributions by Brandt, Justin, Christensen, A.H., Flint, A.L., Flint, L.E., Hevesi, J.A., Jachens, Robert, Kulongoski, J.T., Martin, Peter, and Sneed, Michelle, 2012, Geohydrology of Big Bear Valley, California: Phase 1-Geologic framework, recharge, and preliminary assessment of the source and age of groundwater: U.S. Geological Survey Scientific Investigations Report 2012-5100, 112 p., https://pubs.er.usgs.gov/publication/sir20125100.

Gleick, P.H., Haasz, Dana, Henges-Jeck, Christine, Srinivasan, Veena, Wolff, Gary, Cushing, K.K., and Mann, Amardip, 2003, Waste not, want not: The potential for urban water conservation in California: Pacific Institute for Studies in Development, Environment, and Security. 165 p., http://www.pacinst.org/wp-content/uploads/ sites/21/2013/02/waste_not_want_not_full_report3.pdf.

Grimmond, C.S.B. and Oke, T.R., 1986, Urban water balance: 2. Results from a suburb of Vancouver, British Columbia: Water Resources Research, v. 22, no. 10, p. 1404-1412, http://dx.doi.org/10.1029/WR022i010p01404.

Grimmond, C.S.B., Oke, T.R., and Steyn, D.G., 1986, Urban water balance: 1 . A model for daily totals: Water Resources Research, v. 22, no. 10, p. 1397-1403, http://dx.doi.org/10.1029/WR022i010p01397.

Hevesi, J.A., and Christensen, A.H., 2015, Estimating natural recharge in San Gorgonio Pass watersheds, California, 1913-2012: U.S. Geological Survey Scientific Investigations Report 2015-5122, 74 p., http://dx.doi.org/10.3133/sir20155122.

Hevesi, J.A., Flint, A.L., and Flint, L.E., 2003, Simulation of net infiltration and potential recharge using a distributedparameter watershed model of the Death Valley region, Nevada and California: U.S. Geological Survey WaterResources Investigation Report 2003-4090, 171 p., https://pubs.er.usgs.gov/publication/wri034090.

Hevesi, J.A., Flint, L.E., Church, C.D., and Mendez, G.O., 2011, Application of a watershed model (HSPF) to evaluating sources and transport of pathogen indicators in the Chino Basin drainage area, San Bernardino County, California: U.S. Geological Survey Scientific Investigations Report 2009-5219, 142 p., https://pubs.er.usgs.gov/publication/sir20095219.

Jennings, C.W., 1977, Geologic map of California: California Division of Mines and Geology Geologic Data Map no. 2, scale 1:750,000. 
Jeton A.E., and Maurer, D.K., 2011, Precipitation and runoff simulations of select perennial and ephemeral watersheds in the middle Carson River basin, Eagle, Dayton, and Churchill Valleys, west-central Nevada: U.S. Geological Survey Scientific Investigations Report 2011-5066, 44 p., https://pubs.er.usgs.gov/publication/sir20115066.

Johnson, T.D., 2005, Predicting residential irrigation amounts using satellite remote sensing in Los Angeles, California, Master's thesis, San Diego State University, 73 p.

Johnson, T.D., and Belitz, Kenneth, 2012, A remote sensing approach for estimating the location and rate of urban irrigation in semi-arid climates: Journal of Hydrology, v. 414-415, p. 86-98, http://dx.doi.org/10.1016/j.jhydrol.2011.10.016.

Los Angeles County Department of Public Works, Water Resources Division, 2006, Hydrology manual. Appendix D, Proportion Impervious Data. Digital polygon dataset.

Maidment, D.R. (ed), 1993, Handbook of Hydrology: McGraw-Hill, Inc., p. 7.5.

Maidment, D.R. (ed), 2002, Arc Hydro: GIS for water resources: Redlands, California, ESRI Press.

Markstrom, S.L., Niswonger, R.G., Regan, R.S., Prudic, D.E., and Barlow, P.M., 2008, GSFLOW-Coupled ground-water and surface-water flow model based on the integration of the Precipitation-Runoff Modeling System (PRMS) and the Modular Ground-Water Flow Model (MODFLOW-2005): U.S. Geological Survey Techniques and Methods 6-D1, 240 p., https://pubs.er.usgs.gov/publication/tm6D1.

Maxey, G.B., and Eakin, T.E., 1949, Ground water in White River Valley, White Pine, NYE, and Lincoln counties, Nevada: State of Nevada, Office of the State Engineer, in cooperation with the U.S. Department of the Interior, Geological Survey, 59 p., http://forestry.state.nv.us/hearings/ past/springetal/browseabledocs/exhibits/snwa\%20exhibits/ snwa_exh_290_maxey\%20and\%20eakin,\%201949.pdf.

Mayer, P.W., DeOreo, W.B., Opitz, E.M., Kiefer, J.C., Davis, W.Y., Dziegielewski, Benedykt, Nelson, J.O., 1999, Residential end uses of water: American Water Works Association Research Foundation, Denver, Colorado, 310 p., http://www.waterrf.org/publicreportlibrary/ rfr90781_1999_241a.pdf.

Milesi, C., Running, S.W., Elvidge, C.D., Dietz, J.B., Tuttle, B.T., and Nemani, R.R., 2005, Mapping and modeling the biogeochemical cycling of turf grasses in the United States: Environmental Management, v. 36, no. 3, p. 426-438, http://dx.doi.org/10.1007/s00267-004-0316-2.
Nash, J.E., and Sutcliffe, J.V., 1970, River flow forecasting through conceptual models part I-A discussion of principals: Journal of Hydrology, v. 10, no. 3, p. 282-290, http://dx.doi.org/10.1016/0022-1694(70)90255-6.

Nishikawa, Tracy, Izbicki, J.A., Hevesi, J.A., Stamos, C.L., and Martin, Peter, 2005, Evaluation of geohydrologic framework, recharge estimates and ground-water flow of the Joshua Tree area, San Bernardino County, California: U.S. Geological Survey Scientific Investigations Report 2004-5267, 127 p., https://pubs.er.usgs.gov/publication/sir20045267.

Reichard, E.G., Land, Michael, Crawford, S.M., Johnson, T.D., Everett, Rhett, Kulshan, T.V., Ponti,D.J., Halford, K.L., Johnson, T.A., Paybins, K.S., and Nishikawa, Tracy, 2003, Geohydrology, Geochemistry, and Ground-Water Simulation-Optimization of the Central and West Coast Basins, Los Angeles County, California: U.S. Geological Survey Water-Resources Investigations Report 2003-4065, 196 p., https://pubs.er.usgs.gov/publication/wri034065.

Rewis, D.L., Christensen, A.H., Matti, Jonathan, Hevesi, J.A., Nishikawa, Tracy, and Martin, Peter, 2006, Geology, ground-water hydrology, geochemistry, and ground-water simulation of the Beaumont and Banning storage units, San Gorgonio Pass area, Riverside County, California: U.S. Geological Survey Scientific Investigations Report 2006-5026, 191 p., https://pubs.er.usgs.gov/publication/sir20065026.

Sample, D.J., and Heaney, J.P., 2006, Integrated management of irrigation and urban storm-water infiltration: Journal of Water Resources Planning and Management, v. 132, no. 5, p. 362-373, http://dx.doi.org/10.1061/(ASCE)07339496(2006)132:5(362).

San Diego County Water Authority, 2001, A common need, with shared solutions, Annual report 2001: San Diego County Water Authority, San Diego, CA, 49 p., http://www. sdcwa.org/sites/default/files/files/publications/annual_2001. pdf.

Southern California Area Governments, 2005, Los Angeles County land use, Digital polygon dataset.

U.S. Department of Agriculture, 1994, State Soil Geographic (STATSGO) Data Base-Data use information: Natural Resource Conservation Service, Miscellaneous Publication no. 1492: Soil Survey Staff, Natural Resources Conservation Service, United States Department of Agriculture. U.S. General Soil Map (STATSGO) for California, accessed December 12, 2001, at http://sdmdataaccess.nrcs.usda.gov/. 
U.S. Geological Survey, 2001, The national map seamless server database, http://www.webgis.com/usgsseam.html.

U.S. Geological Survey, 2005, National Land Cover Database-Zone 60 Imperviousness layer: U.S. Geological Survey data available on the World Wide Web, accessed May 16, 2005, at http://seamless.usgs.gov.

U.S. Geological Survey, 2008, Documentation of computer program INFIL3.0-A distributed-parameter watershed model to estimate net infiltration below the root zone: U.S. Geological Survey Scientific Investigation Report 2008-5006, 98 p.

http://water.usgs.gov/nrp/gwsoftware/Infil/Infil.html.

Water Replenishment District of Southern California, 2013, Engineering Survey and Report, Updated May 10, 2013, 70 p., http://www.wrd.org/WRD_ESR2013_May4_Final_ Report_web.pdf.

Westenbroek, S.M., Kelson, V.A., Dripps, W.R., Hunt, R.J., and Bradbury, K.R., 2010, SWB-A modified ThornthwaiteMather Soil-Water-Balance code for estimating groundwater recharge: U.S.Geological Survey Techniques and Methods 6-A31, 52 p., https://pubs.er.usgs.gov/publication/tm6A31.

Woolfenden, L.R., and Nishikawa, Tracy, eds., 2014, Simulation of groundwater and surface-water resources of the Santa Rosa Plain watershed, Sonoma County, California: U.S. Geological Survey Scientific Investigations Report 2014-5052, 258 p., http://dx.doi.org/10.3133/sir20145052. 

Appendix 1 


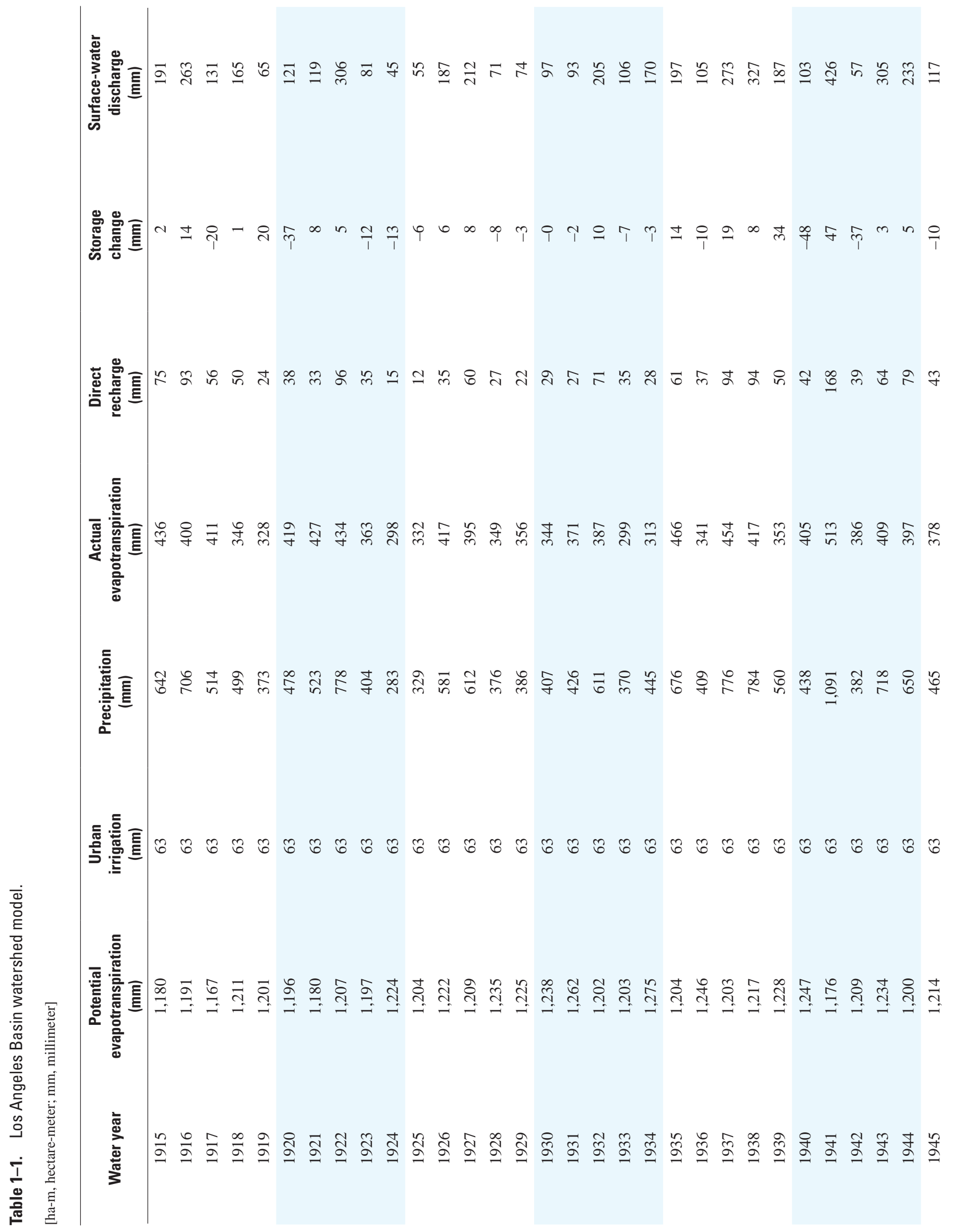




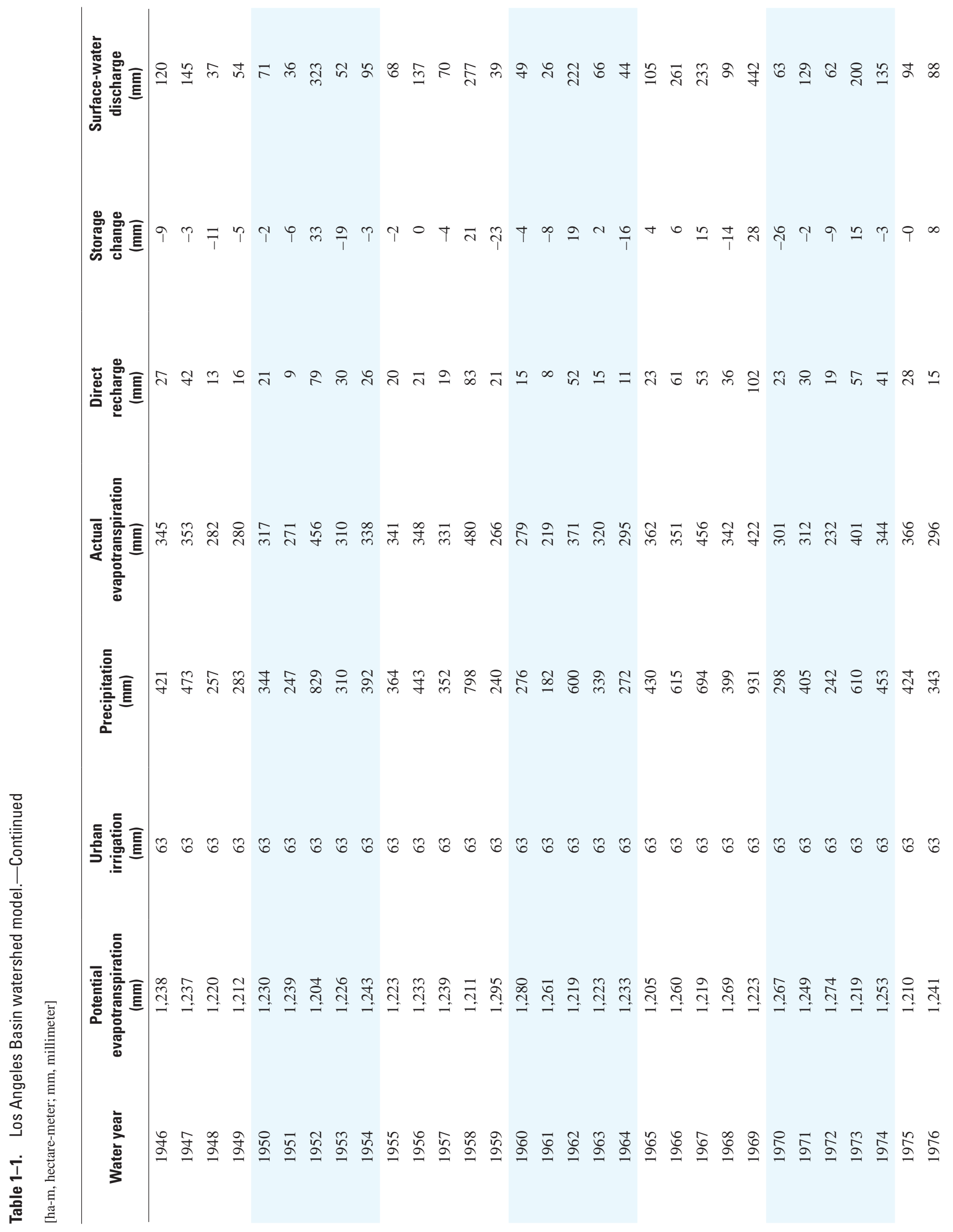




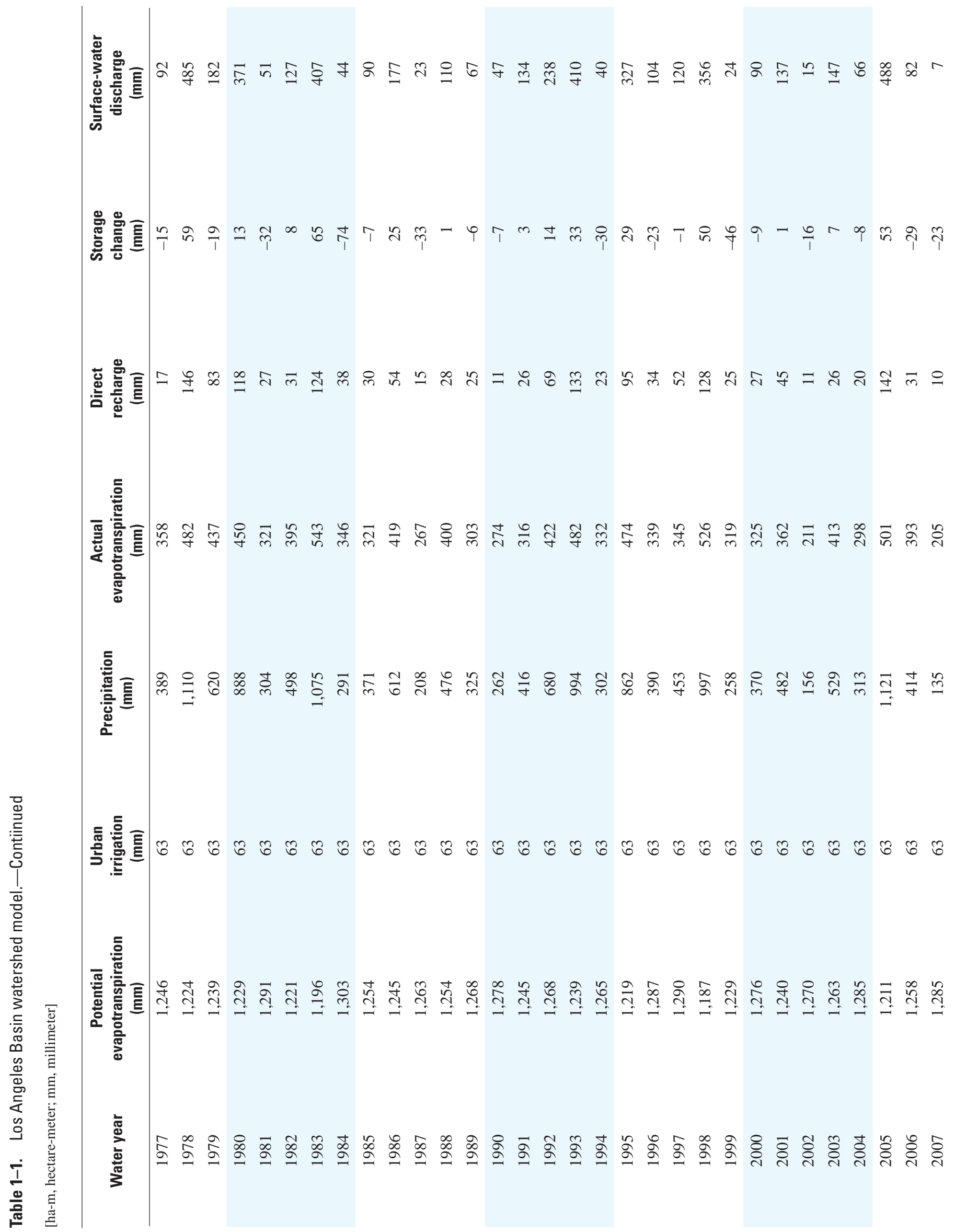




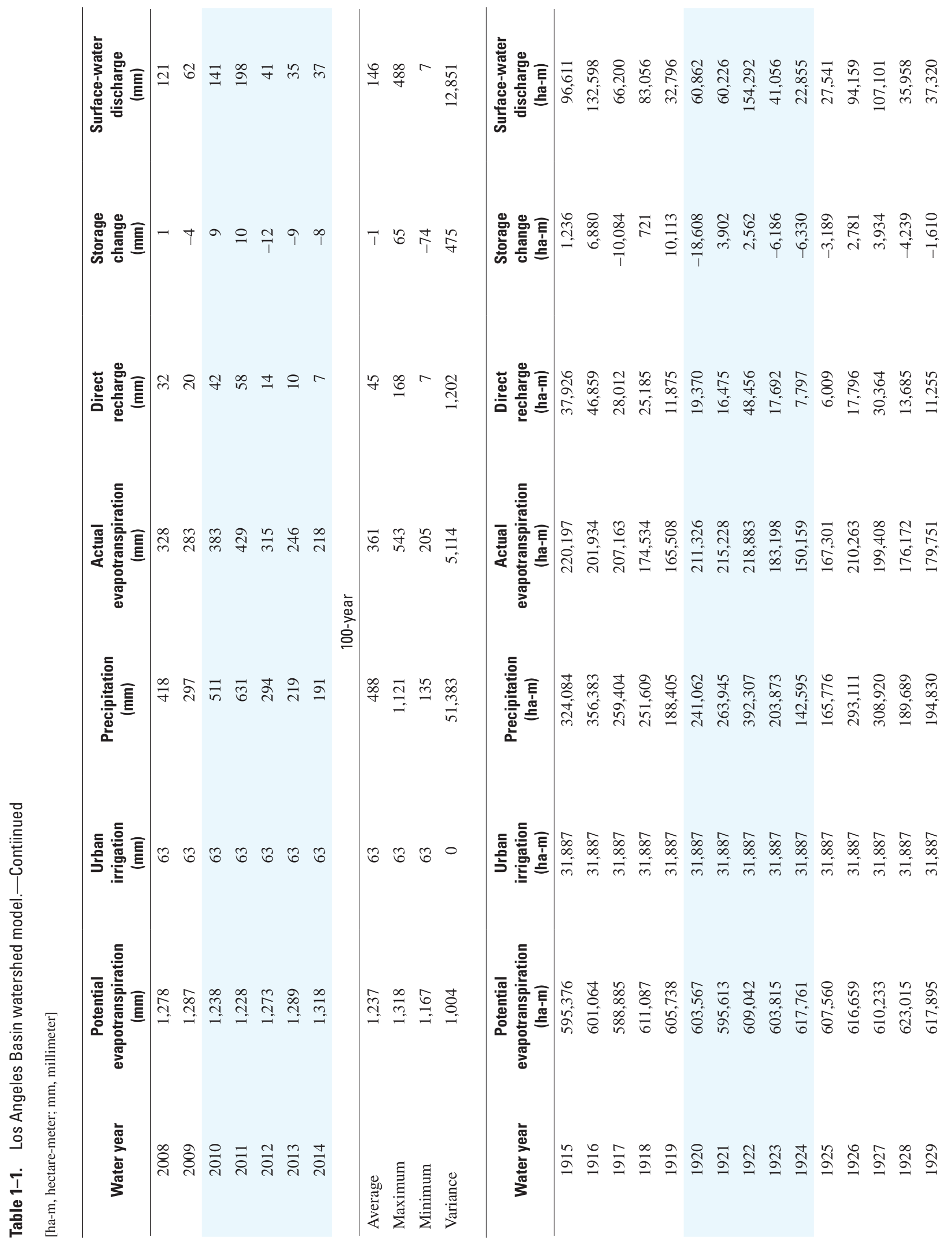




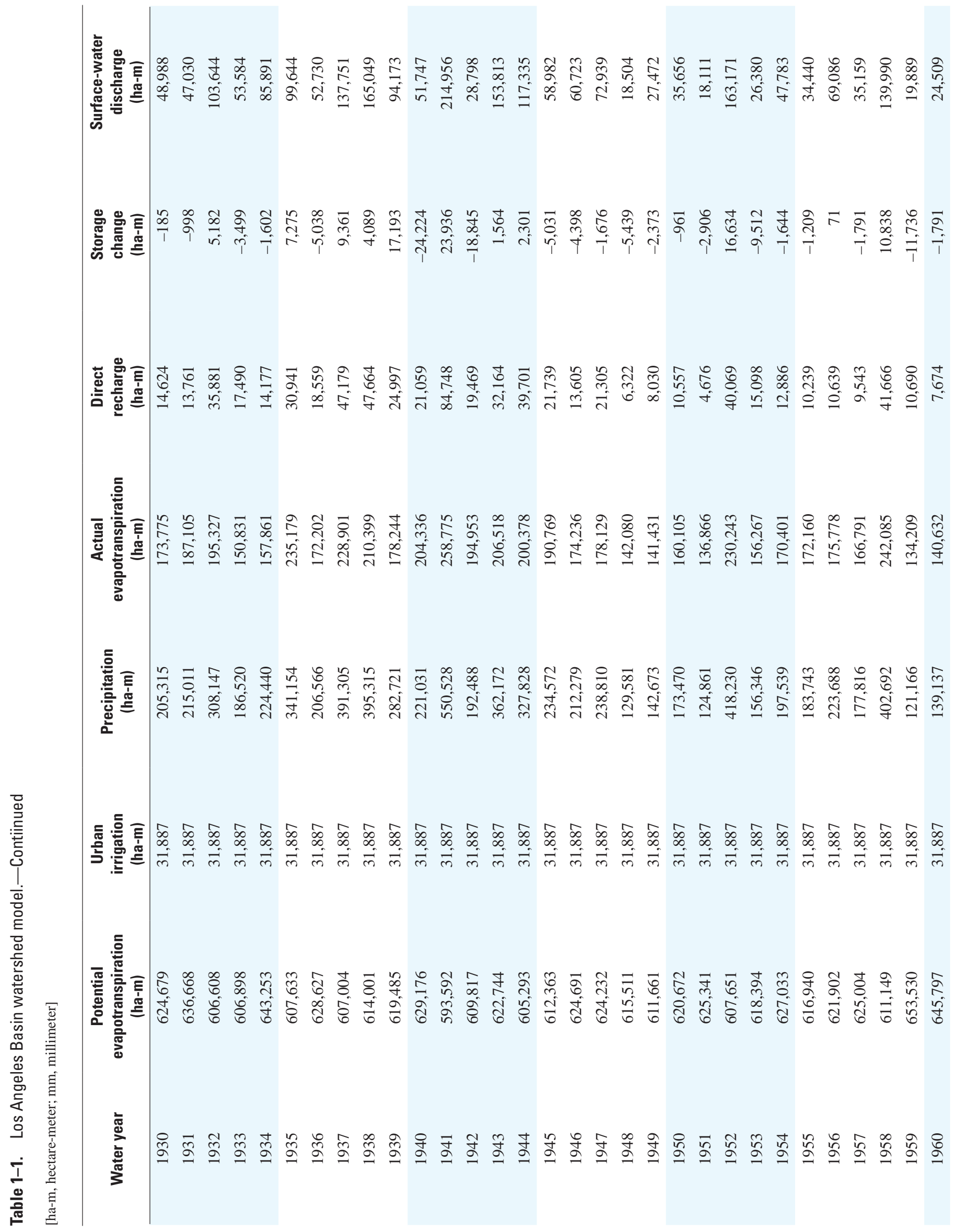




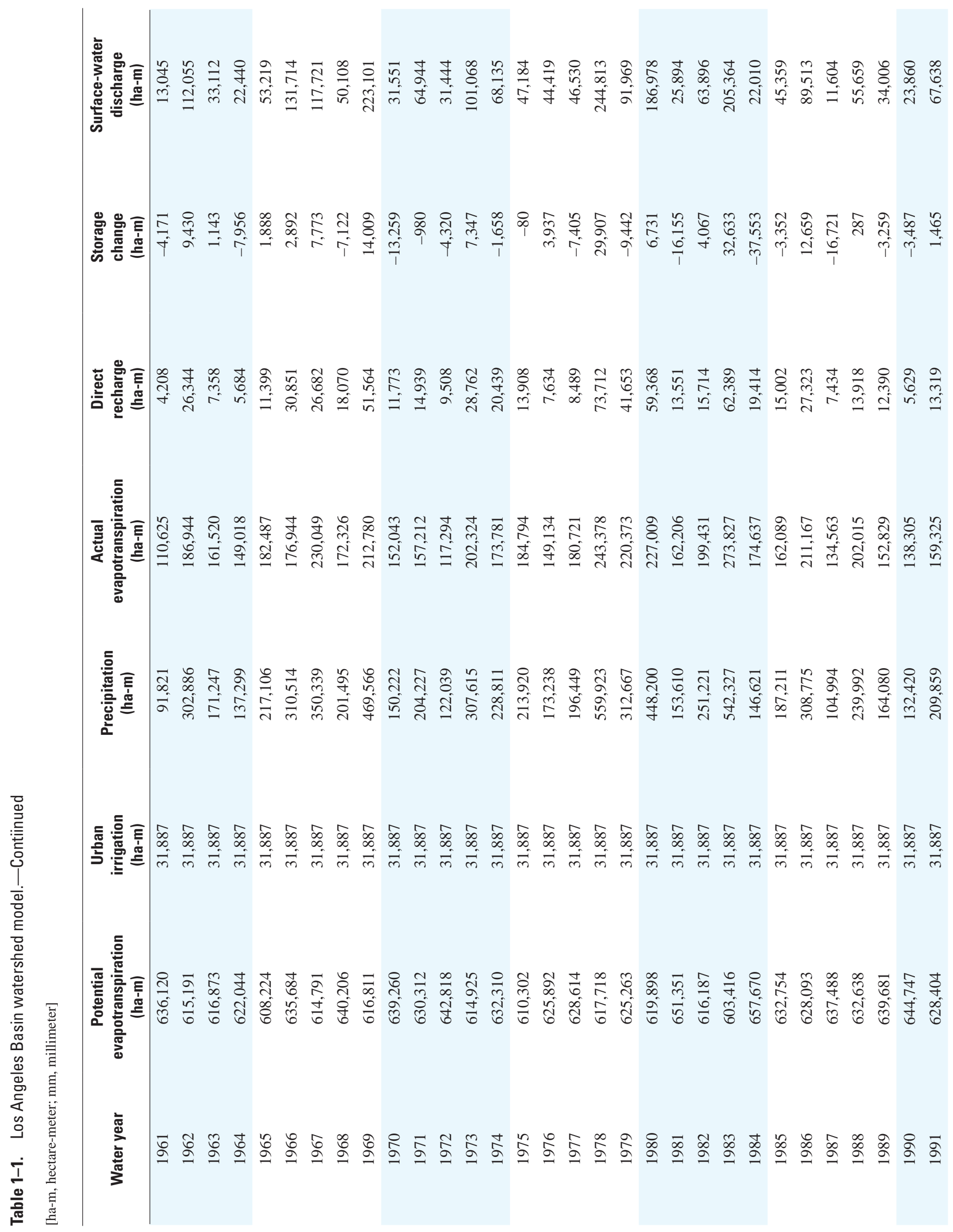




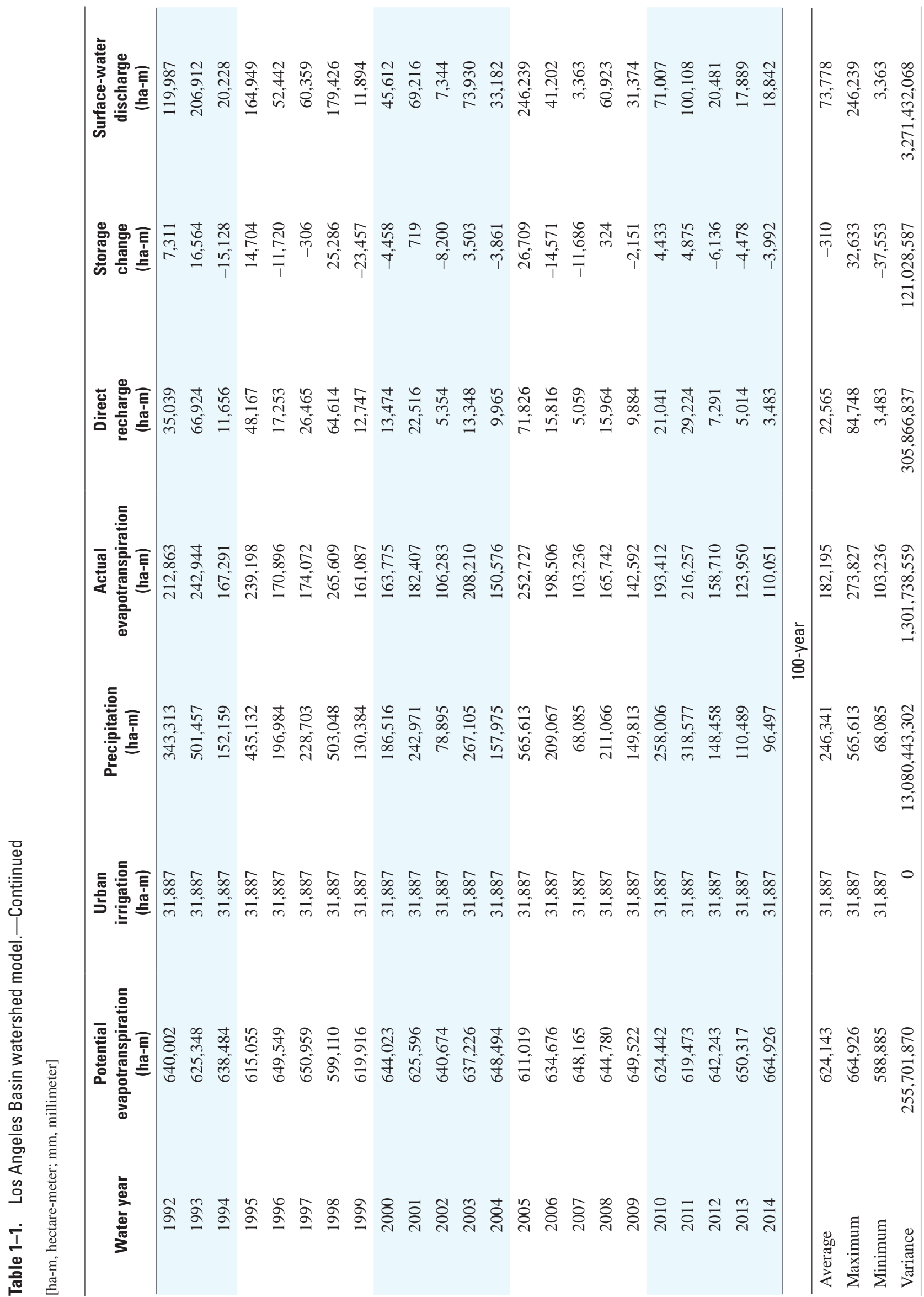


Appendix 2 


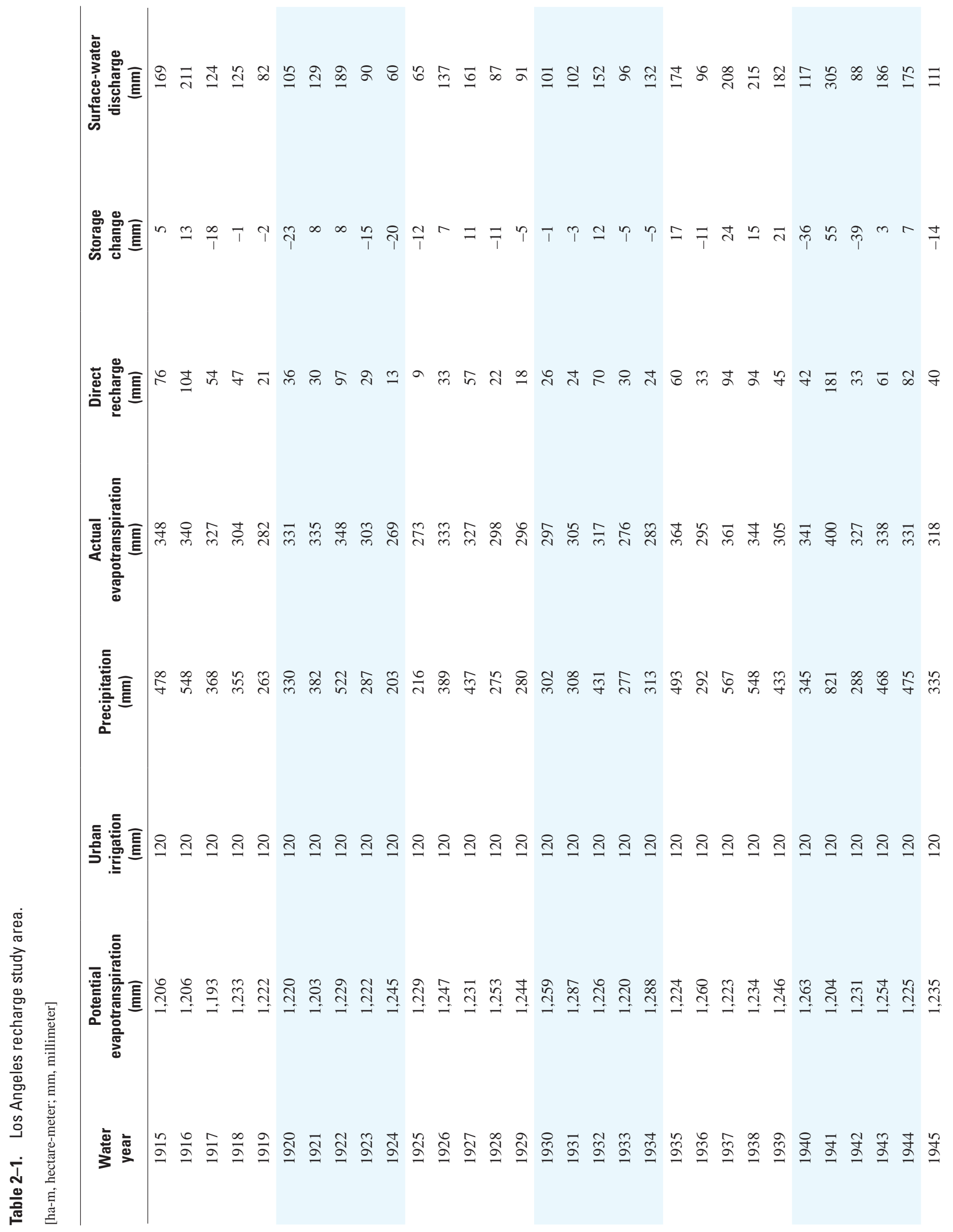




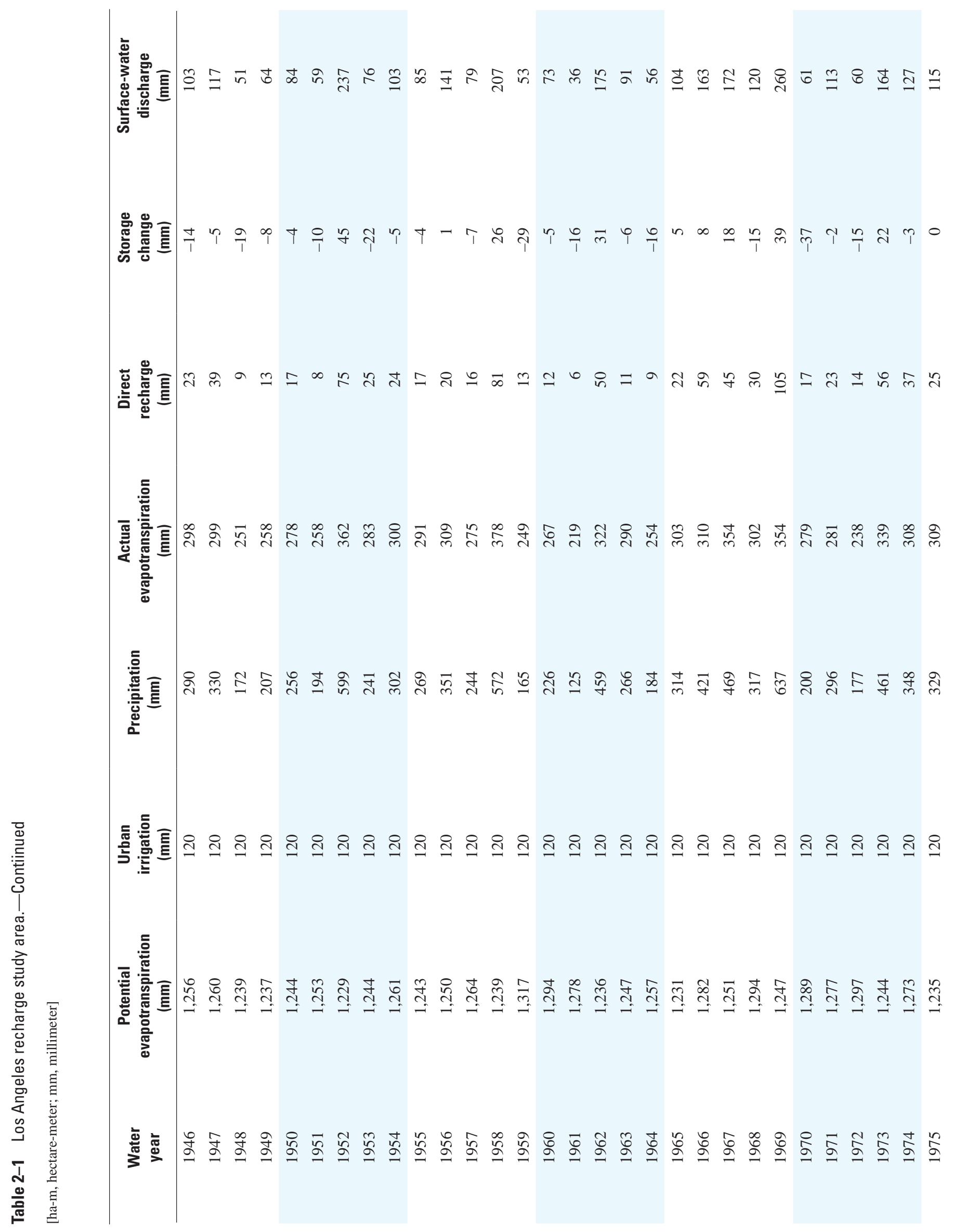




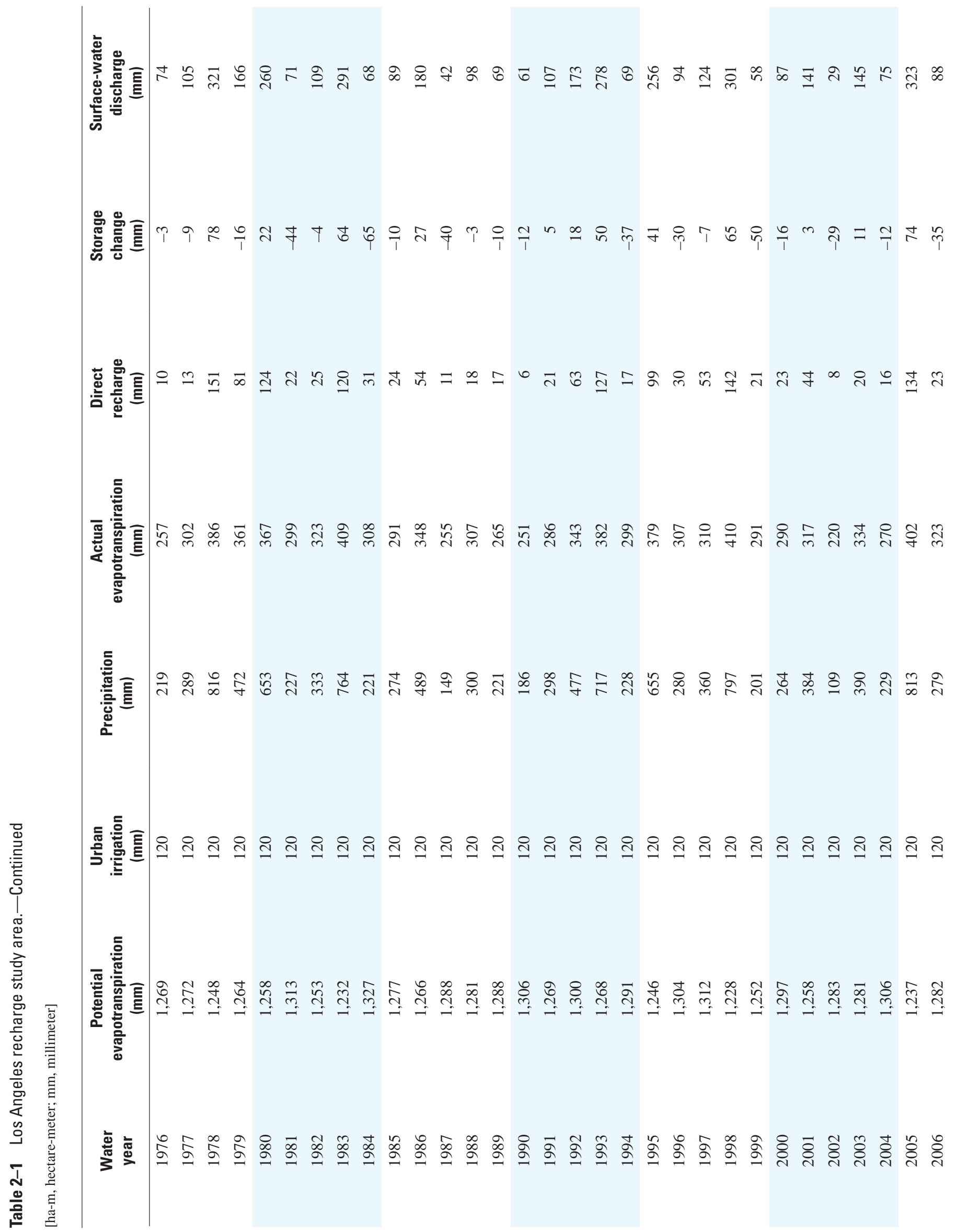




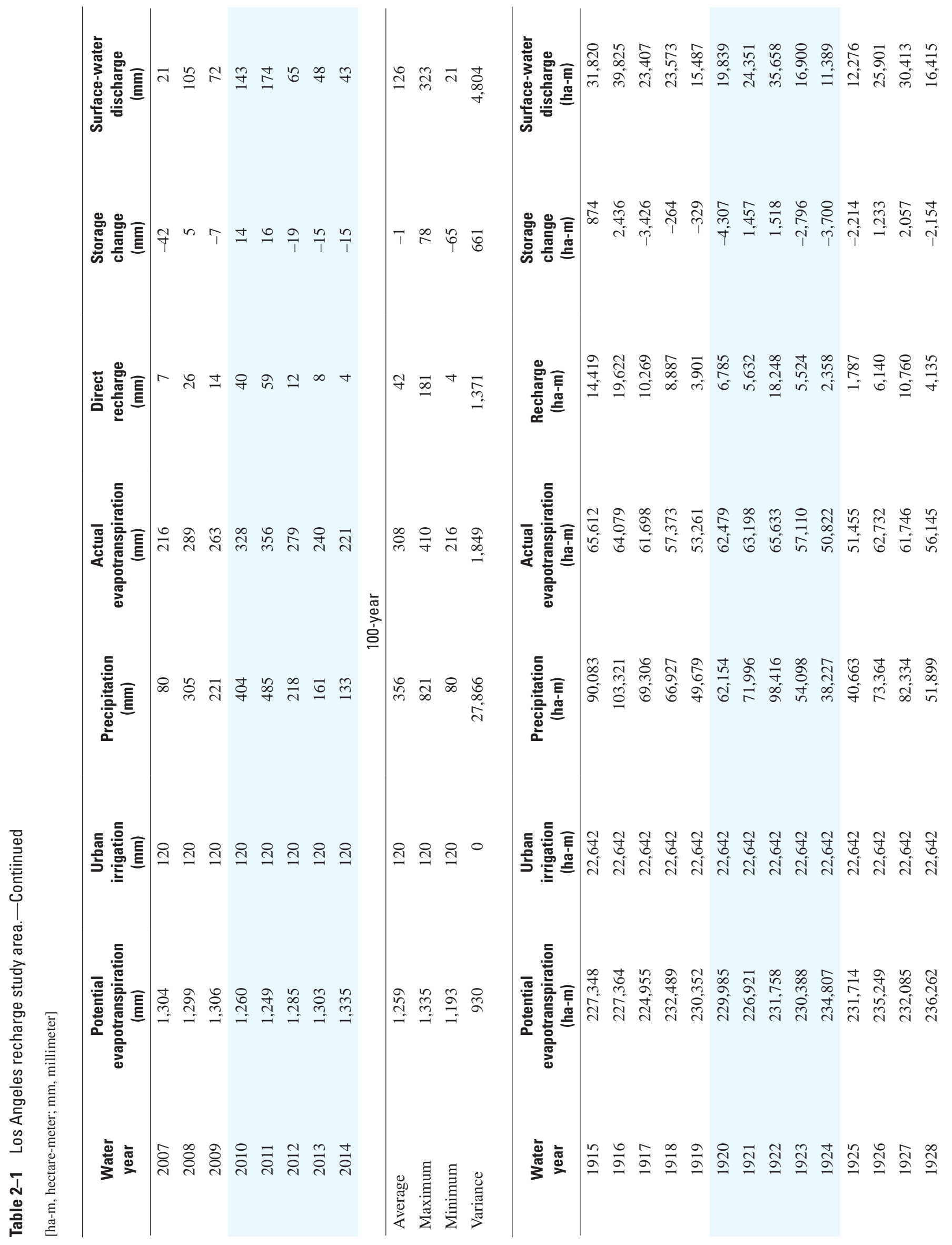




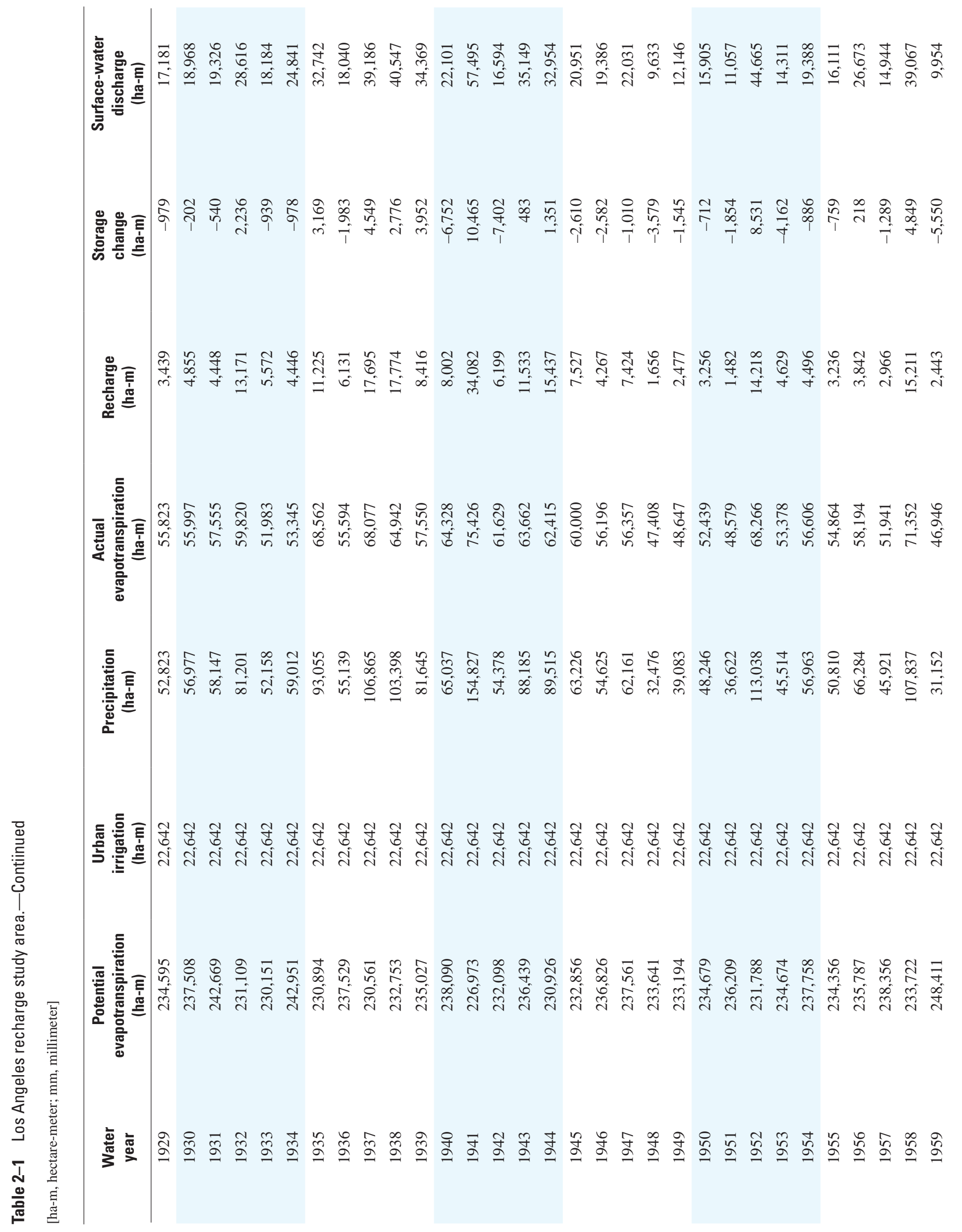




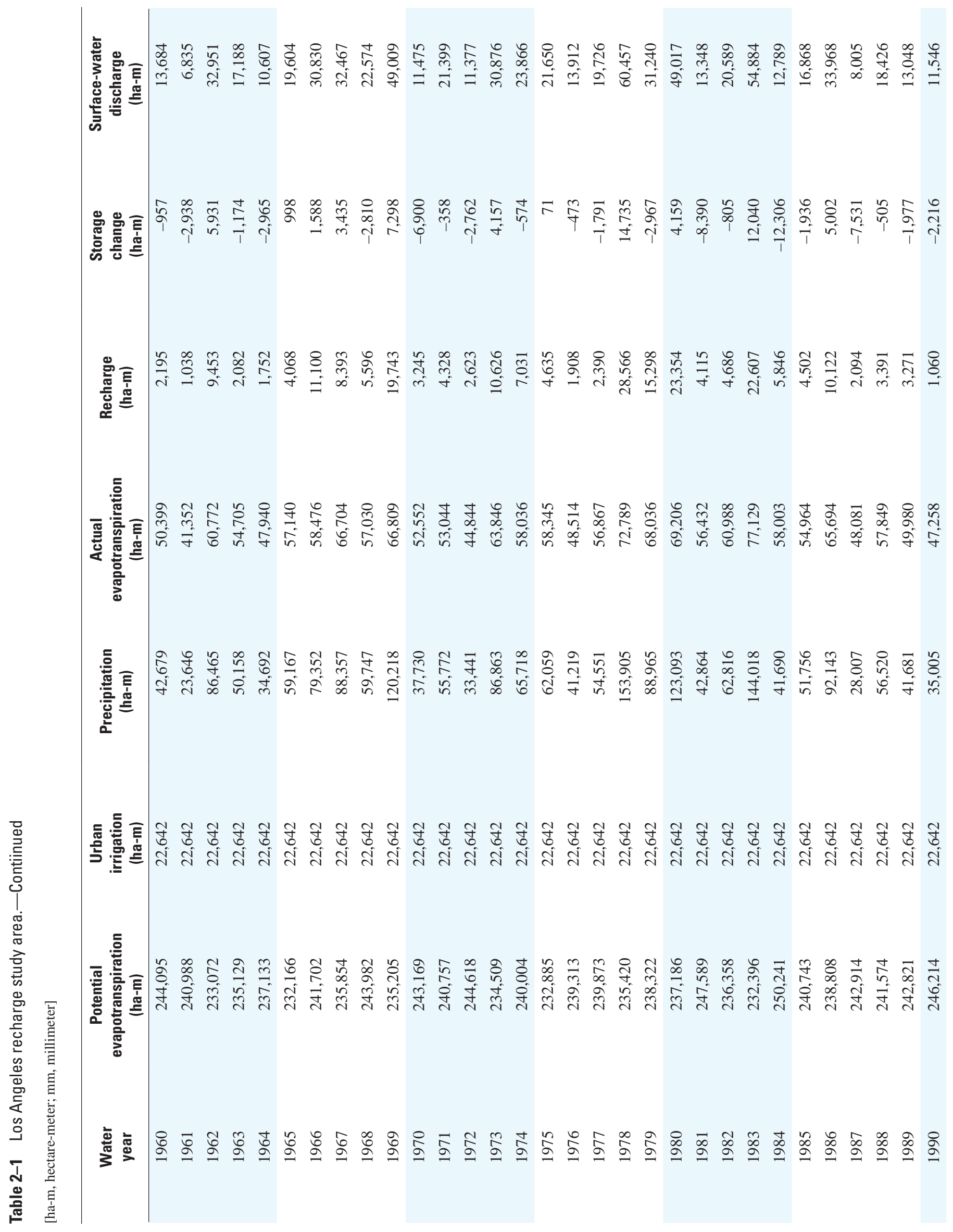




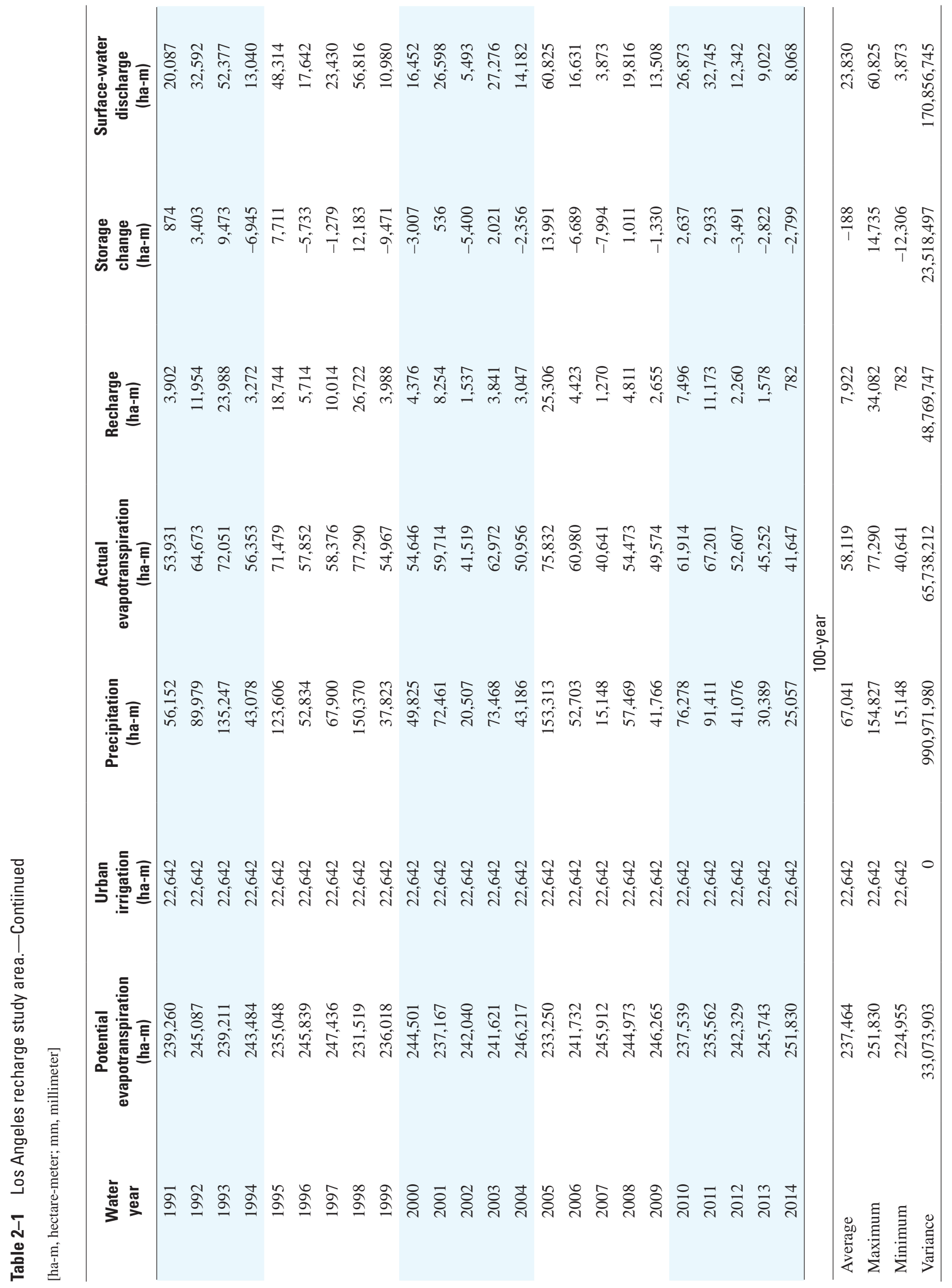


Appendix 3 


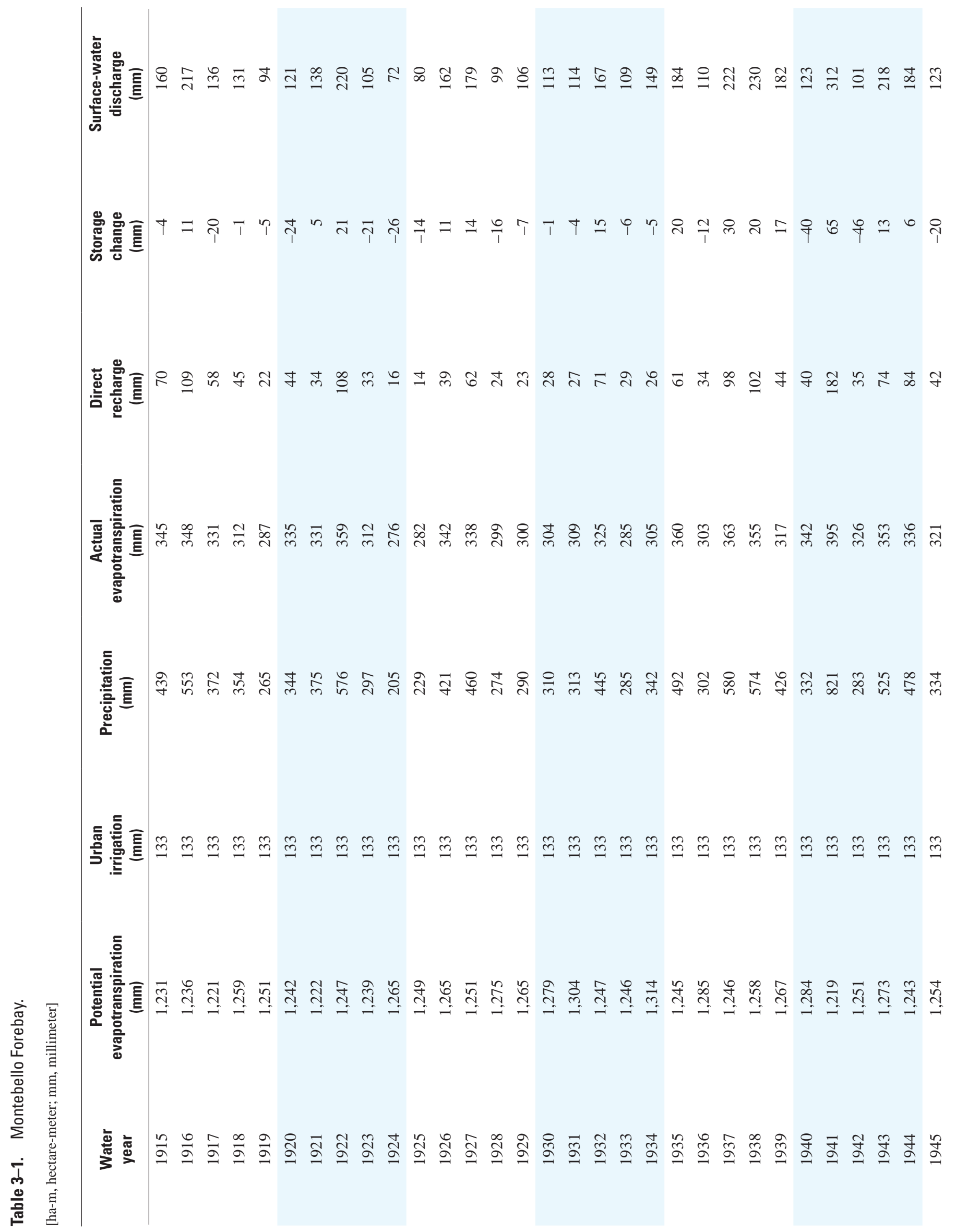




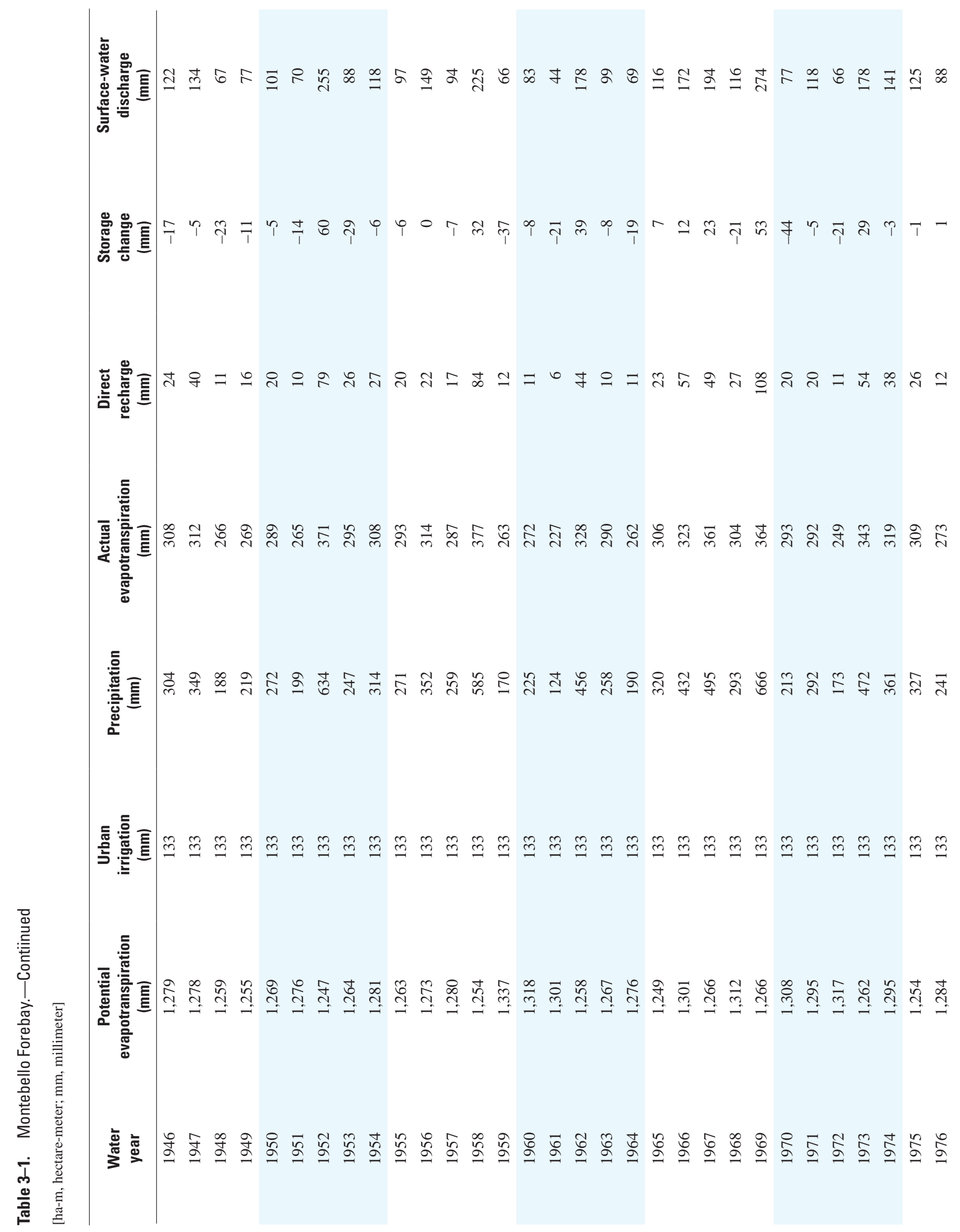




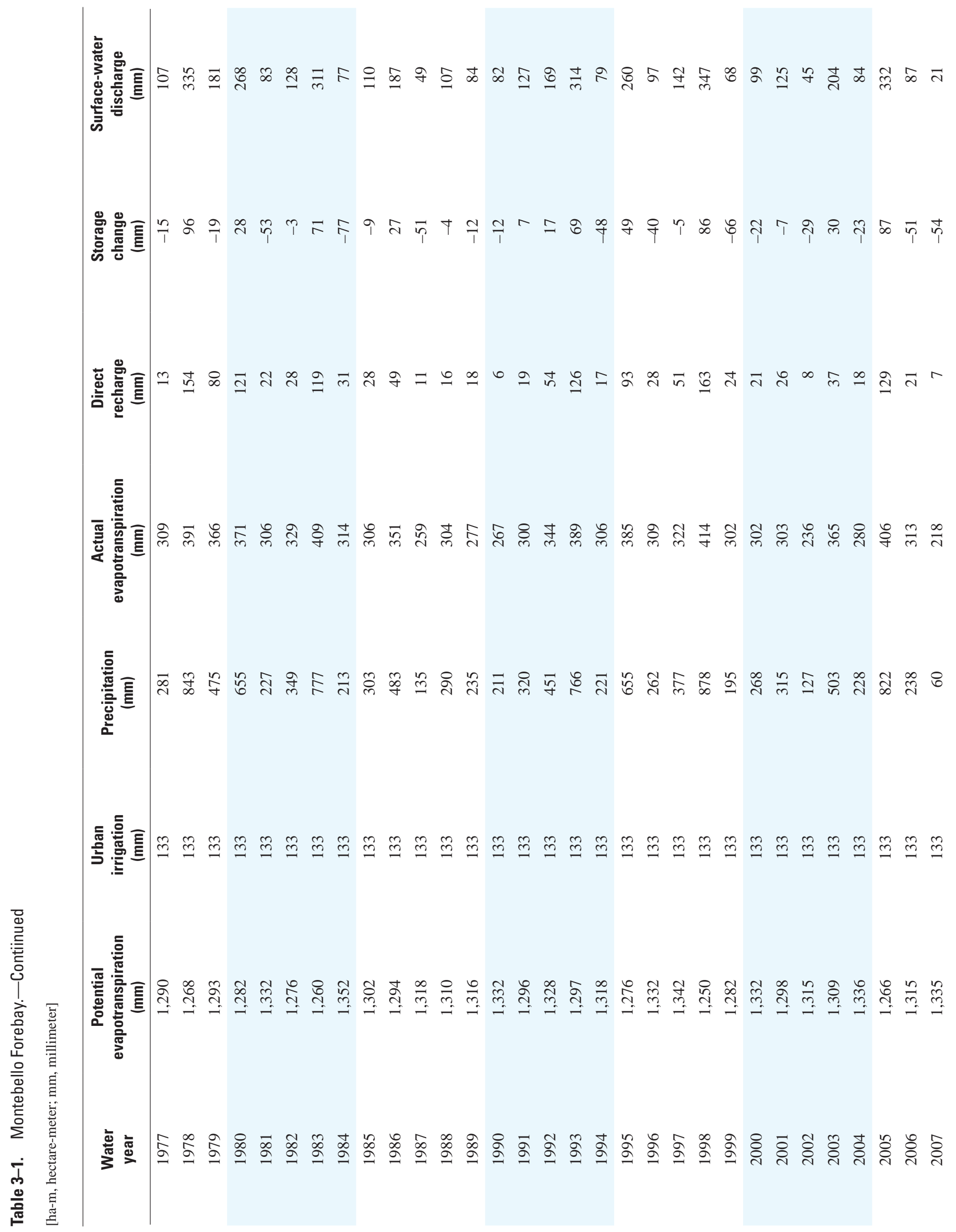




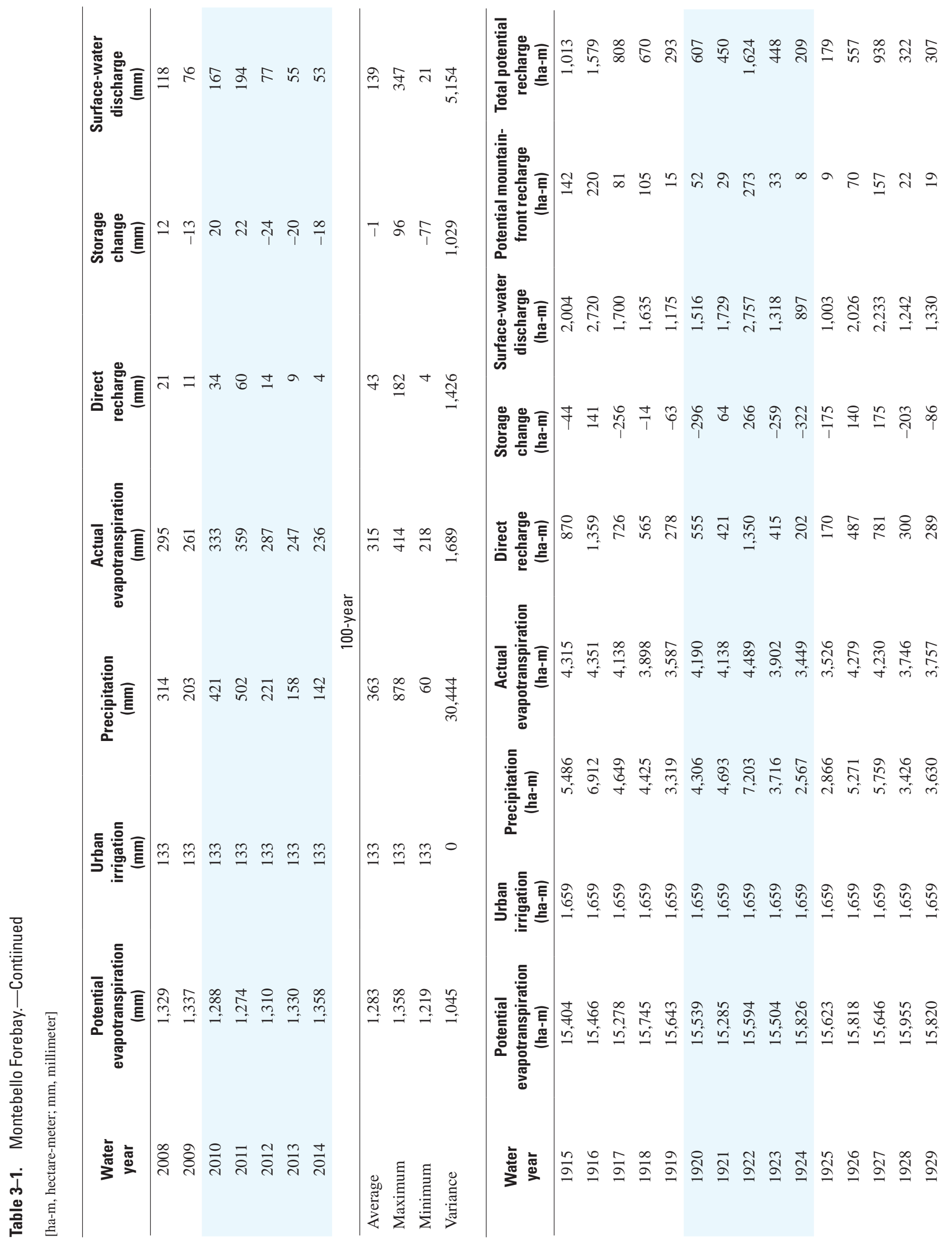




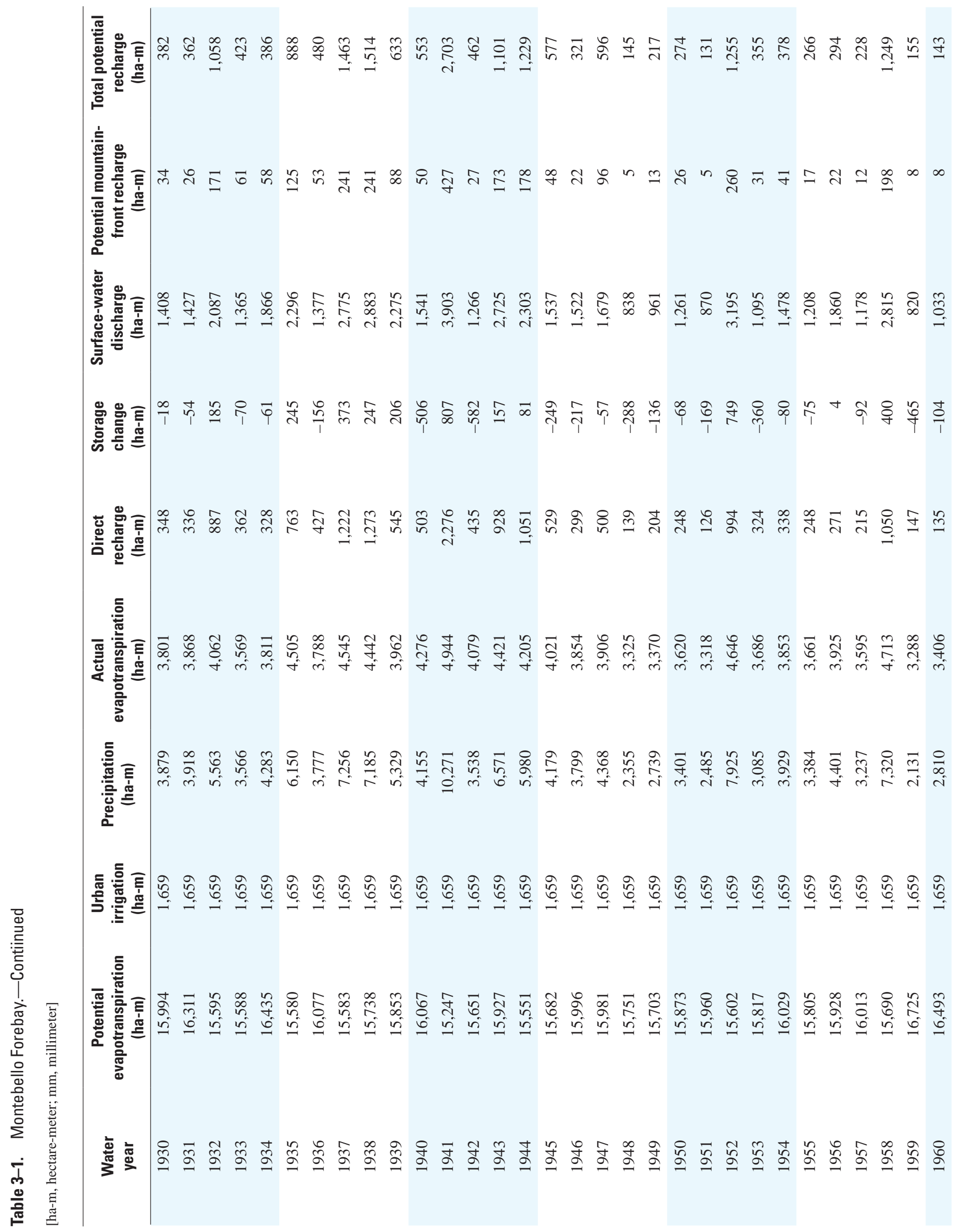




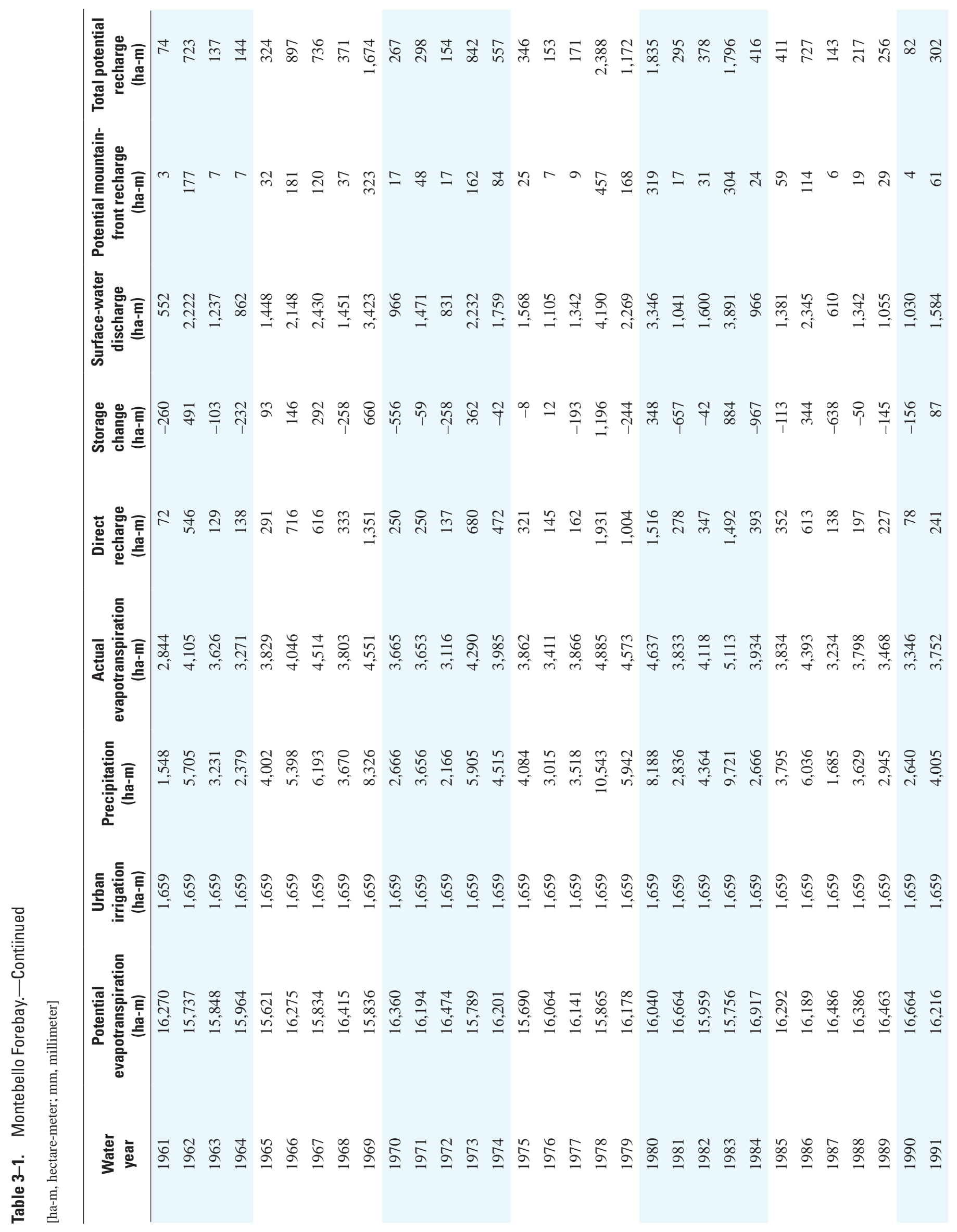




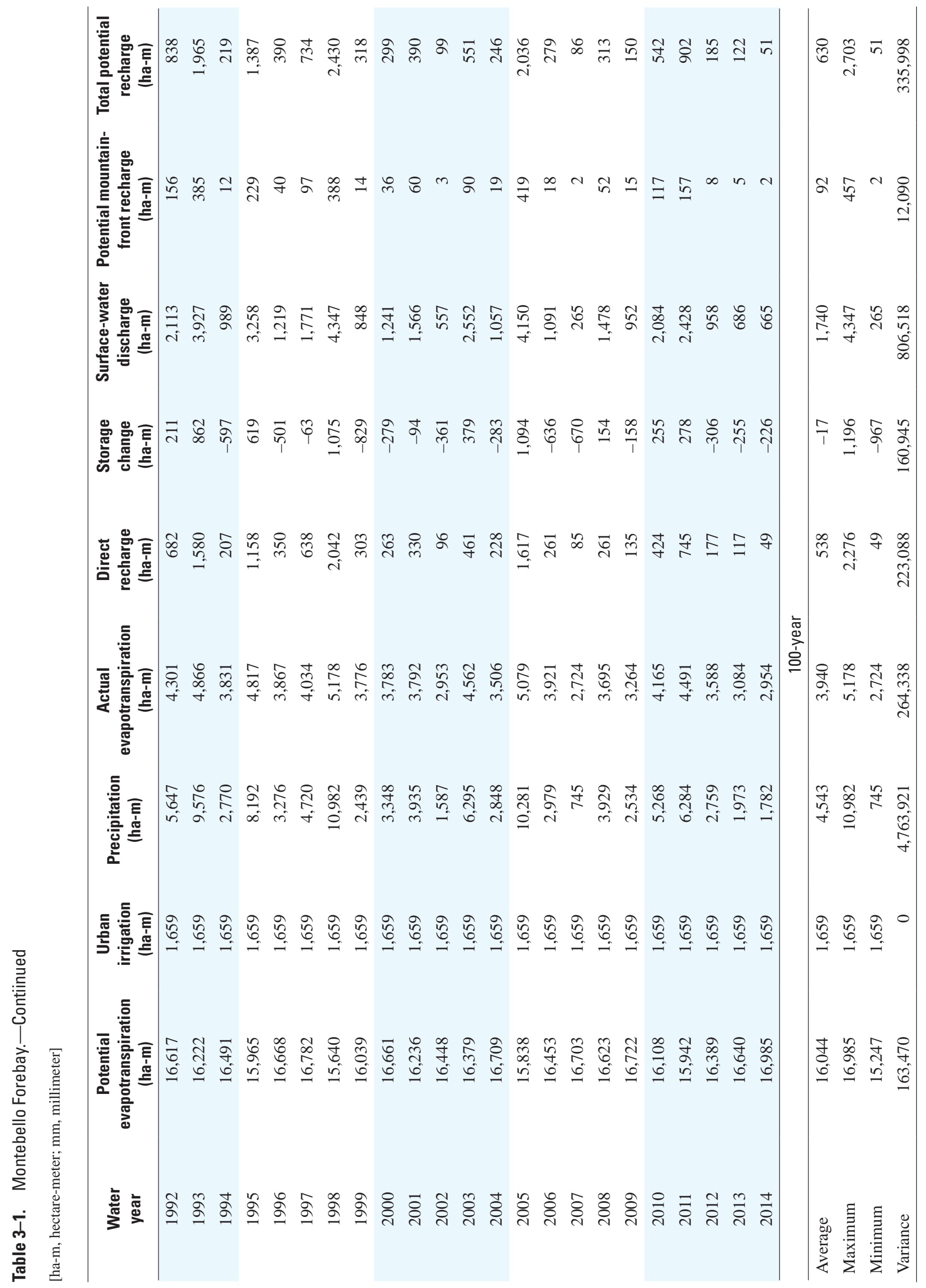




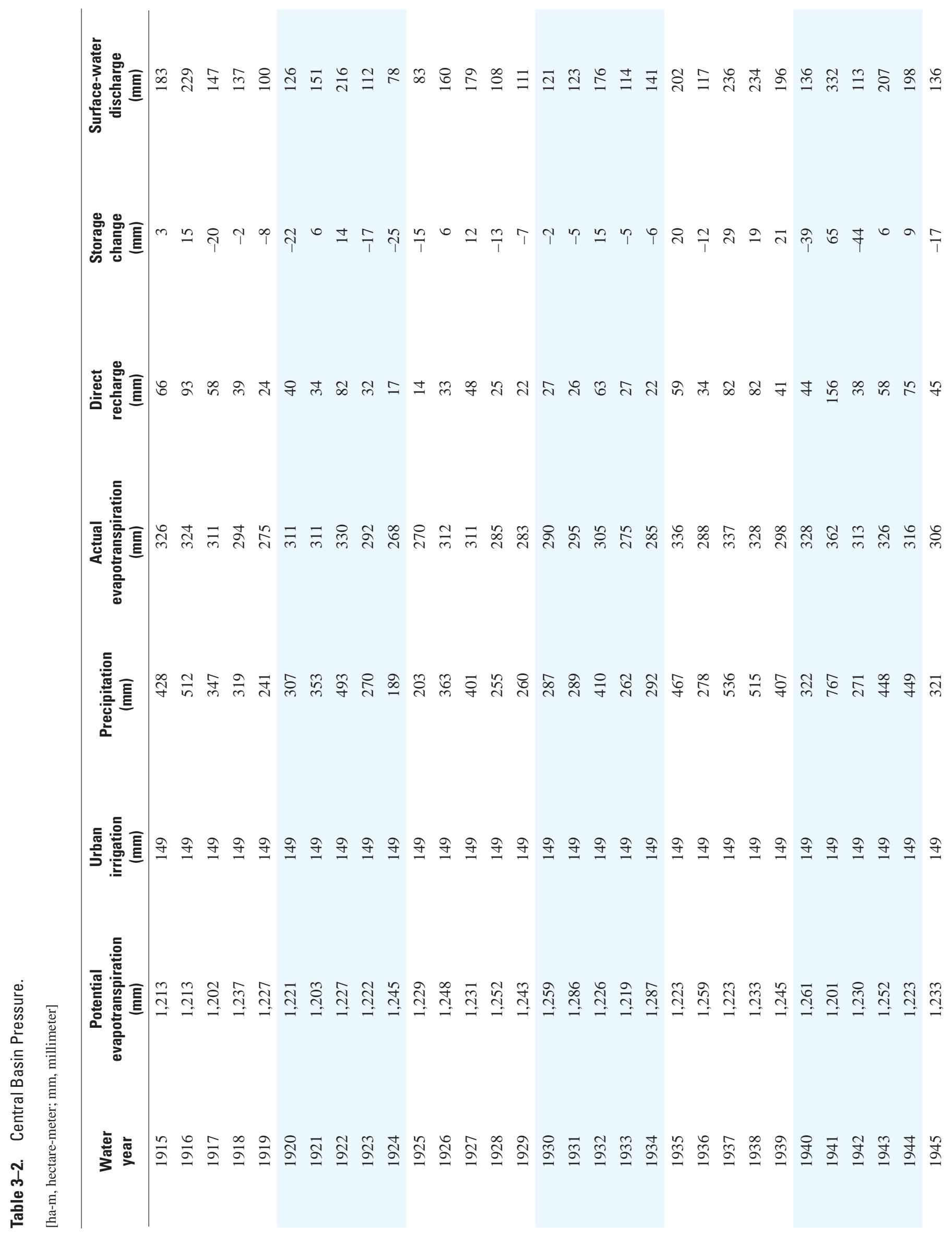




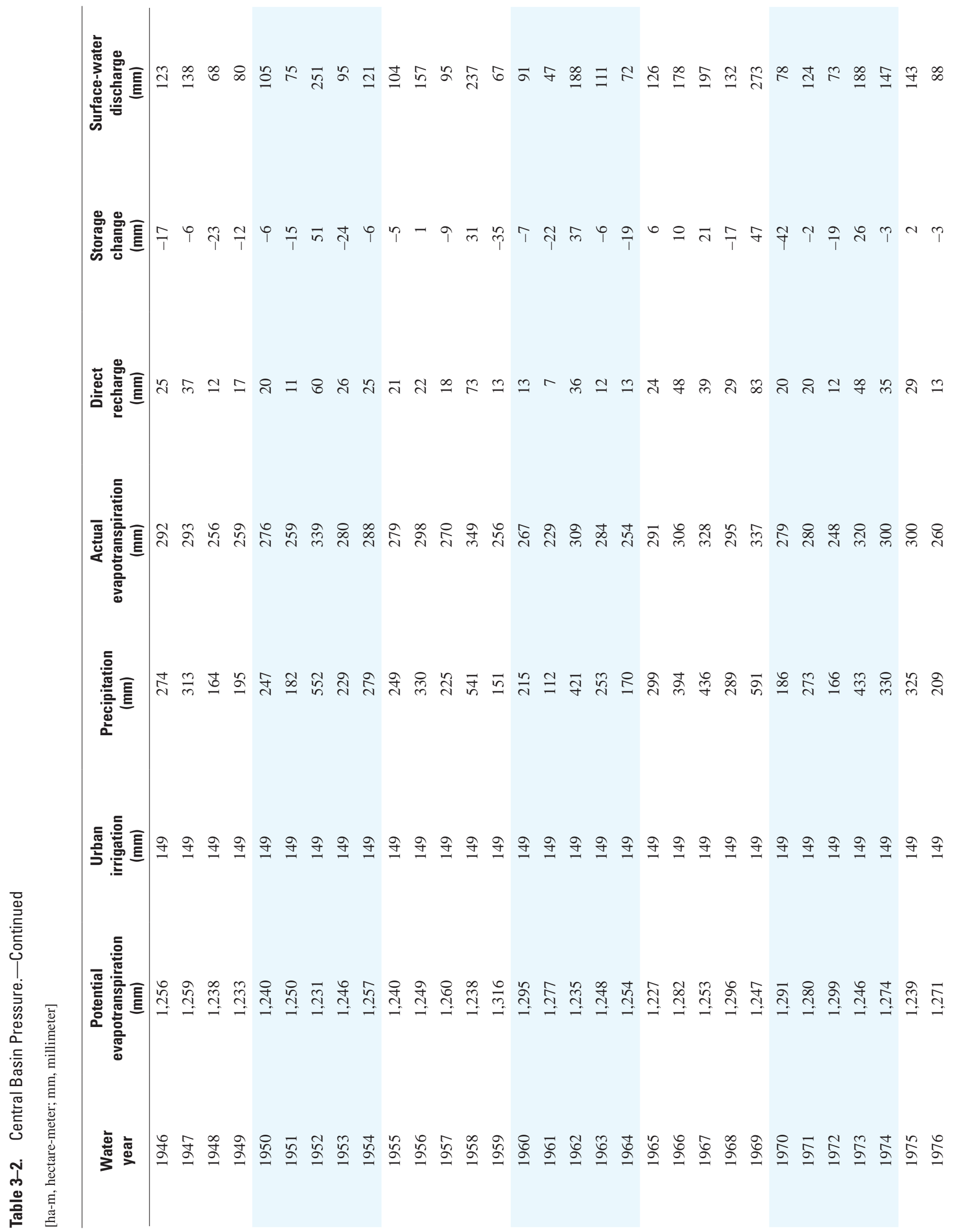




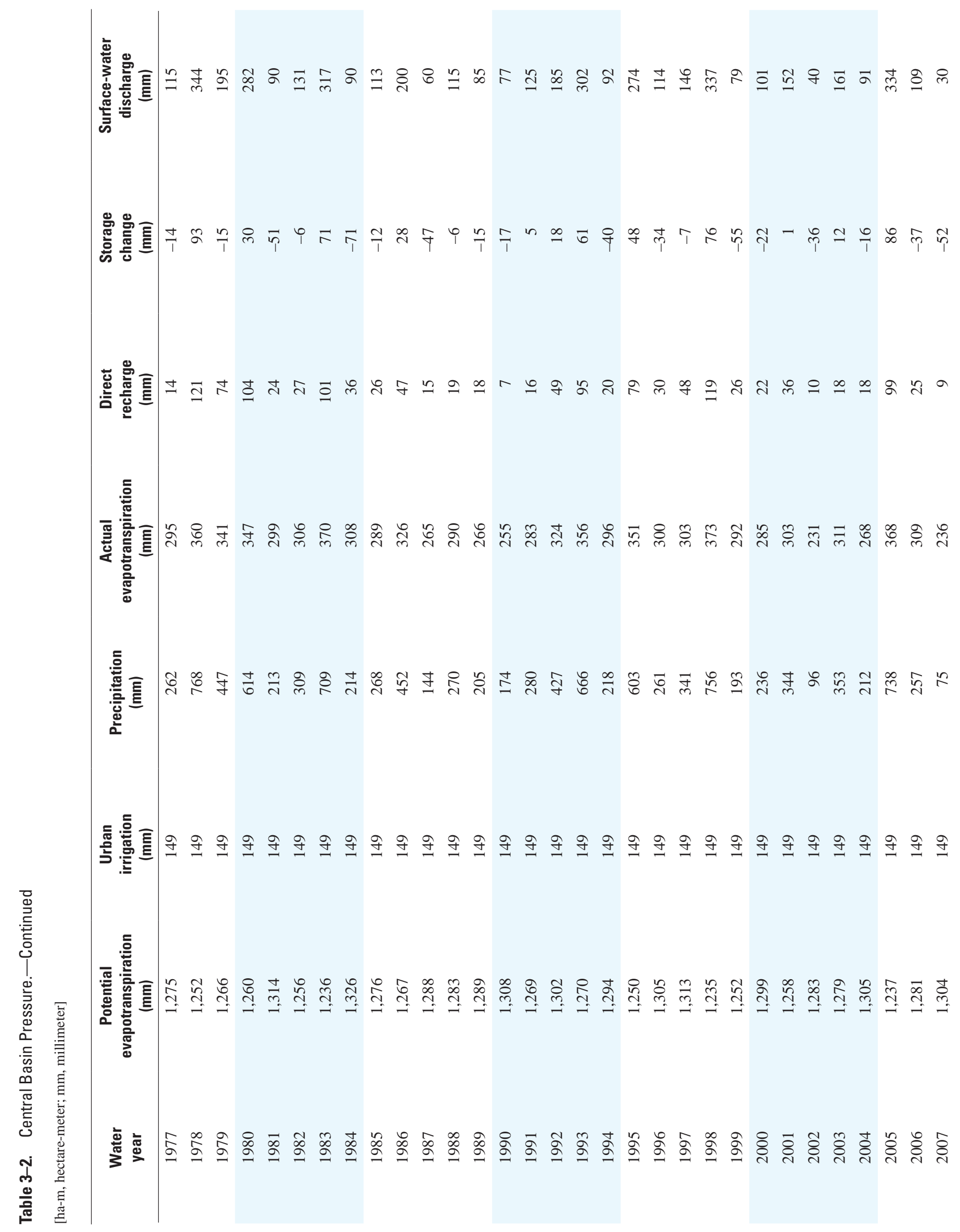




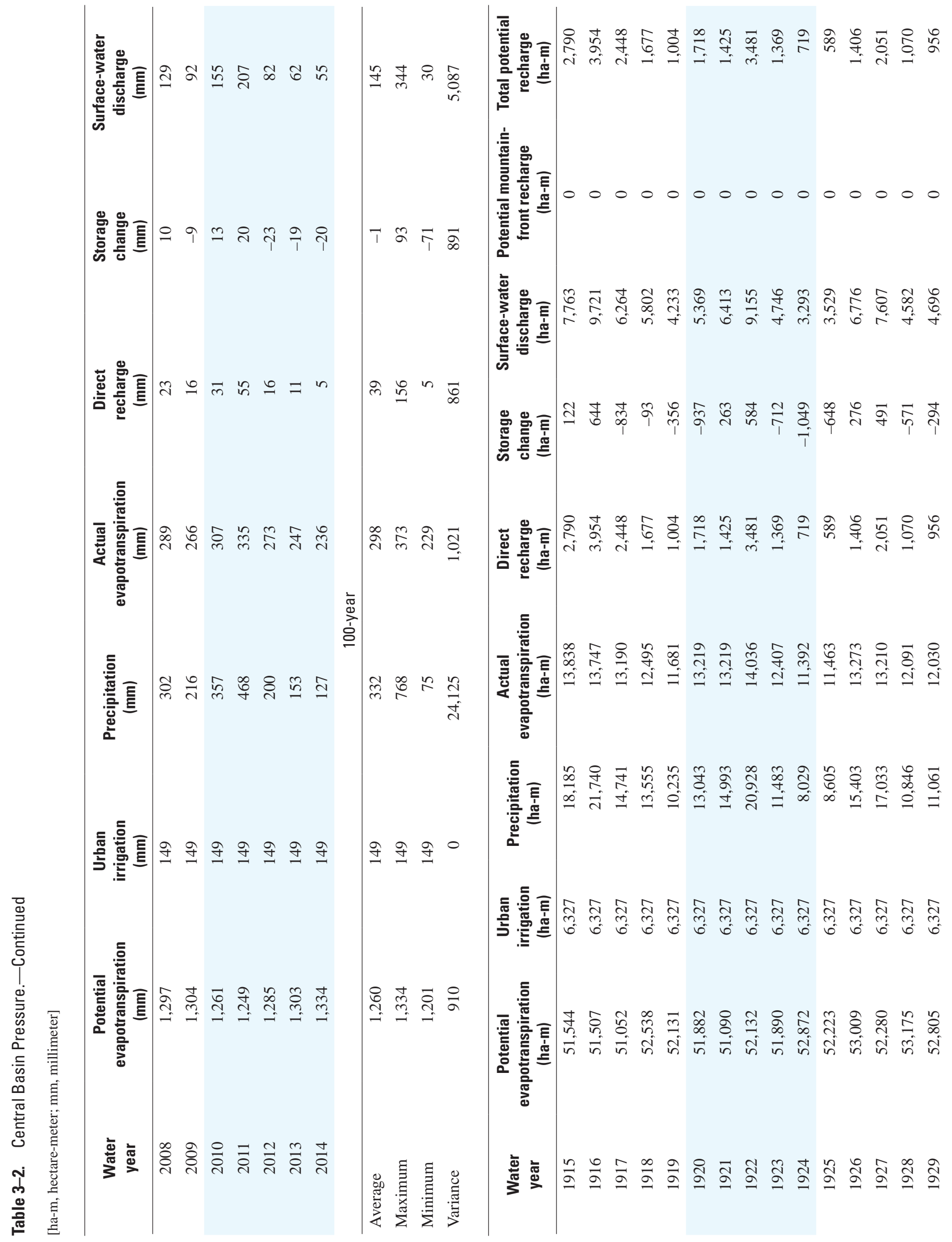




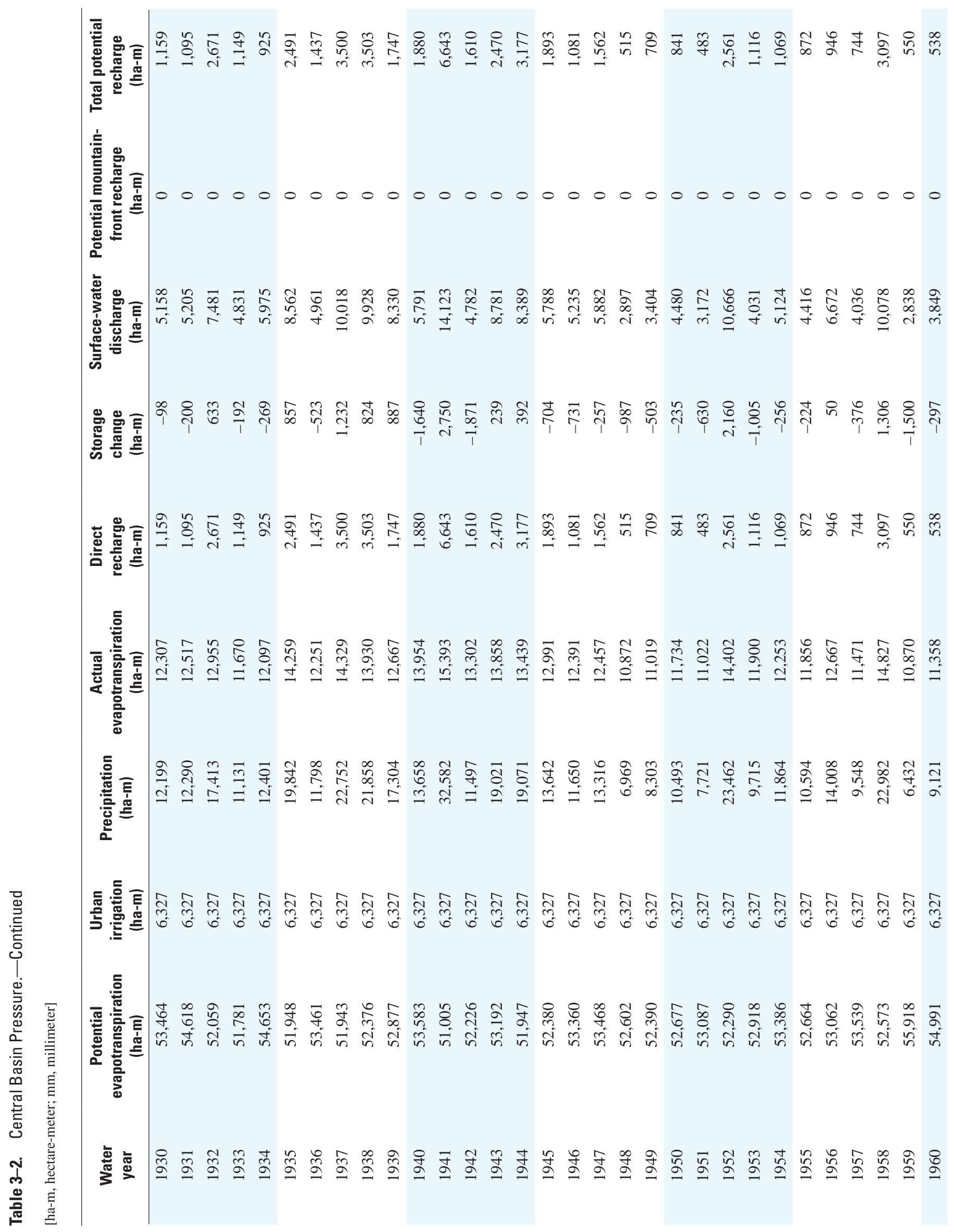




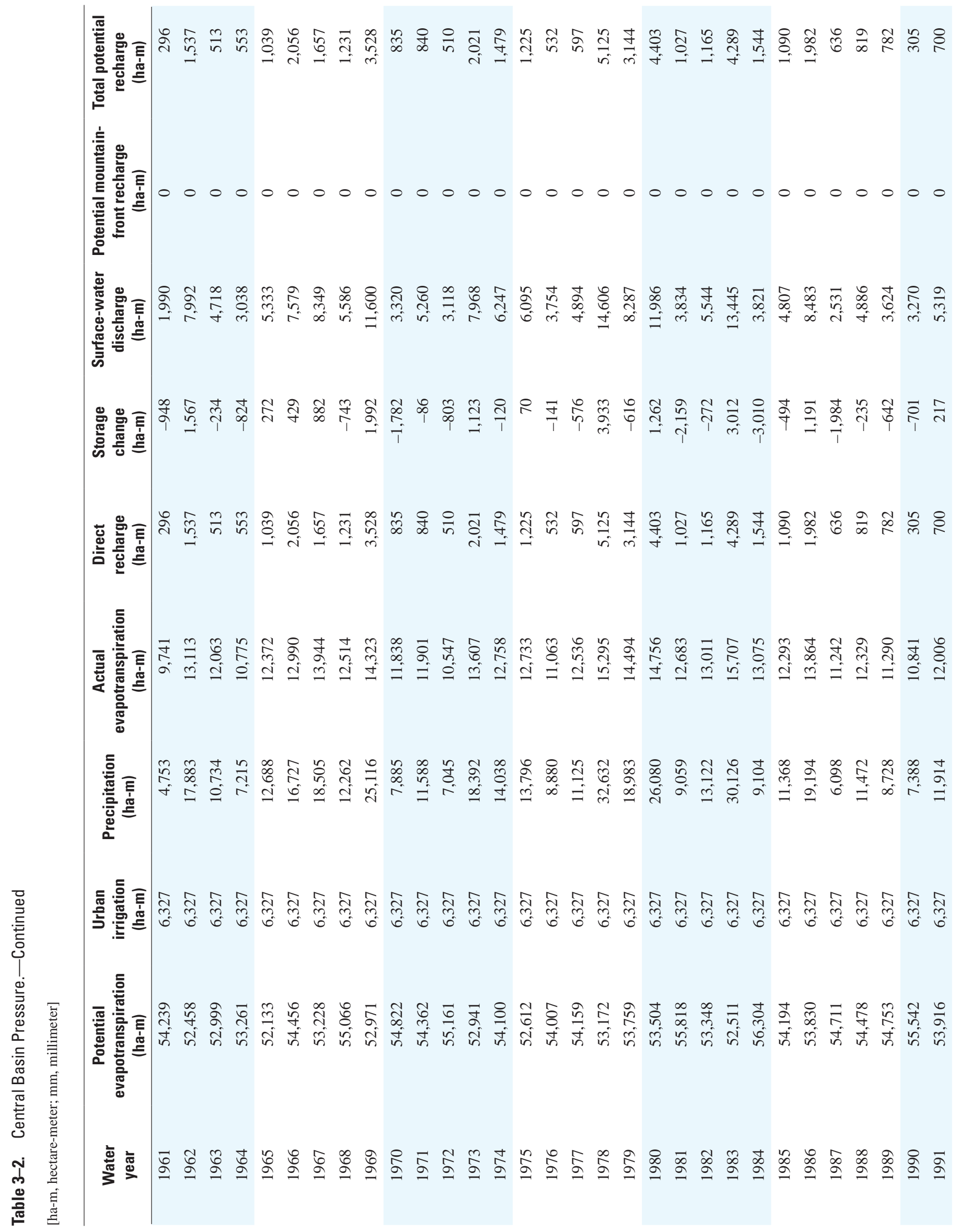




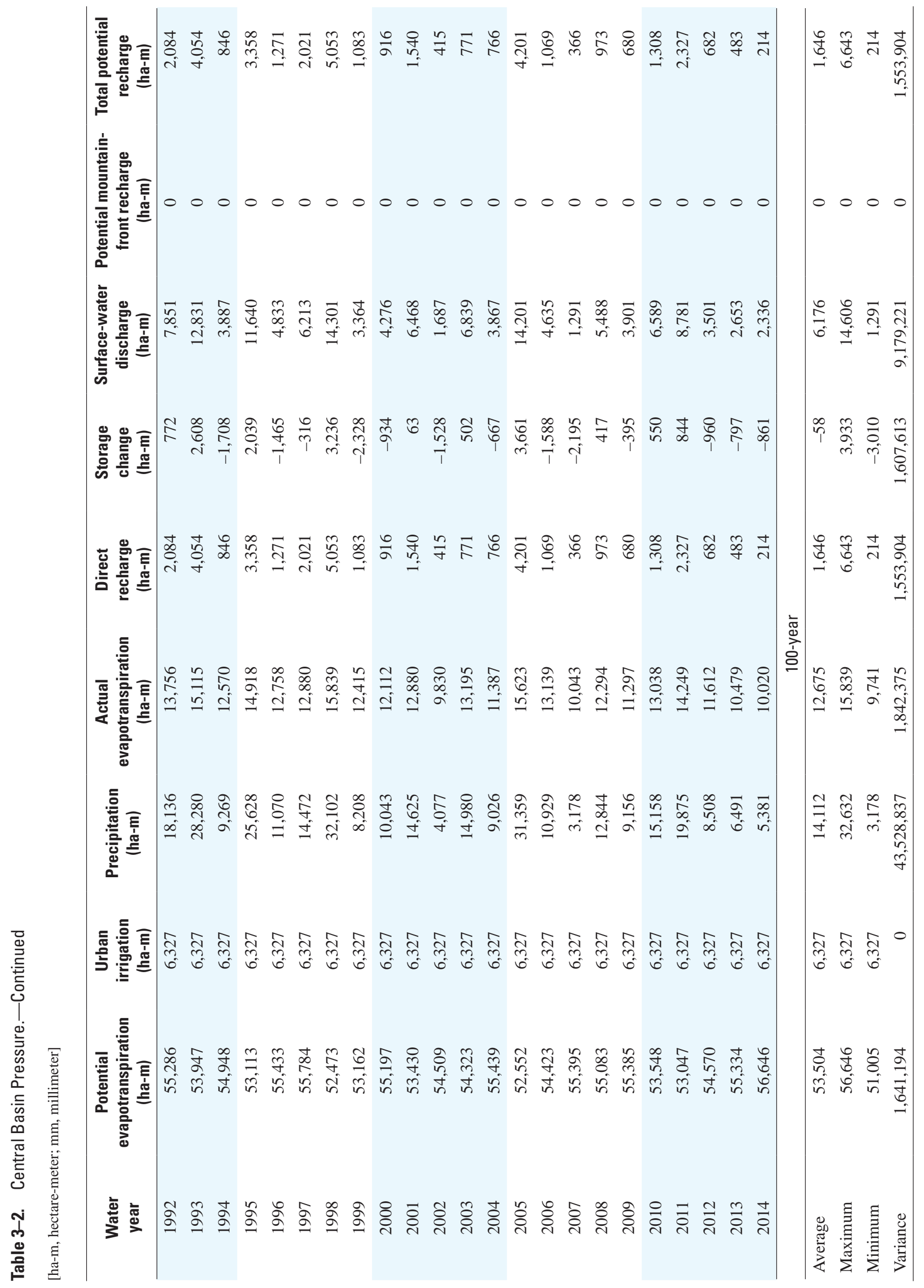




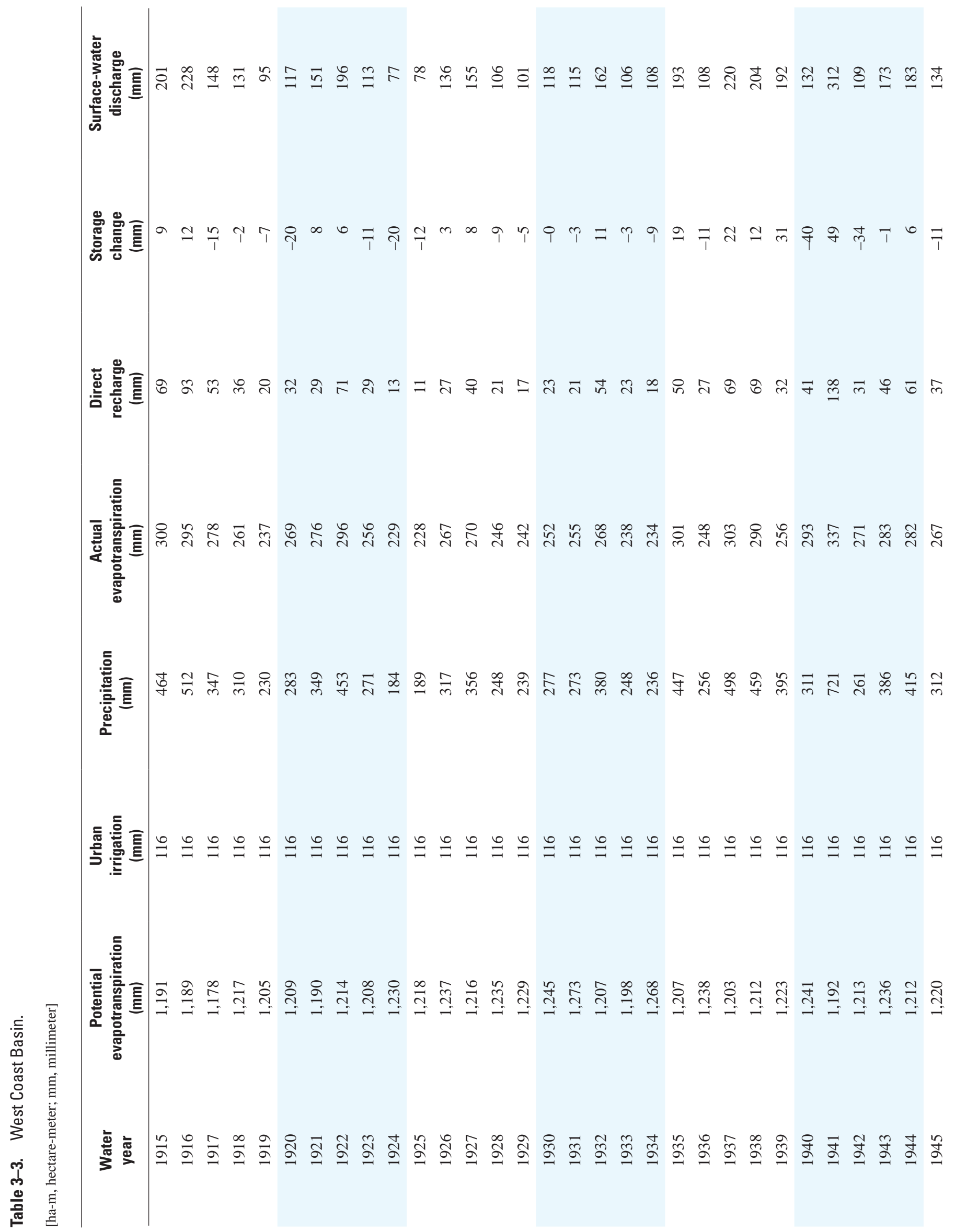




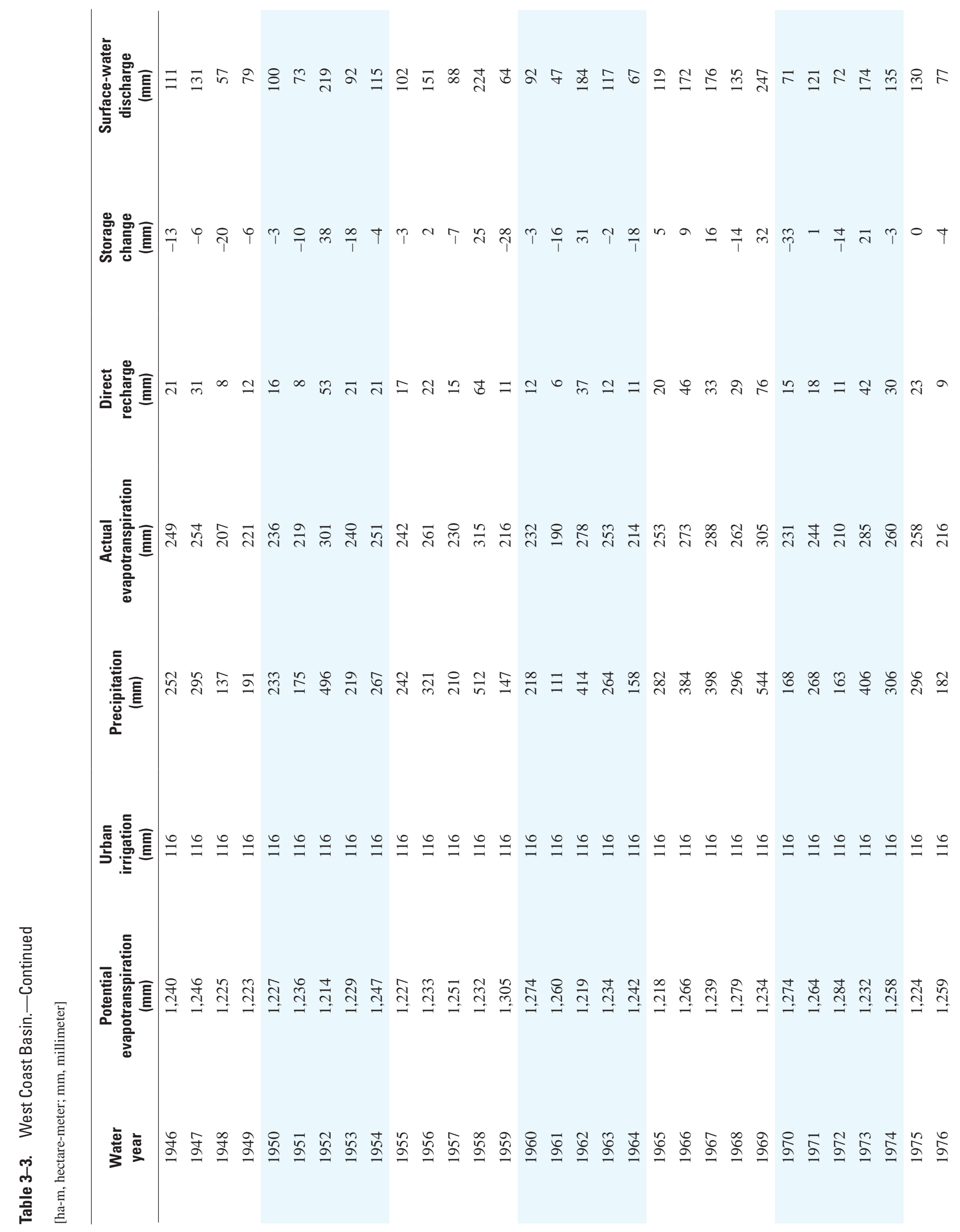




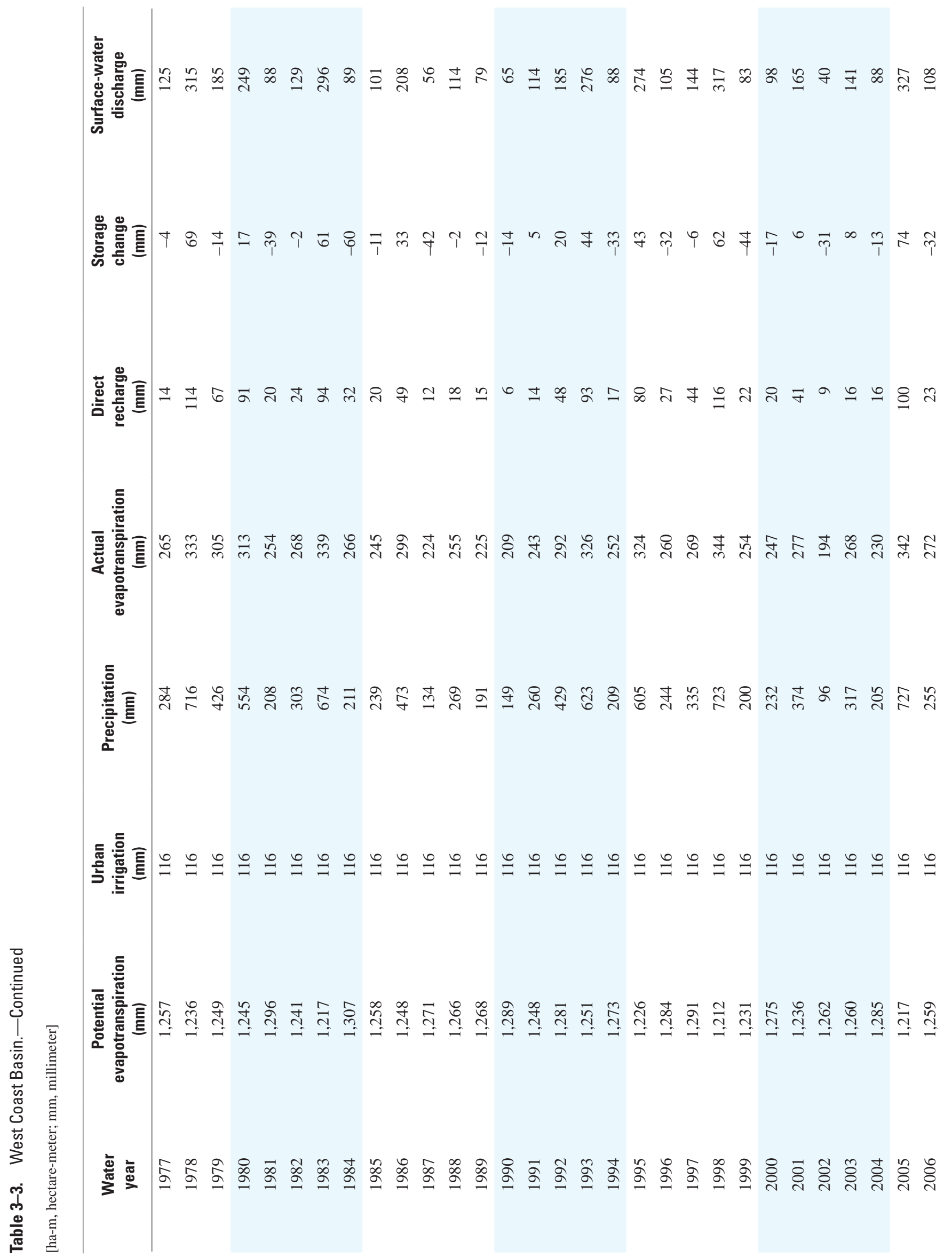




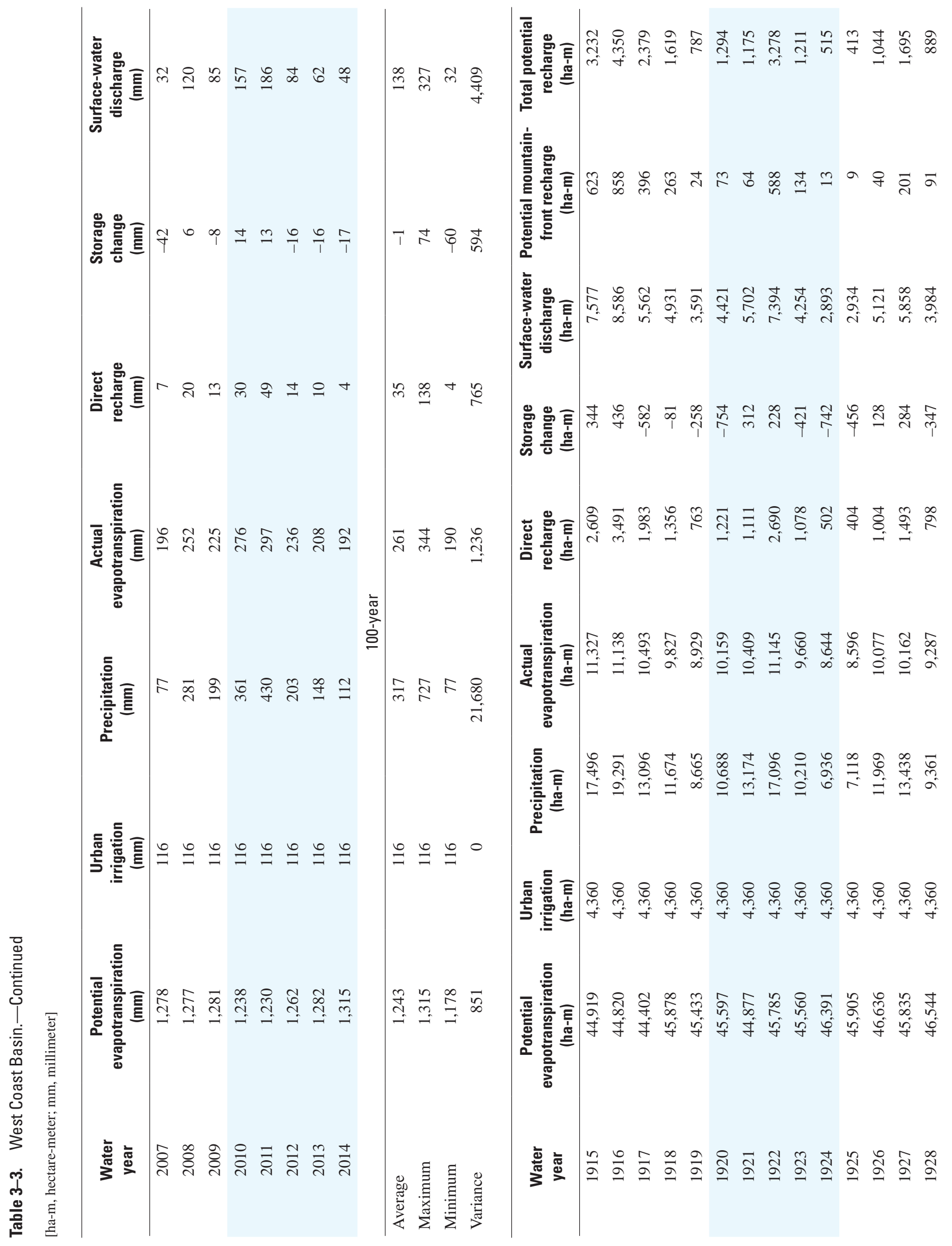




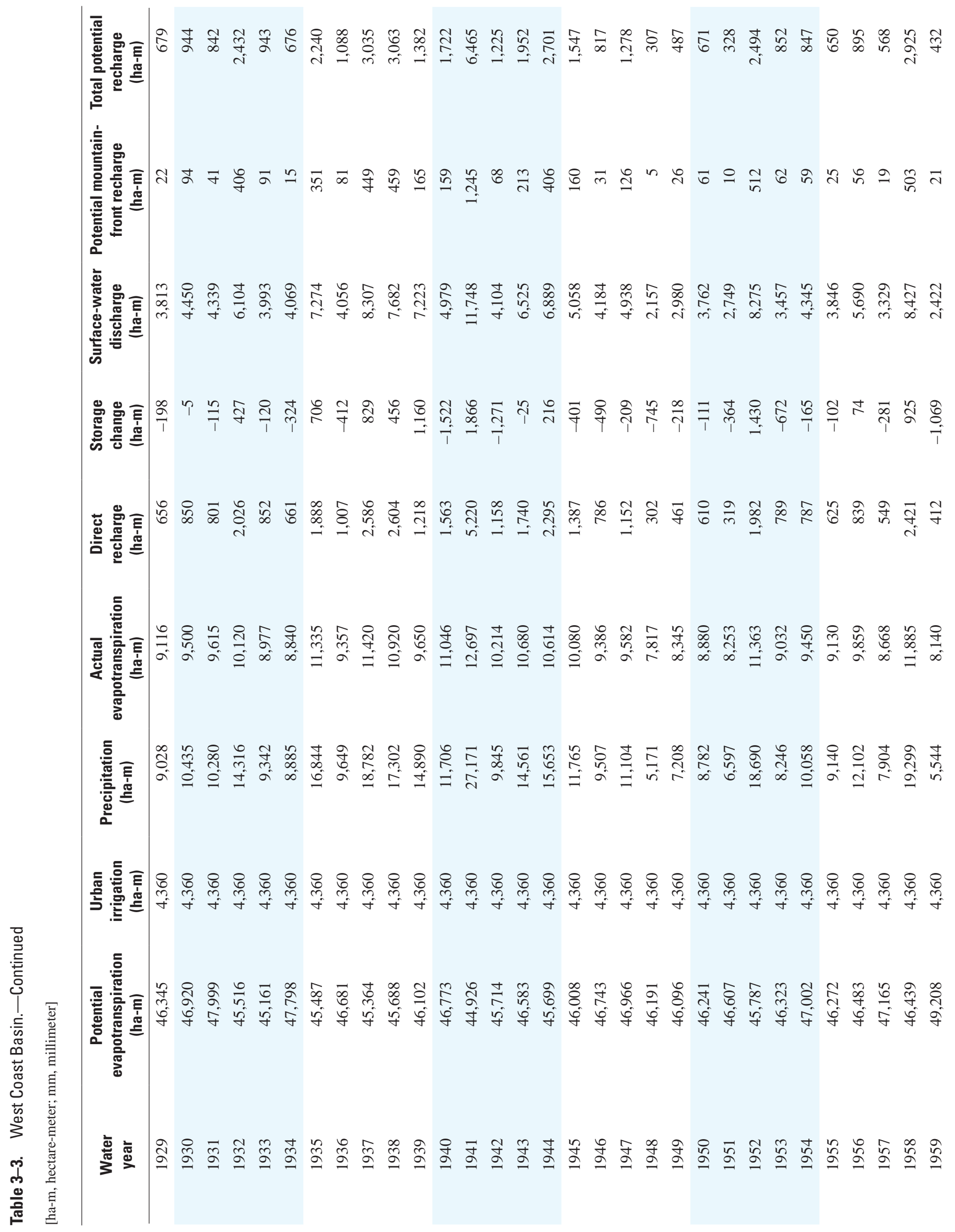




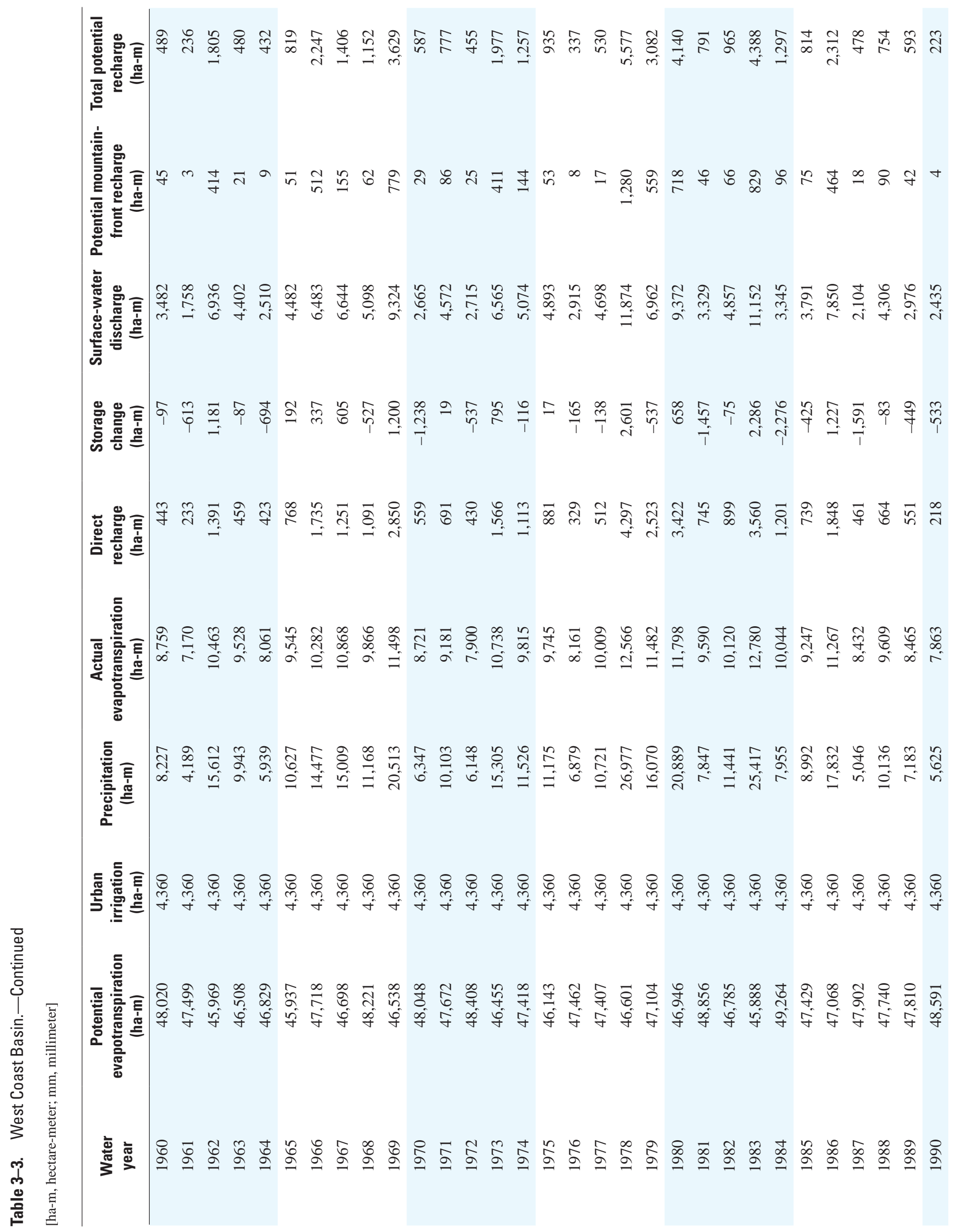




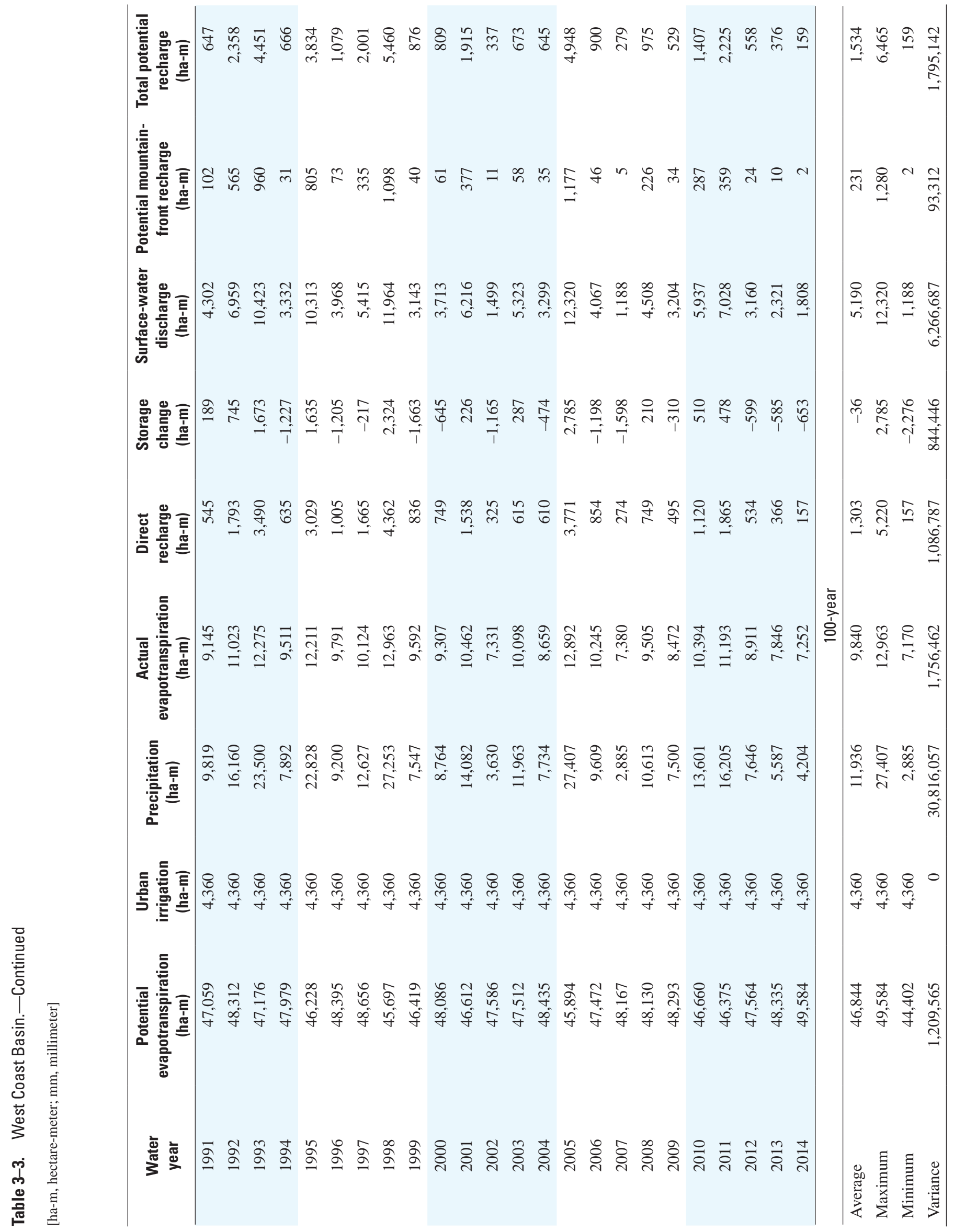




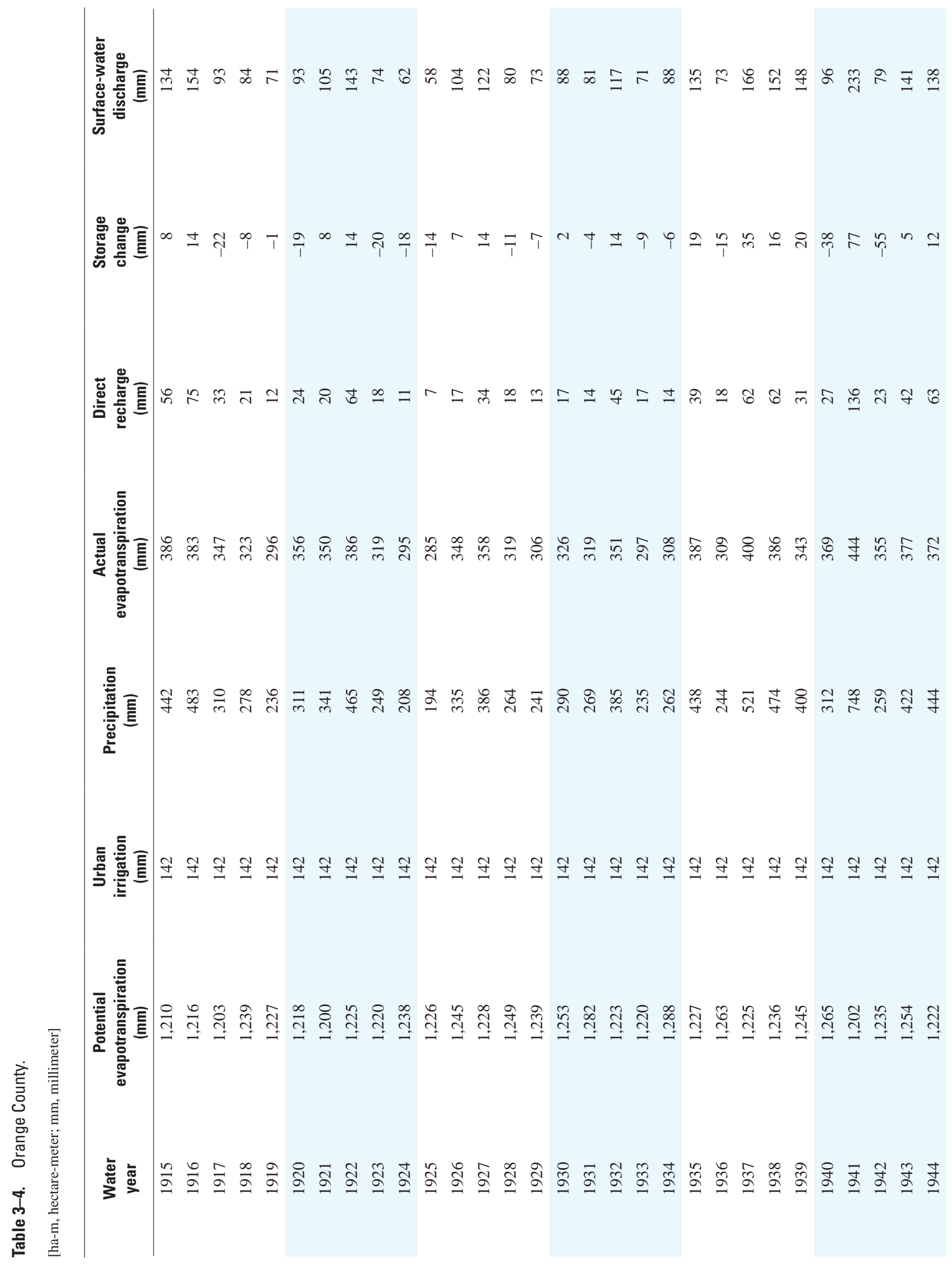




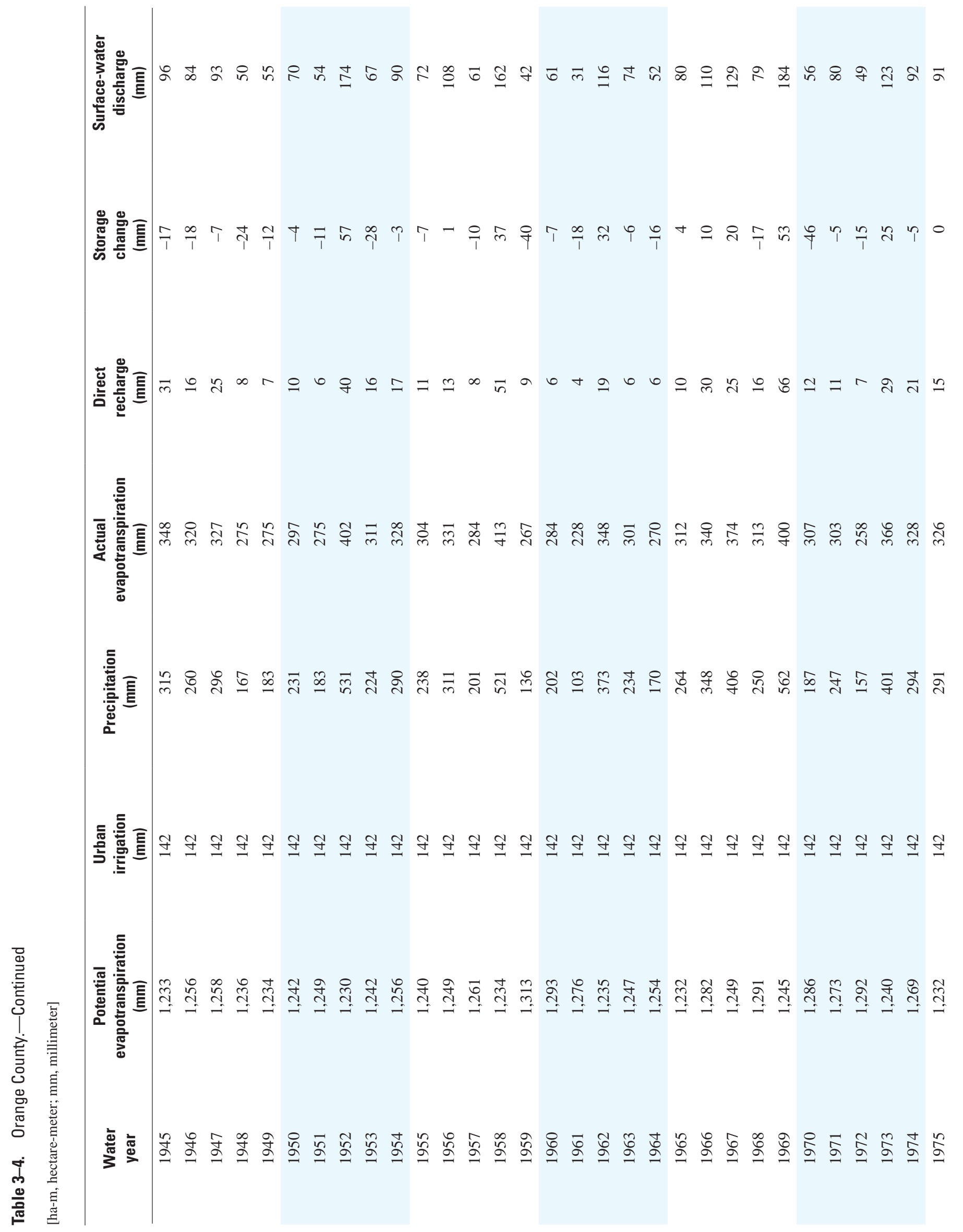




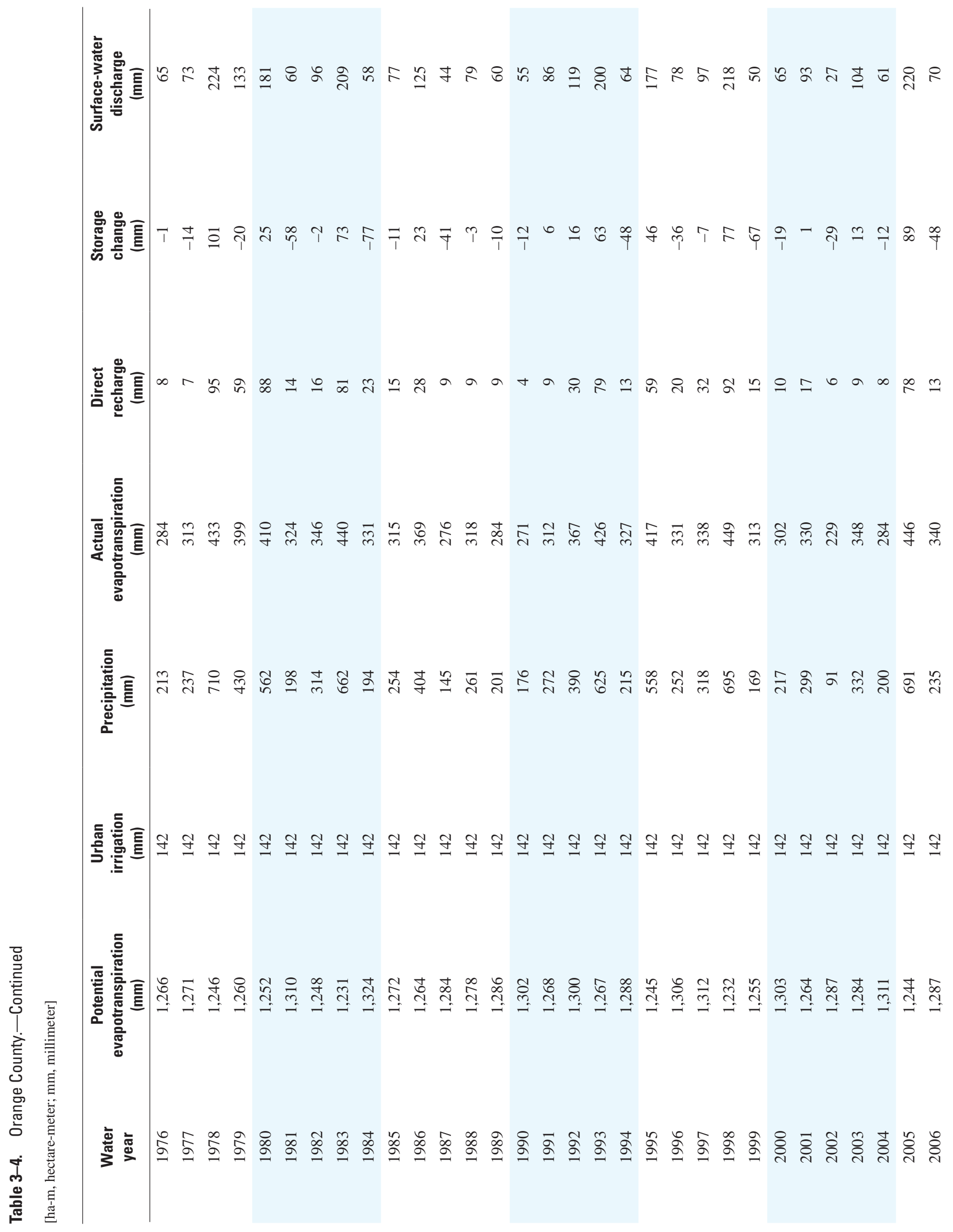




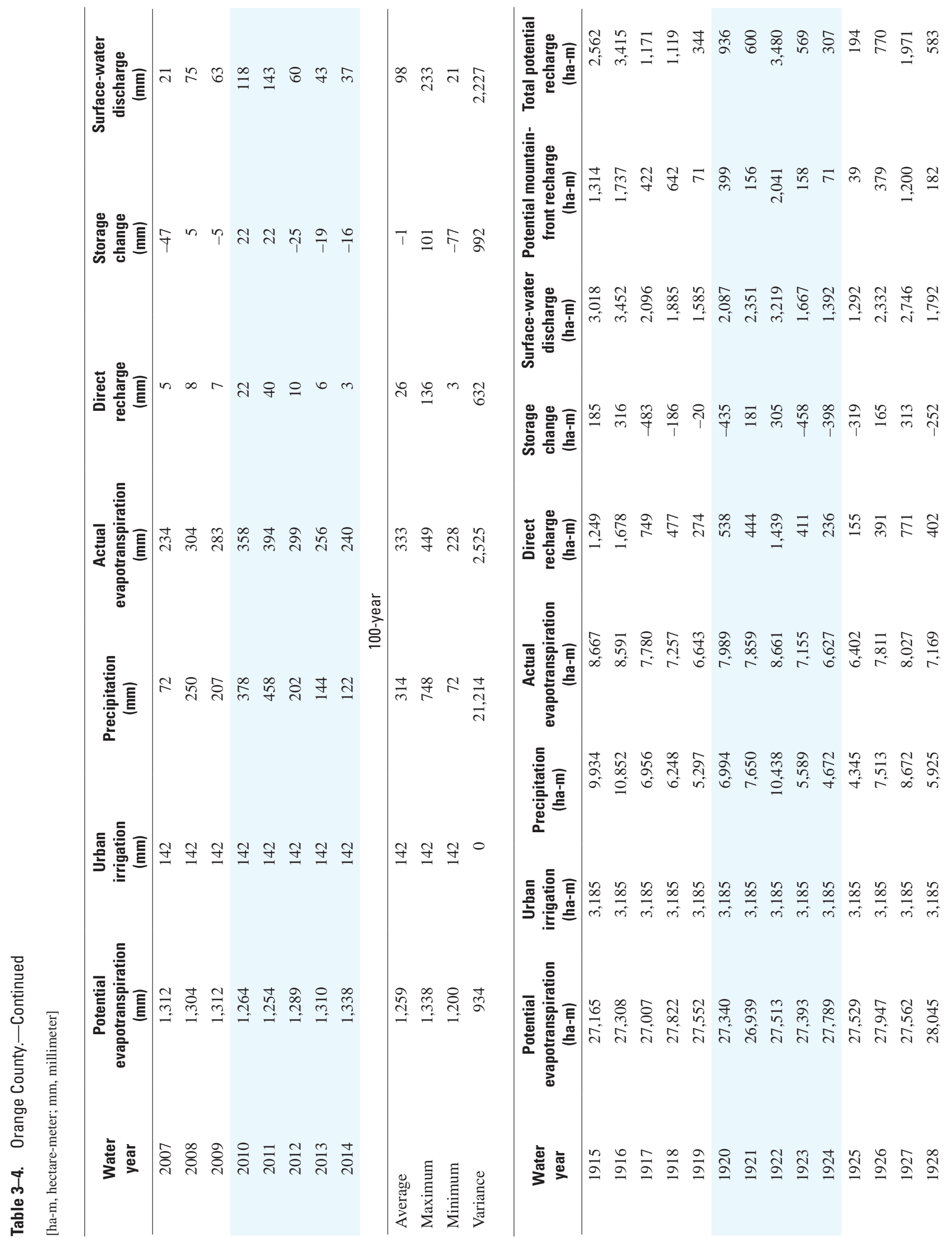




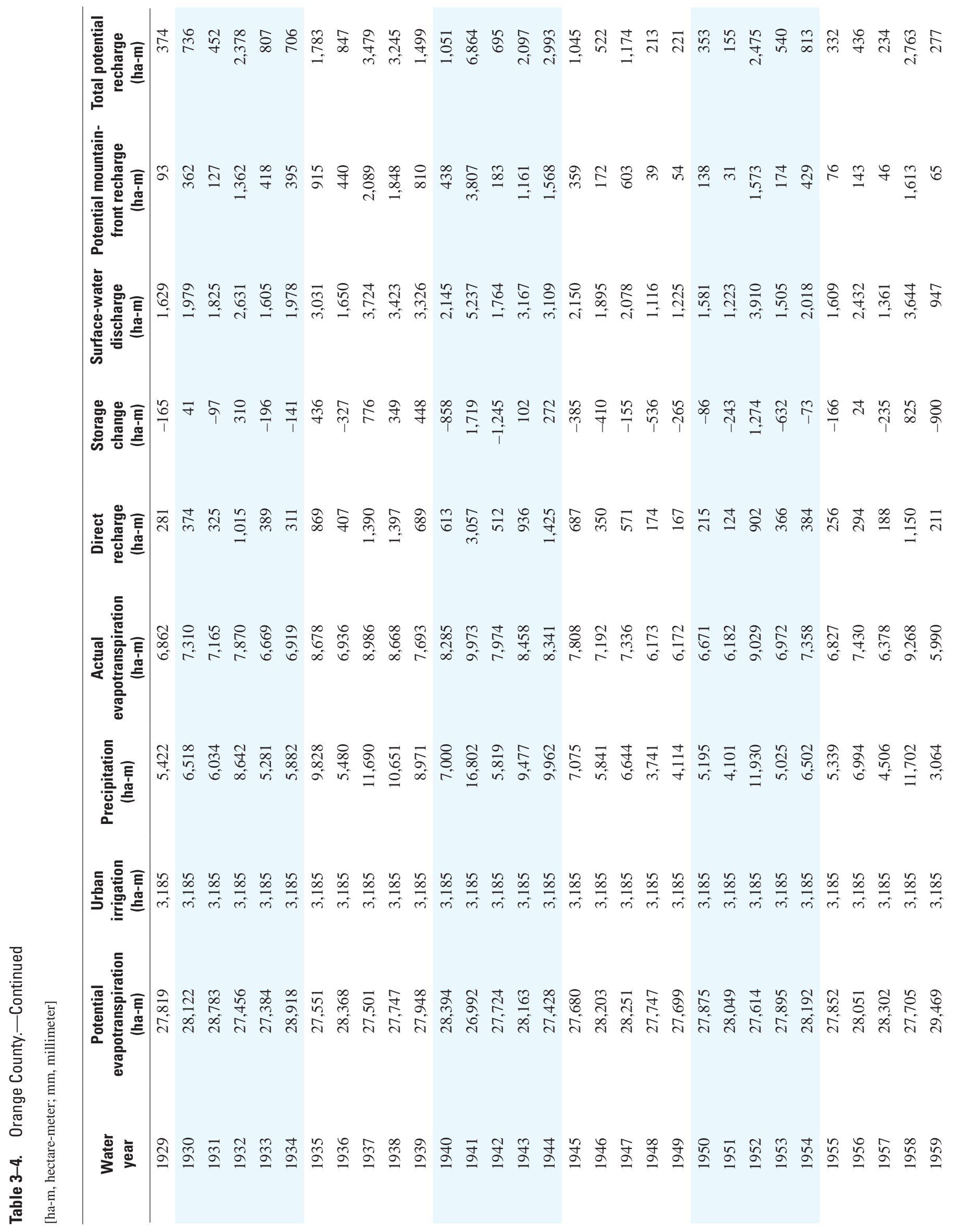




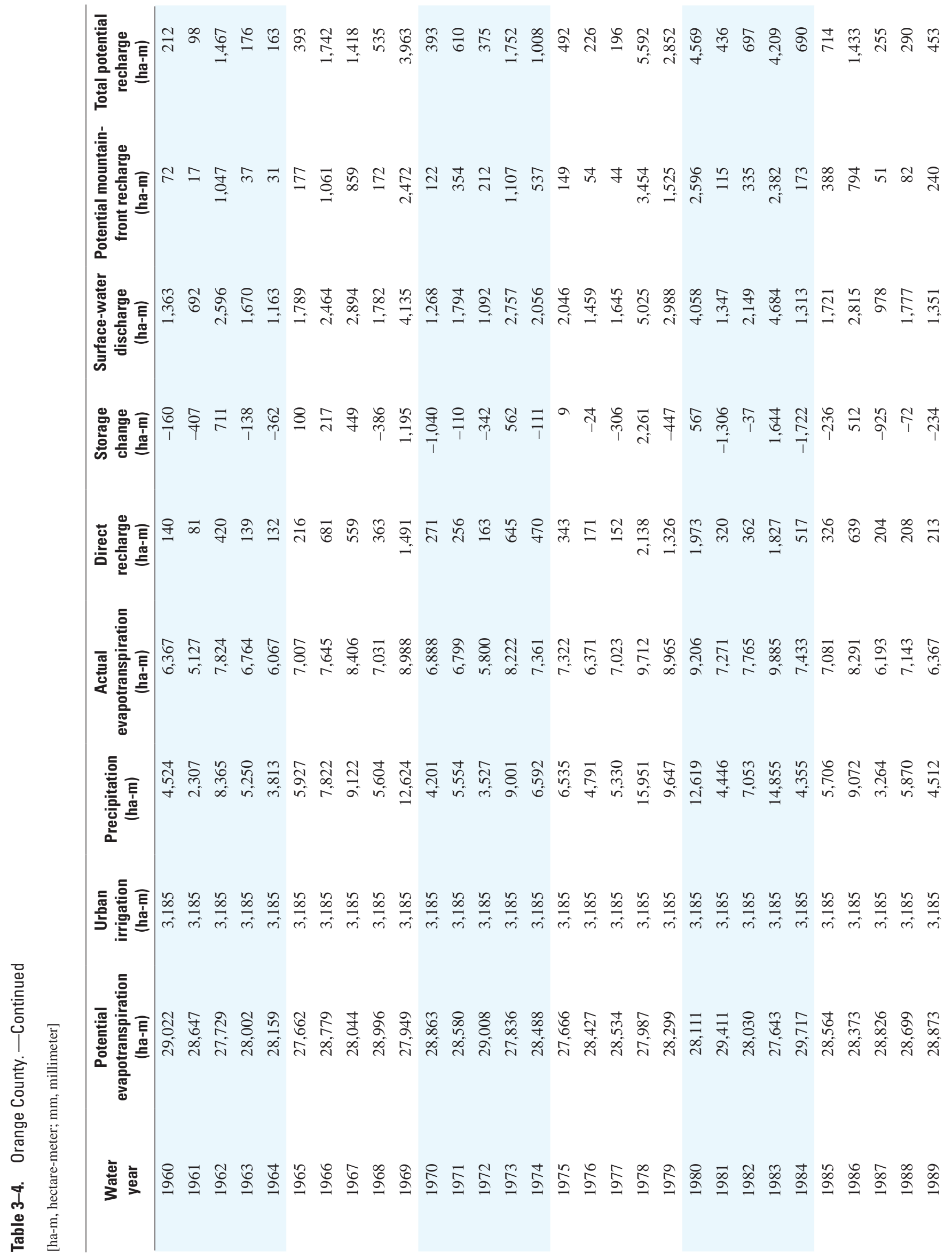




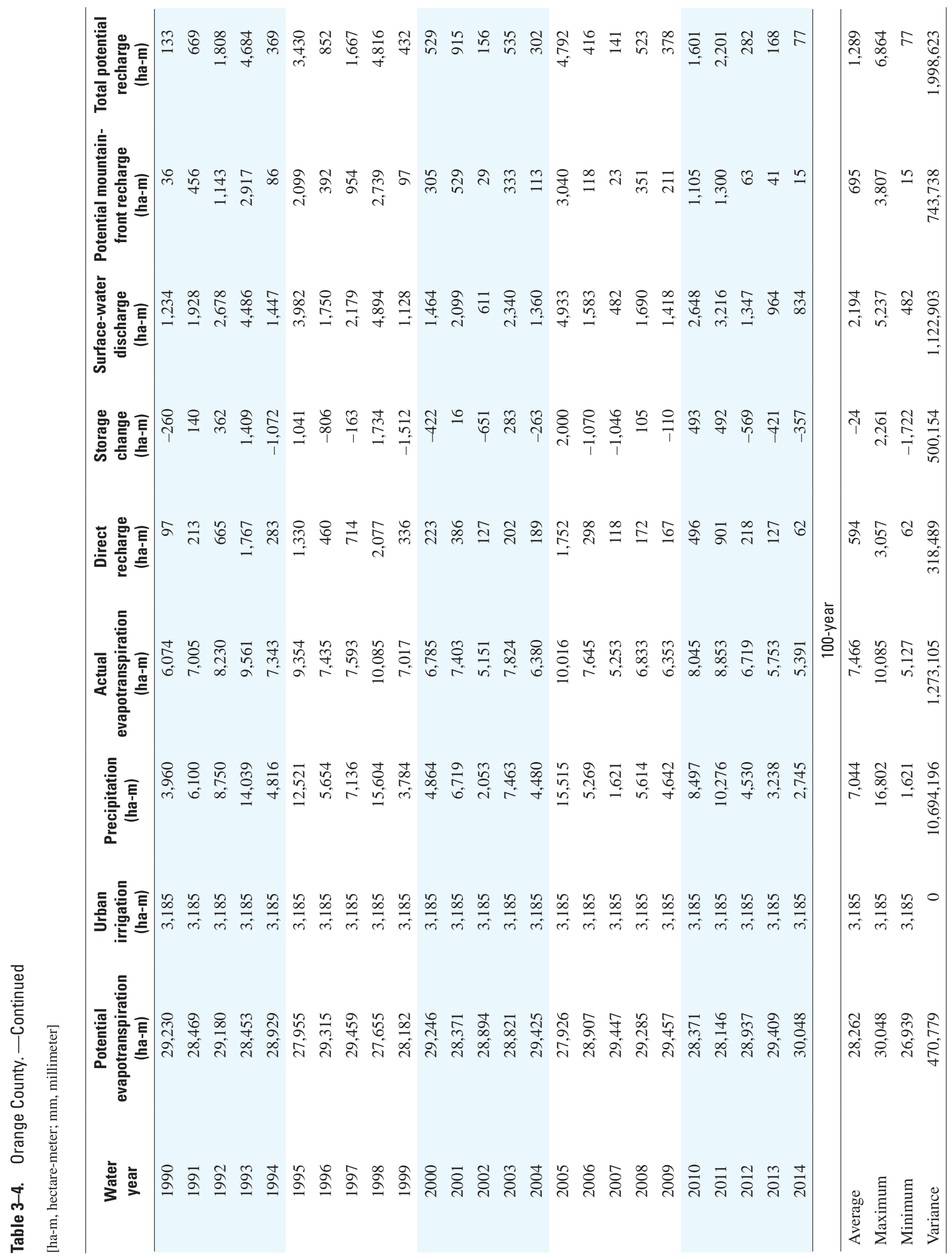




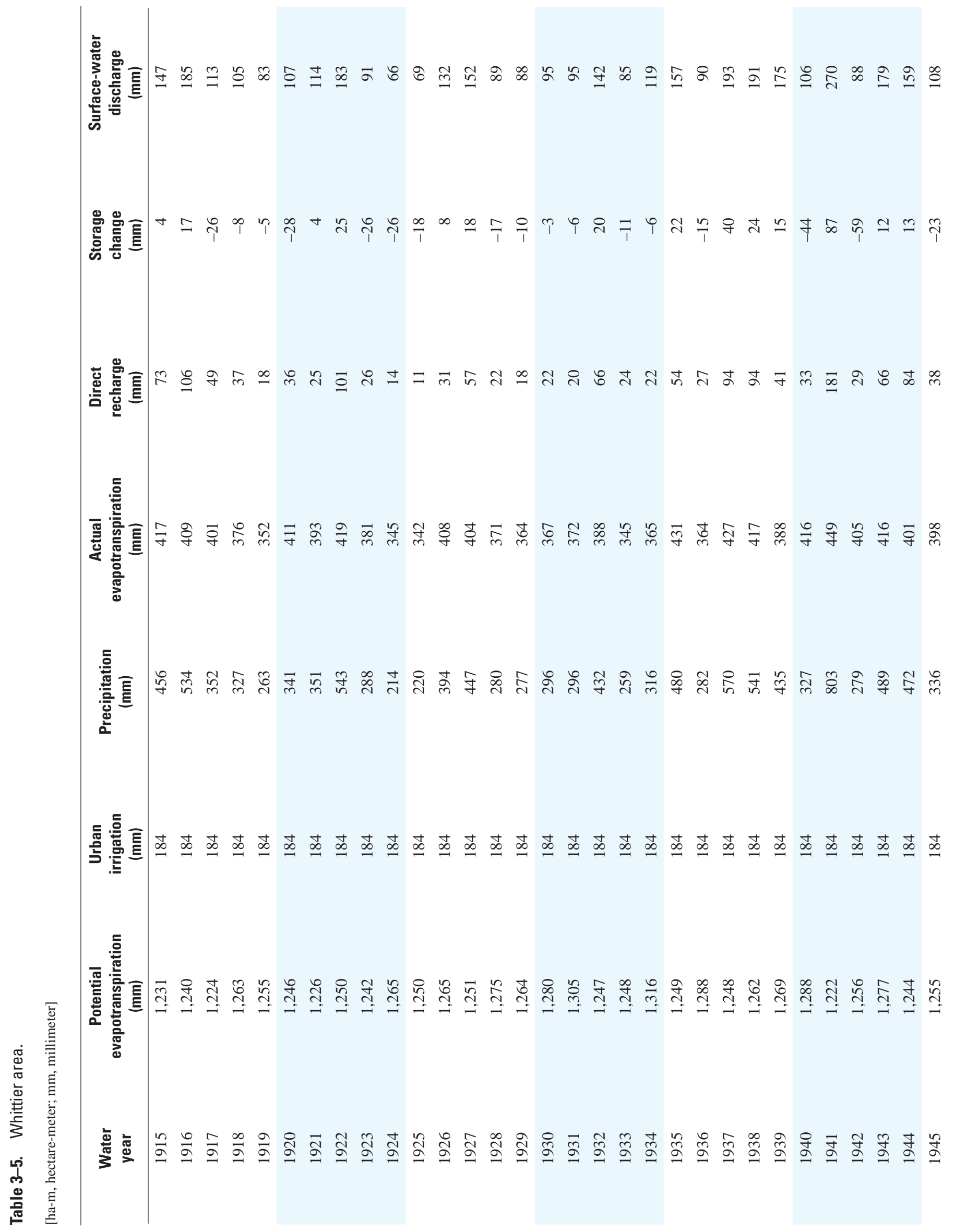




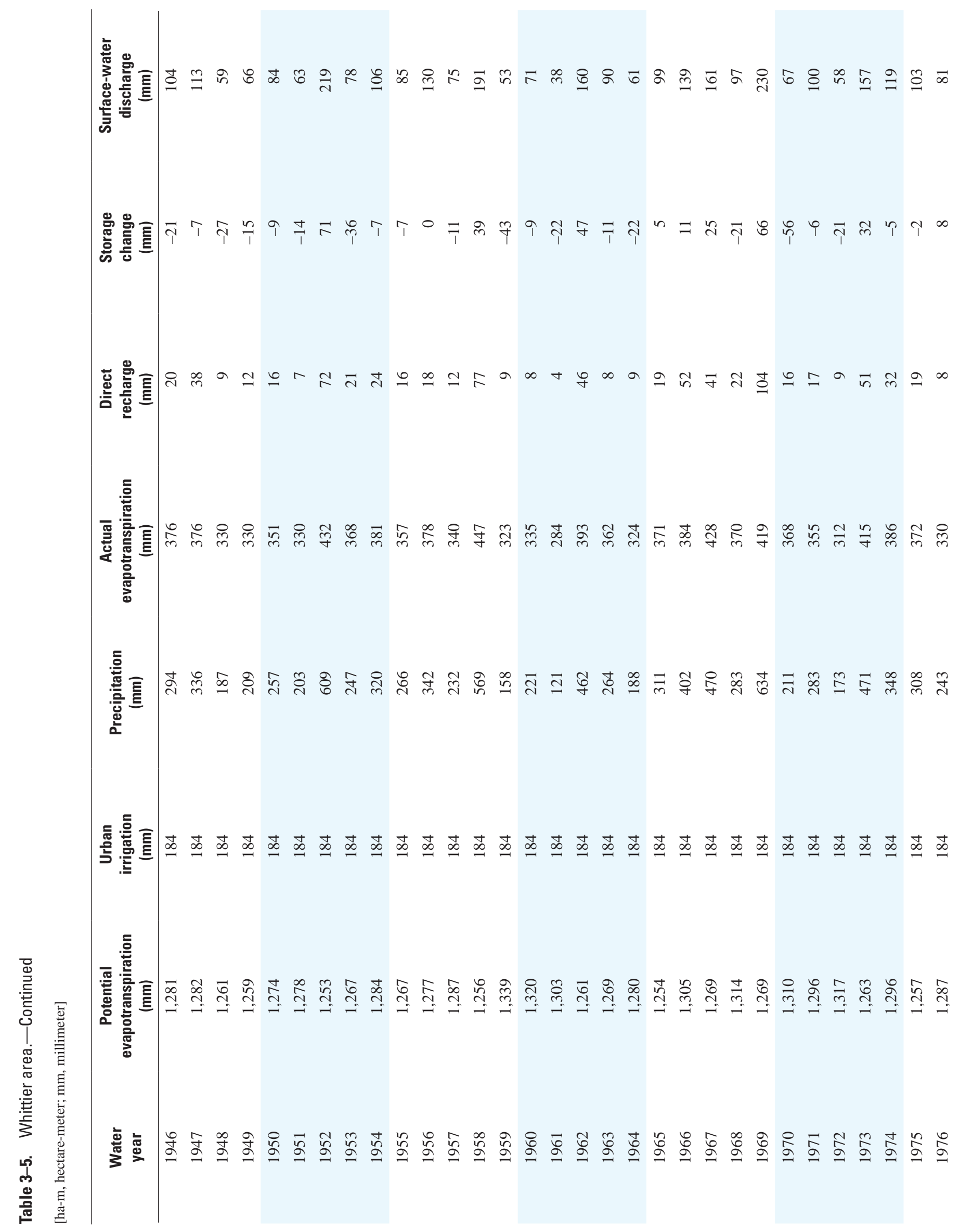




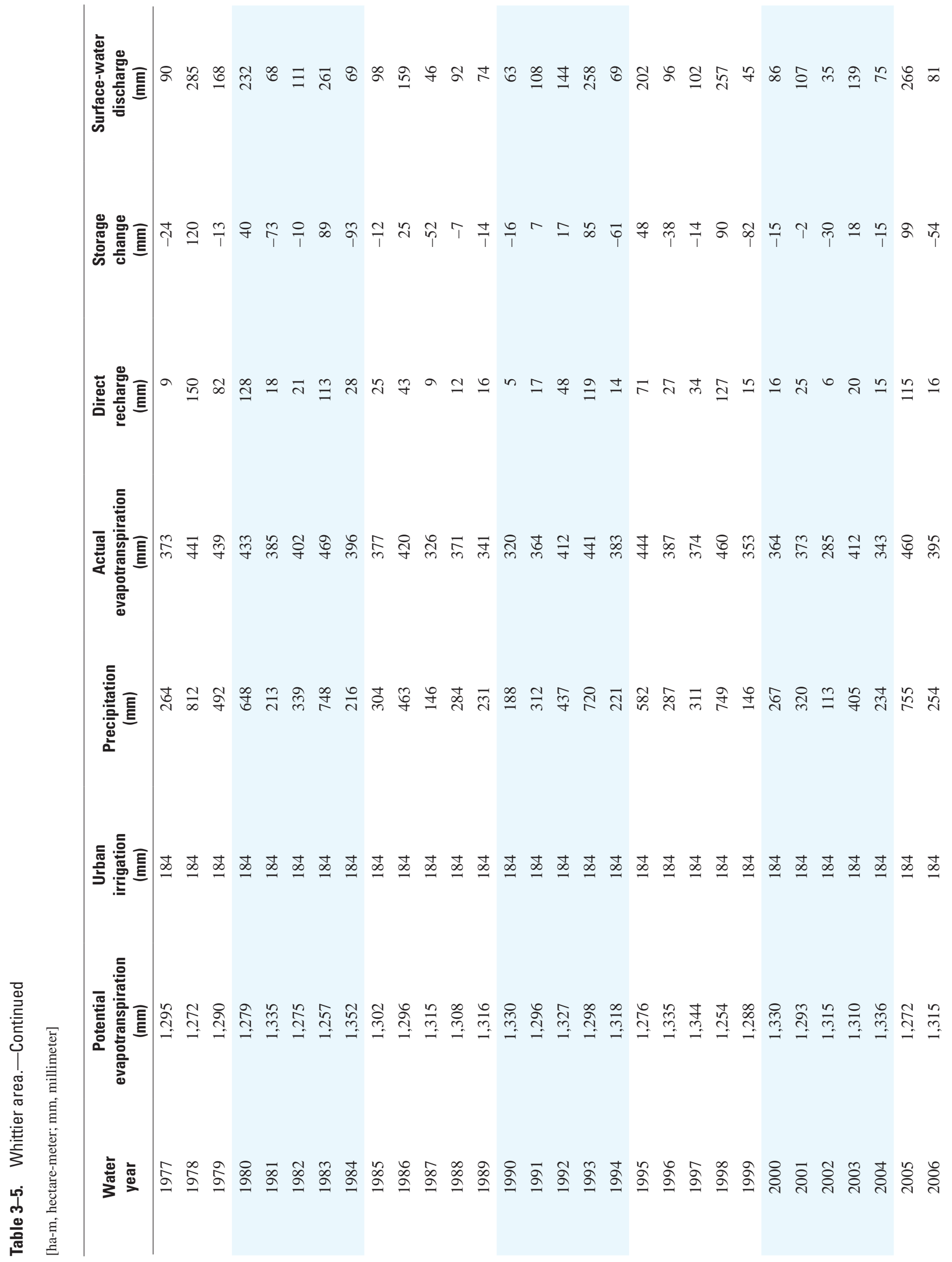




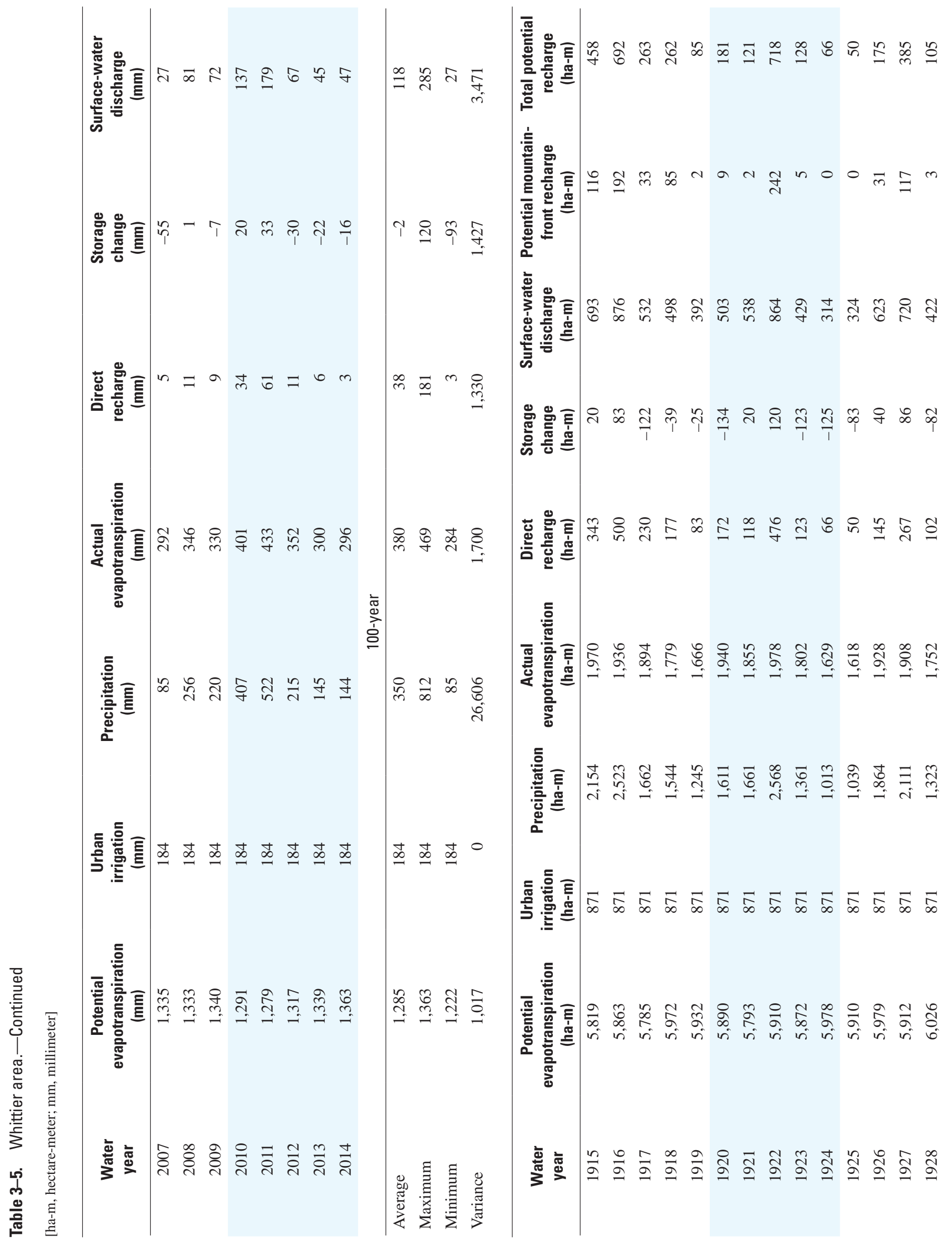




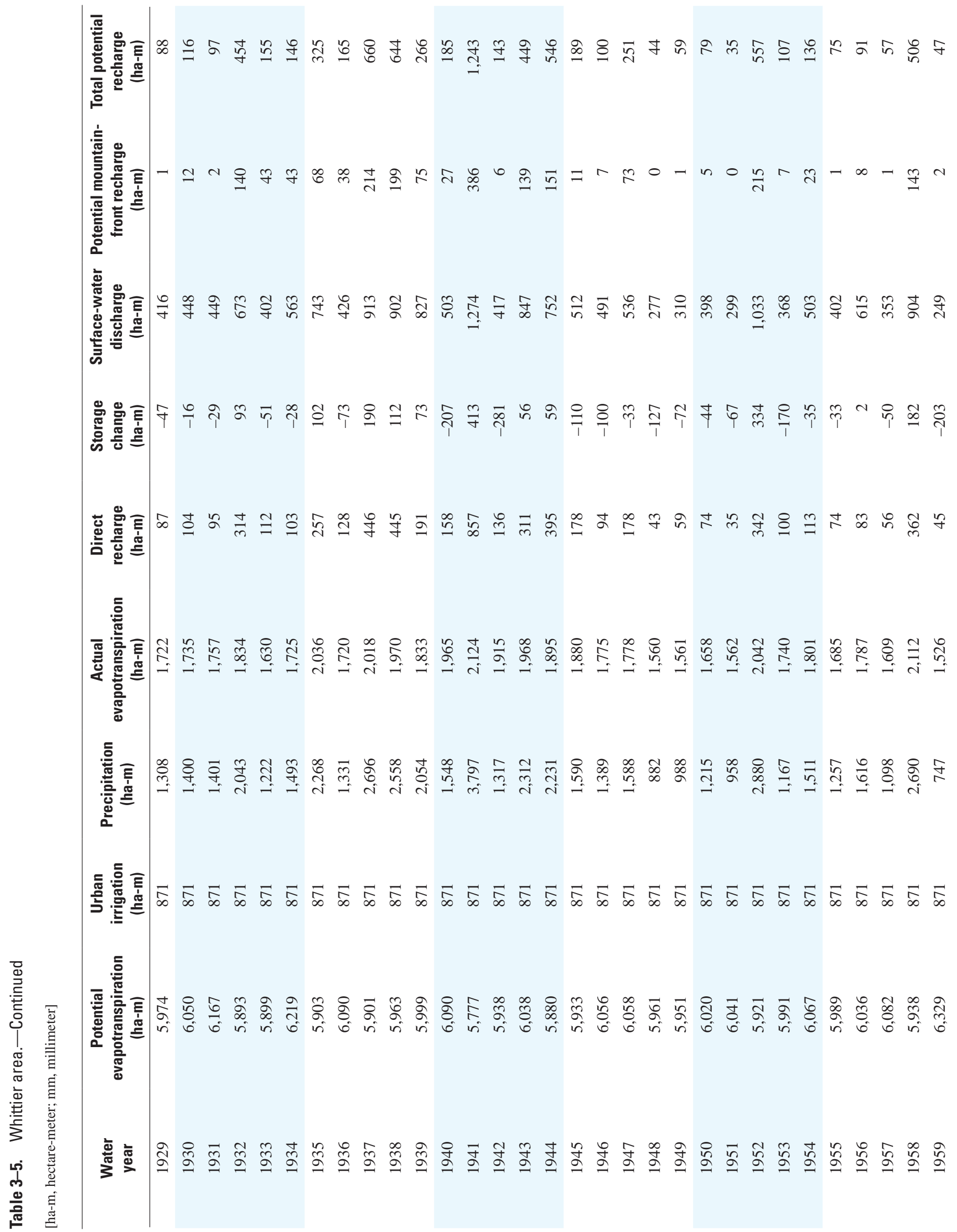




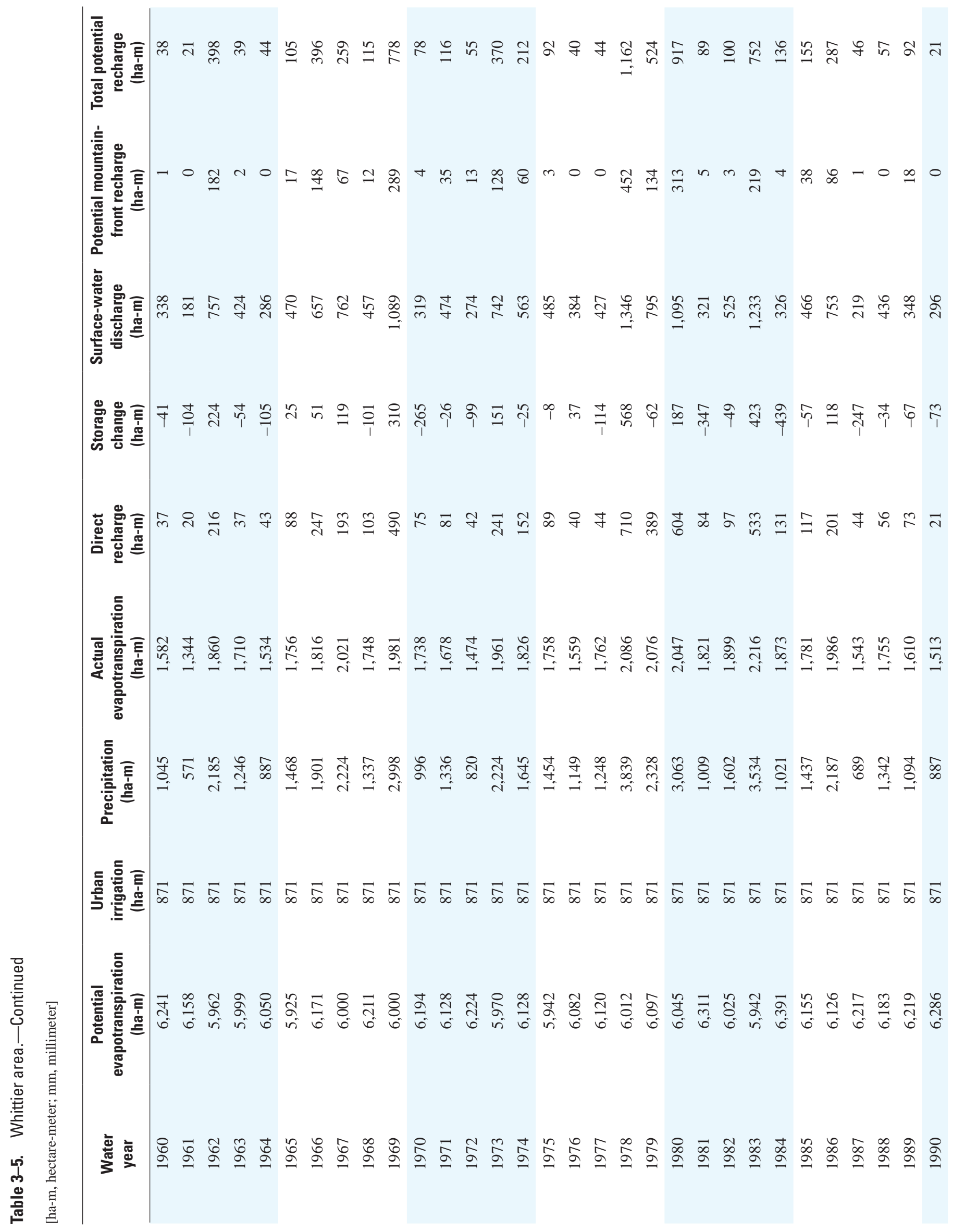




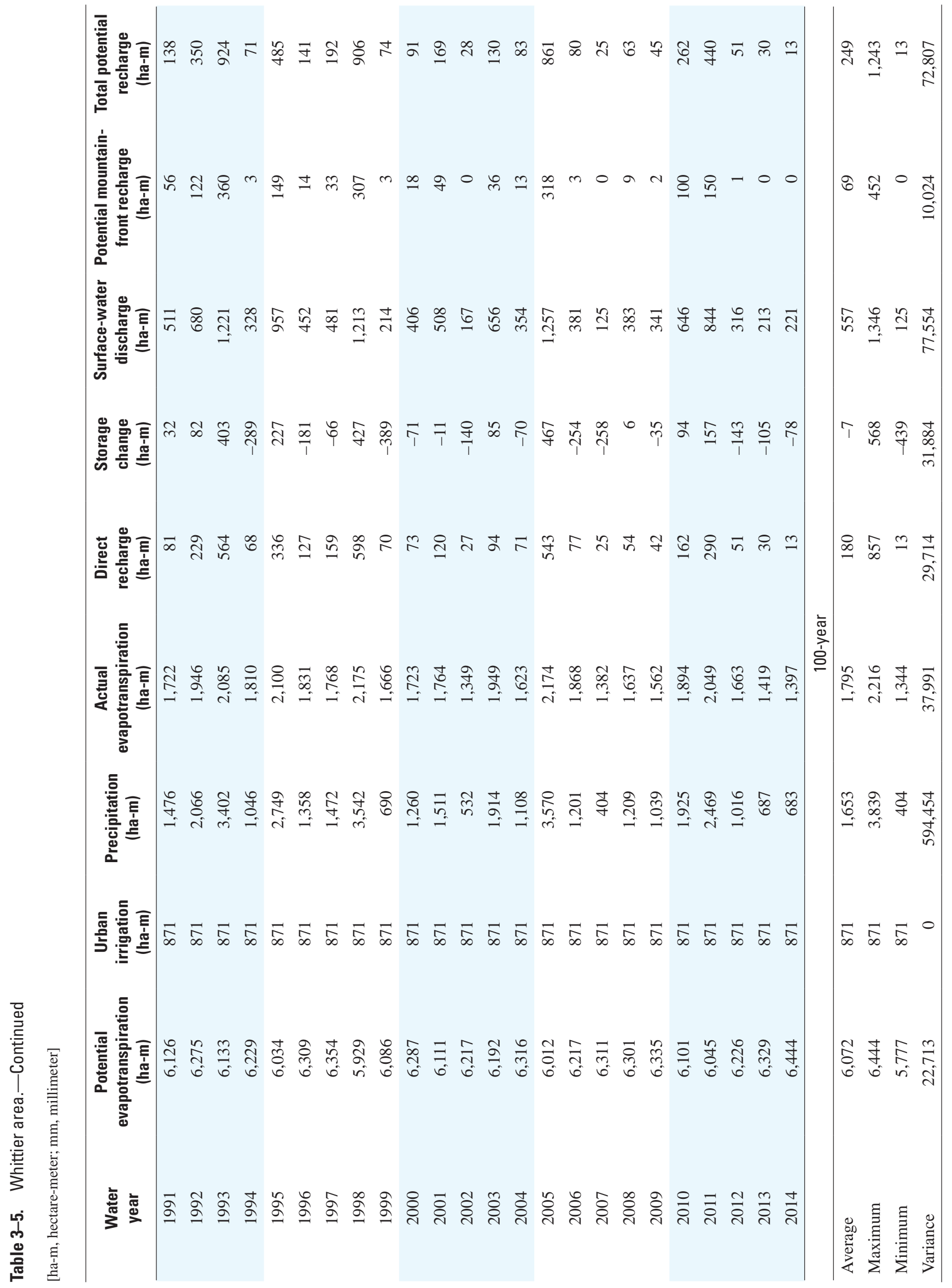




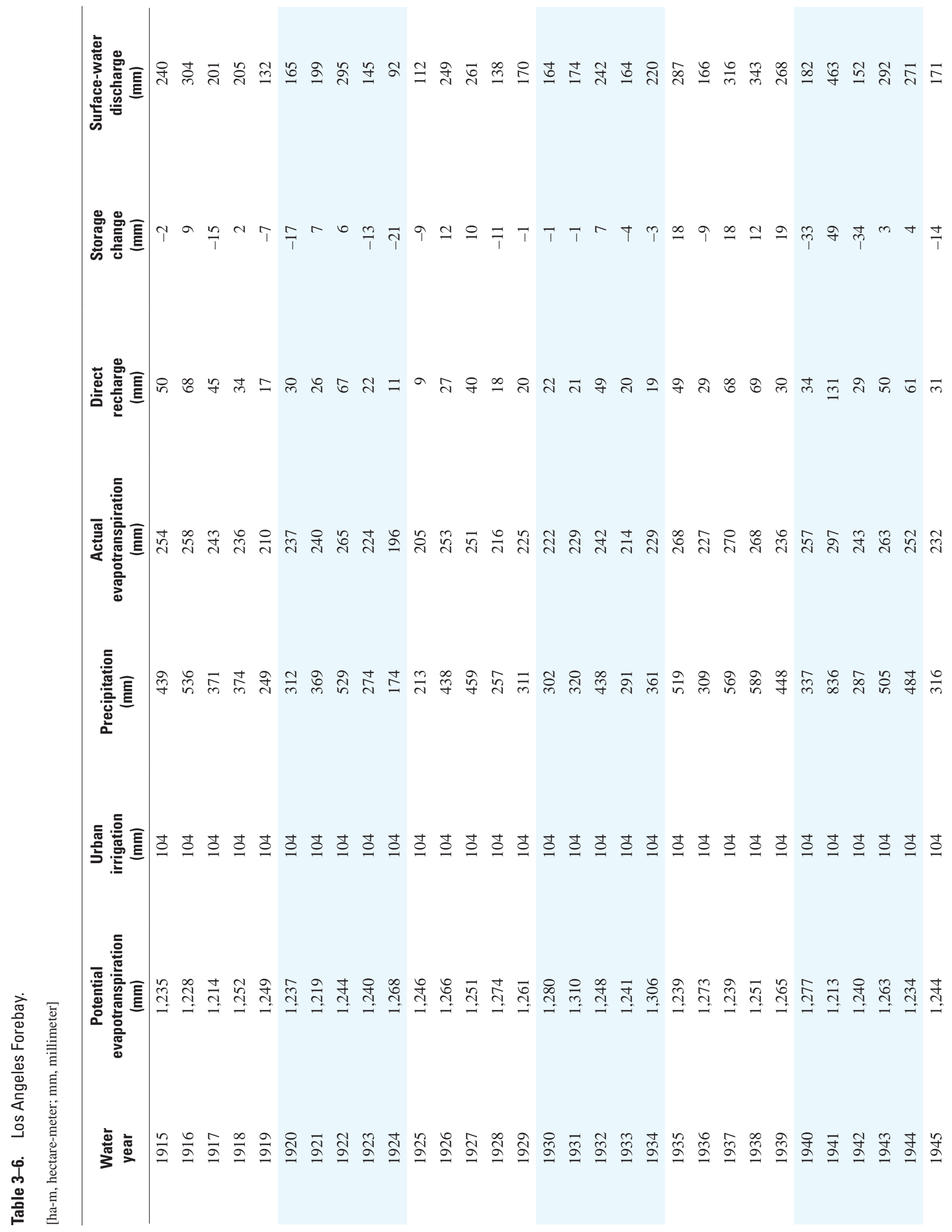




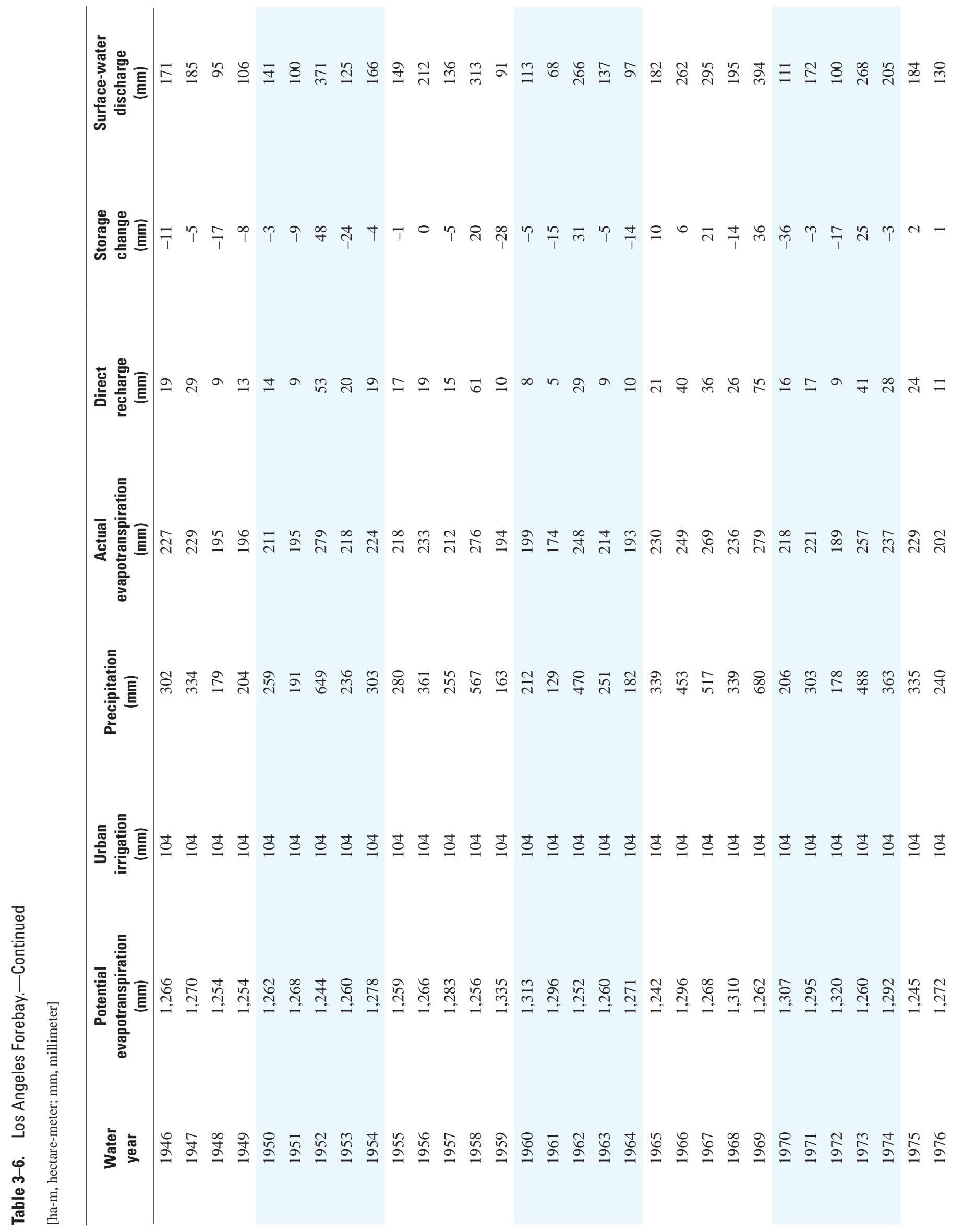




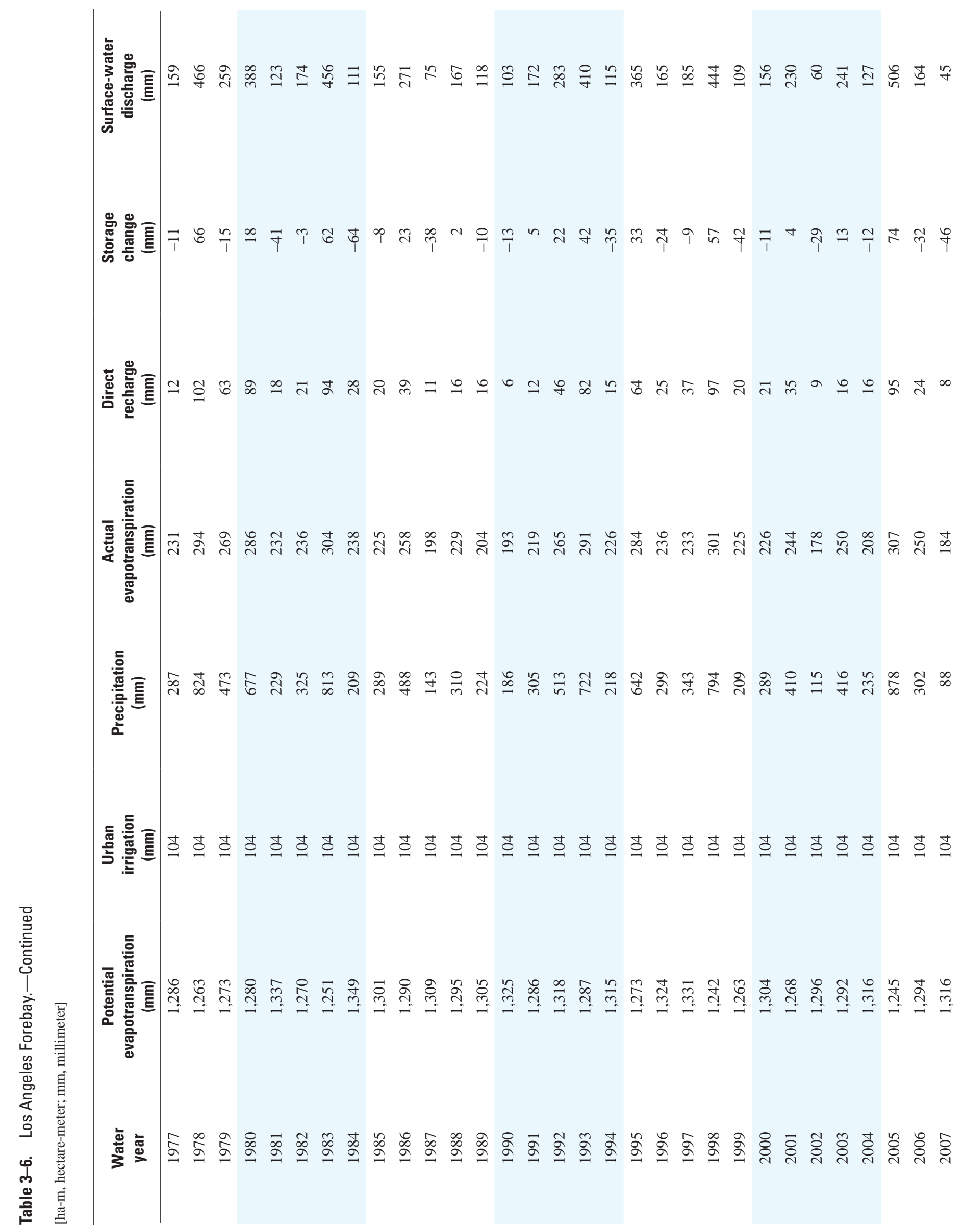




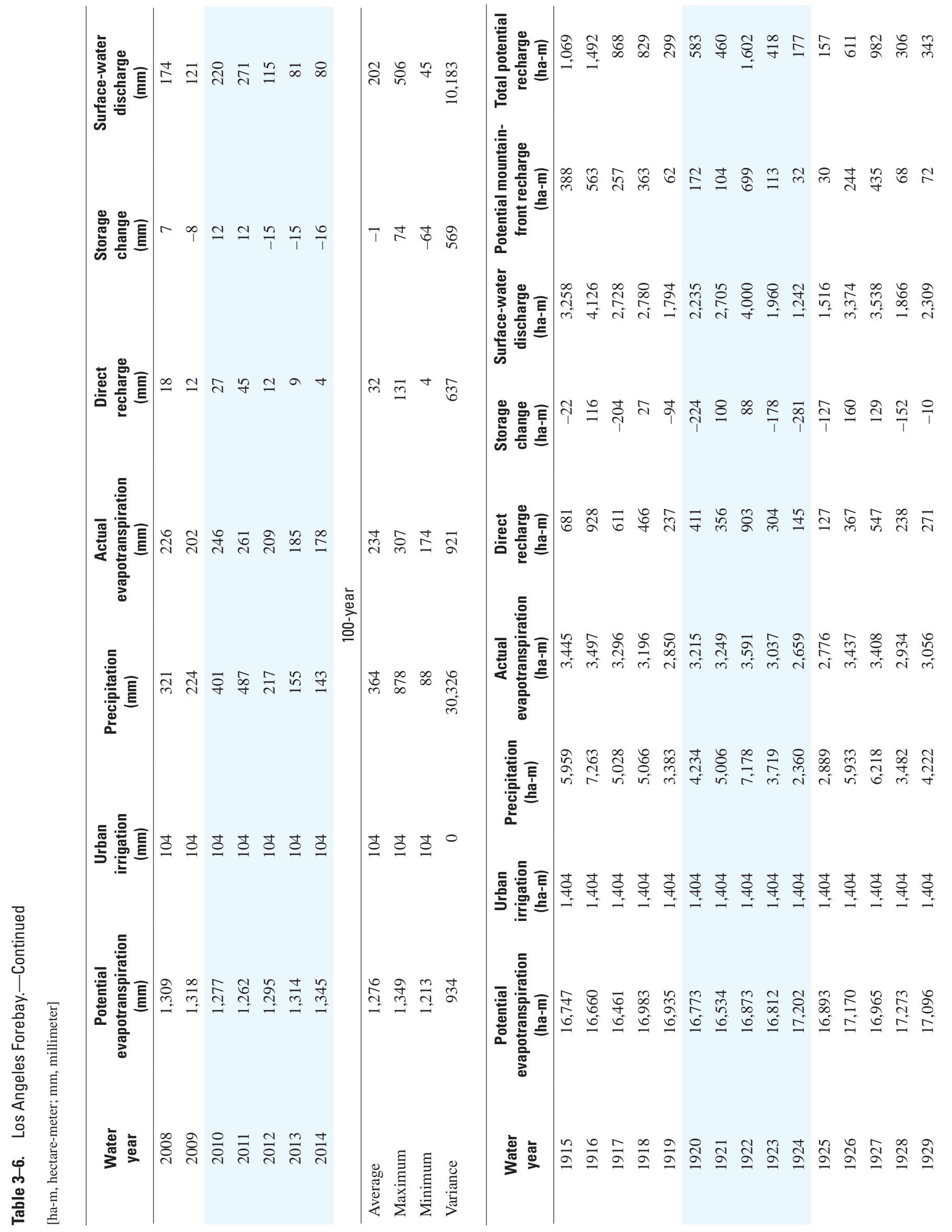




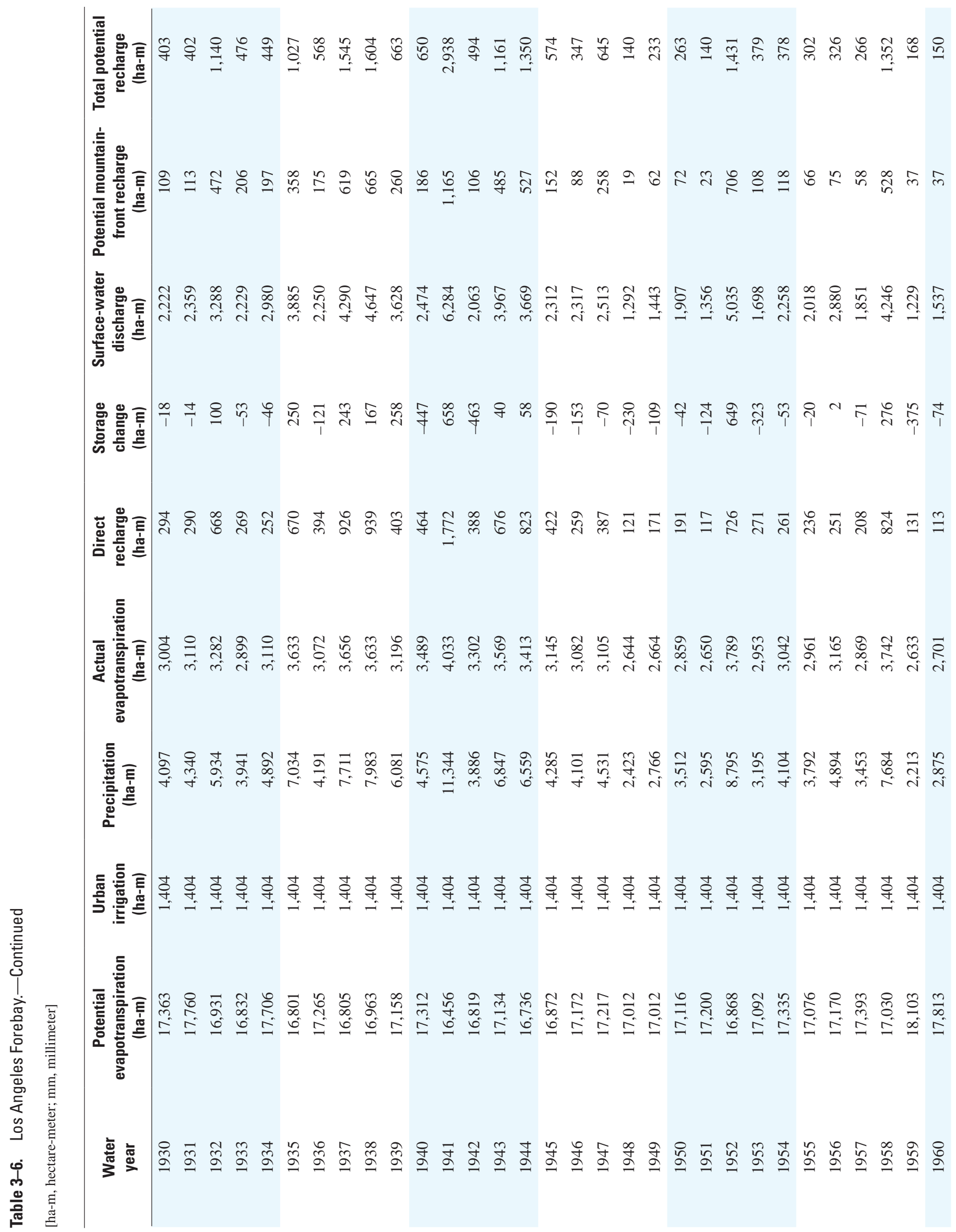




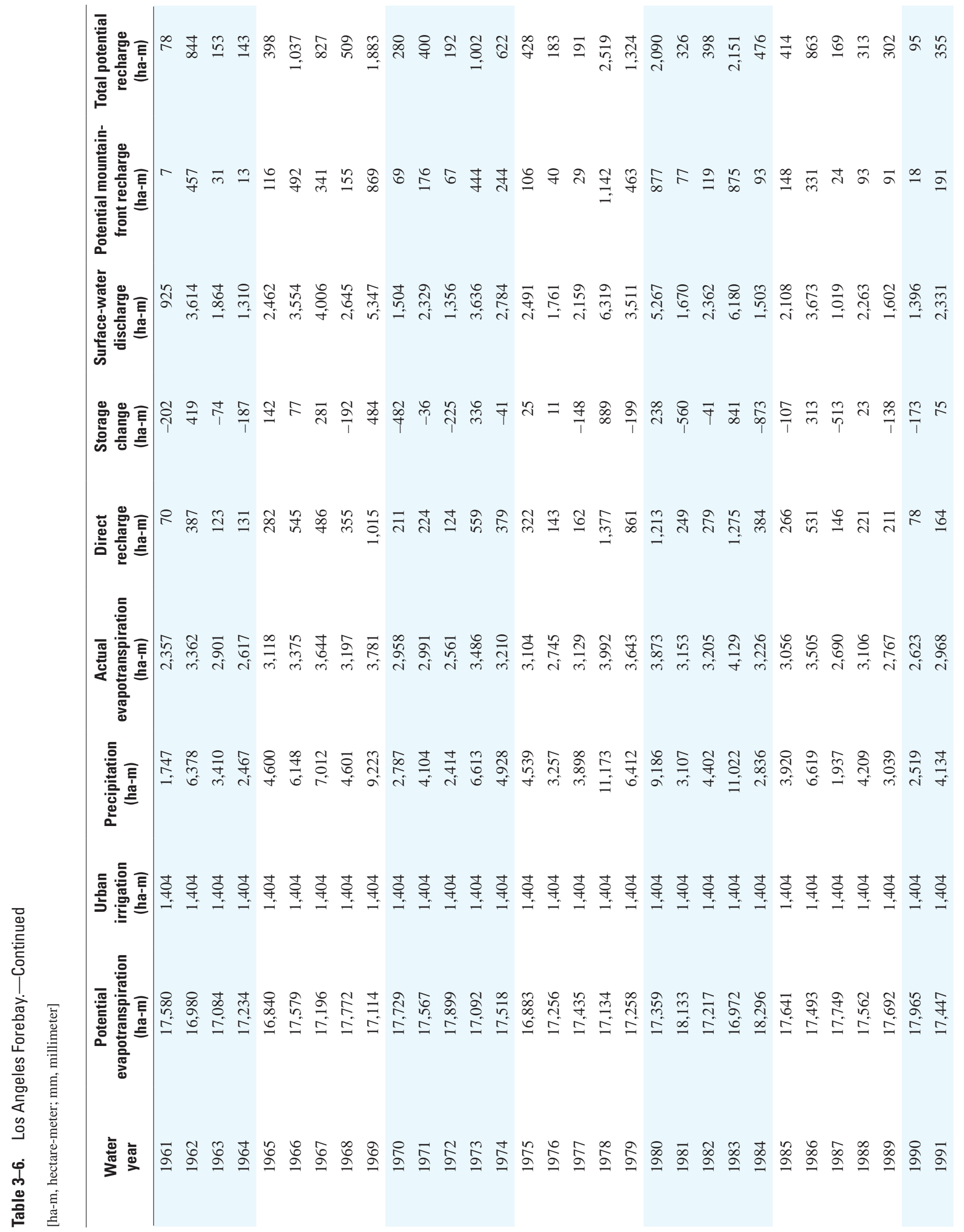




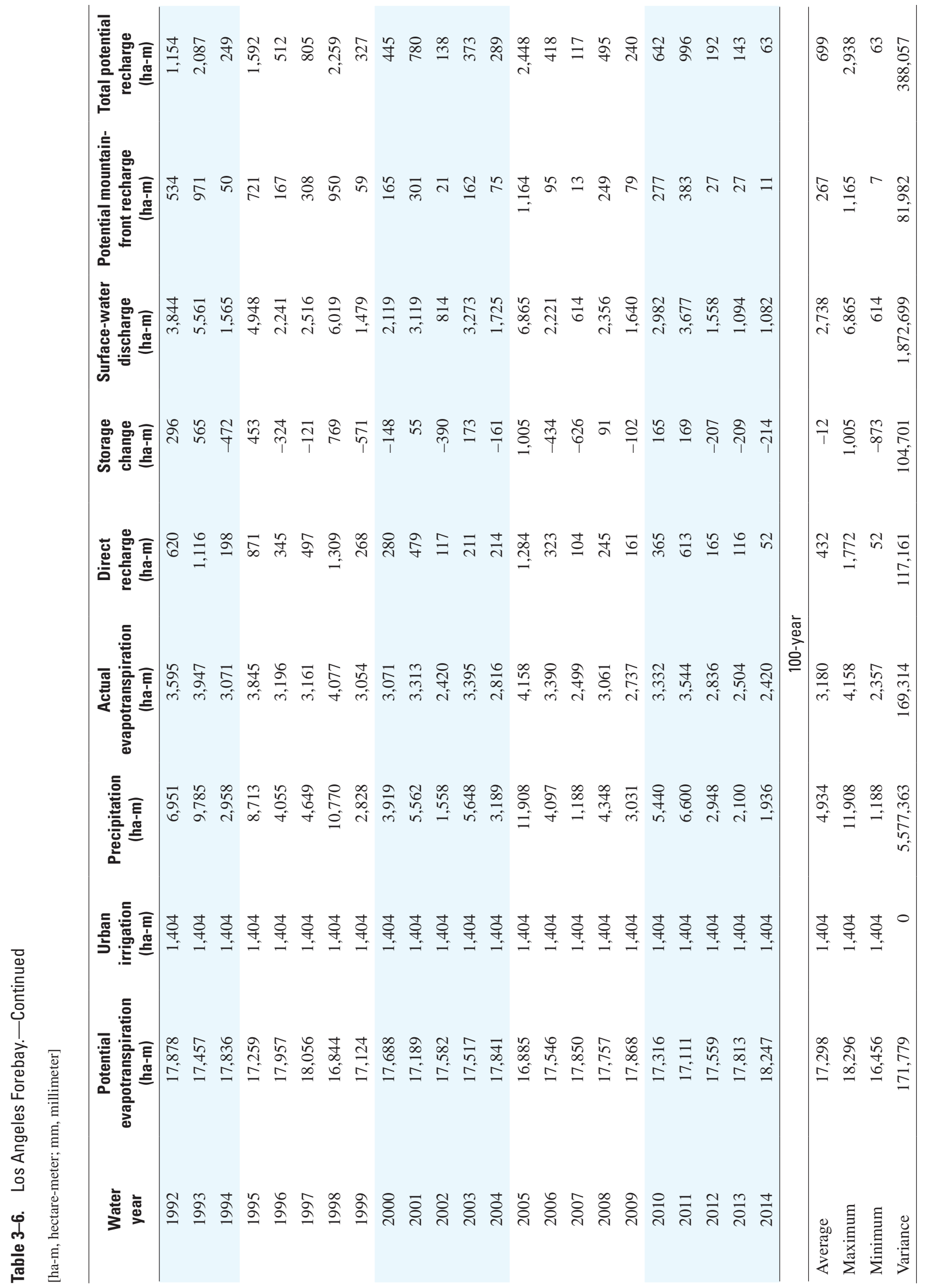




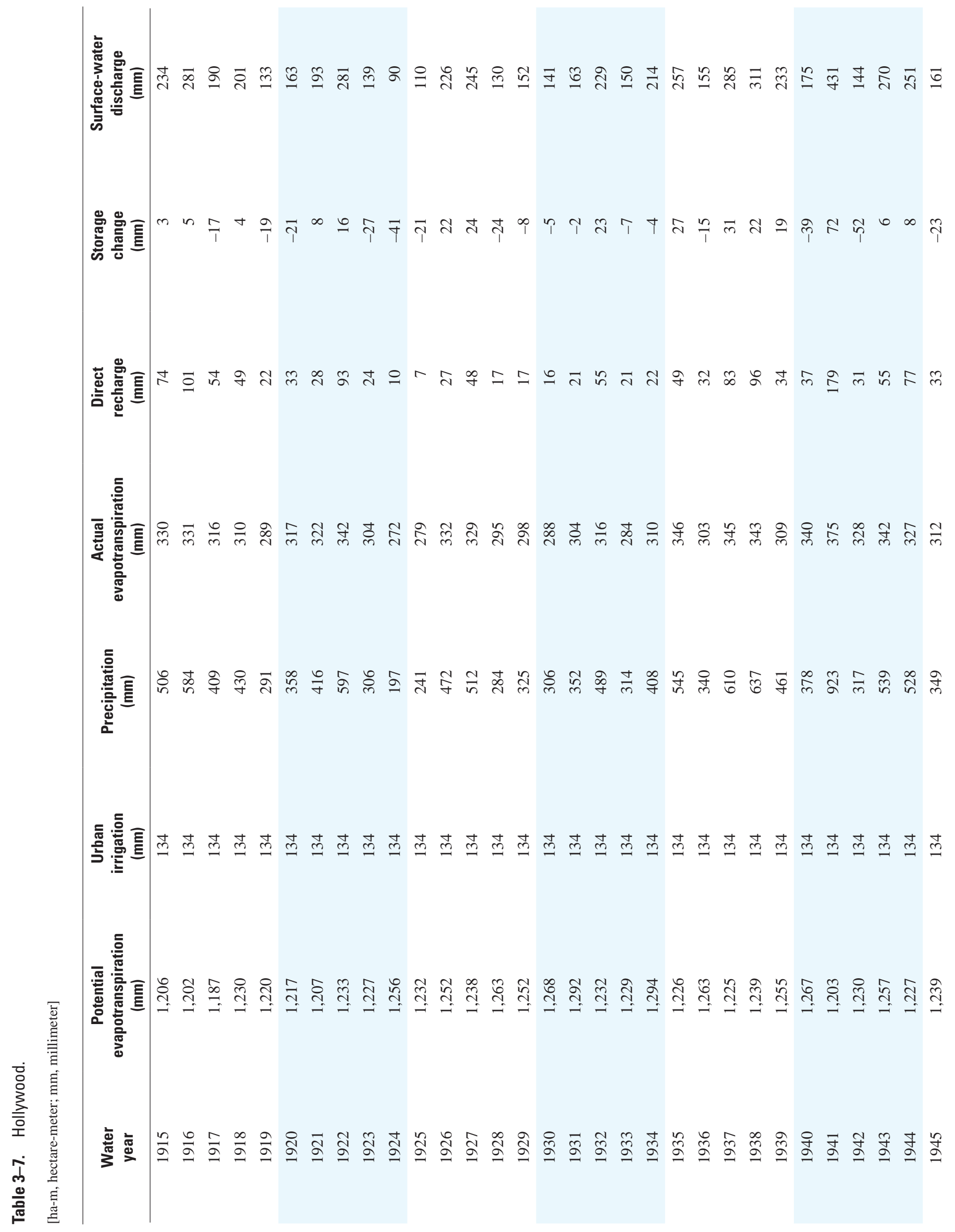




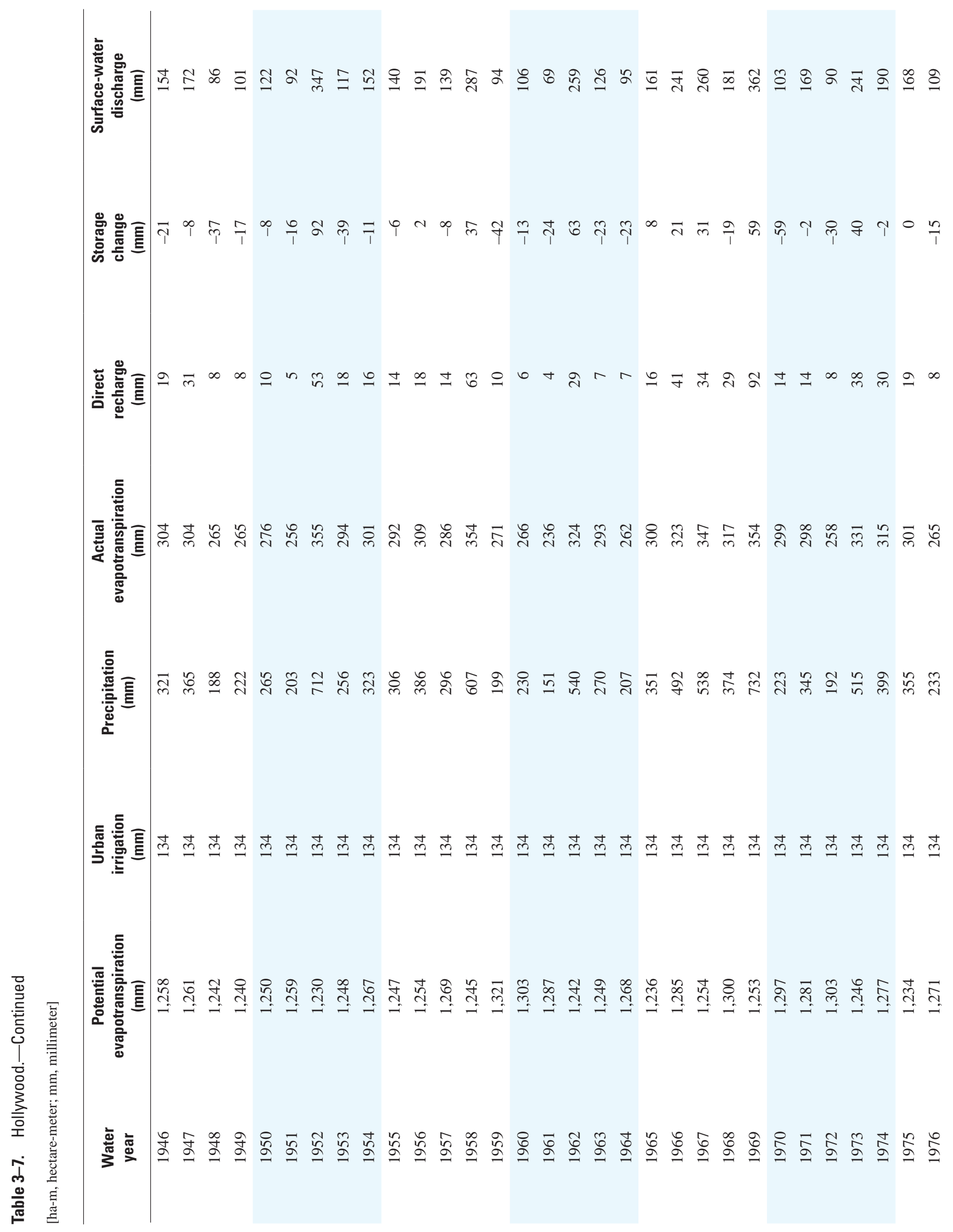




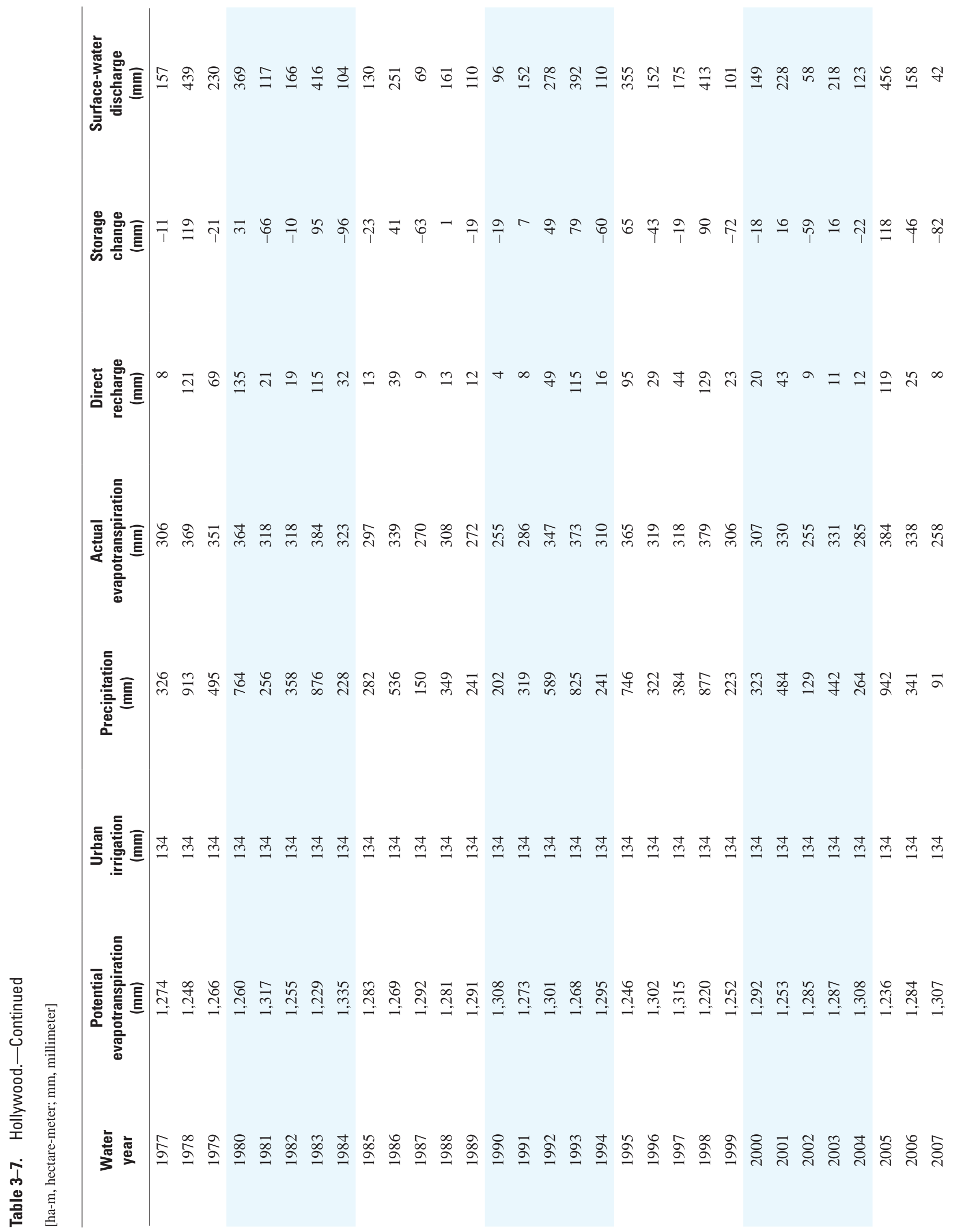




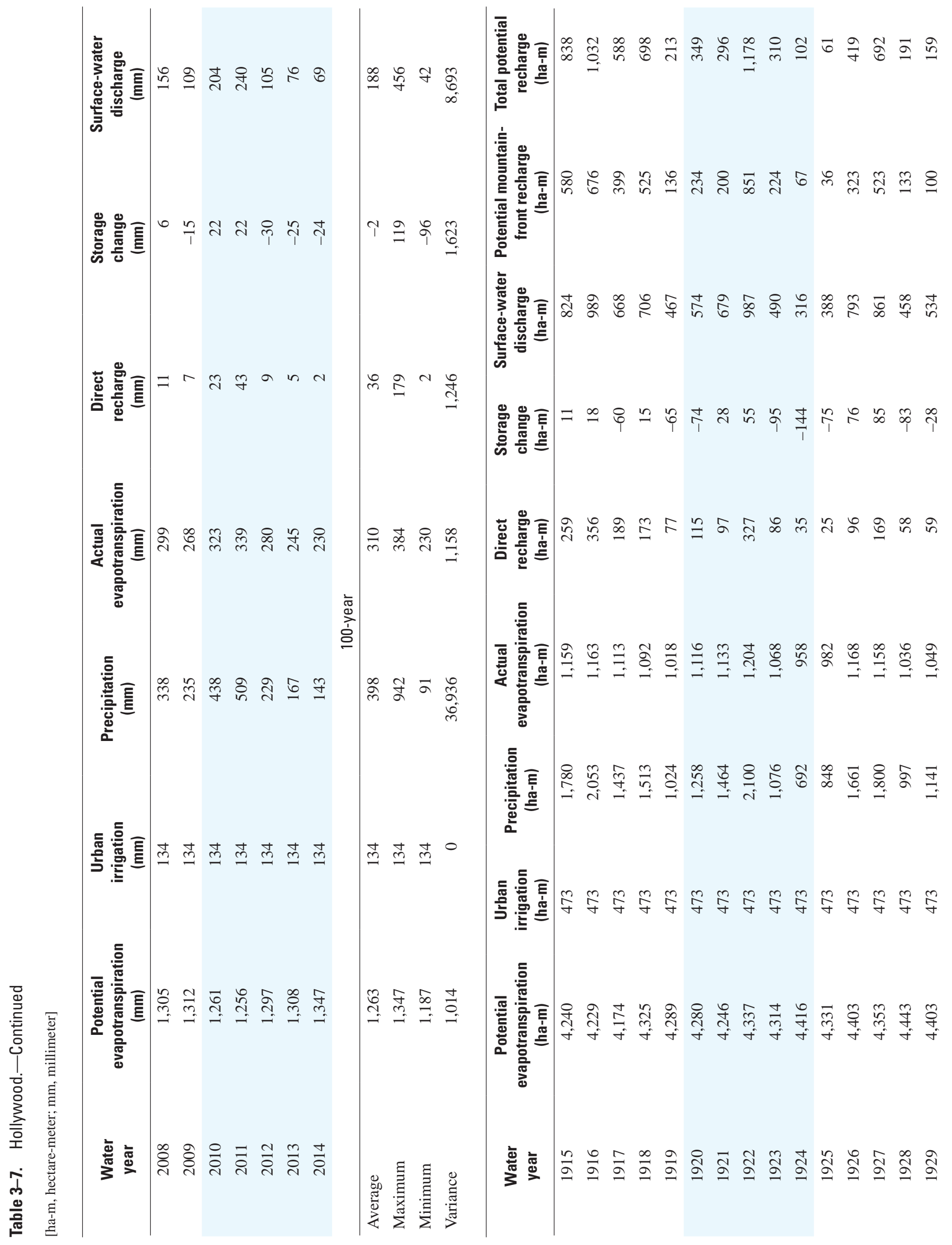




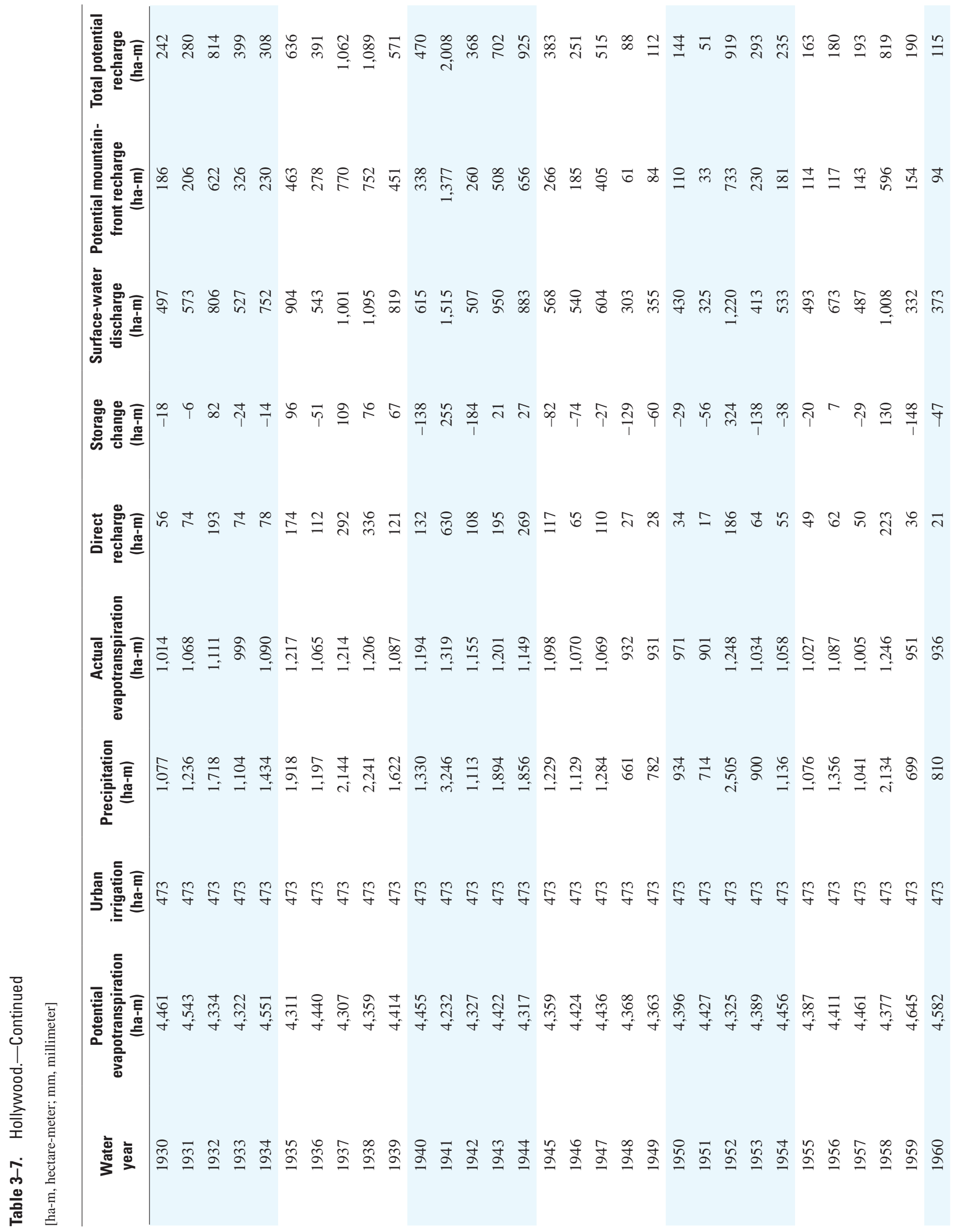




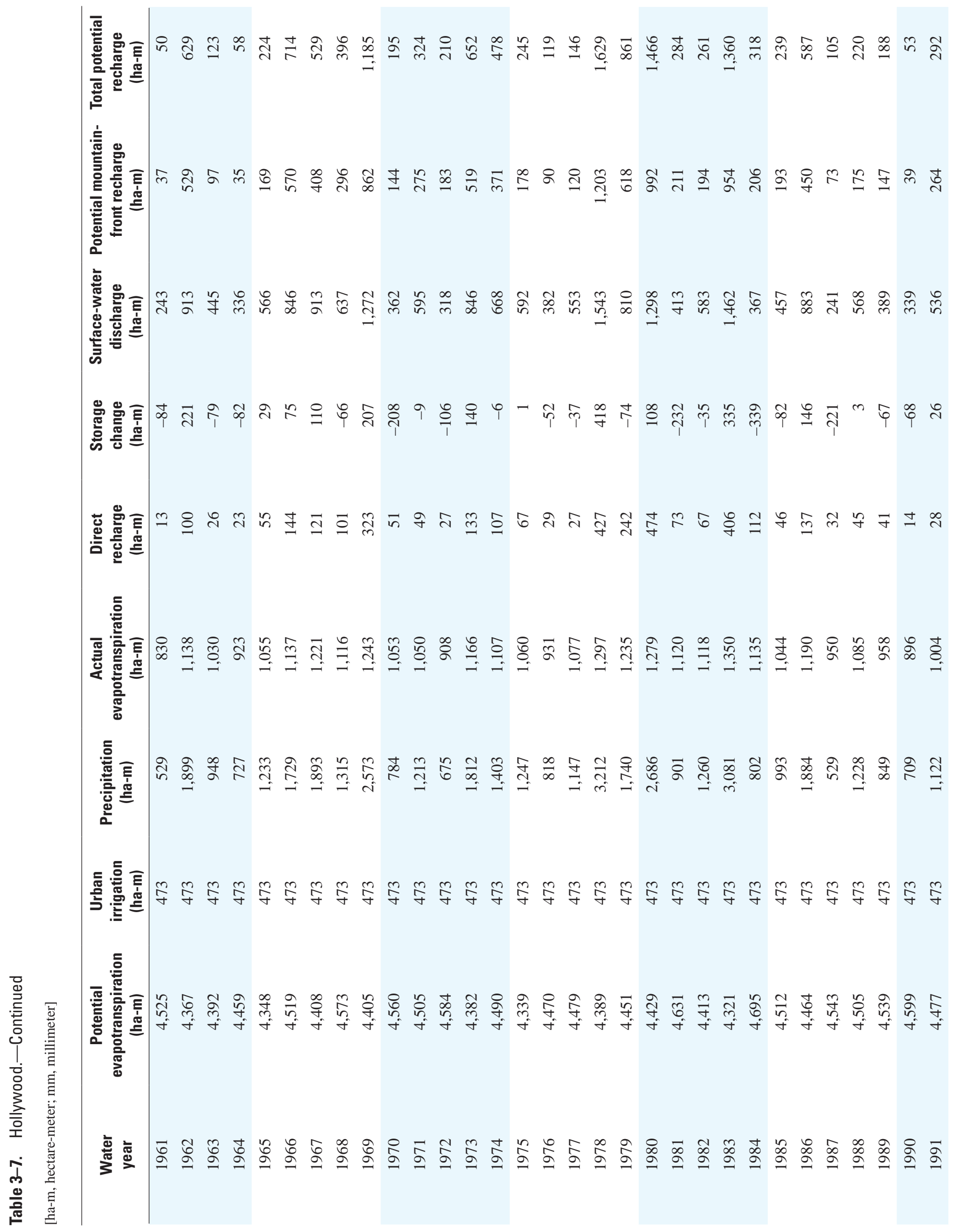




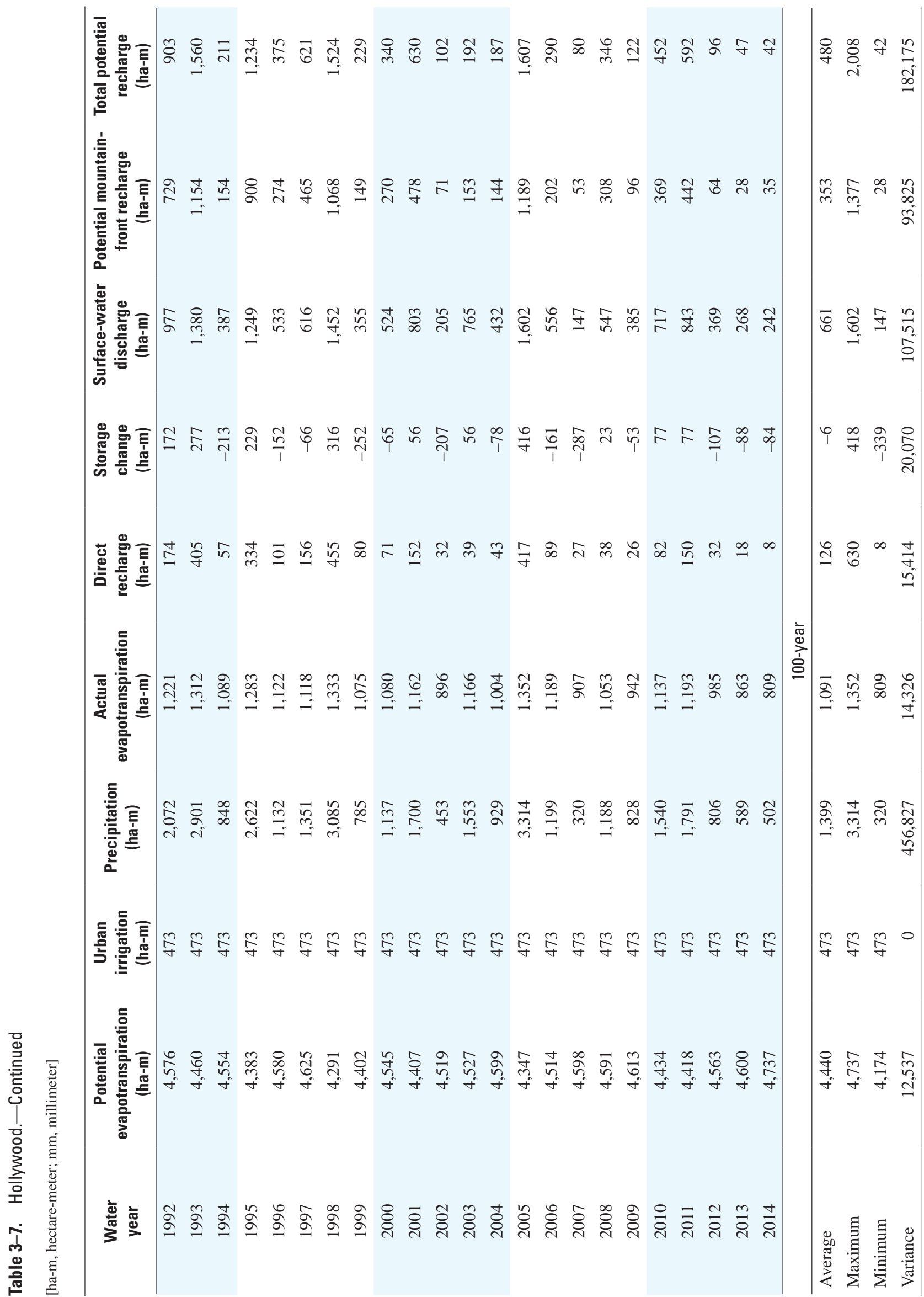




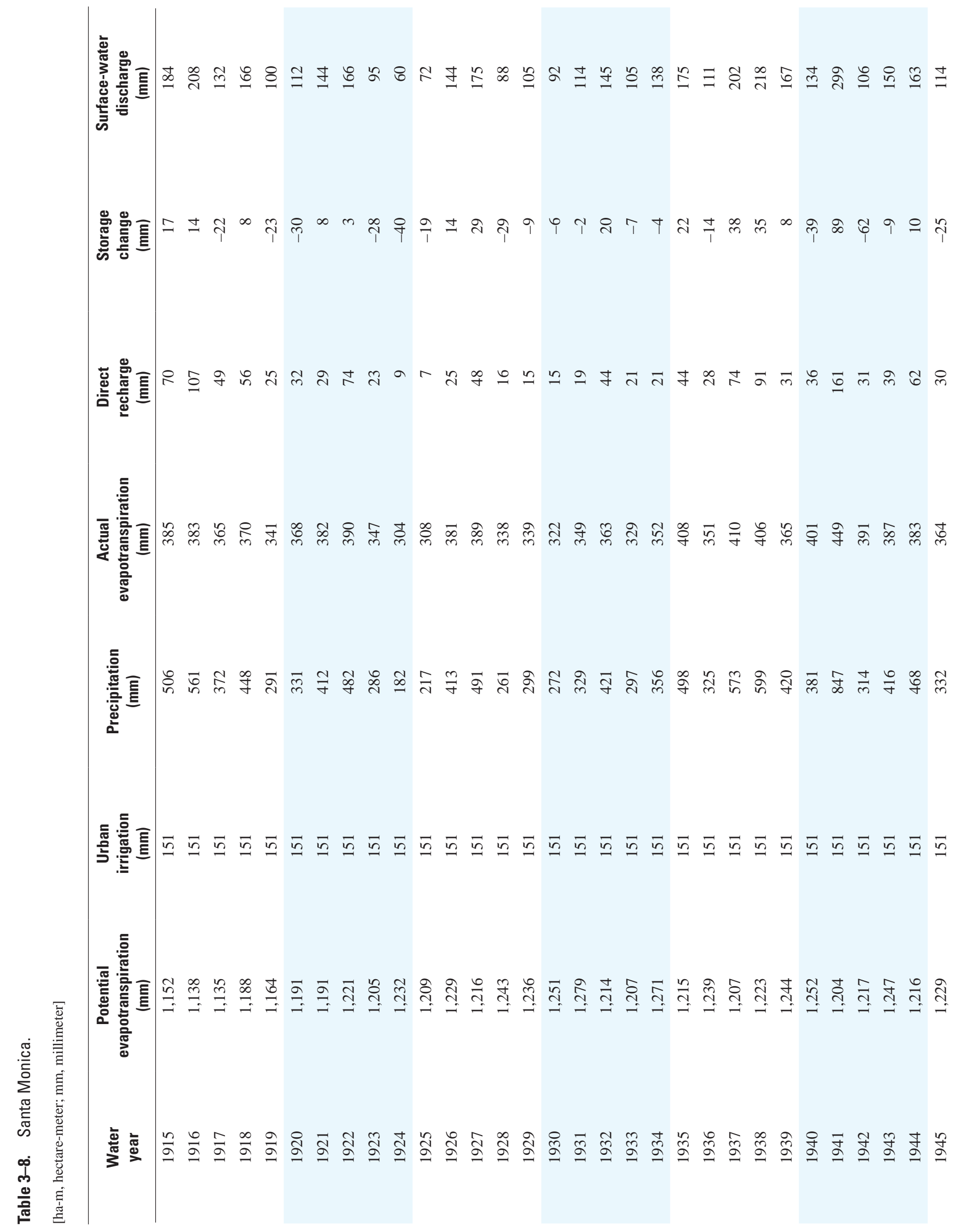




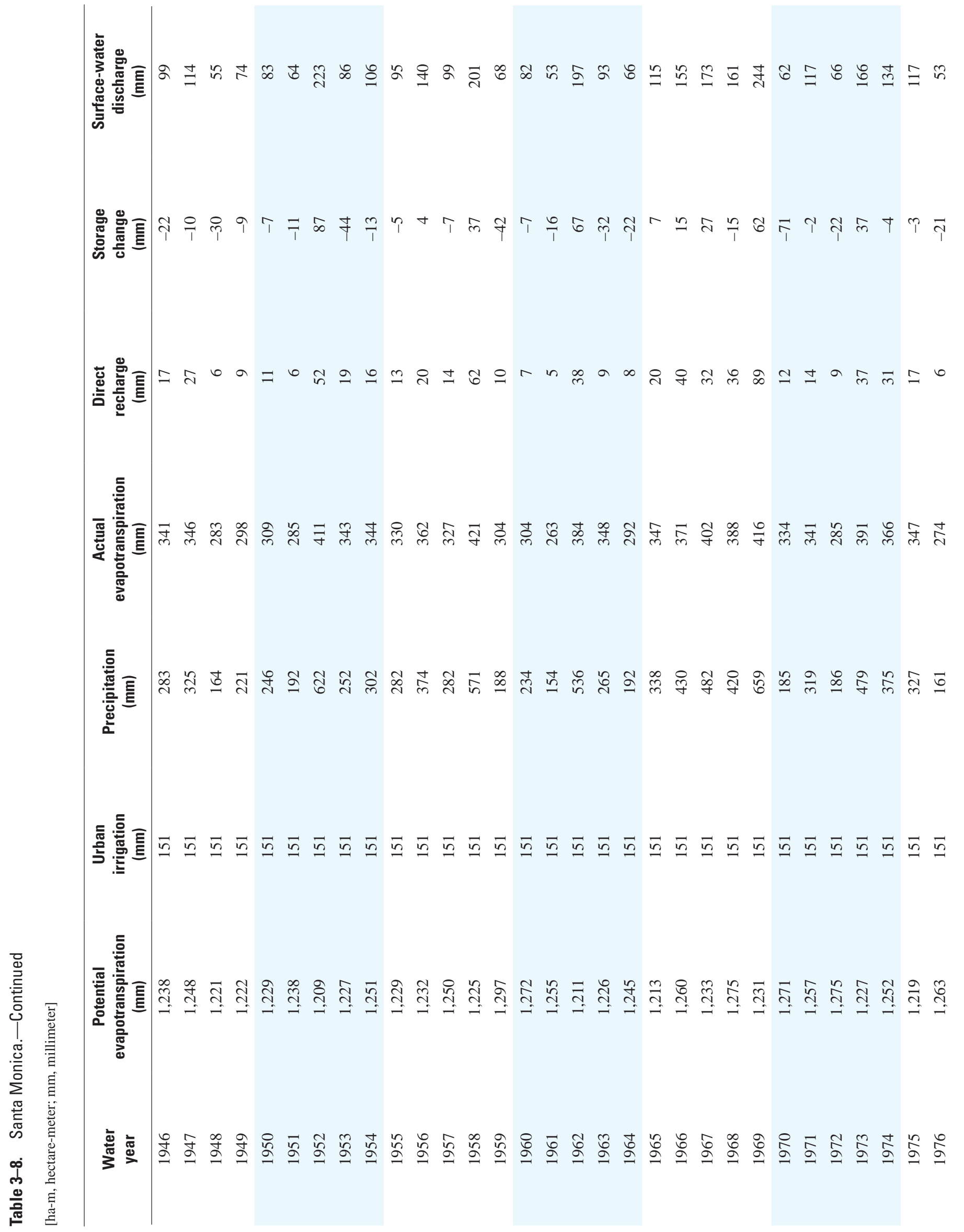




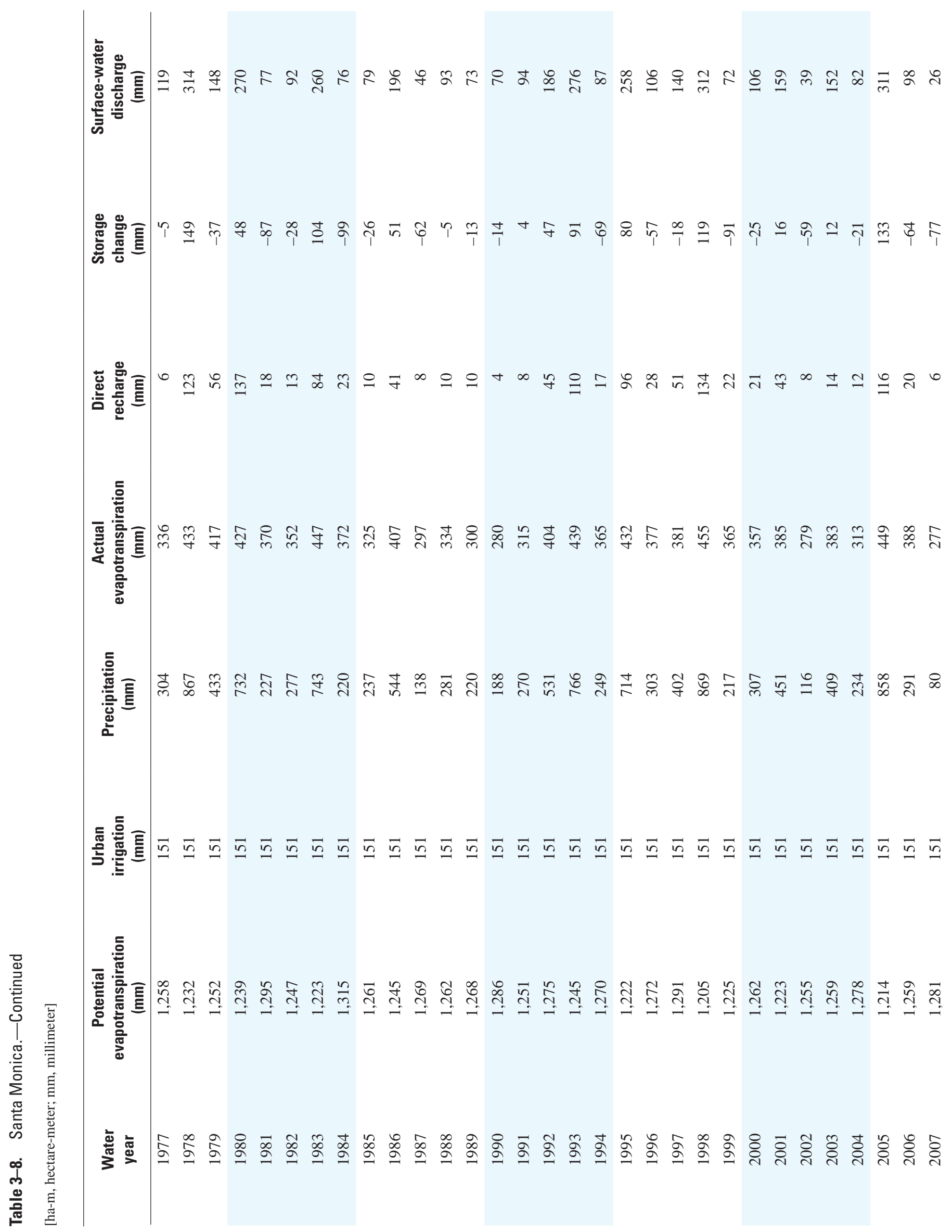




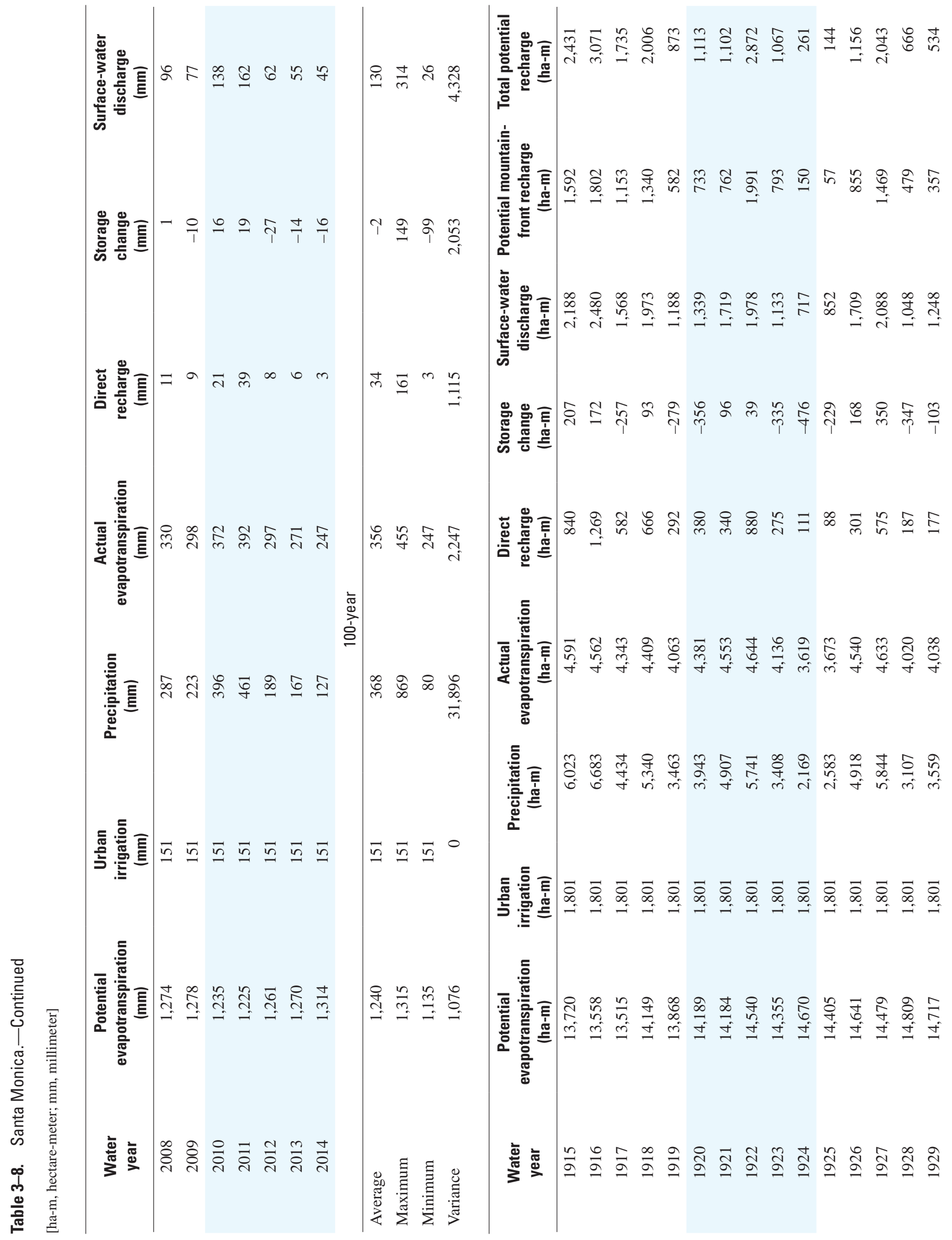




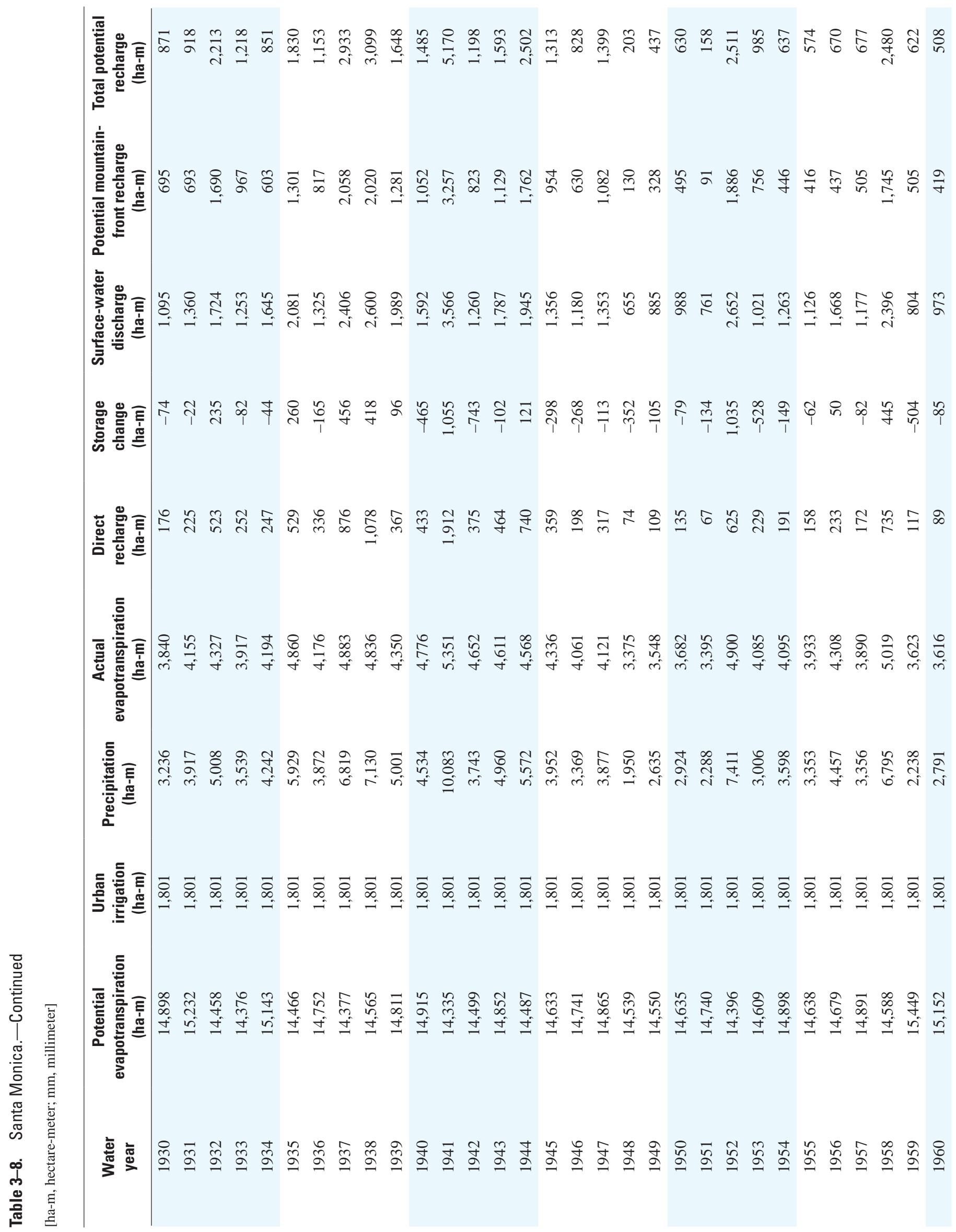




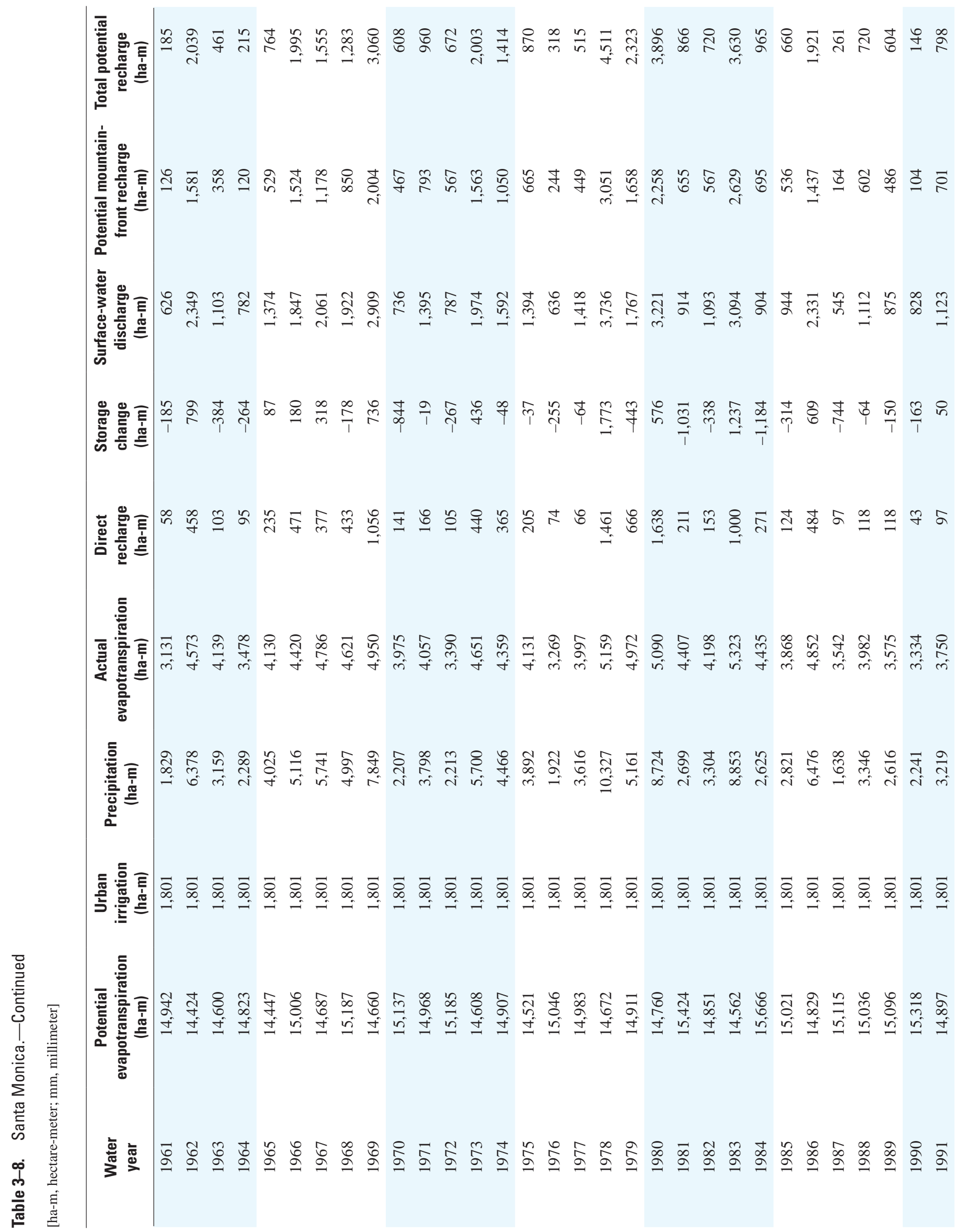




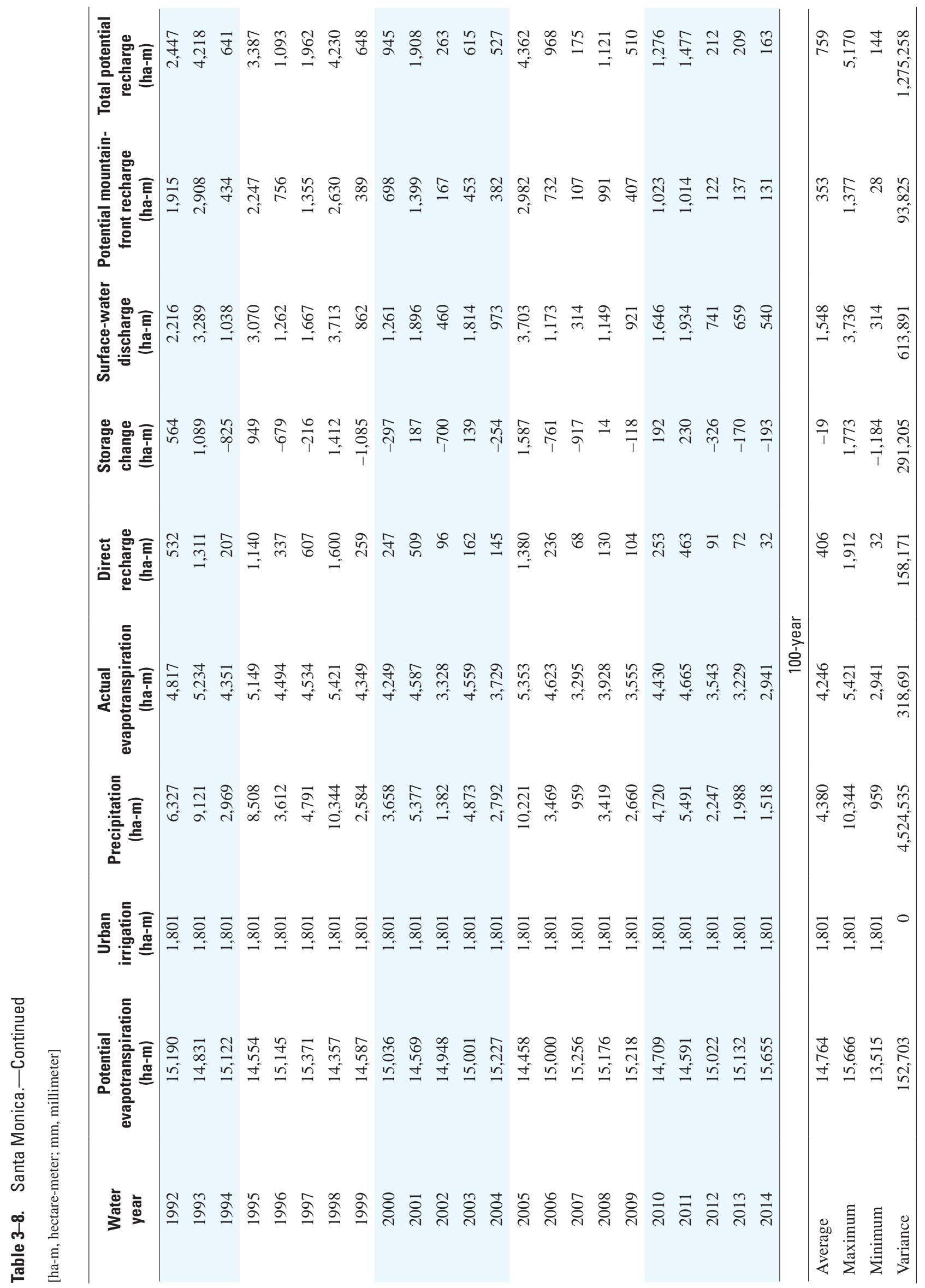




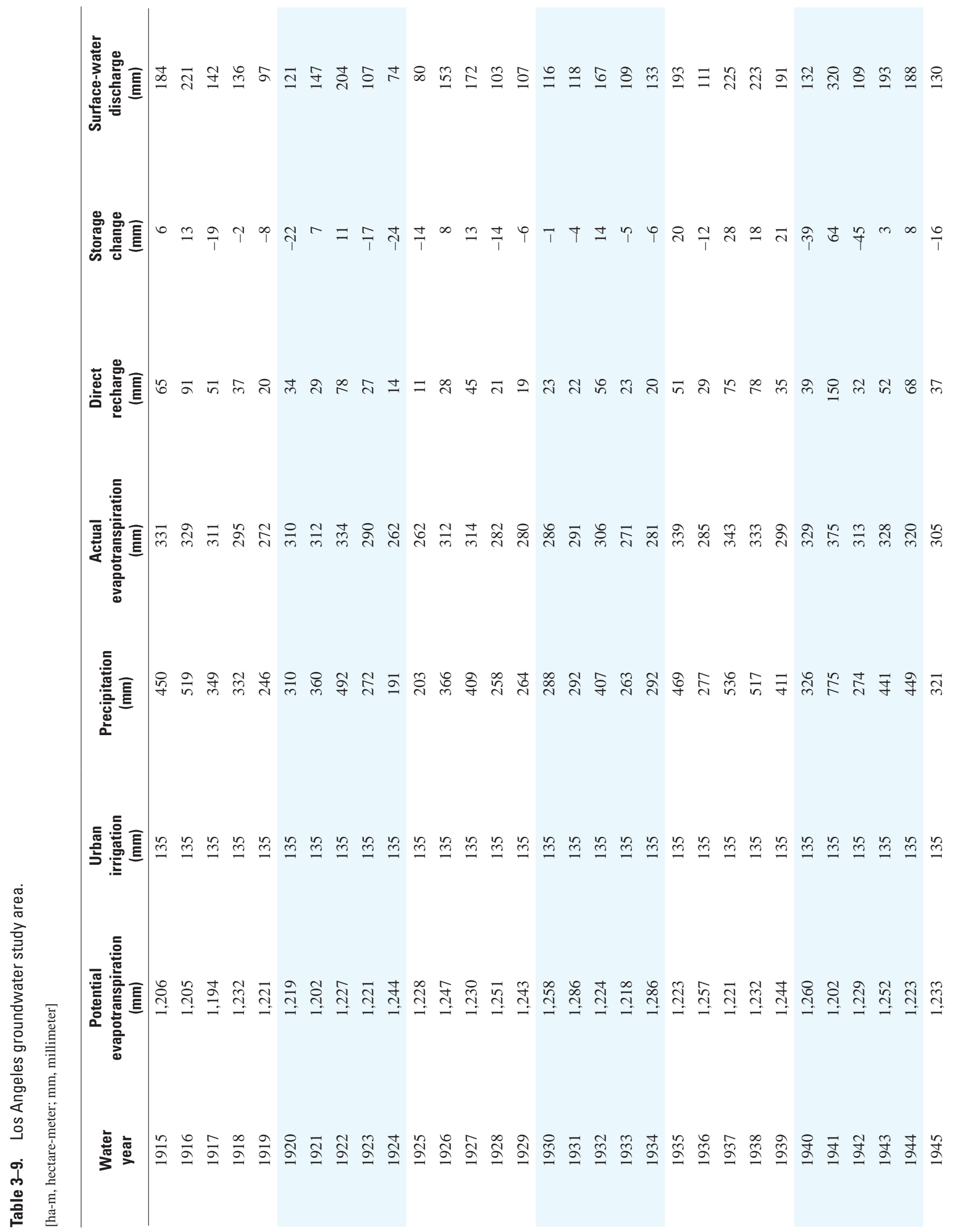




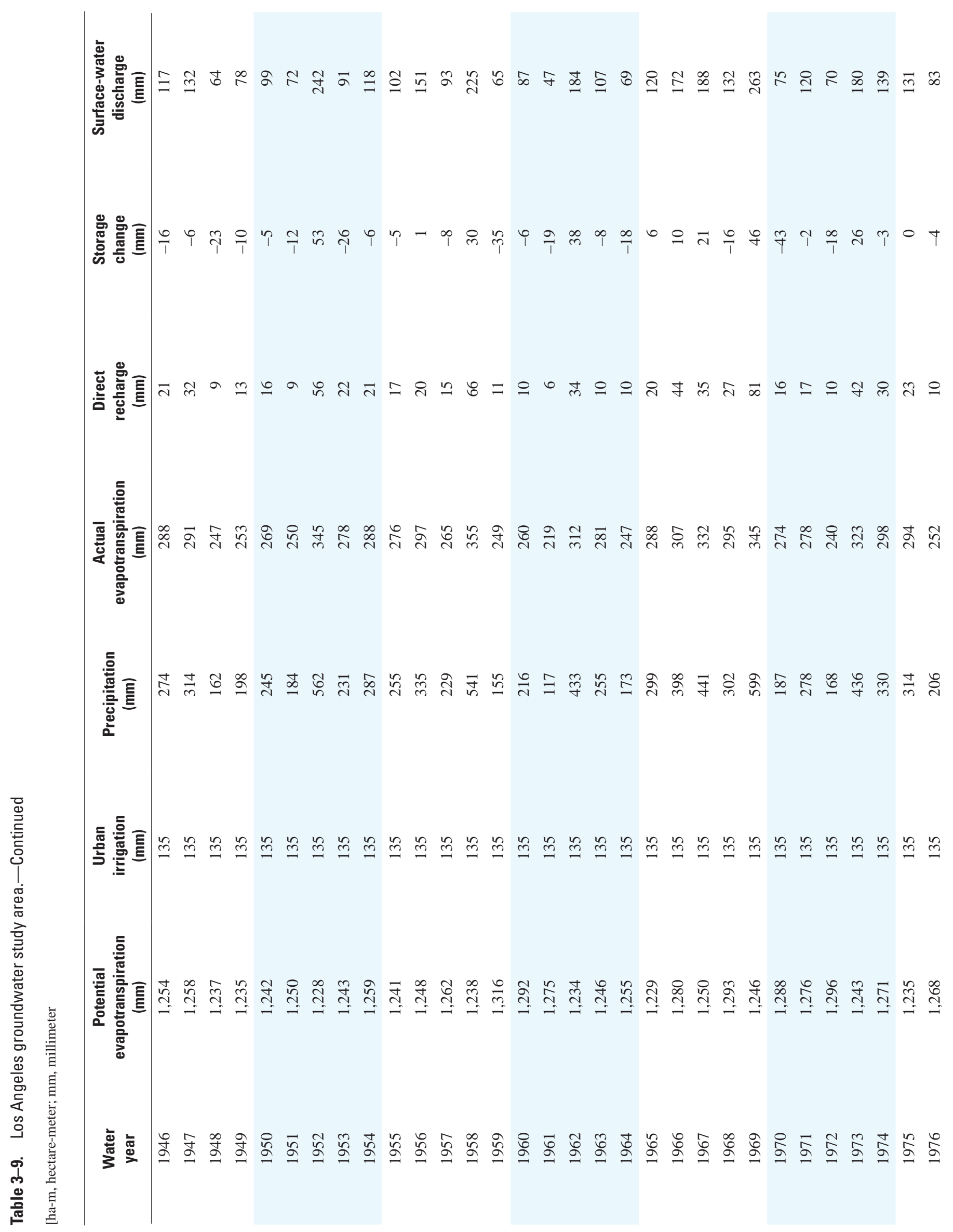




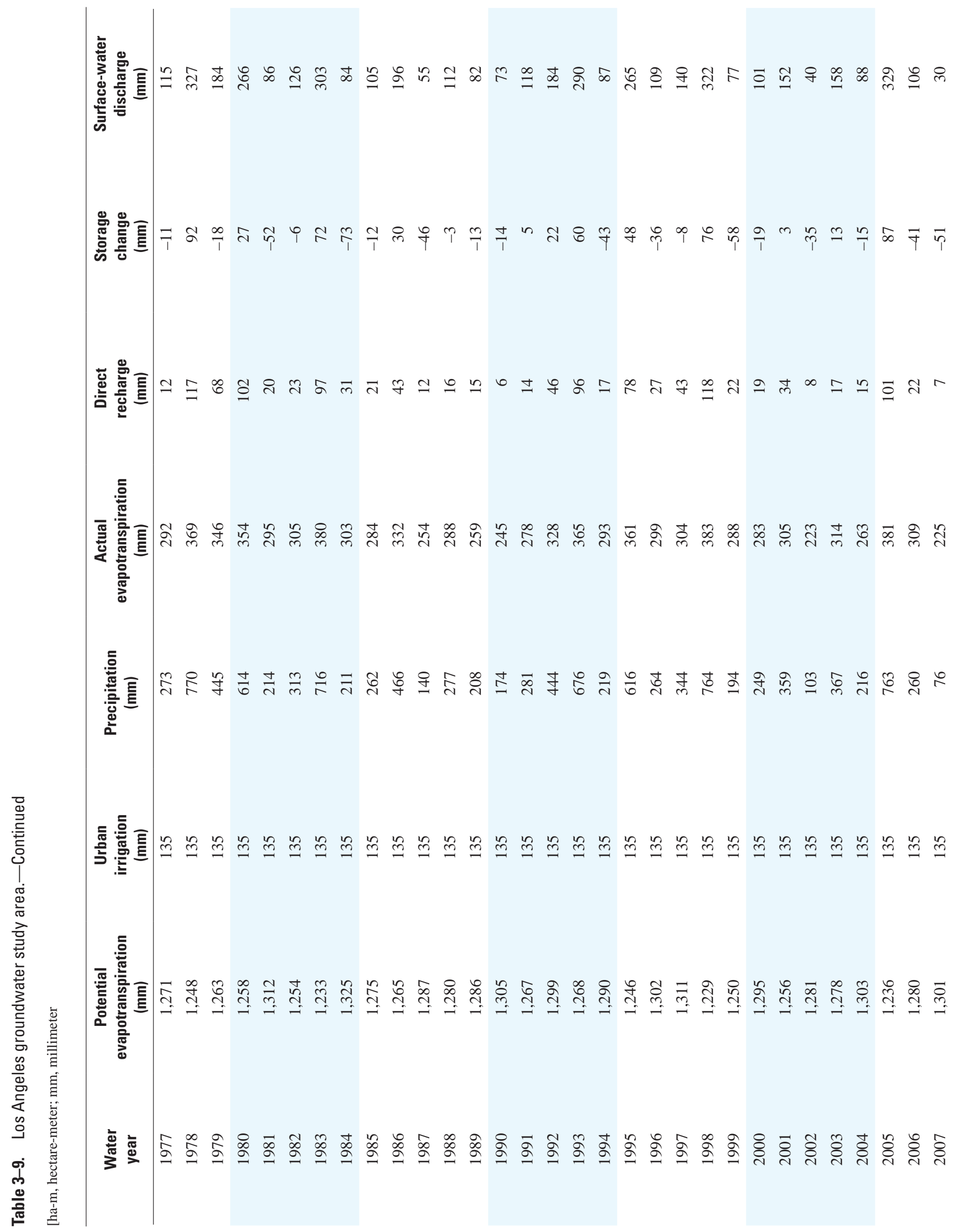




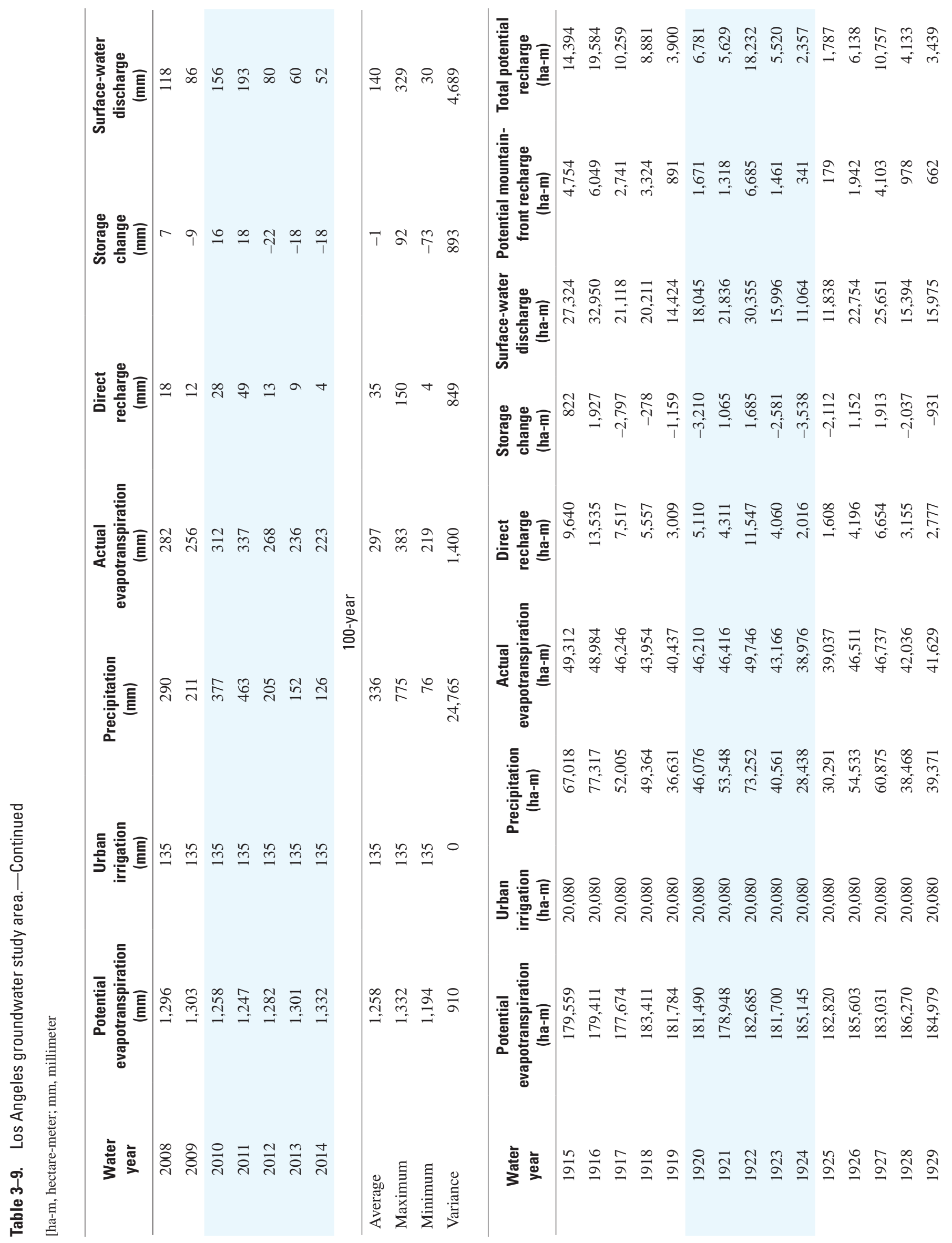




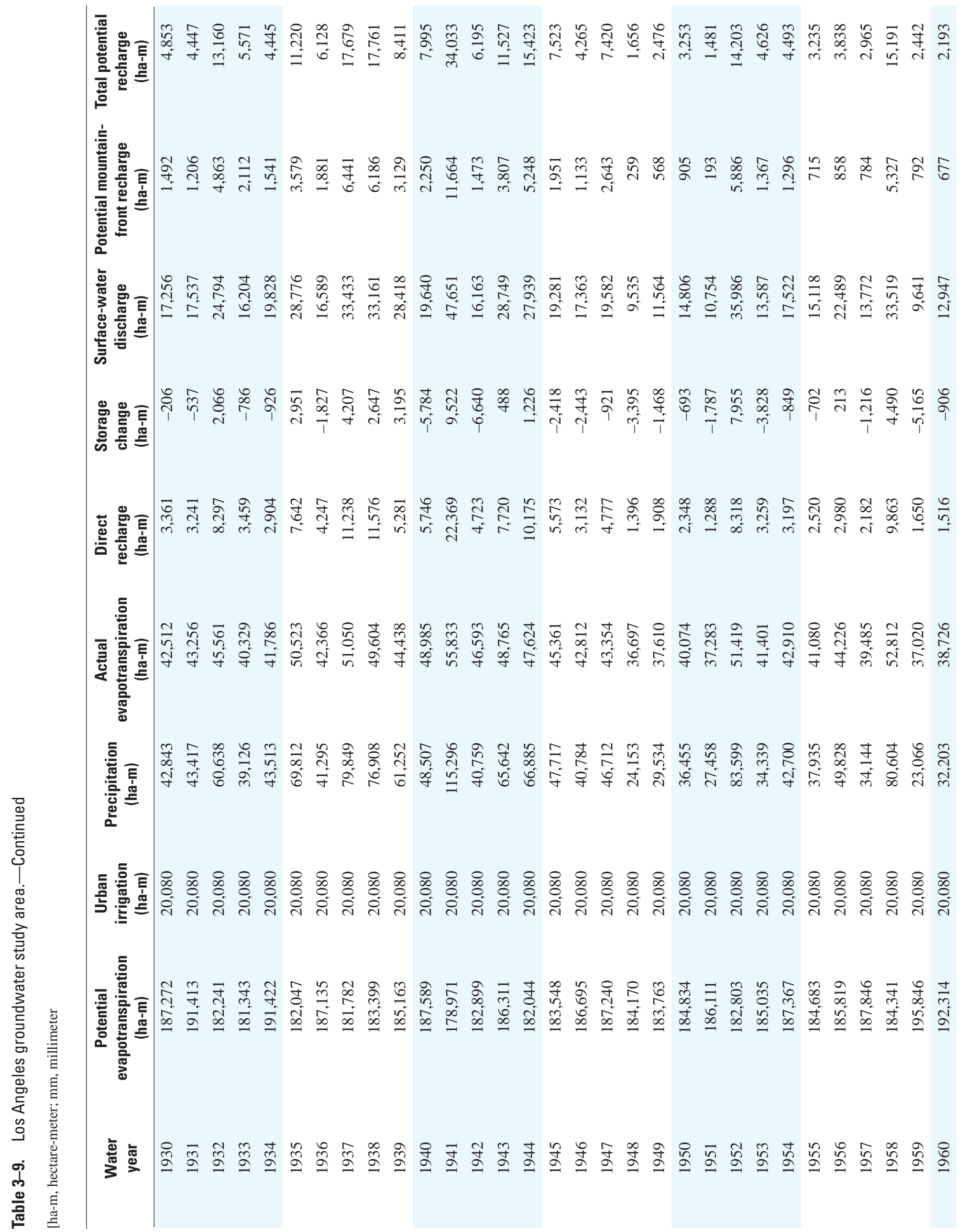




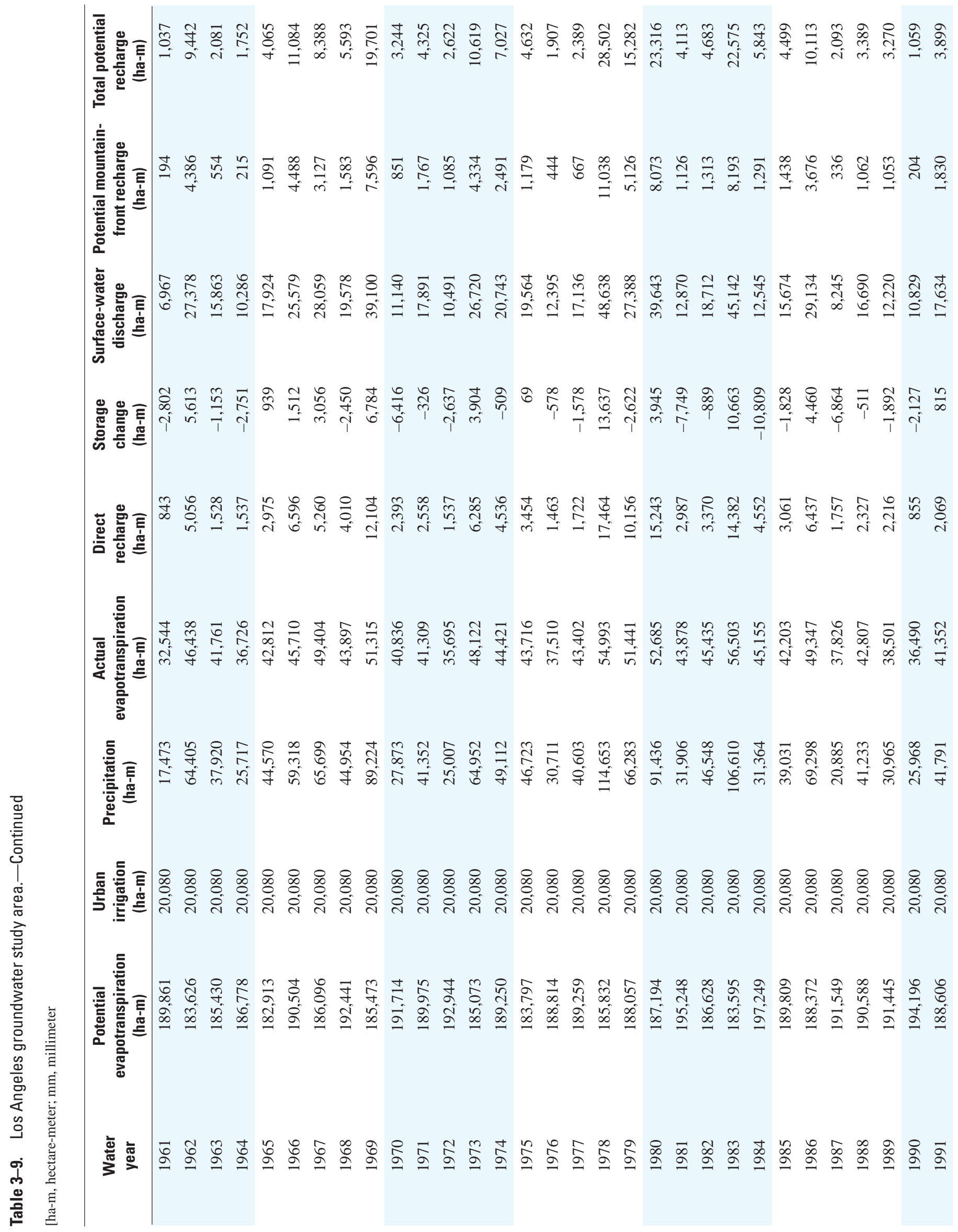




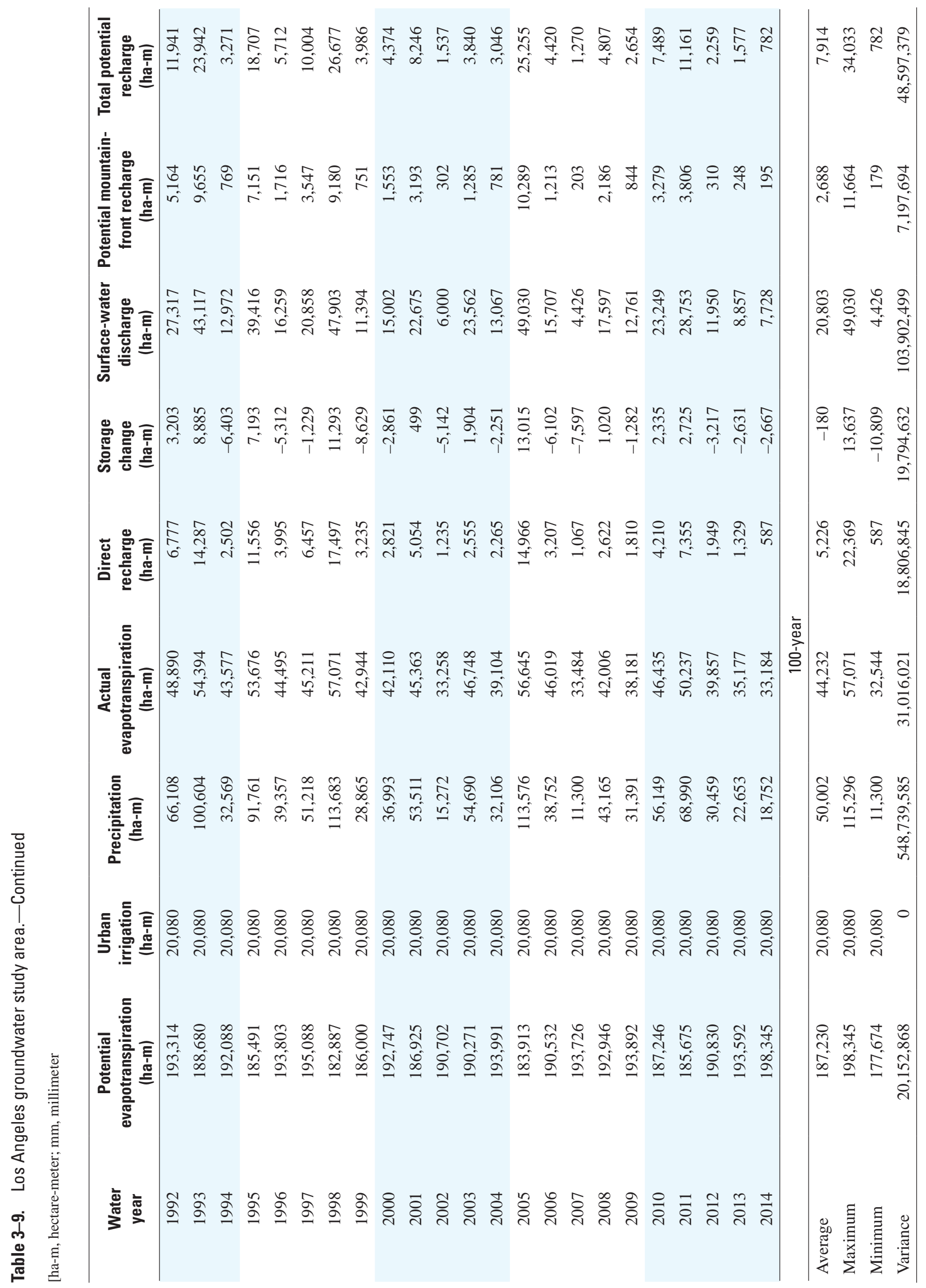


Prepared by the Sacramento Publishing Service Center.

For more information concerning this report, contact:

Director

U.S. Geological Survey

California Water Science Center

6000 J Street, Placer Hall

Sacramento, CA 95819

dc_ca@usgs.gov

or visit our Web site at:

http://ca.water.usgs.gov 
